\title{
Further Indo-West Pacific palaemonoid shrimps (Crustacea: Decapoda: Palaemonoidea), principally from the New Caledonian region
}

\author{
XINZHENG LI $^{1}$ \& ALEXANDER J. BRUCE ${ }^{2}$ \\ ${ }^{1}$ Institute of Oceanology, Chinese Academy of Sciences, Qingdao, China, and ${ }^{2}$ Queensland Museum, \\ South Brisbane, QLD, Australia
}

(Accepted 14 April 2006)

\begin{abstract}
Based on the material deposited in the Muséum national d'Histoire naturelle, Paris, collected from the Indo-West Pacific, principally from the New Caledonian region, the present paper reports 117 palaemonoid shrimp species, which belong, respectively, to Anchistioididae (one genus, one species), Gnathophyllidae (one genus, one species), Palaemonidae Palaemoninae (seven genera, nine species), and Palaemonidae Pontoniinae (30 genera, 106 species), including eight new species. The new species are all Pontoniinae: Mesopontonia brevicarpalis sp. nov., Palaemonella komaii sp. nov., Periclimenes crosnieri sp. nov., Periclimenes forgesi sp. nov., Periclimenes loyautensis sp. nov., Periclimenes paralcocki sp. nov., Periclimenes paraleator sp. nov., and Periclimenes pseudalcocki sp. nov. The last six new species are members of the deep-water "Periclimenes alcocki species complex", which has more than two (usually four) pairs of dorsolateral telson spines anterior to the posterior telson margin, the cornea is usually reduced, the dactyl of the major second chela is generally flanged and the chela is sometimes covered with small tubercles. The complex is usually found at more than $200 \mathrm{~m}$ depth in the West Pacific. The species can be distinguished from each other by the armature of ambulatory propod and dactyl, diameter of cornea, rostrum shape and the number of pairs of dorsolateral telson spines. Mesopontonia brevicarpalis sp. nov., from the southeast coast of Africa, is the seventh species of the genus. Palaemonella komaii sp. nov. is very similar to Palaemonella dolichodactylus Bruce, 1991 and Palaemonella hachijo Okuno, 1999. These three species share the features of very long and slender ambulatory pereiopods with the dactyl more than eight times longer than its basal depth and with several long setae on the dorsal dactylar margin.
\end{abstract}

\section{Résumé}

Basé sur le matériel déposé au Muséum national d'Histoire naturelle, à Paris, récolté dans l'Indoouest Pacifique, principalement dans la région néo-calédonienne, la présente étude porte sur 117 espèces de crevettes Palaemonoidea appartenant respectivement aux familles Anchistioididae (un genre, une espèce), Gnathophyllidae (un genre, une espèce), et Palaemonidae (37 genres et 115 espèces). Chez les Palaemonidae sept genres et neuf espèces appartiennent à la sous-famille Palaemoninae et 30 genres et 106 espèces, donc huit nouvelles, à la sous-famille Pontoniinae. Les espèces sont: Mesopontonia brevicarpalis sp. nov., Palaemonella komaii sp. nov., Periclimenes crosnieri sp. nov., Periclimenes forgesi sp. nov., Periclimenes loyautensis sp. nov., Periclimenes paralcocki sp. nov.,

Correspondence: Xinzheng Li, Institute of Oceanology, Chinese Academy of Sciences, 7 Nanhai Road, Qingdao 266071, China. Email: lixzh@ms.qdio.ac.cn

Published 12 July 2006

ISSN 0022-2933 print/ISSN 1464-5262 online (C) 2006 Taylor \& Francis

DOI: $10.1080 / 00222930600763627$ 
Periclimenes paraleator $\mathrm{sp}$. nov, Periclimenes pseudalcocki $\mathrm{sp}$. nov. Les six dernières appartiennent à ce que l'on peut appeler "le complexe Periclimenes alcocki" donc les espèces ont un telson portant, en avant de son bord postérieur, plus de deux (habituellement quatre) paires d'épines dorsolatérales, une cornée habituellement réduite, la plus grande des pinces des deuxièmes péréiopodes partois couverte de petits tubercules et avec des dactyles généralement munis d'un rebord. Les espèces de ce complexe sont habituellement trouvées à plus de $200 \mathrm{~m}$ de profondeur dans l'Ouest Pacifique. Elles peuvent être séparées les unes des autres par l'armature du propode et du dactyle des pattes ambulatoires, le diamètre de la cornée, le rostre et le nombre des paires d'épines dorsolatérales du telson. Mesopontonia brevicarpalis sp. nov. de la côte sud-est de l'Afrique est la septième espèce du genre, Palaemonella komaii sp. nov. est très semblable à Palaemonella dolichodactylus Bruce, 1991 et Palaemonella hachijo Okuno, 1999; ces trois espèces présentent des peréiopodes ambulatoires très longs et grêles, terminés par un dactyle plus de huit fois plus long que large à sa base et orné de plusieurs longues soies sur son bord dorsal. Si l'on considère les espèces mentionnées par Bruce (1981a, 1985a, 1990a, 1991a, 1991b, 1996) d'après les récoltes faites dans Indo-Ouest Pacifique et déposées au Muséum national d'Histoire naturelle, c'est 169 espèces de crevettes Palaemonoidea appartenant à cinq familles ou sous-familles et 48 genres qui sont actuellement déposés à Paris.

Keywords: Indo-West Pacific, New Caledonia, Palaemonoidea, shrimps, new species

\section{Introduction}

The shrimp material of the superfamily Palaemonoidea deposited principally in the collections of the Muséum national d'Histoire naturelle, Paris, collected mainly from the Indo-Pacific areas, has been reported by Bruce (1981a, 1985a, 1990a, 1991a, 1991b, 1996). The present study, which is a continuation of the series reports of the superfamily, started in 1995 by A. J. Bruce when he visited the museum. X. Li restarted this study when he visited the museum in the fall of 2004. The present paper reports the combined results of this research based on the Indo-Pacific material from the east coast of Africa to southwestern Pacific, but principally from the New Caledonian region, collected by a series of campaigns by the Muséum national d'Histoire naturelle, and the Office de la Recherche Scientifique et Technique Outre-Mer (now Institut de Recherche pour le Developpement).

The names, research vessels, dates and localities of expeditions (campagnes) which produced samples in this study are listed as following:

MD 32: "Marion Dufresne”, 11 August to 10 September 1982, La Réunion.

MUSORSTOM 3: "Coriolis", 31 May to 7 June 1985, Philippines.

BIOCAL: "Jean-Charcot", 9 August to 10 September 1985, New Caledonia (Loyalty Basin and Norfolk Ridge).

KARUBAR: "Baruna Jaya 1", 21 October to 5 November 1991, Indonesia (Kai Islands and Tanimbar).

MUSORSTOM 7: “Alis", 5 May to 4 June 1992, Wallis Islands and Futuna.

BERYX 11: “Alis", 13-23 October 1992, New Caledonia (Norfolk and Loyalty Ridges).

SMIB 8: "Alis", 26 January to 3 February 1993, New Caledonia (Norfolk Ridge).

BATHUS 1: “Alis", 9-20 March 1993, New Caledonia (east coast).

BATHUS 2: "Alis", 10-18 May 1993, New Caledonia (southwest coast).

BATHUS 3: “Alis”, 22 November to 2 December 1993, New Caledonia (south of Loyalty Islands ridge, Norfolk ridge, southwest New Caledonia).

HALIPRO 1: "Alis", 18-25 March and 29 March to 1 April 1994, New Caledonia (east and south coast).

BATHUS 4: "Alis", 1-12 August 1994, New Caledonia (north and west coast).

MUSORSTOM 8: “Alis", 19 September to 14 October 1994, Vanuatu. 
HALIPRO 2: “Tangaroa", 4-28 November 1996, Norfolk Ridge and south Loyalty Ridge. AMUSIUM 1: "Alis”, 5-14 June 1998, Lagoons of Landsdowne and Bellona.

MUSORSTOM 10: “Alis”, 5-19 August 1998, Fiji.

SUVA 2: “Alis", 13-22 October 1998, Fiji (Viti Levu, north and west lagoons).

BORDAU 1: "Alis", 22 February to 14 March 1999, Fiji.

SURPRISES: “Alis”, 12 April to 15 May 1999, New Caledonia (Surprise Atoll, northwest coast of New Caledonia).

LITHIST: “Alis”, 10-12 August 1999, New Caledonia.

SUVA 4: "Alis", 21-26 September 1999, Fiji (Suva Harbour, Lauthana Bay, Beqa Laggon, Pacific Harbour).

BORDAU 2: "Alis", 31 May to 22 June 2000, Tonga.

NORFOLK 1: “Alis”, 19-26 June 2001, Norfolk Ridge.

SALOMON 1: "Alis", 23 September to 7 October 2001, Solomon Islands.

NORFOLK 2: “Alis", 20 October to 6 November 2003, Norflok Ridge.

SALOMON 2: "Alis", 20 October to 8 November 2004, Solomon Islands.

In the following account, carapace length (cl) refers to the postorbital carapace length; the rostral formula is presented as " $a+b / c$ " ( $a=$ the number of dorsal rostral teeth posterior to the orbital margin, $b=$ the number of dorsal rostral teeth anterior to the orbital margin, $\mathrm{c}=$ the number of the ventral rostral teeth) or "b/c" if there is no dorsal rostral tooth on the carapace posterior to the orbital margin; $s t n=$ station. The specimens are all deposited in the collections of the Muséum national d'Histoire naturelle, Paris.

\section{Species list}

(Three families, 39 genera, 117 species.)

Family ANCHISTIOIDIDAE Borradaile, 1915

Anchistioides willeyi (Borradaile, 1899) . . . . . . . . . . . . 616

Family GNATHOPHYLLIDAE Dana, 1852

Gnathophyllum americanum Guérin-Méneville, 1855 . . . . . . . . 617

Family PALAEMONIDAE Rafinesque, 1815

Subfamily PALAEMONINAE Rafinesque, 1815

Brachycarpus biunguiculatus (Lucas, 1846) . . . . . . . . . . . . . 618

Leander tenuicornis (Say, 1818) . . . . . . . . . . . . . . . . . . 618

Macrobrachium australe (Guérin-Méneville, 1838) . . . . . . . . . 619

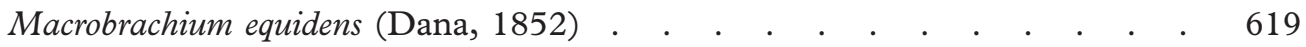

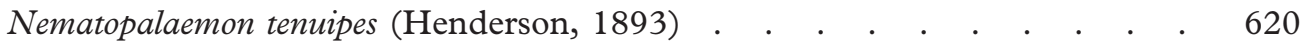

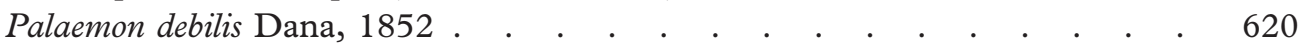

Palaemonetes atrinubes Bray, 1976 . . . . . . . . . . . . . . . 621

Urocaridella antonbruunii (Bruce, 1967) . . . . . . . . . . . . . 621

Urocaridella urocaridella (Holthuis, 1950) . . . . . . . . . . . . 
Subfamily PONTONIINAE Kingsley, 1878

Allopontonia iaini Bruce, 1972

Altopontonia disparostris Bruce, 1990.

Amphipontonia kanak Bruce, 1991 . . . . . . . . . . . . . 625

Anchistus custos (Forskål, 1775) . . . . . . . . . . . . . . . .625

Anchistus miersi (De Man, 1888) . . . . . . . . . . . . . . . 626

Anchistus pectinis Kemp, 1922 . . . . . . . . . . . . . . . . .626

Climeniperaeus truncoideus (Chace and Bruce, 1993) . . . . . . . . . . 627

Conchodytes biunguiculatus (Paulson, 1875) . . . . . . . . . . . . 627

Conchodytes maculatus Bruce, 1989 . . . . . . . . . . . . . . . 628

Conchodytes meleagrinae Peters, 1852 . . . . . . . . . . . . 628

Coralliocaris sp. . . . . . . . . . . . . . . . . . . . . . . . 629

Coralliocaris macrophthalma (H. Milne-Edwards, 1837) . . . . . . . 629

Coralliocaris superba (Dana, 1852) . . . . . . . . . . . . . . . . 630

Coralliocaris viridis Bruce, 1974 . . . . . . . . . . . . . . . 630

Dasycaris ceratops Holthuis, 1952 . . . . . . . . . . . . . . . 631

Dasycaris symbiotes Kemp, 1922 . . . . . . . . . . . . . . 631

Dasycaris zanzibarica Bruce, 1973 . . . . . . . . . . . . . . . 632

Exoclimenella denticulata (Nobili, 1906) . . . . . . . . . . . . . 632

Exoclimenella cf. denticulata (Nobili, 1906) . . . . . . . . . . . . 633

Exoclimenella maldivensis Duris and Bruce, 1995 . . . . . . . . . 633

Hamodactylus boschmai Holthuis, 1952 . . . . . . . . . . . . 634

Hamodactylus noumeae Bruce, 1970 . . . . . . . . . . . . . 634

Hamopontonia corallicola Bruce, 1970 . . . . . . . . . . . . . 635

Harpiliopsis beaupresii (Audouin, 1825) . . . . . . . . . . . . . . 635

Harpiliopsis depressa (Stimpson, 1860) . . . . . . . . . . . . . . . 636

Harpiliopsis spinigera (Ortmann, 1890) . . . . . . . . . . . . . 636

Harpilius lutescens Dana, 1852 . . . . . . . . . . . . . . . . . 637

Ischnopontonia lophos (Barnard, 1962) . . . . . . . . . . . . . . . . 638

Focaste japonica (Ortmann, 1890) . . . . . . . . . . . . . . . . .

Focaste lucina (Nobili, 1901) . . . . . . . . . . . . . . . . . . . 639

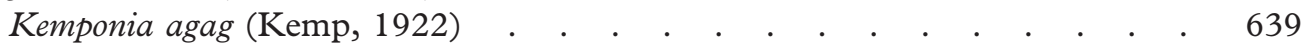

Kemponia amymone (De Man, 1902) . . . . . . . . . . . . . . 641

Kemponia anacanthus (Bruce, 1988) . . . . . . . . . . . . . . . 641

Kemponia andamanensis (Kemp, 1922) . . . . . . . . . . . . . . 642

Kemponia darwiniensis (Bruce, 1987) . . . . . . . . . . . . . . . 643

Kemponia elegans (Paulson, 1875) . . . . . . . . . . . . . . . . .

Kemponia ensifrons (Dana, 1852) . . . . . . . . . . . . . . . 644

Kemponia grandis (Stimpson, 1860) . . . . . . . . . . . . . . . . . .

Kemponia kororensis (Bruce, 1977) . . . . . . . . . . . . . . . . 645

Kemponia lacertae (Bruce, 1992) . . . . . . . . . . . . . . . . . .

Kemponia nilandensis (Borradaile, 1915) . . . . . . . . . . . . . 647

Kemponia seychellensis (Borradaile, 1915) . . . . . . . . . . . . 648

Kemponia cf. suvadivensis (Borradaile, 1915) . . . . . . . . . . . . . . 649

Kemponia tenuipes (Borradaile, 1898) . . . . . . . . . . . . . . . .650

Manipontonia psamathe (De Man, 1902) . . . . . . . . . . . . 651

Mesopontonia brevicarpalis sp. nov. . . . . . . . . . . . . . . 652 
Mesopontonia gracilicarpus Bruce, 1990 .

Metapontonia fungiacola Bruce, 1967

Palaemonella crosnieri Bruce, 1978

Palaemonella dolichodactylus Bruce, 1991

Palaemonella hachijo Okuno, 1999

Palaemonella komaii sp. nov.

Palaemonella pottsi (Borradaile, 1915)

Palaemonella pusilla Bruce, 1975.

Palaemonella rotumana (Borradaile, 1898) . . . . . . . . . . . . . 666

Palaemonella spinulata Yokoya, 1936 . . . . . . . . . . . . . . . . 668

Paraclimenes franklinae (Bruce, 1990) nom. nov. . . . . . . . . 668

Paranchistus nobilii Holthuis, 1952 . . . . . . . . . . . . . 069

Paranchistus ornatus Holthuis, 1952 . . . . . . . . . . . . . . . . 069

Periclimenella petitthouarsi (Audouin, 1825) . . . . . . . . . . 670

Periclimenella spinifera (De Man, 1902) . . . . . . . . . . . . . . 670

Periclimenes affinis (Zehntner, 1894) . . . . . . . . . . . . . 671

Periclimenes alcocki Kemp, 1922 . . . . . . . . . . . . . . 672

Periclimenes aleator Bruce, 1991 . . . . . . . . . . . . . . . . 673

Periclimenes amboinensis (De Man, 1888) . . . . . . . . . . . . . . 674

Periclimenes attenuatus Bruce, 1971 . . . . . . . . . . . . . 675

Periclimenes brevicarpalis (Schenkel, 1902) . . . . . . . . . . . . 676

Periclimenes brevirostris Bruce, 1991 . . . . . . . . . . . . . . . 677

Periclimenes calcaratus Chace and Bruce, 1993. . . . . . . . . . . 677

Periclimenes ceratophthalmus Borradaile, 1915 . . . . . . . . . . . 679

Periclimenes commensalis Borradaile, 1915 . . . . . . . . . . . 679

Periclimenes cristimanus Bruce, 1965 . . . . . . . . . . . . . 680

Periclimenes crosnieri sp. nov. . . . . . . . . . . . . . . . . 681

Periclimenes forcipulatus Bruce, 1991 . . . . . . . . . . . . . . . . 686

Periclimenes forgesi sp. nov. . . . . . . . . . . . . . . . . . 686

Periclimenes foveolatus Bruce, 1981 . . . . . . . . . . . . . . 691

Periclimenes hertwigi Balss, 1913 . . . . . . . . . . . . . . . 692

Periclimenes imperator Bruce, 1967 . . . . . . . . . . . . . . . . . 694

Periclimenes incertus Borradaile, 1915 . . . . . . . . . . . . . . . 695

Periclimenes involens Bruce, 1996..$\quad$.

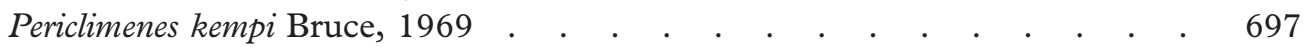

Periclimenes laccadivensis (Alcock and Anderson, 1884) . . . . . . . . . 697

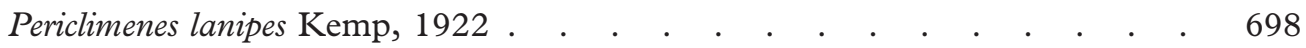

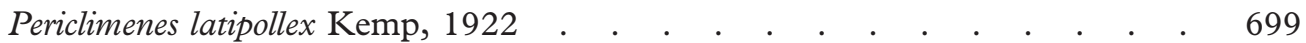

Periclimenes lepidus Bruce, 1978 . . . . . . . . . . . . . . . . 699

Periclimenes loyautensis sp. nov. . . . . . . . . . . . . . . . 700

Periclimenes macrophthalmus Fujino and Miyake, 1970 . . . . . . . 703

Periclimenes magnificus Bruce, 1979 . . . . . . . . . . . . . 705

Periclimenes novaecaledoniae Bruce, 1967 . . . . . . . . . . . 706

Periclimenes paralcocki sp. nov. . . . . . . . . . . . . . 707

Periclimenes paraleator sp. nov. . . . . . . . . . . . . . 711

Periclimenes pilipes Bruce and Zmarzley, 1983 . . . . . . . . . . 715

Periclimenes platyrhynchus Bruce, 1991 . . . . . . . . . . . . 716

Periclimenes pseudalcocki sp. nov. . . . . . . . . . . . . . . 716 
Periclimenes soror Nobili, 1904 . . . . . . . . . . . . . . . 721

Periclimenes tosaensis Kubo 1951 . . . . . . . . . . . . . . . . 721

Periclimenes uniunguiculatus Bruce, 1990 . . . . . . . . . . . 722

Periclimenes vaubani Bruce, 1990. . . . . . . . . . . . . . 722

Periclimenes venustus Bruce, 1990 . . . . . . . . . . . . . . 723

Periclimenes sp. . . . . . . . . . . . . . . . . . . . . . . 723

Philarius imperialis (Kubo, 1940) . . . . . . . . . . . . . . 725

Platycaris latirostris Holthuis, 1952 . . . . . . . . . . . . . 726

Pliopontonia furtiva Bruce, 1973 . . . . . . . . . . . . . . . 726

Pontoniopsis comanthi Borradaile, 1915 . . . . . . . . . . . . 727

Thaumastocaris streptopus Kemp, 1922 . . . . . . . . . . . . 727

Zenopontonia noverca $(\mathrm{Kemp}, 1922)$. . . . . . . . . . . . . 728

\section{Systematic account}

Family ANCHISTIOIDIDAE Borradaile, 1915

Anchistioides willeyi (Borradaile, 1899)

Palaemonopsis willeyi Borradaile 1899, p 410, Plates 36, 37, Figure 7.

Amphipalaemon willeyi: Borradaile 1917, p 407, Plate 59, Figure 13.

Anchistioides willeyi: Gordon 1935, p 344, 345, Figures 23a, 24a; Holthuis 1952a, p 18, 214-219, Figures 106, 107 (partim); Bruce 1990a, p 211; Bruce 1991a, p 400, Figure 70; Bruce 1991b, p 269, Figures 3g, 29, 30; Bruce 1996, p 261.

\section{Material examined}

Comoro Islands: (i) Mayotte, lagoon, dredge, 55 m, coll. A. Crosnier, September 1959, 1 ovig. \& (MNHN-Na 141804). Madagascar: (ii) Pracel Bank, west coast, $55 \mathrm{~m}$, sand, trawl, coll. A. Crosnier, June 1959, 1 ( (MNHN-Na 14805); (iii) Nosy Be, shallow water, coll. A. Crosnier, 1966, 1 ( (MNHN-Na 15965); (iv) $13^{\circ} 40.3^{\prime} \mathrm{S}, 47^{\circ} 48.0^{\prime} \mathrm{E}, 32 \mathrm{~m}$, sand, trawl, coll. A. Crosnier, 5 December 1972, 1 juvenile (MNHN-Na 14803). Philippines: (v) MUSORSTOM 2, stn CP8, $13^{\circ} 55^{\prime} \mathrm{N}, 120^{\circ} 20^{\prime} \mathrm{E}, 85-90$ m, 21 November 1980, 2o̊, 2 juveniles (MNHN-Na 14802). New Caledonia: (vi) lagoon, Five Miles Channel, scuba, 15-20 m, in sponge, coll. C. Vadon, 20 September 1978, 1 ovig. @ (MNHN-Na 15849); (vii) BATHUS 1, stn CP680, 20 48' S, $165^{\circ} 18^{\prime} \mathrm{E}, 86-92 \mathrm{~m}, 15$ March 1993, 1 q (MNHN$\mathrm{Na}$ 14801); (viii) Nouville, washings from eunicid tubes, 18-20 m, coll. P. Bouchet, 1 April

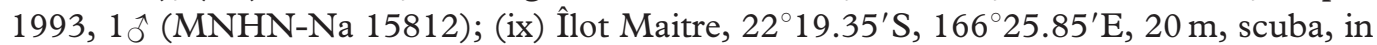
sponge, coll. I. Takeuchi, 10 November 1995, $1 \sigma^{\widehat{T}}$ (MNHN-Na 15808); (x) Îlot Maitre, stn $82,22^{\circ} 19.61^{\prime} \mathrm{S}, 166^{\circ} 24.07^{\prime} \mathrm{E}, 10 \mathrm{~m}$, coll. I. Takeuchi, 14 November $1995,1{ }^{\wedge}(\mathrm{MNHN}-$ $\mathrm{Na}$ 15844); (xi) Surprise Atoll, North New Caledonia, stn CP 1378, $18^{\circ} 26.3^{\prime} \mathrm{S}$,

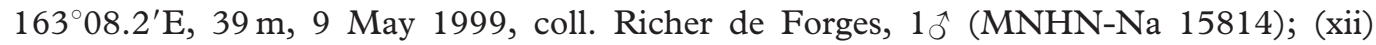
Sarcelle Channel, 30-45 m, in boulders, 1 ovig. \& (MNHN-Na 14800). Fiji: (xiii) MUSORSTOM 10, south of Viti Levu, stn CP 1364, $18^{\circ} 11.9^{\prime} \mathrm{S}, 178^{\circ} 34.5^{\prime} \mathrm{E}, 80-86 \mathrm{~m}, 15$ August 1998, 2o̊ (MNHN-Na 15547); (xiv) SUVA 2, Viti Levu, South Lagoon, stn BS $18,18^{\circ} 11.4^{\prime} \mathrm{S}, 178^{\circ} 28.2^{\prime} \mathrm{E}, 83 \mathrm{~m}, 15$ October 1998, 1 ovig. ${ }^{\circ}$ (MNHN-Na 15546); (xv) SUVA 4, Viti Levu, Bequ Lagoon, stn DW 07, 28-32 m, $18^{\circ} 22.1^{\prime} \mathrm{S}, 178^{\circ} 02.5^{\prime} \mathrm{E}, 24$ September 1999, 1ðَ (MNHN-Na 15545). 


\section{Remarks}

Specimens (iv)-(vii) are of the long-fingered second pereiopod type, (ix) with short fingers and in (ii) the fingers are subequal to the palm. The specimens (viii) may have been derived from sand-burrowing sponges rather than the eunicid tubes as this species is normally associated with sponges.

\section{Distribution}

Type locality: Ralun, New Britain. Also known from Kenya, Zanzibar, Tanzania, Madagascar, Seychelles, Maldives, Singapore, South China Sea, Philippines, Indonesia (Borneo Bank), Australia (Northern Territory, Queensland), and New Caledonia.

Family GNATHOPHYLLIDAE Dana, 1852

Gnathophyllum americanum Guérin-Méneville, 1855

Gnathophyllum americanum Guérin-Méneville 1855, p viii, Plate 2, Figure 14; Chace and Bruce 1993, p 136; Li 1997, p 226, Figure 2; Davie 2002, p 250.

\section{Material examined}

Philippines: MUSORSTOM II, shore station, (i) stn 12, opposite Mactan Marine Station, high tide, late afternoon, 0.2-2 m, 9 December 1980, 1 ovig. ㅇ (MNHN-Na 15913); (ii) island opposite Mactan Marine Station, reef flat, 2 oq (ovig.) (MNHN-Na 15914). New Caledonia: (iii) lagoon, reef, Poindimié, north of Tié, associated with anemone, 1 ovig. @ (MNHN-Na 14832). Loyalty Islands: (iv) ATELIER LIFOU, Lifou, Santal Bay: Easo, near wharf, stn $1406,20^{\circ} 46.85^{\prime} \mathrm{S}, 167^{\circ} 07.75^{\prime} \mathrm{E}$, intertidal, hard substrate, 10/13-14/16/18 November 2000, 1 ovig. ( $(M N H N-N a 15544)$.

\section{Parasites}

(ii) Bopyrid in branchiae chamber of non-ovigerous female.

\section{Remarks}

Not previously recorded from Loyalty Islands. The association with a sea anemone (iii) may have been accidental.

\section{Distribution}

Type locality: Cuba. Also known from Red Sea to South Africa, Mauritius, and eastward through Indo-Pacific region to South China Sea (Xisha Islands), Australia (Queensland, New South Wales, Tasman Sea), Loyalty Islands, French Polynesia (Tuamotu Islands, Tahiti, Rikitea); western Atlantic from Bermuda and southern Florida throughout Gulf of Mexico and Caribbean Sea; eastern Atlantic in Canary Islands. 
Family PALAEMONIDAE Rafinesque, 1815

Subfamily PALAEMONINAE Rafinesque, 1815

Brachycarpus biunguiculatus (Lucas, 1846)

Palaemon biunguiculatus Lucas 1846, p 45, Plate 4, Figure 4.

Brachycarpus biunguiculatus: Kemp 1925, p 312-314; Holthuis 1952b, p 3-10, Plate 1,

Figures a-q; Fransen 1987, p 509, Figure 5; Bruce 1996, p 200, Figures 1a-c, 28a, 30.

\section{Material examined}

La Réunion: (i) $\mathrm{MD} 32$, stn CP97, $19^{\circ} 41.4^{\prime} \mathrm{S}, 54^{\circ} 08.7^{\prime} \mathrm{E}, 55 \mathrm{~m}$, pebbles, large slabs of

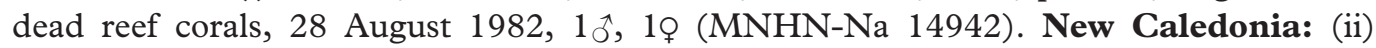
MONTROUZIER, Touho (Tié), 5-7 m, coll. B. Richer de Forges, September 1993, 1 ovig. ㅇ (MNHN-Na 14808).

\section{Distribution}

Type localities: Oran and Bone, Algeria. Also known from the Red Sea, Zanzibar, Sri Lanka, Ryukyu Islands, Caroline Islands, Chesterfield Islands, New Caledonia, Loyalty Islands, Wake Island, and Hawaii. Also known extensively in the Eastern Pacific, Eastern and Western Atlantic, and western Mediterranean region.

Leander tenuicornis (Say, 1818)

Palaemon tenuicornis Say 1818, p 249.

Leander tenuicornis: Kingsley 1878, p 66; Kemp 1925, p 302-304, Figure 11; Holthuis 1952b, p 155-167, Plates 41-42; Bruce 1991b, p 223, Figures 1b, 2; Chace and Bruce 1993, p 6; Bruce 1996, p 202; Bruce 2002a, p 80; Davie 2002, p 292; Li et al. 2004, p 516, Figure 3.

\section{Material examined}

Madagascar: Tuléar, coll. R. Hipeau-Jacquotte, 1960, (i) 1 đै (MNHN-Na 15926); (ii) 1 ovig. ㅇ (MNHN-Na 15927); (iii) 2 ovig. o̊ (MNHN-Na 15925). New Caledonia: (iv) MONTROUZIER, Koumac, Infernet Reef, coll. B. Richer de Forges, scuba, 13 m, 5 October 1993, 1 ovig. ㅇ (MNHN-Na 14820); (v) Ricaudy Reef, intertidal, coll. B. Richer de Forges, 12 July 1995, 1 ovig. ㅇ (MNHN-Na 15875); (vi) lagoon, Ricaudy reef flat, low tide, coll. B. Richer de Forges, 22 June 1997, 1 ^ै (MNHN-Na 15821); (vii) lagoon (Seiche Croissant), seagrass, small trawl, coll. B. Richer de Forges, 7 May 1998, 3ơ (1 ovig.) (MNHN-Na 15815). Loyalty Islands: (viii) ATELIER LIFOU, Lifou, Santal Bay: Enu, near wharf, stn $1417,20^{\circ} 46.9^{\prime} \mathrm{S}, 167^{\circ} 08.3^{\prime} \mathrm{E}, 1-4 \mathrm{~m}$, slabs with sediment cover and coral blocks, 8-24 November 2000, 1ㅇ (MNHN-Na 15431).

\section{Remarks}

Not previously recorded from Loyalty Islands. The association with anemones may have been accidental. The Madagascar material (i-iii) was collected from shelter of an actinarian Actinodendron sp. 


\section{Distribution}

Type localities: Newfoundland Bank. Also known from Red Sea and South Africa to South China Sea, Japan, Philippines, Indonesia, Australia, Caroline Islands, New Zealand, and the Atlantic Ocean from Newfoundland to Brazil, and Mediterranean. Associated with floating weed in the open sea and with attached plants in shallow water.

\section{Macrobrachium australe (Guérin-Méneville, 1838)}

Palaemon australis Guérin-Méneville 1838, p 37.

Macrobrachium australis: Chace and Bruce 1993, p 23, Figure 2; Davie 2002, p 293.

Material examined

New Caledonia: west coast (Le Cap), mangroves, coll. B. Richer de Forges, 5 December 1992, 1 ○ै (MNHN-Na 14821).

\section{Remarks}

Not previously recorded from New Caledonia.

\section{Distribution}

Type locality: Tahiti. Also known from Madagascar, Seychelles through the Indian Ocean to China (Taiwan), Philippines, Indonesia, and the Pacific islands as far as the Marshall Islands in the North Pacific and the Marquesas Islands in the South Pacific.

\section{Macrobrachium equidens (Dana, 1852)}

Palaemon equidens Dana 1852, p 26.

Macrobrachium equidens: Holthuis 1950, p 162, Figure 36; Chace and Bruce 1993, p 25, Figure 4; Davie 2002, p 295.

\section{Material examined}

New Caledonia: west coast (Le Cap), mangrove (in burrows), coll. B. Richer de Forges, 4

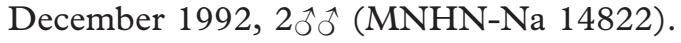

\section{Remarks}

Not previously recorded from New Caledonia. Usually found in high salinity brackish and salt water, rarely in pure fresh water.

\section{Distribution}

Type locality: Singapore. Also known from South Africa, southern India to China (Fujian), Ryukyu Islands, Philippines, Indonesia, Solomon Islands, and Nigeria (possibly introduced; Chace and Bruce 1993). 
Nematopalaemon tenuipes (Henderson, 1893)

Leander tenuipes Henderson 1893, p 440, Plate 40, Figures 14, 15.

Palaemon (Nematopalaemon) tenuipes: Holthuis 1950, p 44, Figure 7.

Nematopalaemon tenuipes: Holthuis 1980, p 108; Chace and Bruce 1993, p 39.

\section{Material examined}

Madagascar: (i) west coast, in region of Maintirano, coll. A. Crosnier, 1959, 1 ovig. ㅇ (MNHN-Na 14828); (ii) same, 1 ( $\mathrm{MNHN}-\mathrm{Na}$ 14829). Indonesia: (iii) Moluccas, Ambon, Baguala Bay, 19 October 1982, 3ọ (2 ovig.) (MNHN-Na 14827).

\section{Remarks}

Indonesian specimens have the rostral formula $2+5+? / 6^{+}$in the female and $2+3+1 / 6,2+4+1 /$ 5 in the ovigerous females. Both of the Maintirano specimens, with the rostrum broken, with seven rostral crest teeth. The ovigerous female (i) with the distal part distal to antennular peduncle lost, the female (ii) with the distal part except the apex linked with the basal part. Not previously recorded from Madagascar and Indonesia.

\section{Distribution}

Type localities: Bombay and Madras, India and Gulf of Martaban, Burma. Also known from South Africa, Madagascar, India, Thailand, China, Philippines, and Indonesia.

\section{Palaemon debilis Dana, 1852}

Palaemon debilis Dana 1852, p 26; Bruce 1991b, p 227, Figures 1d, 3f; Chace and Bruce 1993, p 40; Bruce 1996, p 202; Davie 2002, p 299; Li et al. 2004, p 521, Figure 9.

Palaemon (Palaemon) debilis: Holthuis 1950, p 66-70, Figure 13.

\section{Material examined}

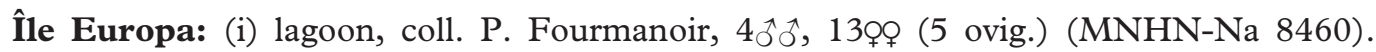
Philippines: (ii) MUSORSTOM II, shore station, Silot Bay, mangrove, 15 December 1980, 1ิ̂, 1o (MNHN-Na 15920). New Caledonia: (iii) west coast (Le Cap), mangrove, coll. B. Richer de Forges, 2 December 1992, 3 ovig. ㅇํ (MNHN-Na 14831); (iv) west coast (Le Cap), mangrove (in burrows), coll. B. Richer de Forges, 3 December 1992, 6 juveniles (MNHN-Na 14833); (v) south coast, Goro Reef flat, at low tide, coll. B. Richer de Forges, 11 January 1993, $1 \hat{\sigma}$ (with bopyrid), 1 ovig. ㅇ (MNHN-Na 14830).

\section{Parasites}

(i) Diplophryxus jordani Richardson (Isopoda: Bopyridae).

\section{Remarks}

Not previously recorded from Île Europa. 


\section{Distribution}

Type locality: Hilo, Hawaii. Common species throughout most of the Indo-West Pacific region from the Gulf of Suez to French Polynesia (Tuamotu Islands).

\section{Palaemonetes atrinubes Bray, 1976}

(Figure 1)

Palaemonetes atrinubes Bray 1976, p 76-82, Figures 23-42; Bruce 1988b, p 115-117, Figure 1; Davie 2002, p 301.

\section{Material examined}

New Caledonia: "New Caledonia”, 1903, 11 specimens (dried) (MNHN-Na 14843).

\section{Remarks}

There were no collection data with the specimens, other than "New Caledonia". The specimen label was in the handwriting of A. Milne Edwards (J. Forest, personal communication), all the material is dried, but they can still be checked.

Previously recorded from New Caledonia by Bruce (1995).

\section{Distribution}

Type locality: Lower Swan River. Also known from Australia (Western Australia, Queensland) and New Caledonia.

Urocaridella antonbruunii (Bruce, 1967)

Periclimenes antonbruunii Bruce 1967a, p 45-53, Figures 19-22.

Leandrites cyrtorhynchus Fujino and Miyake 1969, p 143-149, Figures 1-3.

Urocaridella antonbruunii: Chace and Bruce 1993, p 7; Bruce 1996, p 203, Figures 1f, 29a, 31; Davie 2002, p 301; Li et al. 2004, p 525, Figure 13.

\section{Material examined}

Madagascar: (i) Nosy Be, shallow waters, coll. A. Crosnier, 1966, 10ิ, 1 \% (MNHN-Na 15953). La Réunion: (ii) MD 32, stn CA88, $19^{\circ} 44.1^{\prime} \mathrm{S}, 54^{\circ} 08.9^{\prime} \mathrm{E}, 55-60 \mathrm{~m}, 28$ August 1982, 1 ๙ึ (MNHN-Na 14933). New Caledonia: (iii) MONTROUZIER, Touho Bay, coll. B. Richer de Forges, September 1993, 1 ovig. ㅇ (MNHN-Na 14932).

\section{Remarks}

Not previously recorded from Madagascar and La Réunion. The collection depth of the material from La Réunion is much deeper than the records from Northern Territory (1$3 \mathrm{~m}$, Bruce and Coombes 1995; $12 \mathrm{~m}$, Bruce 1983a), New Caledonia (4-12 m, Bruce 1996), Japan (5 m, Minemizu et al. 2000, p 42), Comoro Islands (20 m, Bruce 1967a), 


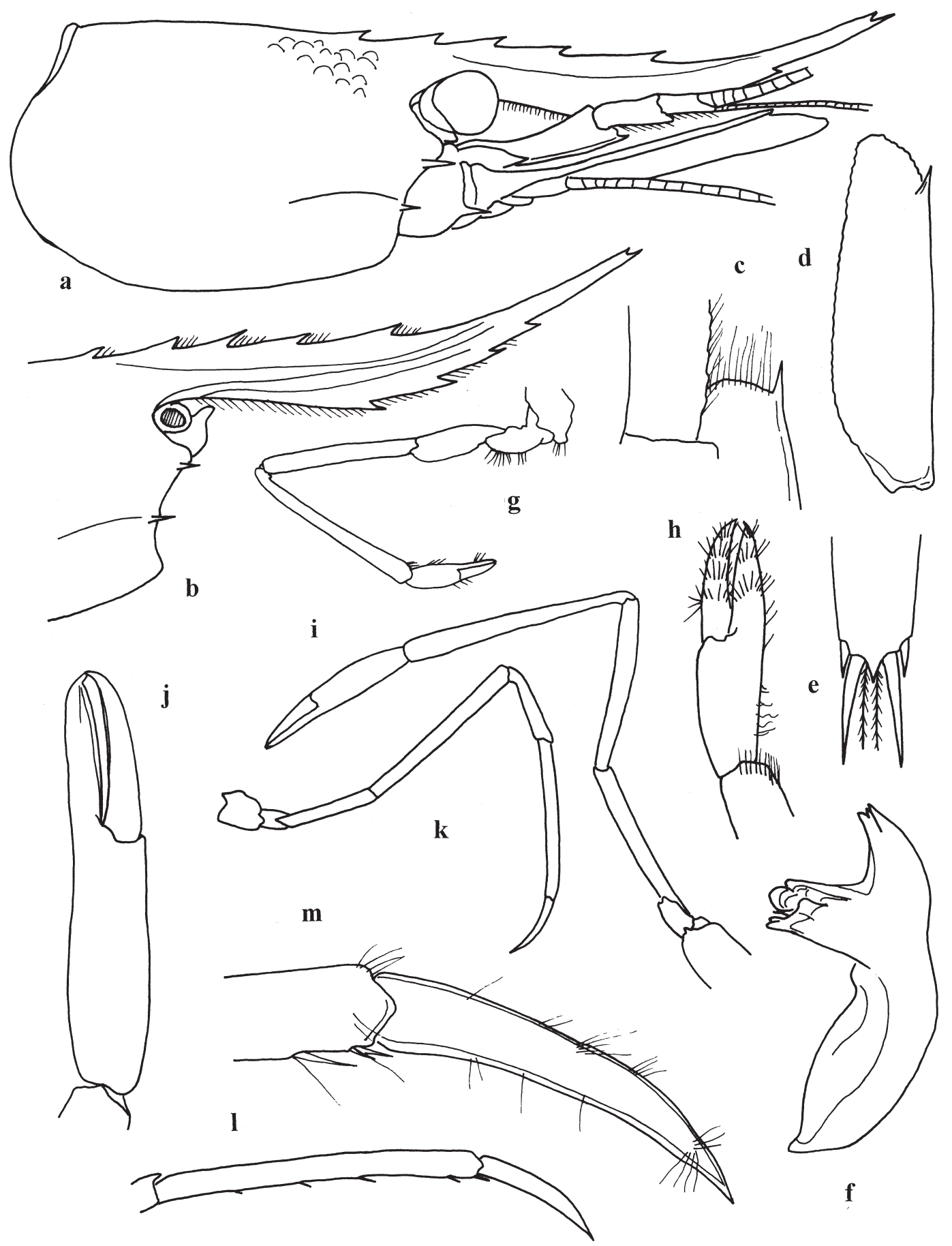

Figure 1. Palaemonetes atrinubes Bray, 1976, ovigerous female (MNHN-Na 14843). (a) Carapace and anterior appendages; (b) anterior carapace; (c) distal part of proximal peduncular segment; (d) antennal scale; (e) distal telson; (f) mandible; (g) first pereiopod; (h) same, chela; (i) second pereiopod; (j) same, chela; (k) third pereiopod; (l) same, propod and dactyl; (m) same, distal propod and dactyl. 
Bali, Indonesia (26 m, Debelius 1999). However, Li et al. (2004) recorded that the collection depth of the species from northern South China Sea is $60 \mathrm{~m}$, as well as the present record from La Réunion.

\section{Distribution}

Type locality: Dzaoudzi, Mayotte (Pamanzi Island), Comoro Islands. Also known from Kenya, La Réunion, South China Sea, Japan, Australia, New Caledonia, and Hawaii.

Urocaridella urocaridella (Holthuis, 1950)

Urocaridella gracilis Borradaile 1915, p 210.

Leander urocaridella Holthuis 1950, p 28.

Urocaridella urocaridella: Chace and Bruce 1993, p 42-44, Figure 16; Bruce 1996, p 203; Davie 2002, p 302; Li et al. 2004, p 527, Figure 14.

\section{Material examined}

Philippines: (i) MUSORSTOM 3, stn CP142, $11^{\circ} 47^{\prime} \mathrm{N}, 123^{\circ} 02^{\prime} \mathrm{E}, 26-27 \mathrm{~m}, 6$ June

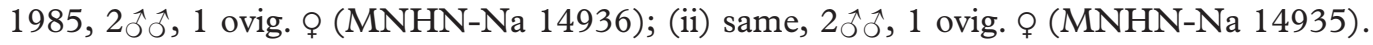
New Caledonia: (iii) BATHUS 1, stn CP680, 20 48' S, $165^{\circ} 18^{\prime} \mathrm{E}, 86-92 \mathrm{~m}, 15 \mathrm{March}$ 1993, 1ิै, 1 ovig. ㅇ (MNHN-Na 14934). Solomon Islands: (iv) SALOMON 1, stn CP $1823,9^{\circ} 50.4^{\prime} \mathrm{S}, 160^{\circ} 53.2^{\prime} \mathrm{E}, 82-83 \mathrm{~m}, 4$ October $2001,1{ }^{\dagger}$ (MNHN-Na 15434).

\section{Distribution}

Type locality: Maldives. Also known from northeastern India, Andaman Islands, Burma, Malaya, Singapore, northern South China Sea, Philippines, Indonesia, and New Caledonia.

Subfamily PONTONIINAE Kingsley, 1878

Allopontonia iaini Bruce, 1972

Allopontonia iaini Bruce 1972, p 7-11, Figures 1-5; Li 2000, p 1, Figure 1; Davie 2002, p 304.

Material examined

New Caledonia: (i) CORAIL 1, Lansdowne Bank, August 1988, 1 ovig. @ (MNHN Na14798); (ii) MONTROUZIER, Koumac, reef outer slope, 10 October 1993, 1 ovig. 우 (MNHN-Na 14799).

Host

(ii) Pseudoboletia indiana (Michelin, 1862) [Toxopneustidae, Echinoidea]. 


\section{Remarks}

The Lansdowne Bank specimen closely resembles those previously described. It is of normal size and in good condition and lacks only the tip of the rostrum. The rostrum has a dentition of at least eight dorsal and two ventral teeth and is of normal shape. Both second pereiopods are preserved and are markedly unequal, the minor second pereiopod slightly less than half the length of the very robust major pereiopod, which is about 1.75 times the carapace length of $4.75 \mathrm{~mm}$.

The Koumac specimen is rather distorted and is noticably smaller, with carapace length of about $2.76 \mathrm{~mm}$. The body appears to have been rather more strongly compressed than usual. One detached second pereiopod is preserved: all pereiopods are missing from the right side of the body.

The association with Pseudoboletia represents a new host record. The type material was collected in association with Salmaciella erythracis (H. L. Clark, 1912). Other specimens have been associated with the genera Salmacis and Asthenosoma.

Not previously recorded from New Caledonia.

\section{Distribution}

Type locality: Heron Island. Also reported from Kenya, Zanzibar, Australia (Queensland), New Caledonia, and Mexico (Baja California).

\section{Altopontonia disparostris Bruce, 1990}

Altopontonia disparostris Bruce 1990a, p 192-202, Figures 25-33, 39k; Bruce 1991a, p 390; Bruce 1996, p 204; Bruce 2005, p 2, Figure 8A; Li 2000, p 2, Figure 2.

\section{Material examined}

Vanuatu: MUSORSTOM 8, (i) stn CP1049, $16^{\circ} 39.43^{\prime} \mathrm{S}, 168^{\circ} 02.97^{\prime} \mathrm{W}, 469-525 \mathrm{~m}, 1$ October 1994, 1 ovig. o (MNHN-Na 15931); (ii) stn CP1088, 15 09.23'S, $167^{\circ} 15.13^{\prime} \mathrm{W}$, 425-455 m, 6 October 1994, 2 ovig. ㅇ (MNHN-Na 15933). New Caledonia: NORFOLK 2, (iii) Île des Pins, stn DW 2156, $22^{\circ} 54^{\prime} \mathrm{S}, 167^{\circ} 15^{\prime} \mathrm{W}, 468-500 \mathrm{~m}, 5$ November 2003, 1 ovig. \& (MNHN-Na 15932). Fiji: BORDAU 1, (iv) stn DW 1492, $18^{\circ} 43^{\prime} \mathrm{S}, 178^{\circ} 23^{\prime} \mathrm{W}, 430-450 \mathrm{~m}, 11$ March 1999, 2oᄋ (1 ovig.) (MNHN-Na 15436); (v) stn CP $1505,18^{\circ} 12^{\prime} \mathrm{S}, 178^{\circ} 37^{\prime} \mathrm{W}, 420-450 \mathrm{~m}, 13$ March 1999, 10 ovig. ọ (MNHN-Na 15435).

\section{Remarks}

Not previously recorded from Vanuatu and Fiji. Bruce (2005) illustrated the coloration.

\section{Distribution}

Type locality: off New Caledonia. Also known from Tasman Sea, Vanuatu and Fiji; 322$525 \mathrm{~m}$. 
Amphipontonia kanak Bruce, 1991

Amphipontonia kanak Bruce 1991a, p 382-390, Figures 58-63.

\section{Material examined}

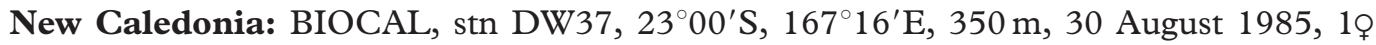
(MNHN-Na 15633).

\section{Remarks}

The present record slightly extends this species bathymetric range, from 300 to $350 \mathrm{~m}$.

\section{Distribution}

Type locality: New Caledonia and Loyalty Islands.

Anchistus custos (Forskål, 1775)

Cancer custos Forskål 1775, p xxi, 94.

Harpilius inermis Miers 1884, p 291, Plate 32, Figure B.

Anchistus inermis: Borradaile 1898, p 387.

Anchistus custos: Holthuis 1952a, p 105-109, Figures 43, 44; Chace and Bruce 1993, p 72;

Bruce 1996, p 205; Li 2000, p 7, Figure 8; Davie 2002, p 305; Li and Liu 2002, p 371, Figure 1; Li et al. 2004, p 528.

\section{Material examined}

Madagascar: Tuléar, coll. R. Hipeau-Jacquotte, (i) 19 March 1968, 84 specimens (spms) (36 ovig. ơ) (MNHN-Na 15958); (ii) 50 spms (MNHN-Na 15970). New Caledonia: (iii) MONTROUZIER, Koumac, scuba, coll. B. Richer de Forges, 6 September 1993,

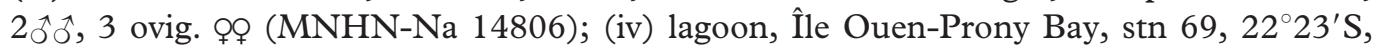
$166^{\circ} 32^{\prime} \mathrm{E}, 13 \mathrm{~m}$, coll. B. Richer de Forges, no date record, $1 \widehat{o}^{\uparrow}$ (MNHN-Na 11433[e]); (v) Nouméa, associated with "grand Pinna", coll. J. Risbec (Th. Monod Collection number

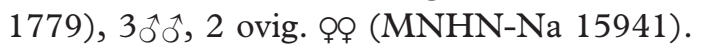

\section{Host}

(i) (ii) Atrina sp. [Pinnidae, Mollusca].

Remarks

Previously recorded from New Caledonia at Saint Vincent Bay (Bruce 1996).

\section{Distribution}

Type locality: Al Luhayyah, Yemen. Known from Red Sea and eastern Africa to Philippines, southward to Australia (South Australia), and eastward to the Caroline Islands and Fiji. 
Anchistus miersi (De Man, 1888)

Harpilius Miersi De Man 1888, p 274, Plate 17, Figures 6-10.

Anchistus miersi: Borradaile 1898, p 387; Bruce 1978a, p 279; Chace and Bruce 1993, p 72;

Li 2000, p 11, Figure 11; Davie 2002, p 305; Li 2004a, p 67.

\section{Material examined}

Madagascar: northwest coast, Nosy Be (Andilah), intertidal, in Tridacna spp., coll. A

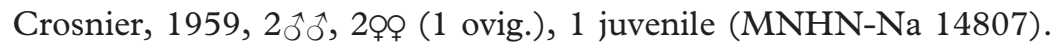

\section{Remarks}

In all specimens, the lateral posterior telson spines were situated subterminally on the dorsum of the telson, and the female specimen with two pairs of median posterior telson spines. Previously recorded from Madagascar (Nosy Be) by Bruce (1978a).

\section{Distribution}

Type locality: Mergui Archipelago. Known from Red Sea and eastern Africa to the Philippines, Indonesia, Australia (Queensland), and eastward to French Polynesia (Tuamotu Islands and Gambier Islands).

\section{Anchistus pectinis Kemp, 1922}

Anchistus pectinis Kemp 1925, p 327; Bruce 1991a, p 378, Figures 56-57, 71b-f; Bruce 1991b, p 261, Figure 24; Bruce 1996, p 205, Figures 2-3; Li 2000, p 12, Figure 12.

\section{Material examined}

New Caledonia: BATHUS 4, $19^{\circ} 49.00^{\prime} \mathrm{S}, 163^{\circ} 48.40^{\prime} \mathrm{E}, 37 \mathrm{~m}, 9$ August 1994, $1 \mathrm{o}^{\hat{O}}, 1$ o, 4 ovig. 우 (MNHN-Na 15894).

\section{Remarks}

Previously recorded from New Caledonia by Bruce (1991b).

\section{Distribution}

Type locality: Nicobar Islands. Also known from Zanzibar, Nicobar Islands, Japan, northeast Australia, and New Caledonia, 10-110 m. Associated with pectinid mollusks Amusium, Pecten, and Semipallium. 
Climeniperaeus truncoideus (Chace and Bruce, 1993)

Periclimenaeus truncatus: Holthuis 1952a, p 117, Figures 48-50; Bruce 1981a, p 211, Figures 16, 17d, 18c, f (non Coralliocaris truncata Rathbun 1906).

Periclimenaeus truncoideus Chace and Bruce 1993, p 93-94.

Climeniperaeus truncoideus: Bruce 1996, p 210, Figures 4, 5; Li 2000, p 22, Figure 23.

\section{Material examined}

Providence Island: (1) ?stn D11, 91.5 m, 4 October ?2003, 2 spms (dried) (MNHN-Na 15945). Philippines: (ii) MUSORSTOM 3, stn DR117, $12^{\circ} 31^{\prime} \mathrm{N}, 120^{\circ} 39^{\prime} \mathrm{E}, 92-95 \mathrm{~m}, 3$ June 1985, 1o (MNHN-Na 11333[f]).

\section{Remarks}

Previously recorded from Philippines by Bruce (1981a, 1996). Not previously recorded from Providence Island.

\section{Distribution}

Type locality: Indonesia. Also known from Zanzibar and Philippines.

Conchodytes biunguiculatus (Paulson, 1875)

Pontonia biunguiculata Paulson 1875, p 111, Plate 15, Figure 1.

Conchodytes biunguiculatus: Kemp 1922, p 279, 280-282, Figure 102; Holthuis 1952a, p 17, 199-200; Jacquotte 1963, p 61; Fransen 1994, p 89, Figures 3-7, 12-15, 23, 27, 30, 35; Li 2000, p 24, Figure 24; Li 2001, p 76; Li and Liu 2002, p 372, Figure 2a-f; Bruce 2003, p 212.

Conchodytes kempi Bruce 1989a, p 183.

\section{Material examined}

Madagascar: Tuléar, coll. R. Hipeau-Jacquotte, (i) 45 spms (MNHN-Na 15968); (ii) 19

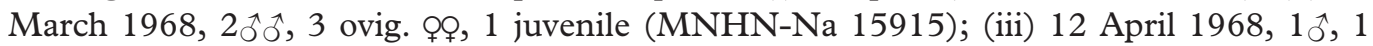
ovig. ᄋ (MNHN-Na 15923).

\section{Hosts}

(i) (ii) Atrina sp.; (iii) Atrina vexillum (Born, 1778) [Pinnidae, Mollusca].

\section{Remarks}

First reported from Madagascar at Toliara (Tuléar) by Jacquotte (1963) and subsequently studied in detail.

\section{Distribution}

Type locality: Red Sea. Also known from Western Indian Ocean to South China Sea, Philippines, Indonesia, and Marshall Islands. 
Conchodytes maculatus Bruce, 1989

Conchodytes maculatus Bruce 1989b, p 182, Figures 1-6; Li 2000, p 25, Figure 25.

Material examined

New Caledonia: MONTROUZIER, Touho Sector, Sand Islet, Touho Pass, stn 1272, $20^{\circ} 49.5^{\prime} \mathrm{S}, 165^{\circ} 19.6^{\prime} \mathrm{E}, 10 \mathrm{~m}$, hard bottom with mud, September 1993, 1 ovig. o (MNHN$\mathrm{Na} 15885)$.

Remarks

Not previously recorded from New Caledonia. Known from intertidal zone to $40 \mathrm{~m}$ depth, in association with pearl oysters.

\section{Distribution}

Type locality: Australian Northwest Shelf. Also known from Philippines and New Caledonia.

\section{Conchodytes meleagrinae Peters, 1852}

Conchodytes meleagrinae Peters 1852, p 594; Bruce 1978a, p 279; Bruce 1991b, p 262, Figure 25a-d; Chace and Bruce 1993, p 74; Li 2000, p 25, Figure 26; Davie 2002, p 307; Li 2004a, p 67.

\section{Material examined}

Île Europa: (i) $1 \hat{\jmath}(\mathrm{MNHN}-\mathrm{Na}$ 14810). Malaya (or Vietnam): (ii) associated with Meleagrina sp., $1 \hat{\jmath}$ (MNHN-Na 15939). New Caledonia: (iii) reef inside Abore, $4 \mathrm{~m}$, with

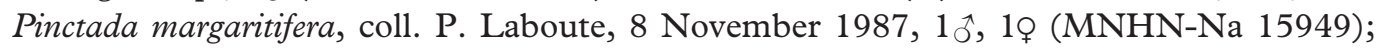
(iv) MONTROUZIER, Grand Récif, Mangalia, in pearl oysters, coll. B. Richer de Forges, 15 September 1993, 1 ô, 2 ovig. ọ (MNHN-Na 14809). Loyalty Islands: (v) ATELIER LIFOU, Lifou, Santal Bay: west or southwest of Easo Point, stn 1429, 20 47.5'S, $167^{\circ} 07.1^{\prime} \mathrm{E}, 8-18 \mathrm{~m}$, sedimentary channels, 3/5/23-24 November 2000, 1 ovig. 우 (MNHN-Na 15437).

\section{Remarks}

Previously recorded from New Caledonia on Touaorou Reef, Yaté (Bruce 1991b). Previously recorded from Madagascar: Île Europa by Bruce (1978a). Not previously recorded from Loyalty Islands.

\section{Distribution}

Type locality: Mozambique (Ibo, Cabo Delgado), southeastern coast of Africa. Also known from Red Sea eastward to Hawaii. 
Coralliocaris sp. Mitsuhashi and Takeda, 2006

\section{Material examined}

Loyalty Islands: ATELIER LIFOU, Lifou. Chateaubriand Bay: (i) Gaatcha Bay, stn $1463,20^{\circ} 55.05^{\prime} \mathrm{S}, 167^{\circ} 03.35^{\prime} \mathrm{E}, 30 \mathrm{~m}$, dredge, sand and coral debris, 10 November 2000 , 1 ( $(\mathrm{MNHN}-\mathrm{Na} 15442)$; (ii) Wé Beach, stn 1474, 20 $54.8^{\prime} \mathrm{S}, 167^{\circ} 16.1^{\prime} \mathrm{E}, 30 \mathrm{~m}$, fine sand and heads of Porites, 11 November 2000, 1 ovig. \& (MNHN-Na 15439). Santal Bay: (iii) northeast Chateaubriand Bay, Cila, stn $1456,20^{\circ} 49.3^{\prime} \mathrm{S}, 167^{\circ} 10.4^{\prime} \mathrm{E}$, slope, 25-30 m, 26 November 2000, 1 ovig. \& (MNHN-Na 15444).

\section{Remarks}

Only the ovigerous female of (ii) has the second pereiopods present. Rostrum reaches distal margin of first antennular peduncle segment, armed with two or three dorsal and one ventral tooth, the ventral tooth minute and subapical. Antennal spine on carapace relatively stout and long, reaches almost to the distal margin of basicerite. The depth of $30 \mathrm{~m}$ is a particularly deep record for this genus.

Dr. M. Mitsuhashi is reviewing the Coralliocaris nudirostris (Heller, 1861) and its closely related species. After checking the present specimens, she considers that it should be a species close to $C$. nudirostris (personal communication).

\section{Distribution}

Type locality: Japan (Ryukyu Islands), Papua New Guinea, Loyalty Islands, Australia (Queensland). The other localities outside the type localities should be re-examined (see Remarks).

Coralliocaris macrophthalma (H. Milne-Edwards, 1837)

Pontonia macrophthalma H. Milne Edwards 1837, p 359.

Coralliocaris macrophthalma Borradaile 1917, p 383; Holthuis 1952a, p 17; Chace and Bruce 1993, p 47, 77; Bruce 1998, p 30.

Coralliocaris graminea: Bruce 1977a, p 204, Figure 1; Li 2000, p 33.

\section{Material examined}

New Caledonia: lagoon, Amédée Reef flat, from seagrass, coll. C. Vadon, 17 September 1978, 1 ovig. \& (MNHN-Na 15862).

Remarks

Not previously recorded from New Caledonia.

\section{Distribution}

Type locality: seas of Asia. Also known from Israel, Red Sea, Seychelles, Saya de Malha Australia (Great Barrier Reef (?)), and New Caledonia. 
Oedipus superbus Dana 1852, p 25.

Coralliocaris superba (Dana, 1852)

Oedipus dentirostris: Paulson 1875, p 112, Plate 14, Figure 7.

Coralliocaris superba: Stimpson 1860, p 38; Hipeau-Jacquotte 1973, p 104; Bruce 1991b, p 264, Figure 26; Chace and Bruce 1993, p 77; Li 2000, p 35, Figure 35; Davie 2002, p 309; Li and Liu 2002, p 375, Figure 4a-d.

\section{Material examined}

Madagascar: (i) west coast, Toliara (Tuléar), intertidal, coll. A. Crosnier, October 1958, 1 ovig. ㅇ (MNHN-Na 14812). New Caledonia: (ii) MONTROUZIER, Touho (Tié), coll. B. Richer de Forges, scuba, 5-7 m, 1 ovig. o (MNHN-Na 14811).

\section{Remarks}

The two specimens, which both lack second pereiopods, have rostral dentitions of $5 / 2$ and $6 / 5$, respectively. The ambulatory dactyls have a particularly acute tip to the hoof-shaped ventral process. Previously recorded from New Caledonia in Nouméa and Île Ouen, Baie du Prony (Monod 1976; Bruce 1991b). Previously recorded from Madagascar (Tuléar) by Hipeau-Jacquotte (1973).

\section{Distribution}

Type locality: Tongatabu Island, Tonga. Also known from Red Sea, Mozambique and Madagascar to Indonesia, Australia (Western Australia, Queensland, New South Wales, Tasman Sea), eastward to French Polynesia (Society Islands).

\section{Coralliocaris viridis Bruce, 1974}

Coralliocaris viridis Bruce 1974a, p 222-224, Figure 1; Chace and Bruce 1993, p 78; Li 2000, p 38, Figure 38; Davie 2002, p 309.

\section{Material examined}

Madagascar: (i) northwest coast, Nosy Be (Ambatoloaka), coll. A. Crosnier, September 1958, 1 ovig. \& (MNHN-Na 14813); (ii) Îles Glorieuses, intertidal, coll. A. Crosnier, September 1958, 1َ̧, 1 ovig. @ (MNHN-Na 14814).

\section{Remarks}

The Îles Glorieuses specimens lack second pereiopods but have very slender rostra with a dentition of 4/1 and 5/1, respectively. The Nosy Be specimen has both second pereiopods and a rostral dentition of $5 / 2$, all teeth distally situated. Not previously recorded from Madagascar. 


\section{Distribution}

Type locality: Mombasa Island, Kenya. Also known from Mozambique, Seychelles, Maldive Islands, Sri Lanka, Vietnam, Ryukyu Islands, Indonesia, Papua-New Guinea, and Australia (Northern Territory and Queensland).

Dasycaris ceratops Holthuis, 1952

Dasycaris ceratops Holthuis 1952a, p 176, Figures 87, 88; Bruce 1977b, p 173, Figure 5; Chace and Bruce 1993, p 80; Li 2000, p 43, Figure 44.

Material examined

Madagascar: Nosy Be, shallow water, coll. A. Crosnier, 1966, 1^^, 1 ovig. $९$ (MNHN-Na 15964).

Remarks

Not previously recorded from Madagascar.

\section{Distribution}

Type localities: Boeo Bank, Indonesia. Also known from Zanzibar, Madagascar, China, Indonesia, and Australia (Queensland).

Dasycaris symbiotes Kemp, 1922

Dasycaris symbiotes Kemp 1922, p 240, Figures 76, 77, Plate 9; Monod 1976, p 147, Figures 54-60; Li 1997, p 230, Figure 6; Li 2000, p 44, Figure 45.

Material examined

New Caledonia: Dumbéa Bay, $22^{\circ} 13.38^{\prime} \mathrm{S}, 166^{\circ} 22.17^{\prime} \mathrm{E}$, scuba, $20 \mathrm{~m}$, coll. Bargibant, 30 November 1995, 1ð (MNHN-Na 15893).

\section{Remarks}

Previously recorded from New Caledonia by Monod (1976).

\section{Distribution}

Type localities: India and Mergui Archipelago, 27-31 m, $64 \mathrm{~m}$. Also known from South China Sea (Xisha Islands) and New Caledonia. Associated with sea pen, Pteroeides sp. 
Dasycaris zanzibarica Bruce, 1973

Dasycaris zanzibarica Bruce 1973b, p 247-257, Figures 1-6; Bruce 1991b, p 265,

Figure 27; Bruce 1996, p 214; Li 2000, p 45, Figure 46; Davie 2002, p 310.

\section{Material examined}

Madagascar: west coast, Pracel Bank, $25 \mathrm{~m}$, beam trawl, on brown mud, coll. A. Crosnier, June 1959, 1 ovig. o (MNHN-Na 14815).

\section{Remarks}

Not previously recorded from Madagascar. Also reported from $39 \mathrm{~m}$ at Atoll de Surprise,

New Caledonia, and otherwise recorded only from shallow water.

\section{Distribution}

Type locality: Changu Island, Zanzibar. Also known from Japan, Taiwan, Philippines, Papua New Guinea, Australia (Western Australia, Great Barrier Reef), and New Caledonia.

\section{Exoclimenella denticulata (Nobili, 1906)}

Periclimenes Petitthouarsi var. denticulata Nobili 1906a, p 257; Nobili 1907, p 358-359.

Periclimenes (Falciger) denticulatus: Borradaile 1917, p 368, 372.

Periclimenes denticulatus: Bruce 1992, p 59, Figures 12-14.

Exoclimenella denticulata: Duris and Bruce 1995, p 637, Figures 9-11; Li 2000, p 49, Figure 52.

\section{Material examined}

Loyalty Islands: ATELIER LIFOU, Lifou, Xepenehe Point, in coral mats, scuba, 1213 m, 11 November 2000, 1 ๙ै (MNHN-Na 15446).

\section{Remarks}

The specimen has the dorsal surface of fixed finger of major second pereiopod with a very deep longitudinal groove. Not previously recorded from Loyalty Islands.

\section{Distribution}

Type locality: Gatavake, Mangareva Atoll, Gambier Islands. Also known from South China Sea, Australia (Great Barrier Reef), Marshall Islands, and French Polynesia (Tuamotu Islands). 
Exoclimenella cf. denticulata (Nobili, 1906)

\section{Material examined}

Loyalty Islands: ATELIER LIFOU, Lifou, Santal Bay: in front of Peng, stn 1464, $20^{\circ} 54.5^{\prime} \mathrm{S}, 167^{\circ} 05.9^{\prime} \mathrm{E}, 30-50 \mathrm{~m}$, dredges, blocks of calcareous algae, 14 November 2000 , 1 ovig. \& (MNHN-Na 15447).

\section{Remarks}

Carpus of second pereiopods is distinctly longer than that of the original description.

Exoclimenella maldivensis Duris and Bruce, 1995

Exoclimenella maldivensis Duris and Bruce 1995, p 622, Figures 1-5; De Grave 2000, p 123.

\section{Material examined}

Loyalty Islands: ATELIER LIFOU, Lifou, Santal Bay, (i) west or southwest of Easo Point, stn $1429,20^{\circ} 47.5^{\prime} \mathrm{S}, 167^{\circ} 07.1^{\prime} \mathrm{E}, 8-18 \mathrm{~m}$, sedimentary channels, 3/5/23-24 November 2000, 1ิे, 1o, 1 juvenile (MNHN-Na 15449); (ii) east of bay, in front of

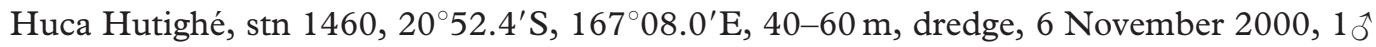
(MNHN-Na 15454); (iii) Gaatcha Bay, stn 1463, 20 55.05'S, $167^{\circ} 03.35^{\prime} \mathrm{E}, 20-30 \mathrm{~m}$, dredge, sand and coral debris, 10 November 2000, $1 \hat{0}$ (MNHN-Na 15455); (iv) east of Santal Bay: Mepinyo, stn $1446,20^{\circ} 50.8^{\prime} \mathrm{S}, 167^{\circ} 09.7^{\prime} \mathrm{E}, 36-40 \mathrm{~m}$, bottom of slope, 16 November 2000, 1 ovig. @ (MNHN-Na 15452); (v) north of Cap Aimé Martin (=Acadro),

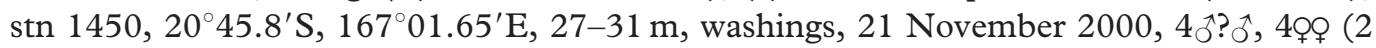
ovig.) (MNHN-Na 15457); (vi) between Cap Mande and Cap Lefèvre (=Nem), stn 1452, $20^{\circ} 54.6^{\prime} \mathrm{S}, 167^{\circ} 02.1^{\prime} \mathrm{E}, 2-25 \mathrm{~m}$, scuba, 22 November 2000, 1 juvenile (MNHN-Na 15456); (vii) between Cap Wekutr and Cap Wajez, stn $1455,20^{\circ} 56.8^{\prime} \mathrm{S}, 167^{\circ} 02.7^{\prime} \mathrm{E}$, slope, 15-20 m, 25 November 2000, 1 ภ, 1 ovig. @ (MNHN-Na 15450); (viii) northeast Santal Bay, in region of Cila, stn $1456,20^{\circ} 49.3^{\prime} \mathrm{S}, 167^{\circ} 10.4^{\prime} \mathrm{E}$, slope, 25-30 $\mathrm{m}, 26$ November 2000, $2 \hat{\jmath} \widehat{\jmath}, 1$ ovig. @ (MNHN-Na 15451); (ix) in front of Ngoni, stn 1457, $20^{\circ} 46.8^{\prime} \mathrm{S}, 167^{\circ} 02.75^{\prime} \mathrm{E}, 5-10 \mathrm{~m}$, dark overhang and boulders, 27 November 2000,1 今ิ, 1 ovig. ㅇ (MNHN-Na 15453).

\section{Remarks}

Not previously recorded from Loyalty Islands. The specimen (i) with $2+7 / 5$ rostral dentition, the subapical dorsal tooth tiny; the female and juvenile of (vii), male of (iii) lack both second pereiopods, the male also lacks the carapace and the appendages anterior to the second pereiopods, but both the pereiopods are present; specimens of (iii) and (vi) lack both second pereiopods and (vii) the rostrum is broken.

\section{Distribution}

Type locality: Maldives, Timor Sea. Also known from Thailand, Japan, and Loyalty Islands. 
Hamodactylus boschmai Holthuis, 1952

Hamodactylus boschmai Holthuis 1952a, p 209, Figures 102-104; Bruce 1970a, p 538,

Figure 1; Bruce 1982, p 272, Figures 25, 26; Bruce and Coombes 1995, p 108; Li 2000, p 58, Figure 61 .

Material examined

New Caledonia: lagoon, with crinoids, 30 August 1993, 1 spm (MNHN-Na 15840).

\section{Remarks}

The only specimen was damaged. Rostrum, telson, all pleopods and most of ambulatory pereiopods lost, but both second, left first and left fifth pereiopods are present. The species was first reported from New Caledonia near Nouméa, by Bruce (1970a). The association with crinoids is probably accidental.

\section{Distribution}

Type locality: Ternate, Aru Islands, Indonesia, 2-13 m. Also known from Zanzibar, Kenya, Madagascar, Indonesia, and New Caledonia.

Hamodactylus noumeae Bruce, 1970

Hamodactylus noumeae Bruce 1970a, p 539-541, Figure 2; Chace and Bruce 1993, p 80; Li 2000, p 59, Figure 62; Davie 2002, p 312.

Material examined

New Caledonia: MONTROUZIER, Koumac Pass, $35 \mathrm{~m}$, gorgonian washings, 28

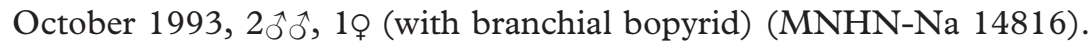

\section{Remarks}

The female specimen has five dorsal rostral teeth and both males have four. This species was first described from Nouméa, New Caledonia (Bruce 1970a), but there have been no subsequent reports from these islands.

\section{Distribution}

Type locality: Nouméa, New Caledonia. Also known from Zanzibar, Tanzania, Kenya, Seychelles, Japan, and Australia (Western Australia, Northern Territory, Queensland). 
Hamopontonia corallicola Bruce, 1970

Hamopontonia corallicola Bruce 1970b, p 41, Figures 1-4; Bruce 1983b, p 896, Figure 10G; Li 2000, p 59, Figure 63.

\section{Material examined}

Philippines: MUSORSTOM II, shore station, stn 11, opposite Mactan Marine Station, scuba, 5-18 m, with fungiid coral, 9 December 1980, 1 ๙ึ (MNHN-Na 15960).

Remarks

Not previously reported from the Philippines.

\section{Distribution}

Type locality: Hong Kong. Also known from Japan, Philippines, Indonesia, and Australia (Great Barrier Reef).

Harpiliopsis beaupresii (Audouin, 1825)

Palaemon Beaupresii Audouin 1825, p 91.

Harpilius Beaupresii: Heller 1861, p 27.

Harpiliopsis beaupresi: Borradaile 1917, p 324, 379, Plate 55, Figure 21; Chace and Bruce 1993, p 82; Li 2000, p 61, Figure 65; Davie 2002, p 312; Li and Liu 2003, p 154, Figure 1.

\section{Material examined}

Madagascar: (i) Ambataloaka, Nosy Be, coll. A. Crosnier, September 1958, 1 ovig. $q$ (MNHM-Na 14817). La Réunion: (ii) no date, coll. S. Ribes, 1 juvenile (MNHN-Na 14818). Loyalty Islands: ATELIER LIFOU, (iii) Lifou, Santal Bay: in front of Huca Hutighé Islet, stn $1434,20^{\circ} 52.5^{\prime} \mathrm{S}, 167^{\circ} 08.1^{\prime} \mathrm{E}, 5-20 \mathrm{~m}$, hard bottom, 6 November 2000 , 2ิึิ (MNHN-Na 15445).

Host

Pocillopora damicomis (L., 1758) [Pocilloporidae, Scleractinia].

\section{Remarks}

Both specimens had a rostral dentition of 5/2. Previously reported from both La Réunion (Bruce 1983c) and Madagascar (Hipeau-Jacquotte 1973), but not Loyalty Islands.

\section{Distribution}

Type locality: Egyptian Red Sea. Also known from Gulf of Aqaba, Sudan, Ethiopia (Eritrea), Yemen, Kenya, Zanzibar, Mozambique, Madagascar, Seychelles, La Réunion, Mauritius, Maldives, Chagos Islands, Sri Lanka, Andaman Islands, Thailand, Singapore, Vietnam, South China Sea, Japan, Philippines, Indonesia, Australia (Western Australia, Northern Territory, Queensland), Coral Sea, Loyalty Islands, Fiji, Marshall Islands, USA (French Frigate Shoal, Johnson Atoll, Hawaii), and Easter Island. 
Harpiliopsis depressa (Stimpson, 1860)

Harpilius depressus Stimpson 1860, p 38; Kemp 1922, p 231, Figures 69, 70.

Harpiliopsis depressus: Borradaile 1917, p 380; Holthuis 1951, p 70, Plates 21, 22, Figures af; Holthuis 1952a, p 182, Figure 90; Bruce 1970d, p 306; Bruce 1991b, p 263; Fransen 1994, p 107, Figures 59, 61; Li 1997, p 233; Li 1998, p 222, Figures 8-11; De Grave 2000, p 124.

Periclimenes pusillus Rathbun 1906, p 921, Figure 71, Plate 24, Figure 7.

\section{Material examined}

New Caledonia: Boulari Pass, stn 505, scuba, on Pocillopora sp., coll. J.-L. Menou, 12 April 1994, 1ðै (MNHN-Na 15854).

\section{Remarks}

Previously recorded from New Caledonia by Bruce (1991b).

\section{Distribution}

Type locality: Hawaii. Common and widespread throughout most of the Indo-Pacific region: Egypt, Israel, Saudi Arabia, Sudan, Yemen, Kenya, Zanzibar, Mozambique, Comoro Islands, Madagascar, Seychelles, La Réunion, Maldives, Chagos Islands, Sri Lanka, Andaman Islands, Nicolar Islands, Indonesia, Papua New Guinea, South China Sea, Japan, Philippines, Australia (Western Australia, Queensland), Mariana Islands, New Caledonia, Loyalty Islands, Marshall Islands, Ellice Islands (Rotuma Island), Fiji, Samoan Islands, Kiribati, Line Islands (Palmyra Island), Hawaii, Johnson Atoll; also Galapagos Islands, Mexico, Costa Rica, Panama, Colombia, and Ecuador. Associated with Pocillopora, Seriatopora, Stylophora, rarely Acropora and Porites.

\section{Harpiliopsis spinigera (Ortmann, 1890)}

(Figure 2)

Anchistia spinigera Ortmann 1890, p 511, Plate 36, Figure 23.

Harpilius depressus var. gracilis Kemp 1922, p 234, Figure 71.

Harpiliopsis depressus var. spinigerus: Holthuis 1952a, p 184-185.

Harpiliopsis spinigera: Chace and Bruce 1993, p 82; De Grave 2000, p 124; Li 2000, p 64, Figure 67; Davie 2002, p 313; Marin et al. 2004, p 201, Figure 2.

\section{Material examined}

New Caledonia: Croissant Reef, dive station 533, scuba, $20 \mathrm{~m}$, coll. Bargibant and Menou, 18 April 1994, 1̊ (MNHN-Na 15838).

\section{Remarks}

Not previously recorded with certainty from New Caledonia. Associated with Pocillopora and Stylophora. 


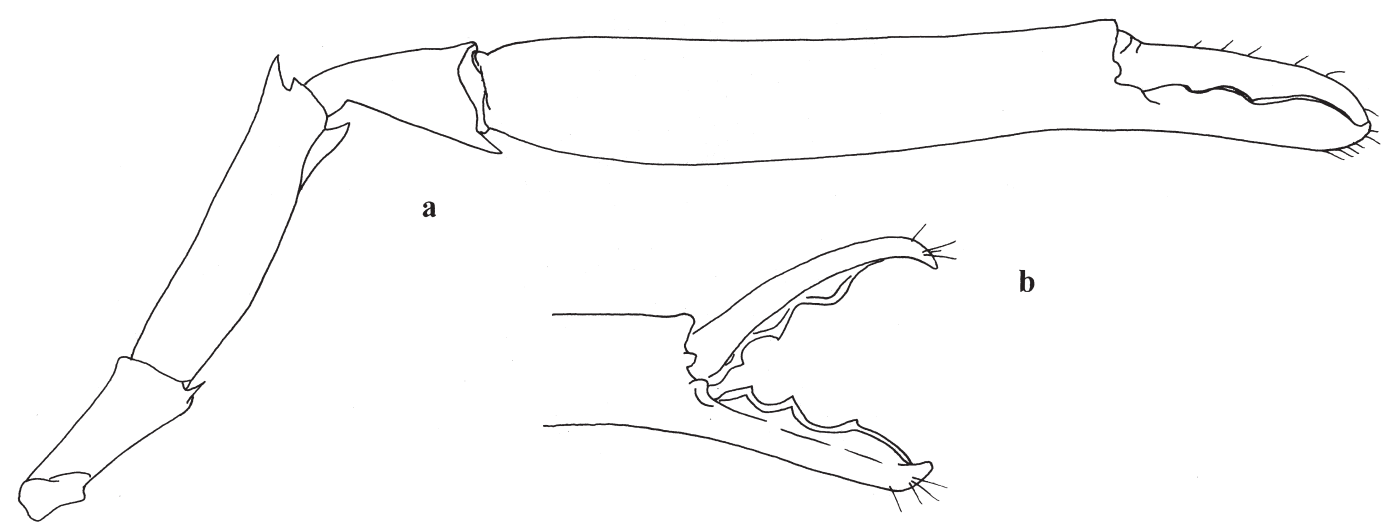

Figure 2. Harpiliopsis spinigera (Ortmann, 1880), male (MNHN-Na 15838). (a) Second pereiopod; (b) same, fingers.

\section{Distribution}

Type locality: Samoa. Also known from Kenya, Zanzibar, Comoro Islands, Seychelles, La Réunion, Maldives, Andaman Islands, Vietnam, Philippines, Indonesia, Australia (Queensland), New Caledonia, Fiji, Marshall Islands, and, in the East Pacific region, Panama and Colombia.

Harpilius lutescens Dana, 1852

Harpilius lutescens Dana 1852, p 25; Bruce 2004, p 6.

Periclimenes (Ancylocaris) amamiensis Kubo 1940b, p 44-46, Figures 11, 12.

Periclimenes (Harpilius) lutescens: Holthuis 1952a, p 88-91, Figure 35.

Periclimenes lutescens: Chace and Bruce 1993, p 117; Li 2000, p 209, Figure 271; Davie 2002, p 329.

\section{Material examined}

Loyalty Islands: MUSORSTOM 6, stn DW431, $20^{\circ} 22.25^{\prime} \mathrm{N}, 166^{\circ} 10.00^{\prime} \mathrm{E}, 21 \mathrm{~m}, 18$ February 1989, 1へิ (MNHN-Na 14916).

\section{Remarks}

This common and widely distributed coral associate, one of the first pontoniine shrimps to be described, has not been previously reported from Loyalty Islands. The specimen has a rostral dentition of 1 (?)+6/2, and lacks both second pereiopods. The second maxilliped has the characteristic diagnostic distal segments and the third maxilliped has a well-developed arthrobranch. The ambulatory dactyls are also typical of this species. The present depth record may represent the maximum depth from which this species has so far been recorded.

\section{Distribution}

Type locality: Tongatapu Island, Tonga. Also known from the Red Sea, Egypt, Israel, Saudi Arabia, Sudan, Ethiopia (Eritrea), Kenya, Zanzibar, Tanzania, Comoro Islands, 
Madagascar, Seychelles, Maldives, Singapore, Vietnam, Japan, Indonesia, Australia (Northern Territory, Queensland), Coral Sea, Solomon Islands, Loyalty Islands, Tonga, and Samoan Islands. Also, French Polynesia (Society Islands) and Marquesas Islands.

Ischnopontonia lophos (Barnard, 1962)

Philarius lophos Barnard 1962, p 242, Figure 2.

Ischnopontonia lophos: Bruce 1966a, p 584, Figures 1-5; Bruce 1976a, p 120; Bruce and Coombes 1995, p 109; De Grave 2000, p 125, Figure 2; Li 2000, p 67, Figure 68; Li and Liu 2003, p 156, Figure 2.

\section{Material examined}

Madagascar: Tuléar, Grand Récif, coll. R. Hipeau-Jacquotte, 1968, 1 1ึ, 3ọ (2 ovig.) (MNHN-Na 15832).

Host

Galaxea sp. [Oculinidae, Scleractinia].

Remarks

First recorded from Madagascar by Bruce (1976a).

\section{Distribution}

Type locality: Inhaca Island, Mozambique. Also known from Kenya, Zanzibar, Tanzania, Comoro Islands, Madagascar, Seychelles, Malaya, Singapore, South China Sea, Ryukyu Islands, Australia (Northern Territory, Queensland), Caroline Islands, and Fiji.

Jocaste japonica (Ortmann, 1890)

Coralliocaris superba var. japonica Ortmann 1890, p 509.

Focaste japonica: Holthuis 1952a, p 193-195, Figure 94 (partim); Patton 1966, p 279-280, Figure 3b; Bruce 1969a, p 300, Figure 1; Bruce 1979a, p 239; Li 1996, p 225, Figure 4; Li 1997, p 233; Li 1998, p 222; Li 2000, p 69-70, Figure 70; Li 2001, p 79; Li and Liu 2003, p 157, Figure 3; Bruce 2003, p 219; Li 2004a, p 68.

\section{Material examined}

Loyalty Islands: ATELIER LIFOU, Lifou, Santal Bay: near Huca Hutighé Islet, stn

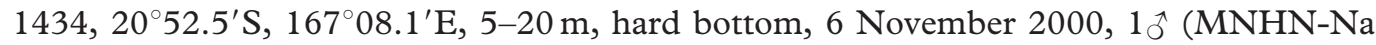
15458).

Remarks

Not previously recorded from Loyalty Islands. Associated with Acropora.

\section{Distribution}

Type locality: Kagoshima, Japan. Also known from Kenya, Zanzibar, Tanzania, Mozambique, Comoro Islands, Madagascar, Seychelles, Mauritius, La Réunion, 
Maldives, Chagos Islands, Vietnam, South China Sea, Japan, Philippines, Indonesia, Papua New Guinea, Australia (Western Australia, Queensland), Mariana Islands, Caroline Islands, New Caledonia, Loyalty Islands, Marshall Islands, Cook Islands, and Fiji.

Jocaste lucina (Nobili, 1901)

Coralliocaris lamellirostris Stimpson 1860, p 38; De Man 1902, p 842, Plate 26, Figure 55.

Coralliocaris lucina Nobili 1901, p 5; Borradaile 1917, p383; Kemp 1922, p 276, Figure 102; Barnard 1950, p 799, Figure 151i-m.

Focaste lucina: Holthuis 1952a, p 193-195, Figure 94 (partim); Patton 1966, p 278, Figure 3a; Bruce 1969a, p301, Figure 2; Bruce 1974b, p 199; Bruce 1979a, p 239; Bruce 1981b, p 89; Fransen 1994, p 110, Figure 64; Li 1997, p 233; Li 1998, p 222, Figures 12, 13; Li 2000, p 70, Figure 71; De Grave 2000, p 126.

\section{Material examined}

Loyalty Islands: ATELIER LIFOU, Lifou, Santal Bay, (i) between Huca Hutighé Islet and the shore, stn $1421,20^{\circ} 52.4^{\prime} \mathrm{S}, 167^{\circ} 08.5^{\prime} \mathrm{E}, 4 \mathrm{~m}$, coarse sand on flatstone, 26-27 November 2000, 1 ovig. O (MNHN-Na 15460); (ii) in front of Ngoni, stn 1457, 20 46.8'S, $167^{\circ} 02.75^{\prime} \mathrm{E}$, 5-10 m, dark overhang and boulders, 27 November 2000, 1 ovig. ㅇ (MNHN-Na 15459).

\section{Remarks}

Not previously recorded from Loyalty Islands. Associated with Acropora, rarely Pocillopora, Stylophora.

\section{Distribution}

Type locality: Eritrea. Also known from Egypt, Israel, Sudan, Yemen, Oman, Kenya, Zanzibar, Tanzania, Mozambique, Comoro Islands, Madagascar, Seychelles, La Réunion, Maldives, Sri Lanka, Andaman Islands, Nicobar Islands, Singapore, Vietnam, South China Sea, Indonesia, Papua New Guinea, Australia (Western Australia, Queensland), Coral Sea, Marianas Islands, New Caledonia, Loyalty Islands, Marshall Islands, Fiji, Cook Islands and Johnson Atoll.

\section{Kemponia agag (Kemp, 1922)}

(Figure 3)

Periclimenes (Ancylocaris) agag Kemp 1922, p 197, Figures 47-50, Plate VII, Figure 9. Periclimenes agag: Li 2000, p 150, Figure 181.

Kemponia agag: Bruce 2004, p 10.

\section{Material examined}

New Caledonia: (i) Senez Reef, $7 \mathrm{~m}$, coll. P. Bouchet, 7 September 1992, $1 \delta^{\hat{0}}$ (MNHNNa 14877); (ii) Ouano. scuba, 0.1 m, April 1995, 2 ovig. ơ (MNHN-Na 15810).

\section{Remarks}

Previously reported from New Caledonia (Nouméa) by Ledoyer (1984). 


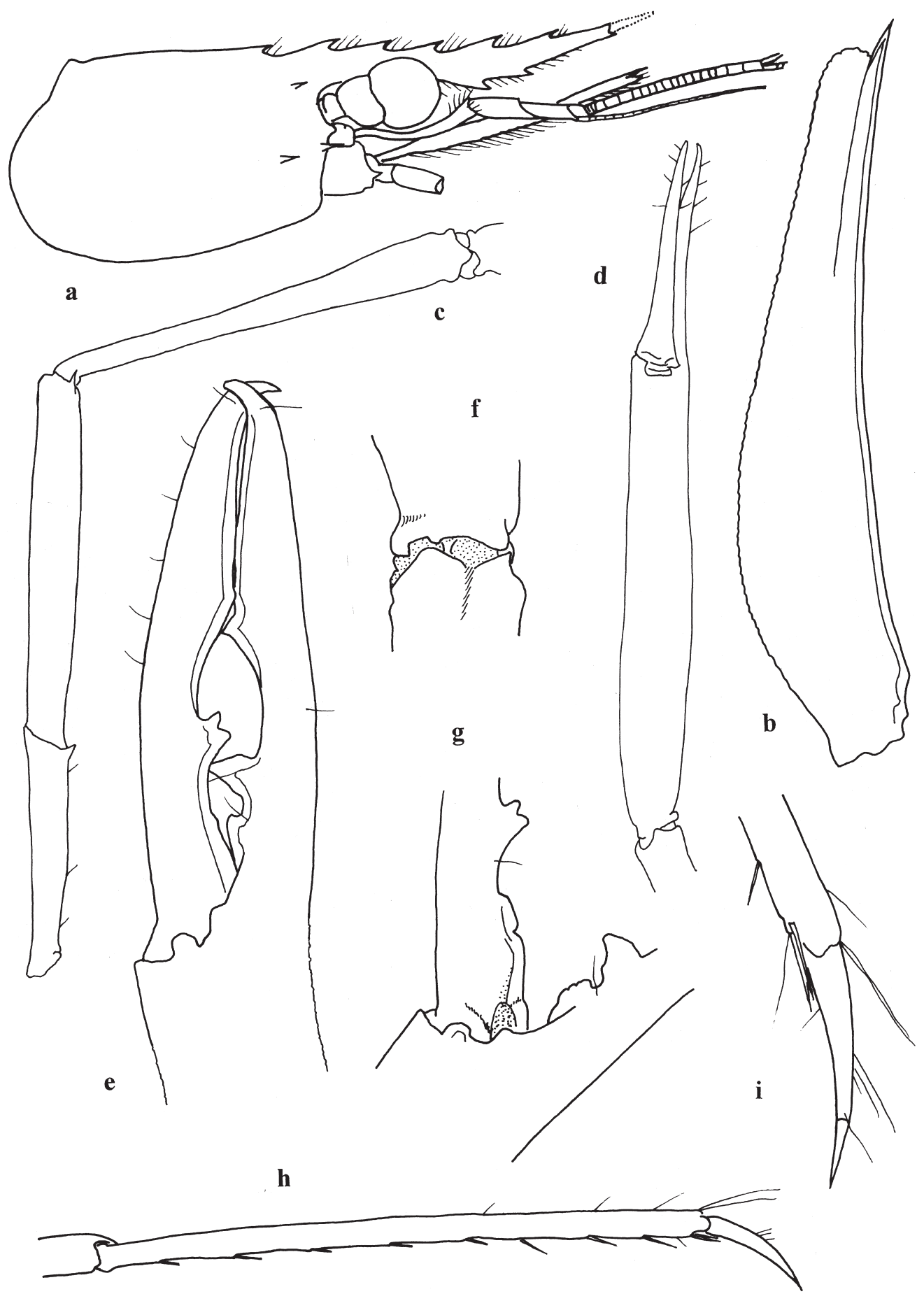

Figure 3. Kemponia agag (Kemp, 1922), male (MNHN-Na 14877). (a) Carapace and anterior appendages; (b) antennal scale; (c) second pereiopod, ischium, merus, and carpus; (d) same, chela; (e) same, fingers; (f) same, article of carpus and chela; (g) proximal fingers; (h) third pereiopod, propod and dactyl; (i) same, distal propod and dactyl. 


\section{Distribution}

Type locality: Port Blair, Andaman Islands. Also known from Red Sea, Australia (Queensland), New Caledonia and Marshall Islands.

Kemponia amymone (De Man, 1902)

Periclimenes amymone De Man 1902, p 829-833, Plate 25, Figure 53; Bruce 1991b, p 235; Chace and Bruce 1993, p 102; Li 2000, p 155, Figure 190; Davie 2002, p 323; Li and Liu 2004, p 90, Figure 1g-k.

Kemponia amymone: Bruce 2004, p 11.

\section{Material examined}

New Caledonia: (i) lagoon, Îlot Maitre, reef flat, scuba, 3 m, coll. C. Vadon, 29 August 1978, 1 ovig. \& (MNHN-Na 15834).

Remarks

The specimen has a rostral dentition of $1+7 / 3$ and has both second pereiopods. The species was previously recorded from New Caledonia by Bruce (1967b, 1991b) and Ledoyer (1984).

\section{Distribution}

Type locality: Ternate, Indonesia. Also known from the Nicobar Islands, Singapore, Vietnam, Philippines, Indonesia, Papua New Guinea, Australia (Western Australia, Northern Territory, Queensland), Solomon Islands (New Georgia Islands) New Caledonia, and Samoan Islands.

Kemponia anacanthus (Bruce, 1988)

Periclimenes anacanthus Bruce 1988a, p 105, Figures 1-5; Bruce and Coombes 1995, p 125, Figure 12a; Li 2000, p 156, Figure 191.

Kemponia anacanthus: Bruce 2004, p 12.

\section{Material examined}

New Caledonia: (i) stn LF3 “83”, $20^{\circ} 47.27^{\prime} \mathrm{S}, 167^{\circ} 07.34^{\prime} \mathrm{E}, 12 \mathrm{~m}$, on red algae, 27 November 1995, 1今̄, 2oㅇ (MNHN-Na 15905); (ii) lagoon, $20^{\circ} 42.15^{\prime} \mathrm{S}, 167^{\circ} 09.90^{\prime} \mathrm{E}$, scuba, $1 \mathrm{~m}$, on red algae, 28 November 1995, $1 \delta^{\widehat{A}}$ (juvenile?, both second pereiopods lost) (MNHN-Na 15909). Loyalty Islands: ATELIER LIFOU, Lifou, Santal Bay, (iii) near Kiki, stn $1411,20^{\circ} 47.6^{\prime} \mathrm{S}, 167^{\circ} 10.35^{\prime} \mathrm{E}, 4-8 \mathrm{~m}$, sand between coral heads, 13 November

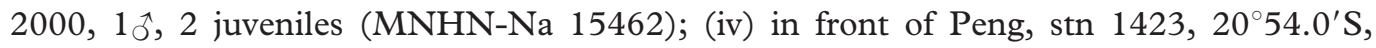
$167^{\circ} 07.3^{\prime} \mathrm{E}, 12 \mathrm{~m}$, sandy channels between coral heads, 14 November $2000,1 \%$ (MNHN$\mathrm{Na} 15461$ ); (v) between Cap Wekutr and Cap Wajez, stn $1455,20^{\circ} 56.8^{\prime} \mathrm{S}, 167^{\circ} 02.7^{\prime} \mathrm{E}$, slope, 15-20 m, 25 November 2000, 1 ovig. 우 (MNHN-Na 15463); (vi) between Huca 
Hutighé Islet and shore, stn $1421,20^{\circ} 52.4^{\prime} \mathrm{S}, 167^{\circ} 08.5^{\prime} \mathrm{E}, 4 \mathrm{~m}$, coarse sand on flat-stone, 27 November 2000, 1 ô (MNHN-Na 15464).

\section{Remarks}

Only the right second pereiopod of specimen (iv) and one of the juveniles of (iii) present, all other specimens lack their second pereiopods. The unarmed merus and carpus and the long carpus (much longer than palm) of second pereiopod of the specimens indicate they are identical to the present species. Not previously recorded from Loyalty Islands.

\section{Distribution}

Type locality: Queensland. Also known from Cobourg Peninsula (Australia), New Caledonia, and Loyalty Islands.

Kemponia andamanensis (Kemp, 1922)

Periclimenes (Ancylocaris) andamanensis Kemp 1922, p 204, Figures 54-57.

Periclimenes (Harpilius) andamanensis: Holthuis 1952a, p 79.

Periclimenes andamanensis: Bruce 1977c, p 269; Bruce 2003, p 229; Li 1996, p 229, Figure 7; Li 1997, p 238; Li 2000, p 156, Figure 192; Li 2001, p 81; Li 2004a, p 68; Li and Liu 2004, p 91, Figure 2.

Kemponia andamanensis: Bruce 2004, p 12.

Kemponia cf. andamanensis: Li et al. 2004, p 529, Figure 16.

\section{Material examined}

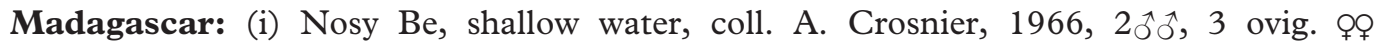
(MNHN-Na 15969); (ii) same, $1 \hat{\jmath}, 1 \propto$ (MNHN-Na 15967). New Caledonia: (iii) Station

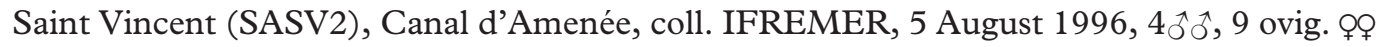
(MNHN-Na 15824); (iv) western coast, Ouano, trawl, $1 \mathrm{~m}$, seagrass, 1-5 m, 22 December 1998, $9 \hat{\jmath} \widehat{o}, 160$ (1 ovig.) (MNHN-Na 15828). Fiji: (v) Viti Levu, West Lagoon, SUVA 2, stn CP66, $37 \mathrm{~m}, 17^{\circ} 45.1^{\prime} \mathrm{S}, 177^{\circ} 13.7^{\prime} \mathrm{E}, 21$ October $1998,1{ }^{\jmath}, 1$ ovig. ㅇ (MNHN-Na 15465).

\section{Remarks}

Not previously recorded from Fiji and New Caledonia. The present record extends its bathymetric range to $37 \mathrm{~m}$ depth.

\section{Distribution}

Type locality: Andaman Islands. Also known from Madagascar, Indonesia, China, South China Sea, Japan, Australia (Queensland), New Caledonia, and Fiji. 
Kemponia darwiniensis (Bruce, 1987)

Periclimenes darwiniensis Bruce 1987, p 29, Figures 1-5; Li 2000, p 174, Figure 217.

Kemponia darwiniensis: Bruce 2004, p 13.

Material examined

New Caledonia: St Marie Bay, 14 m, scuba, coll. P. Bouchet, 4 January 1993, 1 ovig. $q$ (MNHN-Na 15911).

\section{Remarks}

This is the first record outside its type locality Darwin Harbour, Australia.

\section{Distribution}

Type locality: Darwin Harbour, Darwin, Northern Territory, Australia. Also known now from New Caledonia.

Kemponia elegans (Paulson, 1875)

Anchistia elegans Paulson 1875, p 113, Plate 17, Figure 1.

Periclimenes (Falciger) elegans: Borradaile 1917, p 371.

Periclimenes (Ancylocaris) elegans: Kemp 1922, p 215, Figures 60-62.

Periclimenes (Harpilius) elegans: Holthuis 1952a, p 81, Figure 31.

Periclimenes elegans: Bruce 1971a, p 7; Bruce 1983b, p 884; Fransen 1994, p 122; Bruce and Coombes 1995, p 129; Li 1997, p 238; Li 1998, p 222, Figures 14-17; Li 2000, p 178, Figure 225; De Grave 2000, p 135.

Kemponia elegans: Bruce 2004, p 14.

\section{Material examined}

New Caledonia: (i) Kuendu Bay, 0.5 m, coll. B. Richer de Forges, 5 May 1996, 1ో人, 1 ovig. o (MNHN-Na 15826); (ii) lagoon, Poingam, low tide, coll. B. Richer de Forges, 10 May 1997, $1 \hat{\sigma}($ MNHN-Na 15829). Fiji: (iii) MUSORSTOM 10, south of Vitu Levu, flat reef, low tide, 3 August 1998, $1 \widehat{o}$ (MNHN-Na 15467).

\section{Remarks}

Not previously recorded from Fiji and New Caledonia.

\section{Distribution}

Type locality: Red Sea. Also known from Egypt, Saudi Arabia, Yemen, Kenya, Zanzibar, Tanzania, Madagascar, Seychelles, Kuweit, Laccadive Islands (Minikoi), India, Sri Lanka, Andaman Islands, Nicobar Islands, Singapore, South China Sea, Ryukyu Islands, Japan, Philippines, Indonesia, Papua New Guinea, Timor Sea (Hibernia Reef), Australia (Western Australia, Northern Territory, Queensland), Caroline Islands, Solomon Islands, New Caledonia, Marshall Islands, Fiji, French Polynesia (Society Islands). 
Kemponia ensifrons (Dana, 1852)

Anchistia ensifrons Dana 1852, p 25.

(Figures 4, 5)

Periclimenes (Falciger) ensifrons: Borradaile 1917, p 367, 370.

Periclimenes ensifrons: Chace and Bruce 1993, p 111; Li 2000, p 180.

Kemponia ensifrons: Bruce 2004, p 15.

\section{Material examined}

New Caledonia: MONTROUZIER, Touho, sandy islet, scuba, coll. B. Richer de Forges, scuba, 7 September 1993, 1 ovig. o (MNHN-Na 14891).

\section{Remarks}

Not previously reported from New Caledonia. The species is possibly synonymous with Kemponia grandis (Stimpson) (Bruce 2004, p 15).

\section{Distribution}

Type locality: Balabac Strait, North Borneo. Also reported from the Egyptian Red Sea, Zanzibar, Comoro Islands, Seychelles, Burma, China, Papua New Guinea, New Caledonia, Marshall Islands, and French Polynesia (Tuamotu Islands).

\section{Kemponia grandis (Stimpson, 1860)}

Anchistia grandis Stimpson 1860, p 39.

Periclimenes grandis: Borradaile 1898, p 382; Chace and Bruce 1993, p 112; Li 2000, p 186,

Figure 235; Davie 2002, p 327; Li and Liu 2004, p 93, Figure 4; Li 2004a, p 69.

Kemponia grandis: Bruce 2004, p 16; Li et al. 2004, p 530.

\section{Material examined}

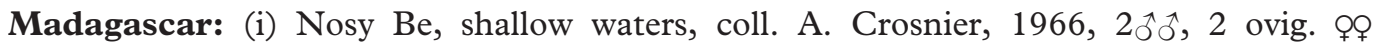
(MNHN-Na 15956). New Caledonia: (ii) MONTROUZIER, Touho, Grand Récif, Mangalia, intertidal zone, coll. B. Richer de Forges, 15 October 1993, 1 ovig. o (MNHNNa 14893); (iii) Ouano reef flat, low tide, coll. B. Richer de Forges, 26 April 1998, 1 ovig. ㅇ (MNHN-Na 15813). Loyalty Islands: ATELIER LIFOU, Lifou, (iv) Santal Bay: between Huca Hutighé Islet and the shore, stn $1421,20^{\circ} 52.4^{\prime} \mathrm{S}, 167^{\circ} 08.5^{\prime} \mathrm{E}, 4 \mathrm{~m}$, coarse sand on flatstone, 26-27 November 2000, 1 đิ (MNHN-Na 15471).

\section{Remarks}

Previously reported from Madagascar by Bruce (1978a). Not previously recorded from New Caledonia and Loyalty Islands, although it is one of the commonest and most widely distributed Indo-West Pacific pontoniine species.

\section{Distribution}

Type locality: Amami O Shima, Ryukyu Islands. Also known from Egypt, Israel, Djibouti, Aden, Kenya, Zanzibar, Tanzania, Mozambique, Comoro Islands, Madagascar, Seychelles, 
Sri Lanka, Burma, Malaya, Singapore, Japan, Indonesia, Australia (Northern Territory, Queensland), New Caledonia, Loyalty Islands, Marshall Islands, Tuvalu, and Fiji.

Kemponia kororensis (Bruce, 1977)

Periclimenes kororensis Bruce 1977d, p 33, Figures 1-4; Bruce and Svoboda 1984, p 94, Figures 5, 6; Li 2000, p 201, Figure 258.

Kemponia kororensis: Bruce 2004, p 16.

\section{Material examined}

Philippines: MUSORSTOM II, shore station, stn 11, opposite Mactan Marine Station, scuba, 5-18 m, with fungiid coral, 9 December 1980, 1 ^ै (MNHN-Na 15961).

\section{Remarks}

The single specimen with rostral formula of $2+5 / 4$, second to fourth dorsal teeth are grouped over orbital region, but not forming a crest as in the type. Both second pereiopods

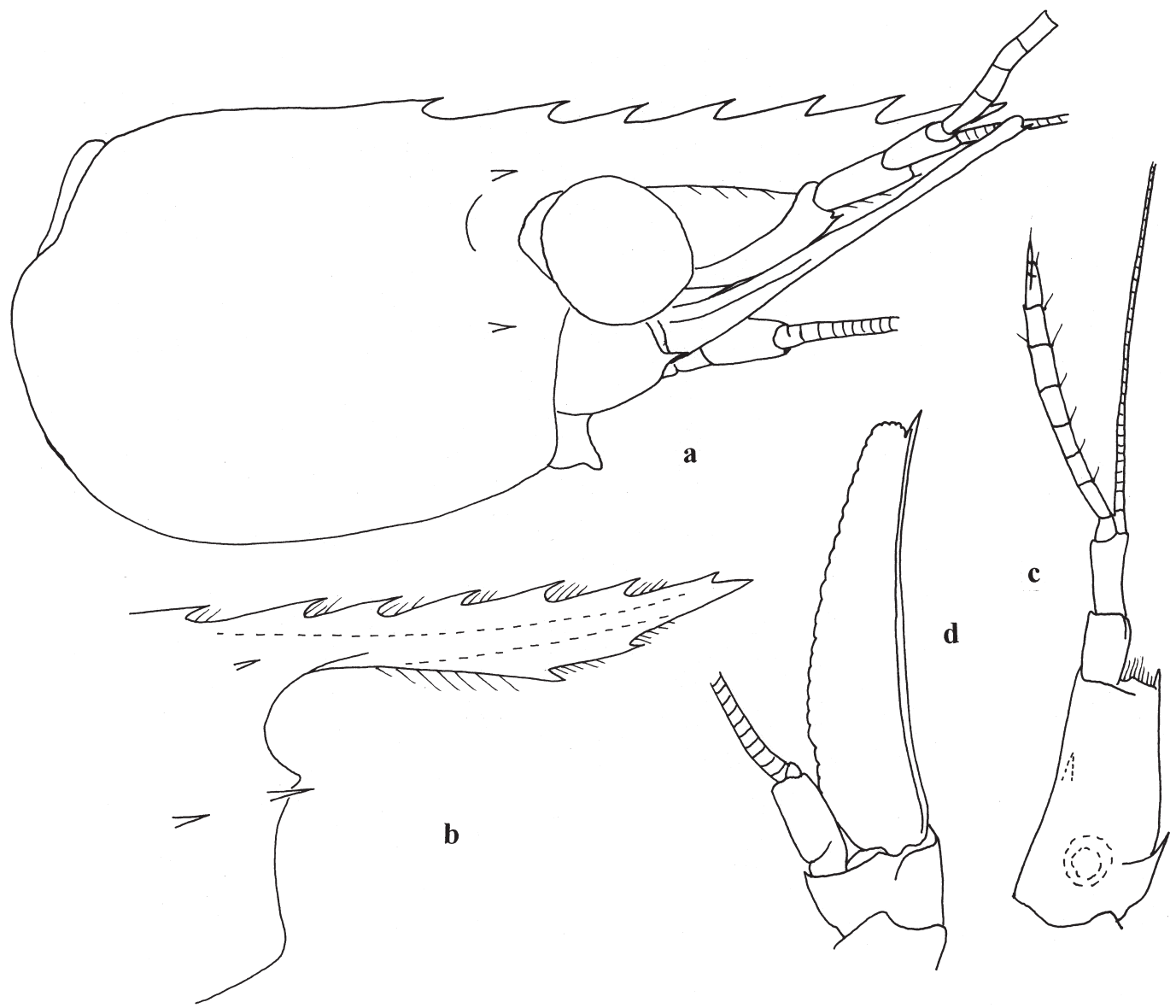

Figure 4. Kemponia ensifrons (Dana, 1852), ovigerous female (MNHN-Na 14891). (a) Carapace and anterior appendages; (b) anterior carapace; (c) antennule; (d) antenna. 

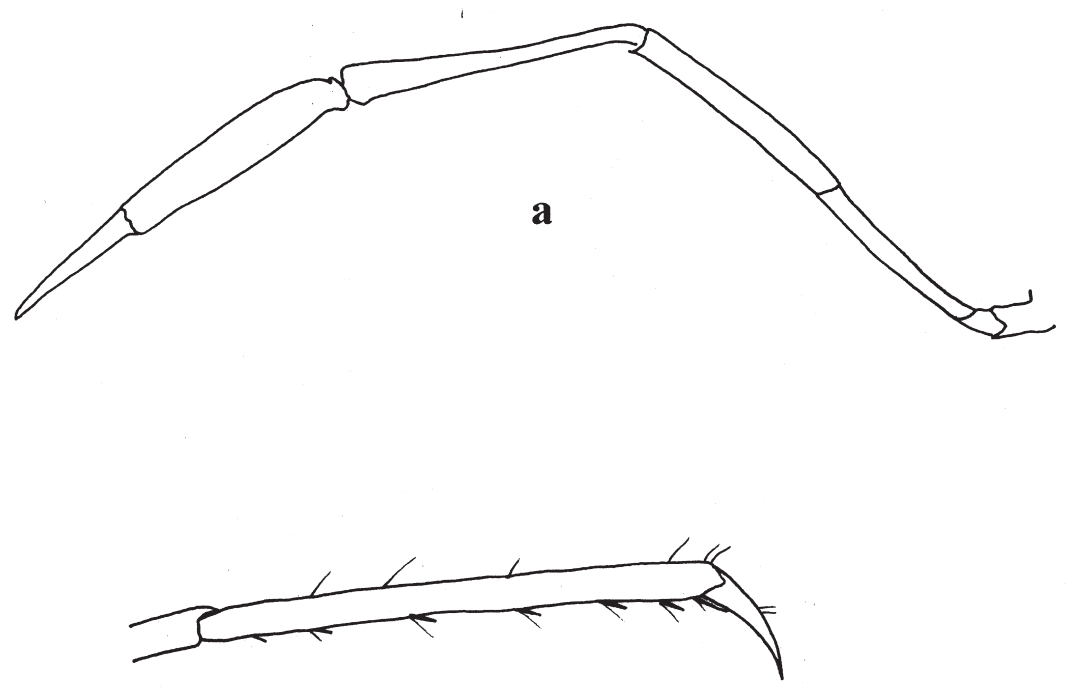

c

b
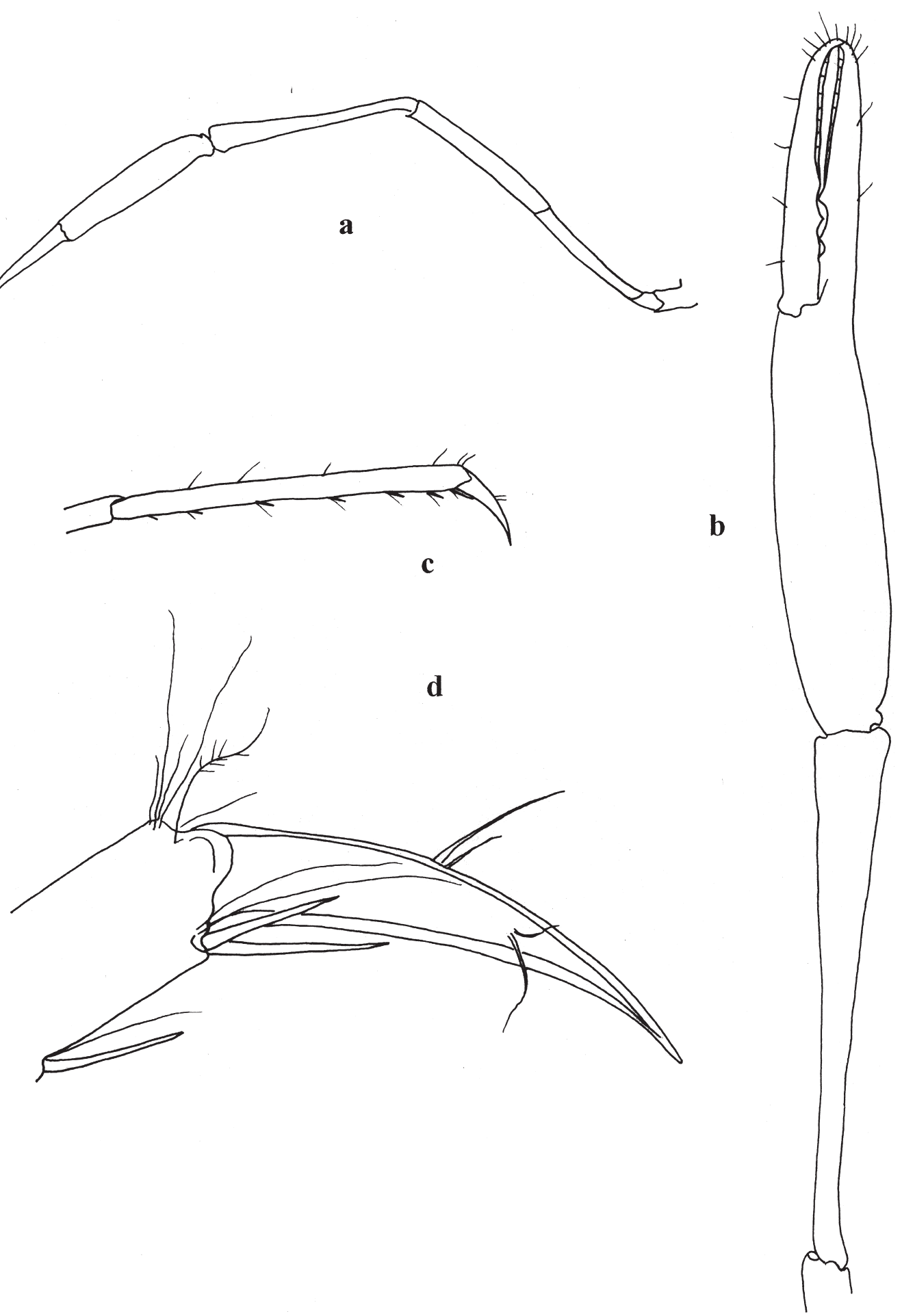

Figure 5. Kemponia ensifrons (Dana, 1852), ovigerous female (MNHN-Na 14891). (a) Second pereiopod; (b) same, chela and carpus; (c) third pereiopod, propod and dactyl; (d) same, distal propod and dactyl. 
lost. Ambulatory pereiopods with flexor margin of propod unarmed except for the distoventral spine. Previously recorded from Philippines by Bruce and Svoboda (1984) from Cebu.

\section{Distribution}

Type locality: Koror, Palau Islands, Caroline Islands. Also known from Malaysia, Japan, Philippines, Indonesia, Papua New Guinea, Australia (Queensland), and Marshall Islands.

Kemponia lacertae (Bruce, 1992)

Periclimenes lacertae Bruce 1992, p 46, Figures 1-6; Li 2000, p 203, Figure 260.

Kemponia lacertae: Bruce 2004, p 17.

\section{Material examined}

Loyalty Islands: ATELIER LIFOU, Lifou, Chateaubriand Bay: Wé Beach, stn 1474, $20^{\circ} 54.8^{\prime} \mathrm{S}, 167^{\circ} 16.1^{\prime} \mathrm{E}, 0-3 \mathrm{~m}$, fine sand and heads of Porites, 10 and 21 November 2000, 1 今ै (MNHN-Na 15473).

\section{Remarks}

The single specimen with the rostrum inclined slightly upwards, instead of horizontal. Not previously recorded from Loyalty Islands.

\section{Distribution}

Type locality: Chinaman's Ridge, Mrs Watson's Bay, Lizard Island, Queensland, Australia, and Liang Island; Hansa Bay, Papua New Guinea. Now also known from Loyalty Islands.

\section{Kemponia nilandensis (Borradaile, 1915)}

Periclimenes (Falciger) nilandensis Borradaile 1915, p 211; Borradaile 1917, p 324, 372, Plate 54, Figure 13.

Periclimenes nilandensis: Bruce 1978a, p 222, Figures 8, 9; Chace and Bruce 1993, p 118;

Bruce 1996, p 237; Li 2000, p 214, Figure 278; Davie 2002, p 330.

Kemponia nilandensis: Bruce 2004, p 18; Li et al. 2004, p 531.

\section{Material examined}

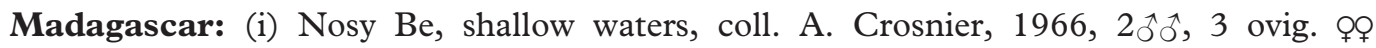
(MNHN-Na 15955). La Réunion: (ii) MD32, stn CP43, $21^{\circ} 20.7^{\prime} \mathrm{S}, 55^{\circ} 26.9^{\prime} \mathrm{E}, 73-77 \mathrm{~m}$,

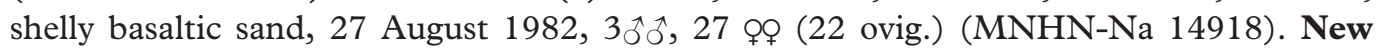
Caledonia: (iii) MONTROUZIER, Touho Channel, $35 \mathrm{~m}$, from antipatharians, coll. B.

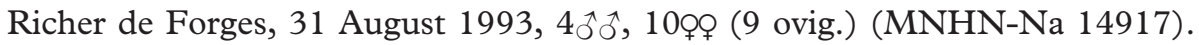


Remarks

Previously recorded from Madagascar (Nosy Bé) by Bruce (1978a). Not previously recorded from La Réunion. Reported from Anaa Reef, New Caledonia by Bruce (1996).

\section{Distribution}

Type locality: South Nilandu Atoll, Maldives. Also known from Kenya, Zanzibar, Madagascar, Maldives, South China Sea, Indonesia, Australia (Northern Territory, Queensland), and New Caledonia; to depths of $133 \mathrm{~m}$.

Kemponia seychellensis (Borradaile, 1915)

Periclimenes (Falciger) seychellensis Borradaile 1915, p 212.

Periclimenes (Ancylocaris) seychellensis: Kemp 1922, p 176, Figures 34, 35, Plate 6, Figure 7. Periclimenes (Harpilius) seychellensis: Holthuis 1952a, p 66, Figure 25; Ledoyer 1984, p 33, Figure 14.

Periclimenes seychellensis: Bruce 1971a, p 8; Bruce 1991b, p 238, Figure 8; Li 2000, p 235, Figure 313.

Kemponia seychellensis: Bruce 2004, p 19.

\section{Material examined}

New Caledonia: (i) lagoon, Îlot Maitre, $22^{\circ} 19.70^{\prime} \mathrm{S}, 166^{\circ} 23.30^{\prime} \mathrm{E}, 10 \mathrm{~m}$, on seagrass, scuba, coll. I. Takeuchi, 6 November 1995, 3 ovig. ơ (MNHN-Na 15904); (ii) Rocher à la Voile, $22^{\circ} 18.23^{\prime} \mathrm{S}, 166^{\circ} 26.15^{\prime} \mathrm{E}, 0.5 \mathrm{~m}$, scuba, 18 November $1995,1{ }^{\wedge}$ (MNHN-Na 15906); (iii) lagoon, Ricaudy reef flat, low tide, coll. B. Richer de Forges, 22 June 1997,

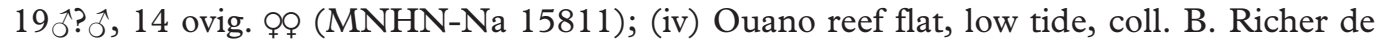
Forges, 26 April 1998, 4 ovig. o̊ (MNHN-Na 15830).

\section{Remarks}

The tubercle on the dorsal surface of eyestalk makes the identification of the species simple. The species has been previously recorded from New Caledonia by Ledoyer (1984) and Bruce (1991b).

\section{Distribution}

Type locality: Praslin, Seychelles. Also reported from Kenya, Zanzibar, Tanzania, Mozambique, Madagascar, Seychelles, Pakistan, India, Andaman Islands, Singapore, China, Japan, Indonesia, Papua New Guinea, Australia (Western Australia, Northern Territory, Great Barrier Reef), and New Caledonia. 
Kemponia cf. suvadivensis (Borradaile, 1915)

(Figure 6)

Periclimenes (Falciger) suvadivensis Borradaile 1915, p 212; Borradaile 1917, p 375, Plate 55, Figure 16.

Periclimenes suvadivensis: Li 2000, p 239, Figure 317; Davie 2002, p 332.

Kemponia suvadivensis: Bruce 2004, p 19.

\section{Material examined}

New Caledonia: west coast of Le Cap, in mangroves, coll. B. Richer de Forges, 2 December 1992, 10ิ, 2 ovig. 우 (MNHN-Na 14926).

\section{Remarks}

The specimens were collected with Palaemon sp. All the specimens lack second pereiopods, so the identification must be considered as provisional. Not previously recorded from New
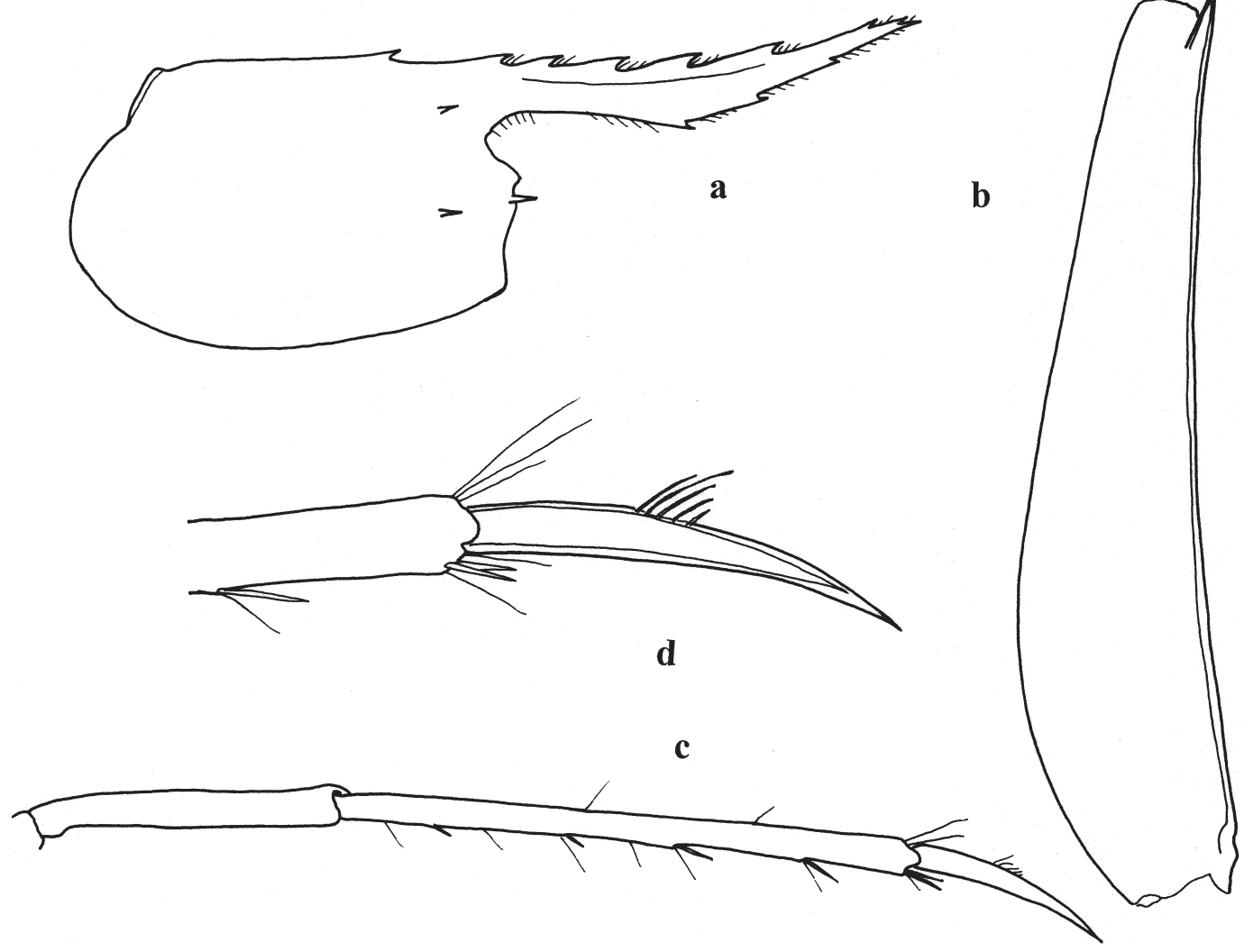

d

b

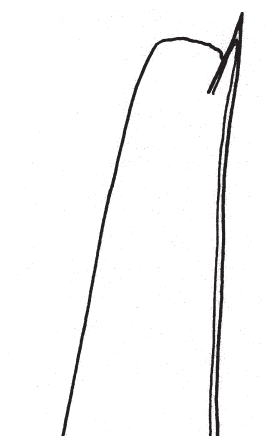

Figure 6. Kemponia cf. suvadivensis (Borradaile, 1915), ovigerous female (MNHN-Na 14926). (a) Carapace; (b) antennal scale; (c) third pereiopod, carpus, propod, and dactyl; (d) same, distal propod and dactyl. 
Caldedonia. The specimens have rostral dentition of $1+7 / 3$, the rostrum greatly exceeds the antennular peduncle, particularly in the male, is slender, about 1.35 times the carapace length, as opposed to 1.15 times in the $K$. suvadivensis type material, the scaphocerite lamella is subquadrate distally and well exceeded by the distolateral tooth. The third pereiopod dactyl is about 9.0 times longer than the basal width and about 0.36 of the propod length, as opposed to 0.2 times in the type material; the proportion of length to breadth of the propod are similar but the present material has fewer ventral spines, four as opposed to six.

\section{Distribution}

Type locality: Suvadiva Atoll, Maldives. Also reported from Australia (Northern Territory) and New Caledonia.

Kemponia tenuipes (Borradaile, 1898)

Periclimenes tenuipes Borradaile 1898, p 384; Bruce 1978b, p 261, Figures 6A, 7; Bruce 1991b, p 240; Li 2000, p 240, Figure 319.

Periclimenes (Ancylocaris) tenuipes: Kemp 1922, p 220, Plate 8, Figure 11.

Periclimenes (Harpilius) tenuipes: Holthuis 1952a, p 84.

Kemponia tenuipes: Bruce 2004, p 19.

\section{Material examined}

New Caledonia: (i) Marie Bay, $14 \mathrm{~m}$, scuba, coll. P. Bouchet, 4 January 1993, 1今̄, 2ợ (1 ovig.) (MNHN-Na 15918). Loyalty Islands: ATELIER LIFOU, Lifou, Santal Bay, (ii) Cap Lefèvre, stn $1469,20^{\circ} 54.2^{\prime} \mathrm{S}, 167^{\circ} 00.4^{\prime} \mathrm{E}, 70-130 \mathrm{~m}$, dredge, 22-23 November 2000, 1 ovig. ㅇ (MNHN-Na 15591); (iii) Peng, stn 1464, $20^{\circ} 54.5^{\prime} \mathrm{S}, 167^{\circ} 05.9^{\prime} \mathrm{E}, 30-50 \mathrm{~m}, 14$ November 2000, $1 \hat{\jmath}, 1$ ( $(\mathrm{MNHN}-\mathrm{Na}$ 15589); (iv) north of Cape Aimé Martin (=Acadro), stn $1450,20^{\circ} 45.8^{\prime} \mathrm{S}, 167^{\circ} 01.65^{\prime} \mathrm{E}, 27-31 \mathrm{~m}$, washings, 17 and 21 November 2000,1 \% (MNHN-Na 15624). Fiji: (v) SUVA 2. Viti Levu, West Lagoon, Stn CP 66, 17 $^{\circ} 45.1^{\prime}$ S, $177^{\circ} 13.7^{\prime} \mathrm{E}, 37 \mathrm{~m}$, coll. Richer-ORSTOM, 21 October 1998, 1 ovig. ㅇ (MNHN-Na 15614).

\section{Remarks}

Not previously recorded from Loyalty Islands and Fiji. Previously recorded from New Caledonia by Bruce (1991b).

\section{Distribution}

Type locality: New Britain, Papua New Guinea. Also reported from Jordan, Kenya, Zanzibar, Madagascar, Seychelles, La Réunion, Maldives, Sri Lanka, Andaman Islands, 
China, Japan, Philippines, Indonesia, Papua New Guinea, Timor Sea (Hibernia Reef), Australia (Northern Territory, Queensland), Caroline Islands, New Caledonia, Marshall Islands, and Fiji.

Manipontonia psamathe (De Man, 1902)

Urocaris psamathe De Man 1902, p 816-822, Plate 25, Figure 51.

Periclimenes (Ancylocaris) psamathe: Kemp 1922, p 173.

Periclimenes (Harpilius) psamathe: Holthuis 1952a, p 61, Figure 23.

Periclimenes psamathe: Bruce 1991b, p 238, Figures 1a, 3a; Chace and Bruce 1993, p 120;

Bruce 1996, p 238; Li 2000, p 229, Figure 304; Davie 2002, p 331; Li et al. 2004, p 545,

Figure 31.

Manipontonia psamathe: Bruce et al. 2005, p 6, Figures 1-3.

\section{Material examined}

Madagascar: (i) SE coast, Ste Luce, trawl, shelly sand, $50 \mathrm{~m}$, coll. A. Crosnier, October 1958, 1 ิ̂, 2 ovig. ợ (MNHN-Na 12904); (ii) Nosy Be, shallow waters, coll. A. Crosnier, 1966, 1 ô, 2 ovig. ọ, 3 spms (MNHN-Na 15952). New Caledonia: (iii) Iré Bay, scuba, night dive, $10 \mathrm{~m}$, coll. P. Laboute, 7 June 1990, 6 ô ô, 7ọ (6 ovig.) (MNHN-Na 12905). MONTROUZIER, (iv) Touho Channel, $48 \mathrm{~m}$, scuba, coll. B. Richer de Forges, 31 August 1993, 1 ovig. o (MNHN-Na 14922); (v) same, 35 m, from antipatharians, 31 August 1993, 2 ovig. o̊, 1 juvenile (MNHN-Na 14921); (vi) same, 1 ovig. ㅇ (MNHN-Na 14923); (vi) same, $35 \mathrm{~m}, 1 \hat{\jmath}$ (MNHN-Na 15902).

Hosts

(i) Hydroids and sponges; (iv) (v) antipatharians.

\section{Remarks}

First recorded from New Caledonia at Nouméa by Bruce (1970a). Previously recorded from Madagascar by Bruce (1977c, 1978a). The association of (i) with sponges is probably accidental.

\section{Distribution}

Type locality: Ternate, Indonesia. Also known from Kenya, Zanzibar, Tanzania, Madagascar, Seychelles, Maldives, Chagos Islands, Thailand, Malaya, Singapore, China, Japan, Philippines, Indonesia, Papua New Guinea, Australia (Western Australia, Northern Territory, Queensland), Caroline Islands, New Caledonia, and Marshall Islands. 
Mesopontonia brevicarpus sp. nov.

(Figures 7, 8)

\section{Material examined}

La Réunion: MD 32, stn DS173, $20^{\circ} 51.5^{\prime} \mathrm{S}$, $55^{\circ} 36.87^{\prime} \mathrm{E}, 270 \mathrm{~m}, 8$ September 1982,1

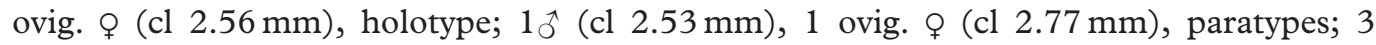
juveniles (MNHN-Na 14824).

\section{Description}

A small-sized pontoniine shrimp of slender, subcylindrical body shape, closely resembling other species of the genus, such as M. gracilicarpus Bruce, 1990 and M. verrucimanus Bruce, 1996.

Rostrum well developed, horizontal, compressed, extending anteriorly near to the end (ovig. O) or to the proximal third ( $(\hat{)})$ of distal segment of antennular peduncle, about 0.9 of carapace length, dorsal carina well developed, posteriorly elevated, dorsal margin convex, with eight evenly distributed acute teeth, first tooth with (ovig. o) or without ( $\left.\hat{\jmath}^{\prime}\right)$ basal suture, situated behind posterior orbital margin, distal tooth minute, lateral carinae

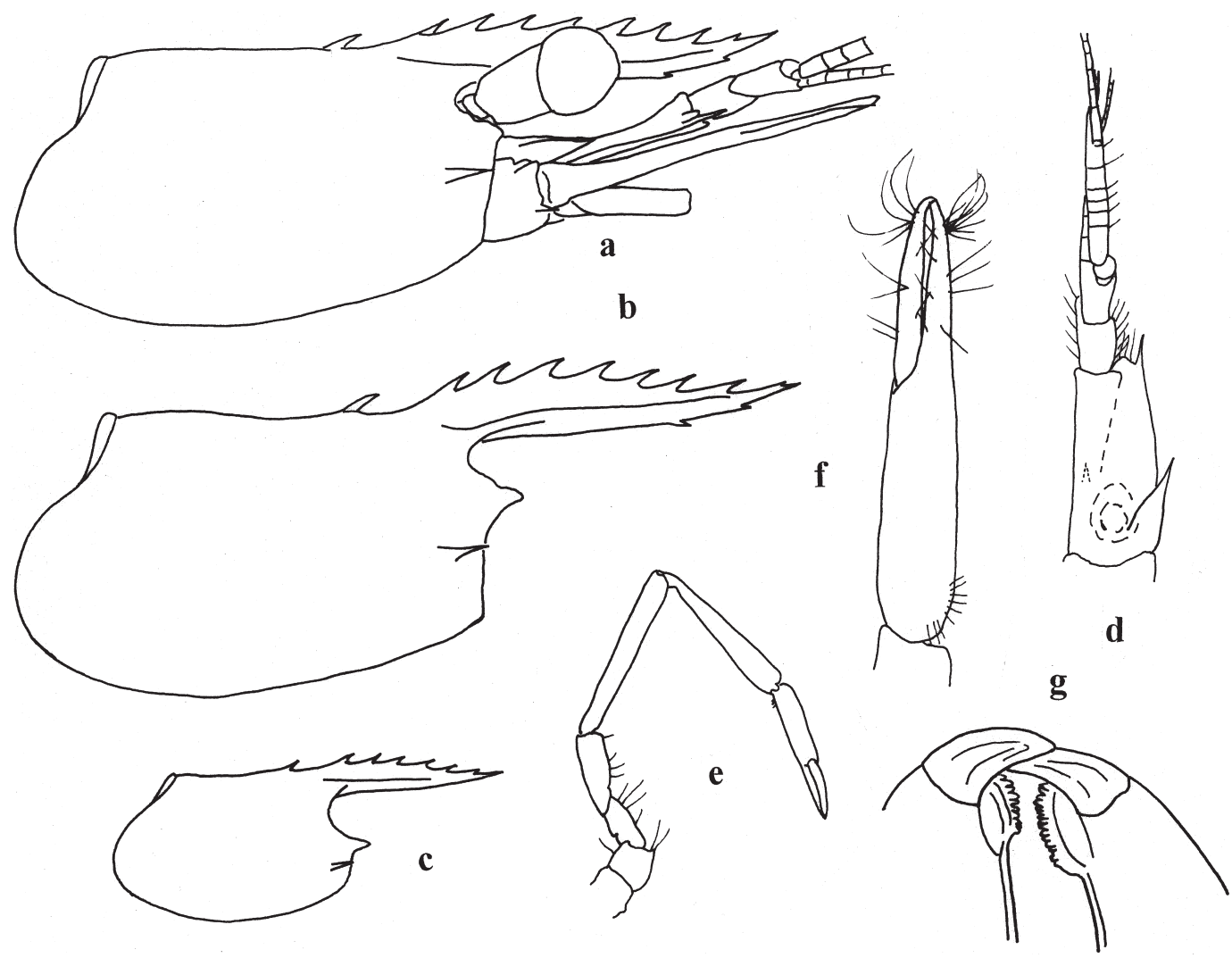

Figure 7. Mesopontonia brevicarpus, new species. (a, d-g) Holotype ovigerous female; (b) paratype male; (c) juvenile (MNHN-Na 14824). (a) Carapace and anterior appendages; (b, c) carapace; (d) antennule; (e) first pereiopod; (f) same, chela; ( $\mathrm{g}$ ) same, apexes of fingers. 


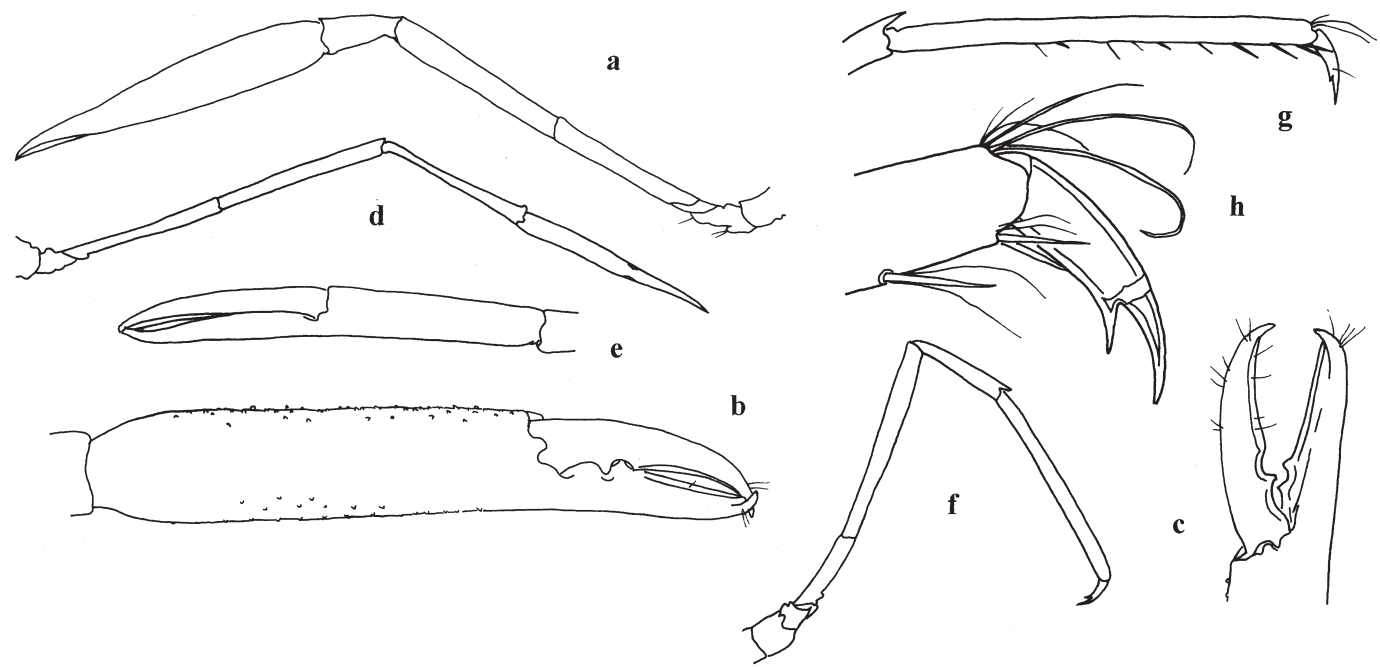

Figure 8. Mesopontonia brevicarpus, new species, holotype ovigerous female (MNHN-Na 14824). (a) Major second pereiopod; (b) same, chela; (c) same, fingers; (d) minor second pereiopod; (e) same, chela; (f) third pereiopod; (g) same, propod and dactyl; (h) same, distal propod and dactyl.

obsolete, ventral carina feebly developed, margin slightly convex. Carapace smooth, glabrous, with epigastric spine at anterior 0.3 of carapace length, basal suture distinct, supraorbital and antennal spines absent, inferior orbital angle produced, hepatic spine well developed, slender, acute, reaching or extending to anterior margin of carapace, at about 0.12 of carapace length, well below level of inferior orbital angle, anterolateral angle of branchiostegite bluntly rounded. Abdomen and caudal fan without special features (the ovig. o holotype lacks the caudal fan), as in M. gracilicarpus.

Antennae as in $M$. gracilicarpus.

Eye with well-developed large, globular, pigmented cornea, diameter about 0.23 of carapace length.

Mouthparts mainly undissected. Third maxilliped without exopod, ischiomerus and basis feebly separated, with a rudimentary arthrobranch.

First pereiopod with finger about 0.7 of palm length, tips hooked, cutting edge entire except convex subapically with fine pectinated serrates; carpus about 1.1 times chela length, 0.9 of merus length, coxa with small ventromedial process.

Second pereiopods well developed, markedly unequal, dissimilar. Major pereiopod with chela about 1.0-1.1 of carapace length, palm subcylindrical, 3.9 times longer than deep, covered with uniformly distributed small blunt tubercles, many with short simple setae distally, fingers about 0.5 of palm length, dactyl slender, about 4.0 times longer than proximal depth, tapering distally, with acute hooked tip, cutting edge with distal half sharp, with one low acute tooth at proximal 0.3 and a notch at proximal 0.38 of the cutting length, without dorsolateral flange; fixed finger with two acute teeth at proximal 0.25 and 0.38 on the cutting edge; carpus short, stout, unarmed, about 0.34 of palm length, sparsely tuberculate, about 2.0 times longer than distal width, merus about 0.85 of palm length, 7.0 times longer than wide, uniform, smooth, unarmed; ischium about 0.9 times merus length, 0.73 of palm length, 7.0 times longer than distal width, smooth, unarmed; basis and coxa without special features. Minor pereiopod with chela about 0.7 of carapace length, 0.95 of 
major chela palm length, palm subcylindrical, smooth, about 4.0 times longer than distal width, slightly tapering proximally, fingers subequal to palm, slender, with small hooked tips, cutting edges distally sharp, entire; carpus slender, about 0.75 of chela length, 8.0 times longer than distal width, smooth, unarmed; merus about 1.1 times carpus length, 11.0 times longer than distal width, subuniform, unarmed; basis and coxa without special features.

Ambulatory pereiopods slender. Third pereiopod with propod about 0.7 of carapace length, 17 times longer than wide, uniform, with a pair of long and slender distoventral spines, ventral border with similar spinules, size decreasing proximally, with long setae distodorsally; dactyl about 0.17 of propod length, slender, biunguiculate, with clearly demarcated unguis, about 3.3 times longer than proximal width, 0.70 of corpus length, corpus 2.3 times longer than proximal depth, compressed.

\section{Measurements ( $\mathrm{mm}$ )}

Carapace length, 2.53-2.77; carapace and rostrum, 4.75-4.81; second pereiopod, major chela, 2.75; minor chela, $1.74 . / \mathrm{p}>$

\section{Systematic position}

The present species is closely related to M. gracilicarpus Bruce, 1990; it can be distinguished from the latter by the tuberculate major second pereiopod chela, relatively shorter carpus of minor second pereiopod ( 0.75 of chela length), and the hepatic spine on carapace reaching the anterior margin of carapace. In $M$. gracilicarpus, the major second pereiopod chela smooth, the carpus of minor second pereiopod 1.5 times chela length, and the hepatic spine not reaching to the anterior margin of carapace. Mesopontonia brevicarpus shares the tuberculate major chela of second pereiopod with $M$. verrucimanus Bruce, 1996. It can be immediately distinguished from that species by the biunguiculate dactyls of ambulatory pereiopods.

\section{Etymology}

From brevis (Latin), short; carpus (Latin), wrist, with reference to the short carpus of major second pereiopod.

\section{Remarks}

With the addition of the new species, there are now seven species in the genus Mesopontonia, including the unnamed taxon, Mesopontonia sp. Bruce, 1996. The key to Mesopontonia species provided by Bruce (1996) can be modified as following:

3. Second pereiopods markedly unequal . . . . . . . . . . . . . 3'

- Second pereiopods at most moderately unequal; carpus of minor second pereiopod shorter than chela . . . . . . . . . . . . . . . . . . . 4

3'. Palm of major second pereiopod tuberculate; carpus of minor second pereiopod shorter than chela; R. $1+8 / 2$. . . . . . . . . M. brevicarpus sp. nov.

- Palm of major second pereiopod smooth; carpus of minor second pereiopod about 1.5 times length of chela; R. 1+8/2 . . . . . . M. gracilicarpus Bruce, 1990 
Mesopontonia gracilicarpus Bruce, 1990

Mesopontonia gracilicarpus Bruce 1990a, p 202-211, Figures 34-37, 391, m; Bruce 1991a, p 391, Figure 64; Li 2000, p 76, Figure 76.

\section{Material examined}

New Caledonia: (i) SMIB 8, Azteque Bank, stn DW181, 23⒘7'S, $168^{\circ} 04.8^{\prime} \mathrm{E}, 311-$ $330 \mathrm{~m}, 31$ January 1993, 1 ovig. \& (MNHN-Na 14825); (ii) BATHUS 4, stn CP922, $18^{\circ} 48.04^{\prime} \mathrm{S}, 163^{\circ} 18.58^{\prime} \mathrm{E}, 600 \mathrm{~m}, 6$ August 1994, 1 \% (MNHN-Na 15966); (iii) HALIPRO 2, Norfolk Ridge, stn BT70, 24 ${ }^{\circ} 46^{\prime} \mathrm{S}, 168^{\circ} 09^{\prime} \mathrm{E}, 226-238$ m, 20 November 1996, 1 ovig. $q$ (MNHN-Na 15974); (iv) NORFOLK 1, Antigonia Bank, stn CP1714, 23⒉' $168^{\circ} 03^{\prime} \mathrm{E}, 257-269 \mathrm{~m}, 26$ June 2001, $1 \widehat{\jmath}$ (MNHN-Na 15971).

\section{Remarks}

The single specimen of (i) is in poor condition, with the major second pereiopod only, damaged, lacking the fingers, sixth abdominal segment and caudal fan and left fifth and right third and fourth pereiopods missing. The specimen (ii) with rostral formula $1+11 / 3$, palm of major second chela covered with distinct fine tubercles. Specimen (iii) damaged, both second pereiopods lost, rostrum broken. The specimen (iv) with rostral formula 1+9/ 2, right (?minor) second pereiopod lost.

\section{Distribution}

Type locality: New Caledonia, $22^{\circ} 56^{\prime} \mathrm{S}, 167^{\circ} 14^{\prime} \mathrm{E}$.

Metapontonia fungiacola Bruce, 1967

Metapontonia fungiacola Bruce 1967a, p 24-32, Figures 10-12; Li 2000, p 78, Figure 79.

\section{Material examined}

New Caledonia: MONTROUZIER, Touho, scuba, sand islet, coll. B. Richer de Forges, 7 September 1993, 1Q (MNHN-Na 14826).

\section{Remarks}

Not previously reported from New Caledonia and, outside the Indian Ocean, known only from the Ryukyu Islands. The single specimen, which has both second pereiopods, agrees well with previous descriptions. The host was not recorded, but the species is usually associated with fungiid corals.

\section{Distribution}

Type locality: Pamanzi Reef, Mayotte, Comoro Islands. Also known from Kenya, Tanzania, Seychelles, La Réunion and Ryukyu Islands. 
Palaemonella crosnieri Bruce, 1978

Palaemonella crosnieri Bruce 1978a, p 210, Figures 2-4; Li 2000, p 101, Figure 108.

\section{Material examined}

Loyalty Islands: ATELIER LIFOU, Lifou, Santal Bay, (i) east of Santal Bay: Mepinyo,

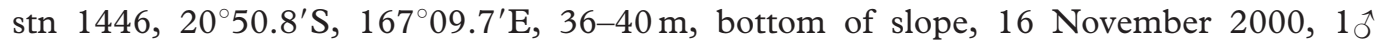
(MNHN-Na 15475); (ii) west of Easo Point, stn $1451,20^{\circ} 47.3^{\prime} \mathrm{S}, 167^{\circ} 06.8^{\prime} \mathrm{E}, 10-21 \mathrm{~m}$, coral heads, 19 November 2000, 1 ( (MNHN-Na 15476); (iii) between Cap Mande and Cap Lefèvre (=Nem), stn 1452, 20 $54.6^{\prime} \mathrm{S}, 167^{\circ} 02.1^{\prime} \mathrm{E}, 2-25 \mathrm{~m}$, scuba, 20 and 22 November 2000, $2 \hat{\jmath}$ (MNHN-Na 15477); (iv) between Cap Wekutr and Cap Wajez, stn

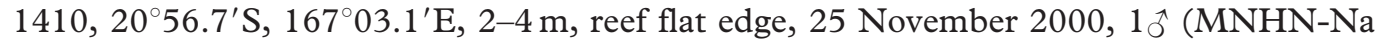
15474).

\section{Remarks}

The specimen (i) lacks the right pereiopod 1 and 2, with a regenerative left second pereiopod, and the rostrum broken and the part anterior to orbital margin lost. Previously only known from the type locality, Îles Glorieuses, $11^{\circ} 28.1^{\prime} \mathrm{S}, 47^{\circ} 21.1^{\prime} \mathrm{E}\left(27^{\circ} 21.1^{\prime} \mathrm{E}\right.$ in the original reference must be a mistake). The present records extend the bathymetric range to $40 \mathrm{~m}$ depth.

\section{Distribution}

Type locality: Îles Glorieuses (Inchim Ouan, $11^{\circ} 34^{\prime} \mathrm{S}, 47^{\circ} 19^{\prime} \mathrm{E}$ ), from $20 \mathrm{~m}$. Also known from Kenya, Western Australia, and Loyalty Islands.

Palaemonella dolichodactylus Bruce, 1991

Palaemonella dolichodactylus Bruce 1991b, p 232, Figures 6f-1, 7; Bruce 1991a, p 301; Li 2000, p 101, Figure 110.

\section{Material examined}

Fiji: SUVA 2, Viti Levu, (i) Northeast Lagoon, stn BS $20,18^{\circ} 10.2^{\prime} \mathrm{S}, 178^{\circ} 30.9^{\prime} \mathrm{E}, 14 \mathrm{~m}$, 15 October 1998, 1 ovig. ㅇ (MNHN-Na 15481); (ii) South Lagoon, stn BS 35, $18^{\circ} 08.1^{\prime} \mathrm{S}$, $178^{\circ} 25.3^{\prime} \mathrm{E}, 16 \mathrm{~m}$, coll. B. Richer de Forges, 18 October 1998, 1 ovig. o (MNHN-Na 15480); (iii) West Lagoon, stn CP $66,17^{\circ} 45.1^{\prime} \mathrm{S}, 177^{\circ} 13.7^{\prime} \mathrm{E}, 37 \mathrm{~m}$, coll. B. Richer de Forges, 21 October 1998, 1 ovig. ㅇ (MNHN-Na 15479).

\section{Remarks}

The specimens with the dactyl of ambulatory pereiopods about 12 times longer than proximal deep, propod obscurely segmented, but all of them with the posteroventral angle of fifth abdominal somite armed with acute tooth. Not previously recorded from Fiji. See also remarks on Palaemonella komaii sp. nov.

\section{Distribution}

Type locality: Lagoon Est, New Caledonia, 65-70 m. Also known from the Norfolk Ridge, $250 \mathrm{~m}$ (Bruce 1991b) and Fiji. 
Palaemonella hachijo Okuno, 1999

Palaemonella hachijo Okuno 1999, p 739, Figures 1-3; Okuno 2000, p 1297, Figure 1.

\section{Material examined}

New Caledonia: west coast, mangrove, coll. B. Richer de Forges, 2 December 1992, 1 spm (MNHN-Na 15628).

\section{Remarks}

See also remarks on Palaemonella komaii sp. nov. The specimen is not in good condition, dried, the right second and fifth pereiopods, left fourth and fifth pereiopods lost, left second and third pereiopods detached. But, the long and large antennal spine which is larger than hepatic spine and distinctly exceeds the antennal basicerite, relatively shorter ambulatory dactyl which is about eight times proximal depth and with only one row of dorsal setae, the propod is not segmented and the distoventral spine is relatively longer which is about onethird of dactyl, show that the specimen is closer to $P$. hachijo than to $P$. dolichodactylus. The rostral formula is $2+6 / 3$, similar to the specimens of Okuno (2000), the posteroventral angle of fifth abdominal somite armed with acute tooth. Previously known only from its type locality Hachijo-jima Island, and Okinawa, Japan.

\section{Distribution}

Type locality: Hachijo-jima Island, Japan, 15-45 m. Now also known from New Caledonia, mangrove.

\section{Palaemonella komaii sp. nov.}

(Figures 9-11)

\section{Material examined}

Tonga: BORDAU 2, Vava'u group, stn DW 1583, 327-360 m, $18^{\circ} 37^{\prime} \mathrm{S}, 174^{\circ} 03^{\prime} \mathrm{W}, 13$

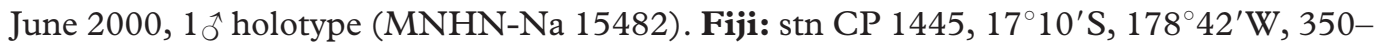

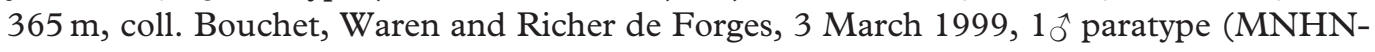
$\mathrm{Na}$ 15600).

\section{Description}

Holotype. A small pontoniine shrimp of subcylindrical body form. Most of pereiopods lost, only detached right first and both fifth pereiopods present.

Carapace smooth, glabrous. Rostrum well developed, shallow, compressed, straight and horizontal, extending beyond anterodorsal margin of second segment of antennular peduncle, about 0.8 of carapace length; dorsal margin with seven (excluding epigastric spine) acute teeth distributed along whole length, interdental spaces smaller anteriorly, first tooth situated slightly posterior to posterior orbital margin; lateral carinae indistinct; ventral margin with two small acute teeth on distal third, smaller than dorsal teeth; interdental spaces and proximal ventral carina feebly setose. Supraorbital spine absent; epigastric spine similar to dorsal rostral teeth, situated at anterior 0.3 of the carapace length; orbit feebly developed, inferior orbital angle feebly produced, bluntly round in lateral view, postorbital carina distinct; antennal spine large slender marginal, distinct below the inferior orbital angle, far exceeding inferior orbital angle, reaching to distal margin of antennal basicerite; hepatic spine distinctly smaller than antennal spine, slender, situated far below level of 


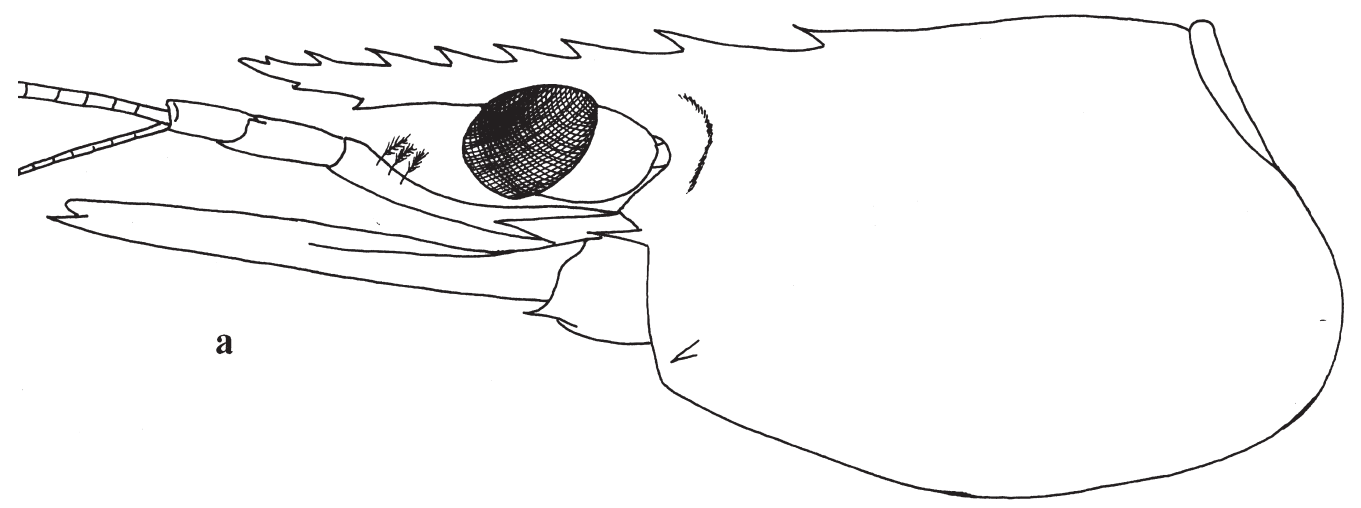

b

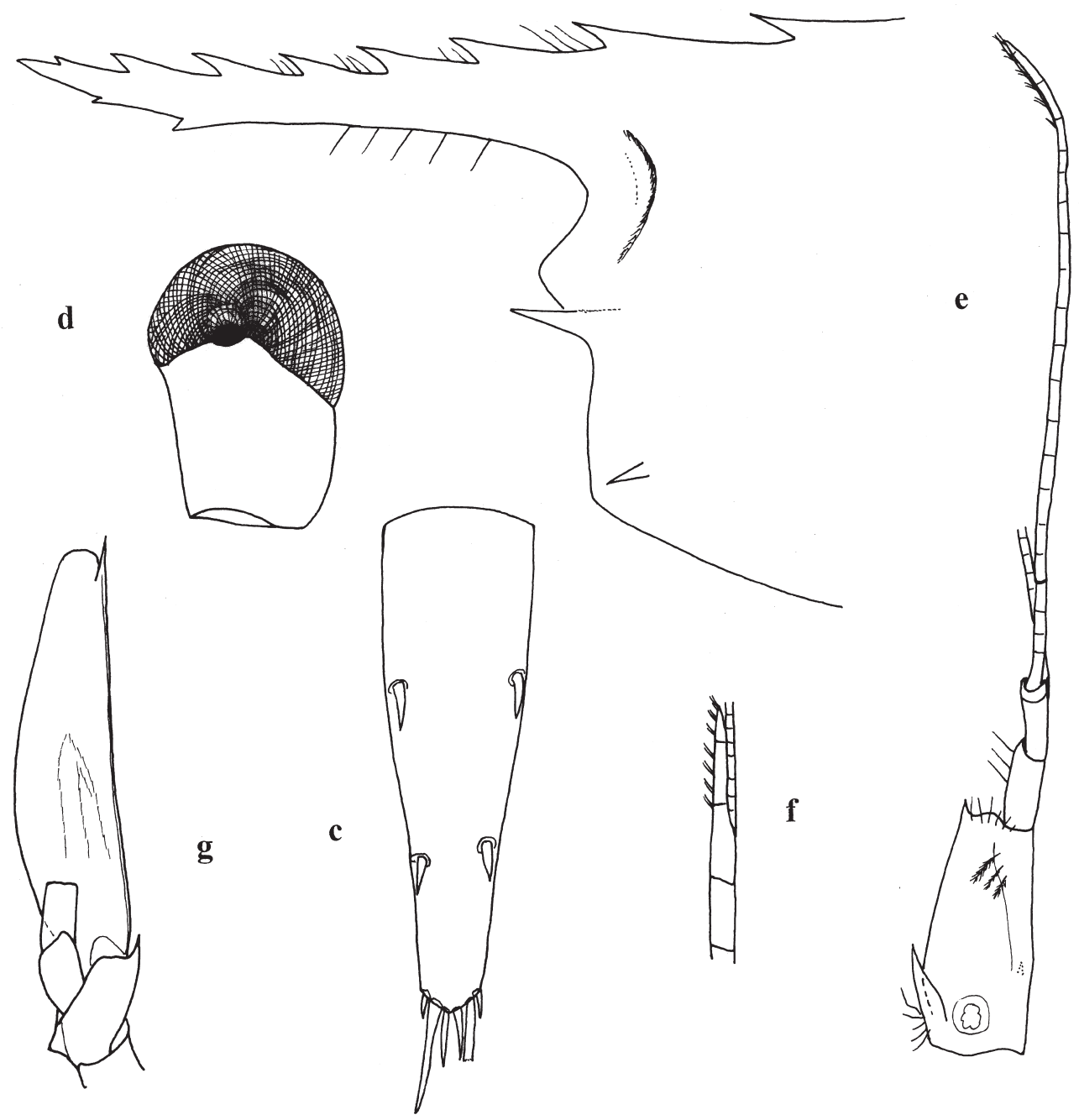

Figure 9. Palaemonella komaii, new species, holotype male (MNHN-Na 15482). (a) Carapace and anterior appendages; (b) anterior carapace; (c) telson; (d) eye, dorsal view; (e) antennule; (f) same, distal shorter free ramus of upper flagellum; (g) antenna. 


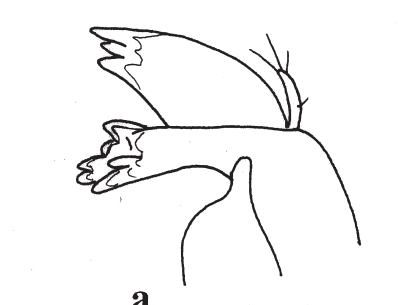

a

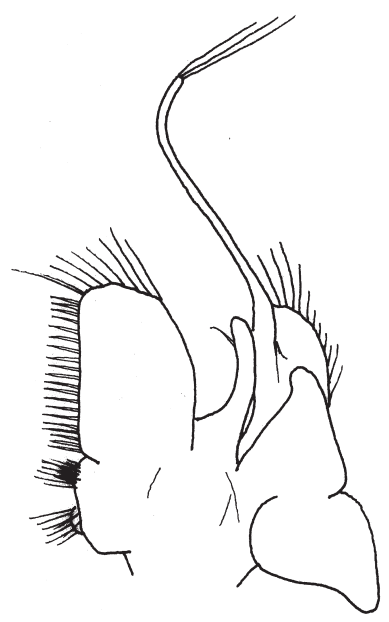

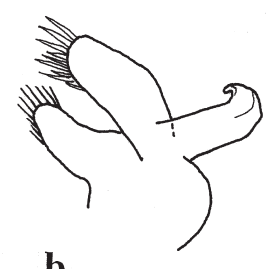

b

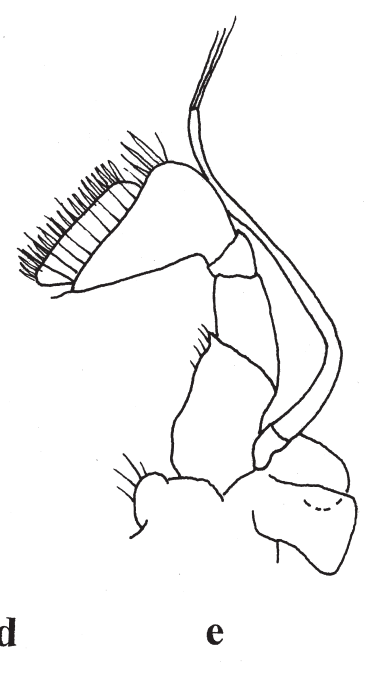

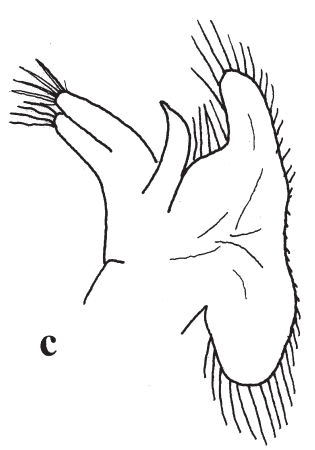

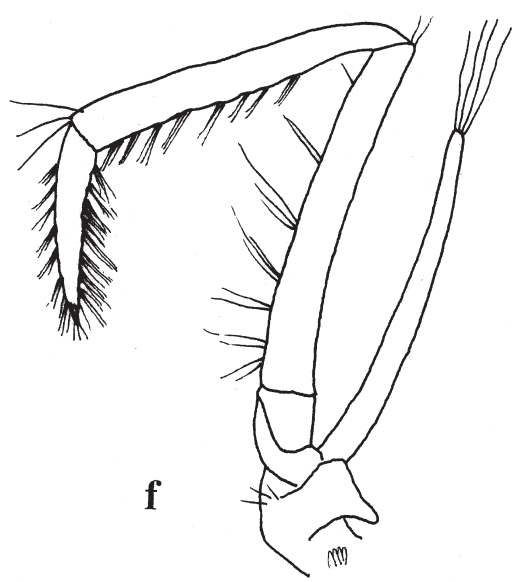

Figure 10. Palaemonella komaii, new species, holotype male (MNHN-Na 15482). (a) Mandible; (b) maxillula; (c) maxilla; (d) first maxilliped; (e) second maxilliped; (f) third maxilliped.

antennal spine and near to anterolateral angle of carapace, below first dorsal rostral tooth in lateral view; anterolateral angle of carapace not produced, bluntly rounded.

Abdominal segments smooth, glabrous; sixth segment about 1.85 times length of fifth, subcylindrical, about 1.80 times longer than deep, subuniform, posterolateral angle acute, posteroventral angle with small acute tooth; pleura of first three segments broadly rounded, fourth and fifth posteriorly produced, fourth with posteroventral angle rounded, fifth with posteroventral angle with acute tooth. Telson about 1.19 times sixth abdominal segment length, about 3.4 times longer than anterior width, lateral margins curved ventrally, convergent, posterior margin about 0.4 of anterior margin width, rounded; dorsal surface with two pairs of developed acute dorsolateral spines at 0.33 and 0.67 of telson length, the spines 0.085 of telson length; three pairs of posterior spines, lateral spines short, similar to dorsal spines, about 0.05 of telson length, intermediate spines long, robust, about 0.22 of telson length, submedian spines slender, about 0.5 of intermediate spine length.

Eye well developed, cornea and stalk distinct compressed, width of cornea 0.28 of postorbital carapace length, accessory pigment spot distinct, fused with cornea; stalk thinner than cornea, length 0.9 of corneal width, 1.16 of its width.

Antennular peduncle slender, exceeding rostrum; proximal segment about 2.24 times longer than width, with slender acute stylocerite laterally, reaching to about 0.42 of segment length, anterolateral margin feebly produced, with well-developed slender acute lateral tooth; 


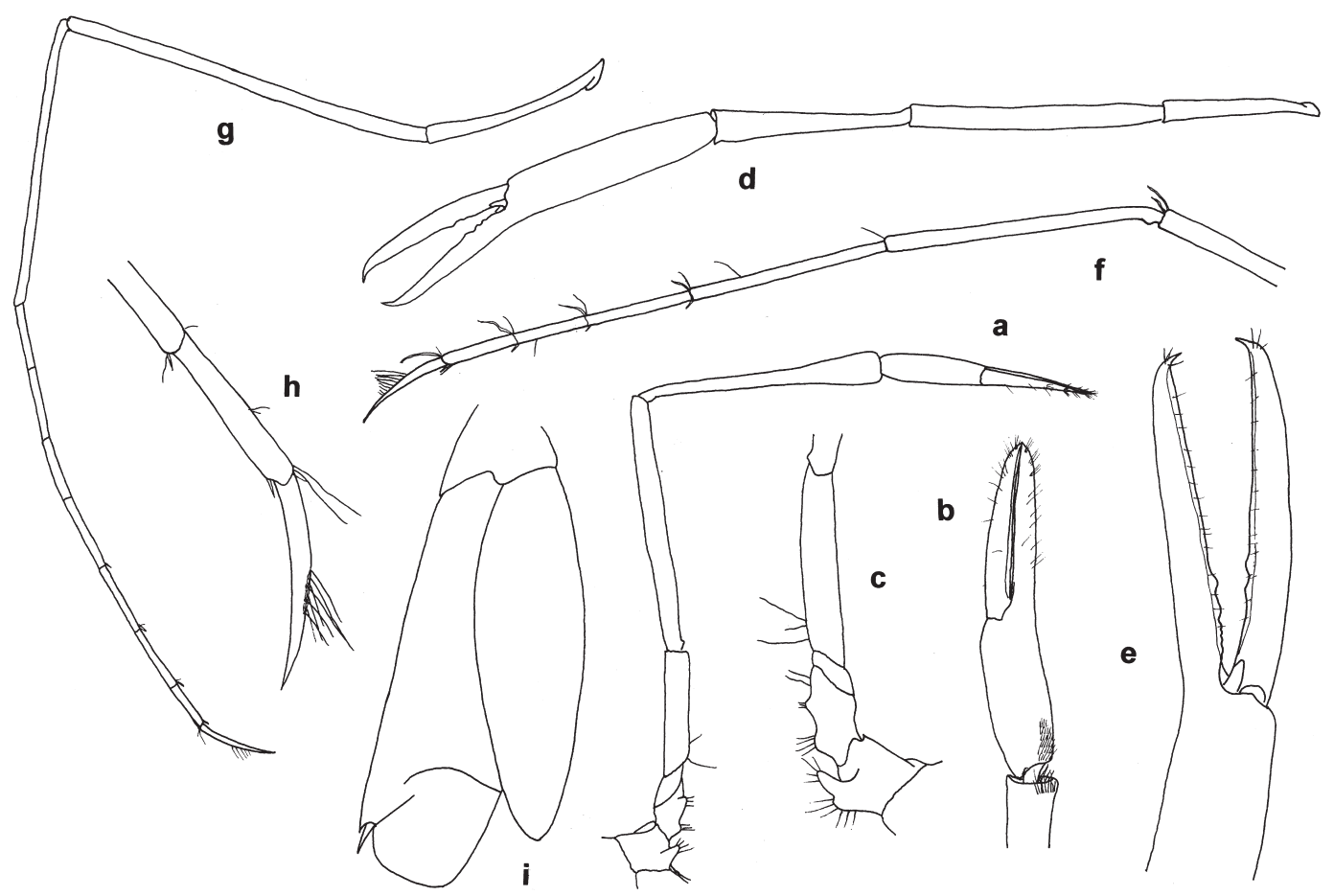

Figure 11. Palaemonella komaii, new species. (a-c, g-i) Holotype male (MNHN-Na 15482); (d-f) paratype male (MNHN-Na 15600). (a) First pereipod; (b) same, chela; (c) same, coxa, basis and ishium; (d) second pereiopod, right; (e) same, chela; (f) third pereiopod, left; (g) fifth pereiopod, left; (h) same, distal propodal subsegment and dactyl; (i) uropod.

statocyst small; medial margin setose, with ventromedial tooth at about 0.5 of length; intermediate segment obliquely articulated with distal segment dorsal length about 0.3 of proximal segment length, 2.1 of width; distal segment subequal to intermediate segment, slender, about 2.6 times longer than distal width; upper flagellum biramous, with 18 proximal segments of rami fused, shorter free ramus with three segments, with about seven groups of aesthetascs; longer ramus, slender, filiform; lower flagellum slender, filiform.

Antennal basicerite robust, with acute distolateral tooth; carpocerite about 0.29 of scaphocerite length, about 3.2 times longer than width, subcylindrical; flagellum lost; scaphocerite well developed, distinctly exceeding antennular peduncle, slender, about 4.0 times longer than wide, greatest width at about 0.4 of length, distal margin bluntly rounded, lateral margin feebly concave, with strong acute distolateral tooth, overreaching distal lamella.

Epistome with median carina. Fourth thoracic sternite with slender finger-like median process, fifth with well-developed posterior transverse ridge separated by deep median notch, with pair of large acute spines on ridge adjacent to notch; sixth and seventh sternites narrow and unarmed; eighth armed with short stout anteriorly directed median process.

Mouthparts typical of the genus. Mandible with corpus moderately robust, with developed palp with three distal setae and one lateral seta; molar process normal, with four strong blunt teeth, lower inner tooth bilobed; incisor process robust, distally with three (right) or four (left) stout acute teeth, central tooth smaller than outer teeth. Maxillula with feebly bilobed palp, upper lobe tapering tip acute, recurved; upper lacinia robust, distal margin feebly rounded with two rows of acute spines; lower lacinia robust, distally rounded, 
with simple setae. Maxilla with short simple non-setose palp, tip acute; basal endite deeply bilobed, upper lobe stouter than lower, with simple setae distally; coxal endite obsolete; scaphognathite well developed, about 3.3 times longer than central width. First maxilliped with simple seta on palp subapically; caridean lobe well developed, with simple setae laterally, exopod with well-developed flagellum, with three long distal plumose setae; basal endite with medial margin with dense simple short setae, coxal endite with medial margin with numerous spines; epipod large, triangular, feebly bilobed. Second maxilliped with normal endopod, dactylar segment about 3.96 times longer than broad, with numerous serrulate spines medially; propodal segment broad, subtriangular, with distal margin with numerous long slender setae; carpus and ischiomerus without special features; basis with distomedial angle acute, with several short setae; coxa feebly produced medially, with four to five simple setae; exopod with slender flagellum with three simple setae distally; epipod oval, with rectangular bilobed podobrach. Third maxilliped with robust endopod, extending distally to end of the carpocerite, ischiomerus and basis fused incompletely, combined segment length about 8.3 times central width, setose medially; intermediate segment about 0.77 of combined proximal segment length, 6.8 times longer than distal width, with eight groups of slender setae medially; terminal segment about 0.44 of combined proximal segment length, distally tapering, about 5.1 times longer than proximal width, with eight dense groups of setae medially and laterally and distal setae; exopod with robust flagellum reaching to 0.83 of combined segment, with four simple plumose setae distally; coxa feebly produced medially, with lobed lateral plate; arthrobranch distinct.

First pereiopods slender, exceeding tip of rostrum by length of chela and distal 0.8 carpus; chela slender, with palm feebly compressed, about 2.7 times longer than maximal depth, at about proximal 0.27 of length with five transverse rows of short cleaning setae proximoventrally; fingers 1.1 times palm length, slender, tapering, cutting edges sharp, entire, tips hooked, with several groups of setae laterally; carpus slender, distally feebly swollen, about 1.13 of chela length, 7.8 times longer than distal width, with row of ventral serrulate cleaning setae subdistally; merus subuniform, about 1.2 times chela length, 11.8 times longer than central width, ventral surface plain, with distinct distoventral groove; ischium 0.63 times length of chela, 6.1 times longer than distal, subuniform, with several long setae proximoventrally; basis with ventral margin sinuous, with two short blunt processes, proximal process setose; coxa with well-developed ventromedial process, setose and lobed.

Ambulatory pereiopods long, slender. Fifth pereiopod exceeds carpocerite by dactyl, propod and carpus, exceeds scaphocerite by dactyl and propod; dactyl long and slender, simple, feebly curved, about 0.17 of propod length, 10.6 times proximal depth, external margin with six long simple setae from 0.4 to 0.7 of dactyl length, outer side with lateral sensory seta at 0.74 of dactyl length; propod uniform, about 1.22 of carapace length, 41.4 times longer than distal width, subdivided into six segments, with pair of short slender simple distoventral spines, three single spines distributed respectively at distoventral margin of third to fifth subsegments, two long setae on distodorsal margin of propod; carpus slender, uniform, about 0.6 of propod length, 21.15 times longer than distal width, unarmed; merus 0.8 of propod length, 27.9 times longer than wide, uniform, unarmed; ischium 0.4 of propod length, 11.9 times longer than distal width, uniform; basis and coxa without special features.

Uropod distinctly exceeding telson; protopodite with posterolateral angle acute; exopod 3.0 times longer than central width, lateral border near straight, with small acute distal tooth and long and acute mobile spine medially, diaeresis distinct; endopod about 0.88 of exopod length, 3.3 times longer than wide. 
Paratype. Right second and left fifth pereiopods detached.

Similar to holotype. Rostrum dorsal margin with five acute teeth (except epigastric spine). First pereiopods exceeding tip of rostrum by length of chela and distal two-thirds of carpus. Second pereiopods similar and equal, very slender and elongate, exceeding tip of rostrum by length of chela, carpus and distal two-thirds of merus; chela 1.7 times carapace length, palm subcylindrical, subuniform, smooth, distinctly curved at fingers articulate, 4.3 times longer than central depth, fingers smooth, 0.8 of palm length, with hooked tips, dactyl 7.2 times longer than proximal depth, cutting edge entire with two small teeth at proximal 0.25 and 0.35 length, distal tooth larger than proximal tooth, distal 0.6 cutting edge entire, fixed finger similar to dactyl, cutting edge with five to six small teeth on proximal 0.34 length, distal two teeth larger than proximal teeth, distal three-quarters cutting edge entire; carpus unarmed, distally swollen, 0.9 of palm length, 6.2 times longer than distal width; merus uniform, unarmed, 1.18 of palm length, subuniform, 10.7 times longer than width; ischium unarmed, slightly dorsoventrally compressed, slightly proximally tapered, about 0.71 of palm length, 9.1 times longer than distal width; basis and coxa normal. Third pereiopod exceeds scaphocerite tip by propod and dactyl; dactyl long and slender, simple, feebly curved, 0.21 of propod length, 8.0 times proximal depth, external margin with eight long simple setae from 0.4 to 0.75 of dactyl length; propod uniform, 0.97 of carapace length, 34.4 times longer than width, subdivided into four (left) or five (right) segments, with pair of short slender simple distoventral spines, three single spines distributed respectively at distoventral margin of third to fifth subsegments, two long setae on distodorsal margin of propod and two long setae on distodorsal margin of subsegments; carpus slender, uniform, 0.6 of propod length, 16.6 times longer than distal width, unarmed; merus, slender, uniform, subequal to propod, 23.4 times longer than wide, unarmed; ischium 0.44 of propod length, 10.1 times longer than distal width, uniform; basis and coxa without special features. Fourth and fifth pereiopods similar to third, fourth exceeds scaphocerite tip by dactyl and distal three-fifths of propod, propod divided into five (left) or four (right) subsegments; fifth pereiopod longer than fourth, exceeds scaphocerite tip by propod and dactyl, propod divided into five subsegments.

\section{Measurements (mm)}

Holotype. Carapace length, 3.39; carapace and rostrum, 6.06; total body length (proximally), 16.8; first pereiopod, chela, 1.95; third pereiopod, propod, 4.14.

Paratype. Carapace length, 3.62; carapace and rostrum, 6.22; first pereiopod, chela, 1.92; second pereiopod, chela, 6.04, third pereiopod, propod, 3.51 .

\section{Systematic position}

Palaemonella komaii sp. nov. is very close to P. dolichodactylus Bruce, 1991 and P. hachijo Okuno, 1999, sharing the features of very long and slender ambulatory pereiopods with the dactyl more than 8.0 times longer than basal depth and with several long setae on dorsal dactyl margin, propod more than 26 times longer than width. The new species can be easily distinguished from $P$. hachijo by the subsegmented and more slender and longer ambulatory propod, and the position of hepatic spine on the carapace which is lower and more anterior, close to the anteroventral angle of the carapace. It differs from $P$. dolichodactylus in the position of the hepatic spine on the carapace which is lower and more anterior, close to the anteroventral angle of the carapace, the longer antennal spine, which 
is longer than the hepatic spine and extends to the anterior margin of the basicerite, the ambulatory propod is more slender and longer (41.4 to 26 times longer than distal width).

\section{Etymology}

The specific name is given in honour of the Japanese carcinologist, Dr Tomoyuki Komai.

\section{Remarks}

The extremely long and slender ambulatory pereiopods with the dactyl more than eight times longer than its depth and with several long setae on dorsal dactyl margin, the propod more than 26 times longer than wide separate the new species and its allied species, P. dolichodactylus Bruce, 1991 and P. hachijo Okuno, 1999, from the other species of the genus Palaemonella. They may form a " $P$. dolichodactylus species complex". The new species looks like an intermediate form between $P$. dolichodactylus and $P$. hachijo, in the features of antennal spine and segmented ambulatory propod. But the ambulatory pereiopod varies with increasing habitat depth: shortest and most robust in $P$. hachijo (shallow waters, $0-45 \mathrm{~m}$ ); moderately long and slender in $P$. dolichodactylus (shallow to deep waters, 16-250 m); longest and most slender in P. komaii (deep water, 327-360 m). The posteroventral angle of the fifth abdominal somite is not a stable character to distinguish $P$. dolichodactylus and P. hachijo, as used by Okuno (1999) and Bruce (2002b), because all specimens of $P$. dolichodactylus we have checked (including the two specimens of Bruce 1991a) have acute tooth on the posteroventral angle of fifth abdominal pleuron.

Palaemonella pottsi (Borradaile, 1915)

Periclimenes (Falciger) pottsi Borradaile 1915, p 212.

Palaemonella pottsi: Kemp 1922, p 126-127; Chace and Bruce 1993, p 89; Li 2000, p 103, Figure 113; Davie 2002, p 316; Li and Liu 2003, p 159, Figure 5a, b; Li 2004a, p 68.

\section{Material examined}

Philippines: (i) MUSORSTOM II, shore station, stn 11, opposite Mactan Marine Station, scuba, 5-18 m, 9 December 1980, 1)ิ (MNHN-Na 15954); (ii) Dumaran Channel, NE Palawan Islands, 2-3 m, coll. P. Bouchet, May 1985, 60ิ ô, 8ợ (6 ovig.)

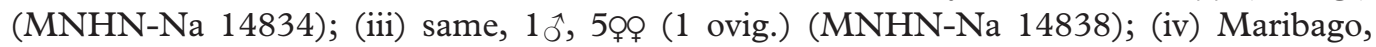
$10^{\circ} 17^{\prime} \mathrm{N}, 124^{\circ} 00^{\prime} \mathrm{E}$, Mactan Island, Cebu Prov., 3-5 m, coll. P. Bouchet, 9 June 1985,

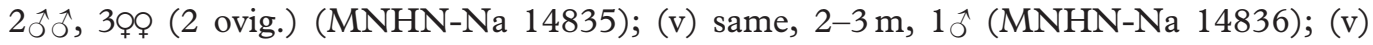
same, $1 \hat{\jmath}, 2$ juveniles (MNHN-Na 14837). New Caledonia: (vi) Touho Bank, 28 August

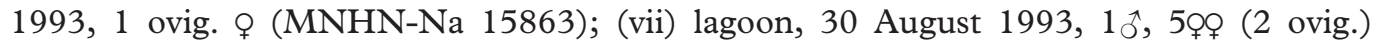
(MNHN-Na 15889). Loyalty Islands: ATELIER LIFOU, Lifou, Santal Bay (viii) Gaatcha Bay, stn $1436,20^{\circ} 55.5^{\prime} \mathrm{S}, 167^{\circ} 04.2^{\prime} \mathrm{E}, 10-20 \mathrm{~m}$, coral head, 10 November 2000 ,

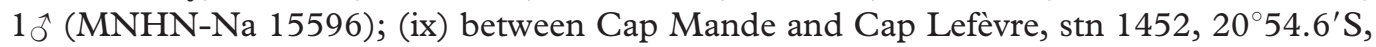
$167^{\circ} 02.1^{\prime} \mathrm{E}, 2-25 \mathrm{~m}$, scuba, 20 and 22 November 2000, 1 ovig. (MNHN-Na 15483).

\section{Hosts}

(i) (ii) (v) Comanthina schlegeli (P. H. Carpenter, 1881); (iv) Comatella ? stelligera (P. H. Carpenter, 1888); (iii) washings from Comatella nigra (P. H. Carpenter, 1888), Comanthus bennetti (J. Müller, 1841), Comaster multibrachiatus (P. H. Carpenter, 1888). Identified by A. M. Clark. (vi) (vii) crinoids. 

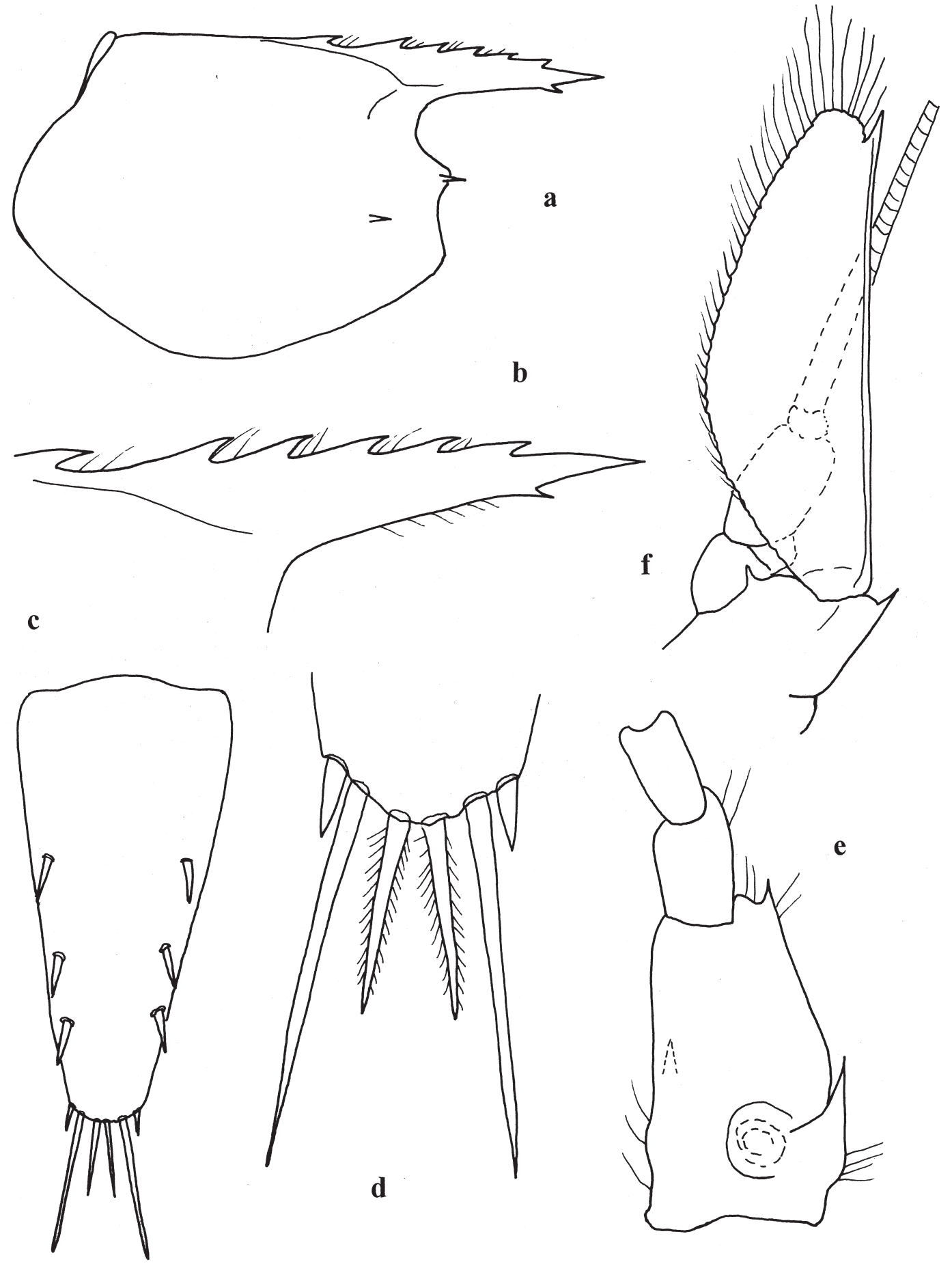

Figure 12. Palaemonella pusilla Bruce, 1975, male (MNHN-Na 14839). (a) Carapace; (b) rostrum; (c) telson; (d) same, distal; (e) antennule; (f) antenna. 


\section{Remarks}

Previously reported from Moalboal Island, Philippines (Bruce 1989a; Markham 1989), and from Nouméa, New Caledonia (Bruce 1970c). Not previously recorded from Loyalty Islands. A well-known associate of the crinoid Comanthina schlegeli.

\section{Distribution}

Type locality: Mabuaig and Murray Islands, Torres Strait. Also known from Zanzibar, Singapore, Japan, Philippines, Indonesia, Australia (Western Australia, Northern Territory, Queensland), New Caledonia, Loyalty Islands, and Marshall Islands.

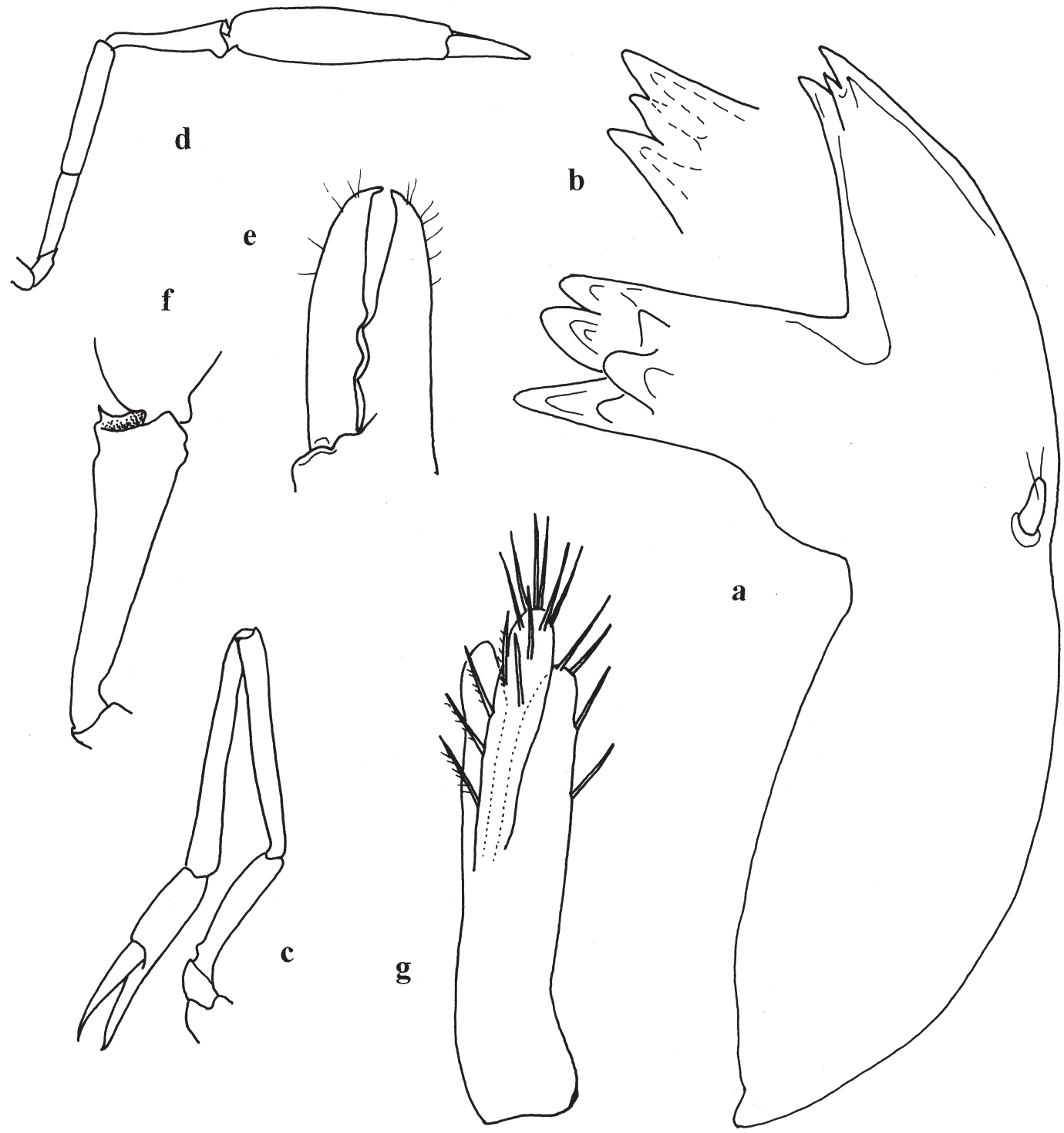

Figure 13. Palaemonella pusilla Bruce, 1975, male (MNHN-Na 14839). (a) Mandible; (b) same, incisor process; (c) first pereiopod; (d) second pereiopod; (e) same, fingers; (f) same, carpus; (g) endopod of second pleopod. 
Palaemonella pusilla Bruce, 1975

(Figures 12, 13)

Palaemonella pusilla Bruce 1975c, p 169-177, Figures 1-5; Li 2000, p 104, Figure 114.

\section{Material examined}

New Caledonia: MONTROUZIER, Koumac, (i) Koumac Pass, outer reef, scuba, 20 m, coll. B. Richer de Forges, 6 October 1993, 1 ऊै (MNHN-Na 14839); (ii) Grand Récif, outer slope, scuba, 12 m, coll. B. Richer de Forges, 7 October 1993, $1 \hat{\jmath}$ (MNHN-Na 14840). Loyalty Islands: ATELIER LIFOU, Lifou, Santal Bay, (iii) Pointe Lefèvre, stn 1435, $20^{\circ} 55.2^{\prime} \mathrm{S}, 167^{\circ} 00.7^{\prime} \mathrm{E}, 5-30 \mathrm{~m}$, steep drop-offs and overhangs, 8 November $2000,2 \widehat{\jmath}^{\widehat{\jmath}}$ (MNHN-Na 15486); (iv) between Huca Hutighé Islet and shore, stn 1421, 20 52.4'S, $167^{\circ} 08.5^{\prime} \mathrm{E}, 4 \mathrm{~m}$, coarse sand on flatstone, 26-27 November 2000, 1 \% (MNHN-Na 15485); (v) west of Easo Point, stn $1451,20^{\circ} 47.3^{\prime} \mathrm{S}, 167^{\circ} 06.8^{\prime} \mathrm{E}, 10-21 \mathrm{~m}$, coral heads, 19 November 2000, 1ð, 3ọ (2 ovig.) (MNHN-Na 15484).

\section{Remarks}

Previously known only from the type material. The specimens are not in good condition but are adequate for identification. The Koumac specimen lacks all second to fifth pereiopods; the Grand Récif specimen has the right second pereiopod still preserved. The rostrum is short and acute, not exceeding the end of the second segment of the antennular peduncle, with a dentition of $1+5 / 1$, without supraorbital ridges or tubercles; antennal spine large, laterally projecting; hepatic spine normal. In the Koumac specimen, the mandible with a small single-segmented palp. Cornea large, about 0.24 of carapace length. Merus of second pereiopod without distoventral spine, carpus distally swollen, with strong dorsal tooth.

\section{Distribution}

Type locality: Kisiti Island, Kenya. Now also known from New Caledonia and Loyalty Islands.

Palaemonella rotumana (Borradaile, 1898)

Periclimenes rotumanus Borradaile 1898, p 383.

Palaemonella vestigialis Kemp 1922, p 123-126, Figures 1, 2, Plate 3, Figure 2.

Palaemonella rotumana: Bruce 1970c, p 276-279, Plate 1e-f; Bruce 1991b, p 229, Figures 5, 6a-e; Chace and Bruce 1993, p 89; Bruce 1996, p 220; Li 2000, p 105, Figure 115; Davie 2002, p 317; Li and Liu 2003, p 160, Figure 5c-q; Li et al. 2004, p 534; Marin et al. 2004, p 203, Figure 4.

\section{Material examined}

New Caledonia: (i) Récif Mbere, $22^{\circ} 19.9^{\prime} \mathrm{S}, 166^{\circ} 13.2^{\prime} \mathrm{E}$, outer slope, $10 \mathrm{~m}$, coll. P. Bouchet, 5 May 1993, 1o (MNHN-Na 15804). MONTROUZIER, (ii) Touho, scuba, $10 \mathrm{~m}$, coll. B. Richer de Forges, 8 September 1993, 1今̄, 2 ovig. 우 (MNHN-Na 14841); (iii) $22^{\circ} 19.35^{\prime} \mathrm{S}, 166^{\circ} 25.85^{\prime} \mathrm{E}, 20 \mathrm{~m}$, scuba, on sponge?, coll. I. Takeuchi, 10 November 1995, 1 ovig. o (MNHN-Na 15910); (iv) $22^{\circ} 56.30^{\prime} \mathrm{S}, 167^{\circ} 20.47^{\prime} \mathrm{E}, 18 \mathrm{~m}$, scuba, on Halimeda, 29 November 1995, 1 juvenile (MNHN-Na 15851); (v) Thio reef flat, Saint Gabriel, 0.8 m, coll. B. Richer de Forges, 19 May 1996, 1 o (MNHN-Na 15856); (vi) Thio 
reef flat, low tide, $1 \mathrm{~m}$, coll. B. Richer de Forges, 1 July 1996, $1 \widehat{\jmath}$ (MNHN-Na 15857); (vii) lagoon, Poingam, low tide, coll. B. Richer de Forges, 10 May 1997, 1 ô, 1 ovig. Q (MNHN$\mathrm{Na}$ 15807). SURPRISES, North New Caledonia, (viii) stn CP 1376, $18^{\circ} 27.2^{\prime} \mathrm{S}$, $163^{\circ} 09.2^{\prime} \mathrm{E}, 39 \mathrm{~m}, 9$ May 1999, coll. Richer de Forges, 1 ovig. o (MNHN-Na 15817);

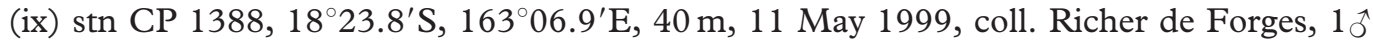
(MNHN-Na 15818). Loyalty Islands: ATELIER LIFOU, Lifou, Santal Bay, (x) Ngoni Beach stn $1459,20^{\circ} 47.0^{\prime} \mathrm{S}, 167^{\circ} 03.0^{\prime} \mathrm{E}, 55-80 \mathrm{~m}$, trawl, 5 and 13 November 2000, $3 \hat{0}^{\hat{0}}$, 3ọ (2 ovig.) (MNHN-Na 15488); (xi) same, 5 November 2000, 1 ऽै (MNHN-Na 15489); (xii) near Huca Hutighé Islet, stn $1434,20^{\circ} 52.5^{\prime} \mathrm{S}, 167^{\circ} 08.1^{\prime} \mathrm{E}, 5-20 \mathrm{~m}$, hard bottom, 6

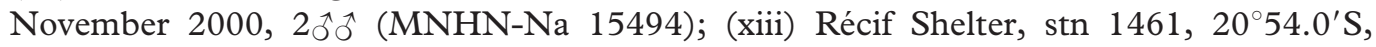
$167^{\circ} 02.1^{\prime} \mathrm{E}, 100-120 \mathrm{~m}$, trawl, 7, 19, and 23 November 2000, 2 ovig. o̊ (MNHN-Na 15491); (xiv) ridge SE of Pointe Aimé Martin (=Acadro), stn 1462, 20 47.1'S, $167^{\circ} 02.1^{\prime} \mathrm{E}, 70-120 \mathrm{~m}$, trawl, 9 and 21 November 2000, 1 ( (MNHN-Na 15487); (xv) east of Santal Bay: Mepinyo, stn $1446,20^{\circ} 50.8^{\prime} \mathrm{S}, 167^{\circ} 09.7^{\prime} \mathrm{E}, 36-40 \mathrm{~m}$, bottom of slope, 16 November 2000, 1ิึ, 1o, 3 juveniles (MNHN-Na 15498); (xvi) north of Cap Aimé Martin (=Acadro), stn $1449,20^{\circ} 45.8^{\prime} \mathrm{S}, 167^{\circ} 01.65^{\prime} \mathrm{E}, 17 \mathrm{~m}$, brushing, 17 November 2000, 2ọ (1 ovig.) (MNHN-Na 15502); (xvii) west of Easo Point, stn 1451, 20 47.3'S, $167^{\circ} 06.8^{\prime} \mathrm{E}, 10-21 \mathrm{~m}$, coral heads, 19 November 2000, $2 \widehat{\jmath}^{\widehat{\jmath}}$ (MNHN-Na 15495); (xviii) east of Easo Point, stn $1418,20^{\circ} 46.9^{\prime} \mathrm{S}, 167^{\circ} 07.9^{\prime} \mathrm{E}, 1-5 \mathrm{~m}$, sand and sea grasses around yacht wharf, 21 November 2000, 1 ovig. $Q$ (MNHN-Na 15500); (xix) between Cap Mande

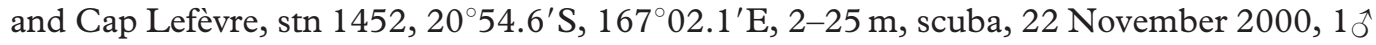
(MNHN-Na 15501); (xx) south of Cap Lefèvre (=Nem), stn 1454, 20 ${ }^{\circ} 56.65^{\prime} \mathrm{S}$,

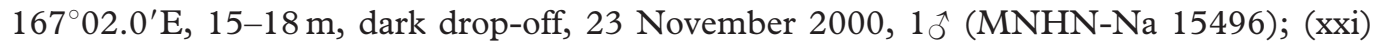
west to southwest Easo Point, stn 1429 , 20 $47.5^{\prime} \mathrm{S}, 167^{\circ} 07.1^{\prime} \mathrm{E}, 8-18 \mathrm{~m}$, coral heads, sedimentary channels, 24 November 2000, 2 ovig. ơ (MNHN-Na 15592); (xxii) between Cap Wekutr and Cap Wajez, stn $1455,20^{\circ} 56.8^{\prime} \mathrm{S}, 167^{\circ} 02.7^{\prime} \mathrm{E}$, slope, $15-20 \mathrm{~m}, 25$ November 2000, 2 ovig. o̊ (MNHN-Na 15492); (xxiii) between Cap Wekutr and Cap

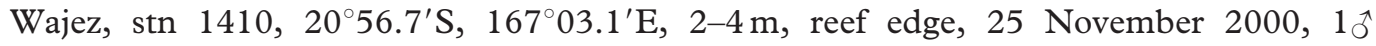
(MNHN-Na 15497); (xxiv) NE of Bay, near Cila, stn 1456, $20^{\circ} 49.3^{\prime} \mathrm{S}, 167^{\circ} 10.4^{\prime} \mathrm{E}$, slope, 25-30 m, 26 November 2000, 60ิ ô, 1 ọ (MNHN-Na 15490); (xxv) between Huca Hutighé Islet and shore, stn $1421,20^{\circ} 52.4^{\prime} \mathrm{S}, 167^{\circ} 08.5^{\prime} \mathrm{E}, 4 \mathrm{~m}$, coarse sand on flatstone, 26-27 November 2000, 1 ovig. o (MNHN-Na 15499); (xxvi) near Ngoni, stn 1457, 20 46.8'S, $167^{\circ} 02.75^{\prime} \mathrm{E}, 5-10 \mathrm{~m}$, dark overhang and boulder, 27 November 2000, $1 \hat{0}, 1$ ovig. (MNHN-Na 15493). Chateaubriand Bay, (xxvii) Wé Beach, stn 1474, 20 54.8'S, $167^{\circ} 16.1^{\prime} \mathrm{E}, 0-3 \mathrm{~m}$, fine sand and Porites heads, 11 November 2000, 3 ovig. 우 (MNHN-Na 15503).

\section{Remarks}

Mandible of male with small two-segmented palp. Specimens with most of second to fifth pereiopods missing. Previously reported from New Caledonia, from Nouméa (Bruce 1970c, 1991b). Not previously recorded from Loyalty Islands.

\section{Distribution}

Type locality: Rotuma Island, Fiji. Widely distributed from the northern Red Sea to Mozambique, including Australia (Western Australia, Northern Territory, Queensland) and east to Fiji and Hawaii, north to Japan, south to New Caledonia, also found in the Eastern Mediterranean Sea. 
Palaemonella spinulata Yokoya, 1936

Palaemonella spinulata Yokoya 1936, p 135, Figure 4; Li 2000, p 106, Figure 116; Davie 2002, p 317.

\section{Material examined}

New Caledonia: (i) MONTROUZIER, Touho, sandy island, scuba, coll. B. Richer de Forges, 7 September 1993, 1 ovig. ㅇ (MNHN-Na 14842). Loyalty Islands: ATELIER LIFOU, Lifou, Santal Bay, (ii) west-southwest of Easo Point, stn 1429, 20 47.5'S, $167^{\circ} 07.1^{\prime} \mathrm{E}, 8-18 \mathrm{~m}$, coral heads, sedimentary channels, 5 November 2000,1 ovig. O? (MNHN-Na 15510); (iii) in front of Ngoni beach, stn $1459,20^{\circ} 47.0^{\prime} \mathrm{S}, 167^{\circ} 03.0^{\prime} \mathrm{E}, 55-$ $80 \mathrm{~m}$, trawl, 5 and 13 November 2000, $1 \widehat{O}^{\hat{\theta}}$ (MNHN-Na 15506); (iv) north of Cap Aimé Martin (=Acadro), stn $1449,20^{\circ} 45.8^{\prime} \mathrm{S}, 167^{\circ} 01.65^{\prime} \mathrm{E}, 17 \mathrm{~m}$, washing, 17 November 2000 ,

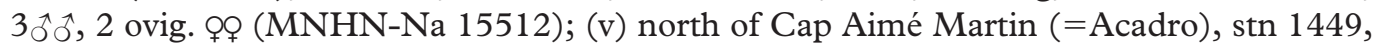
$20^{\circ} 45.8^{\prime} \mathrm{S}, 167^{\circ} 01.65^{\prime} \mathrm{E}, 17 \mathrm{~m}, 17$ November 2000, 1 ovig. ㅇ (MNHN-Na 15594); (vi) Chépénéhé Point, stn $1420,20^{\circ} 47.7^{\prime} \mathrm{S}, 167^{\circ} 09.35^{\prime} \mathrm{E}, 4-5 \mathrm{~m}$, flatstone with sediment cover, 18-19 November 2000, 1 ovig. ㅇ (MNHN-Na 15507); (vii) between Cap Mande and Cap Lefèvre $(=\mathrm{Nem})$, stn $1452,20^{\circ} 54.6^{\prime} \mathrm{S}, 167^{\circ} 02.1^{\prime} \mathrm{E}, 2-25 \mathrm{~m}$, scuba, 20 and 22 November 2000, 3 ovig. ợ (MNHN-Na 15511); (viii) south of Cap Lefèvre (=Nem), stn 1454, $20^{\circ} 56.65^{\prime} \mathrm{S}, 167^{\circ} 02.0^{\prime} \mathrm{E}, 15-18 \mathrm{~m}, 23$ November 2000, 1 ovig. ㅇ (MNHN-Na 15508); (ix) west-southwest of Easo Point, stn $1429,20^{\circ} 47.5^{\prime} \mathrm{S}, 167^{\circ} 07.1^{\prime} \mathrm{E}, 8-18 \mathrm{~m}$, coral heads,

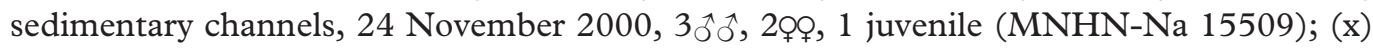
near Ngoni, stn $1457,20^{\circ} 46.8^{\prime} \mathrm{S}, 167^{\circ} 02.75^{\prime} \mathrm{E}, 5-10 \mathrm{~m}, 27$ November 2000, 1 ovig. ㅇ (MNHN-Na 15505); (xi) Kuendu Bay, 0.5 m, coll. B. Richer de Forges, 5 May 1996, $3 \hat{\jmath} \widehat{\jmath}$, 1 ovig. ㅇ (MNHN-Na 15827).

Remarks

Not previously recorded from New Caledonia and Loyalty Islands.

\section{Distribution}

Type locality: Misaki, Japan. Otherwise known from Kenya, Tanzania, La Réunion, Japan and Australia (Northern Territory, Queensland), New Caledonia, and Loyalty Islands.

Paraclimenes franklinae (Bruce, 1990) nom. nov.

Periclimenes franklini Bruce 1990b, p 55, Figures 1-5; Bruce 1991a, p 314, Figure 9; Li 2000, p 182, Figure 230.

Paraclimenes franklini: Bruce 1994, p 99, Figure 45; Li 2004b, p 820, Figures 1, 2.

Paraclimenes cf. franklini: Li et al. 2004, p 534, Figure 20.

Material examined

Tonga: BORDAU 2, (i) “seamount”, N Ha'apai group, stn CP 1575, $19^{\circ} 42^{\prime} \mathrm{S}, 174^{\circ} 21^{\prime} \mathrm{W}$, 232-295 m, 11 June 2000, 1 ovig. @ (MNHN-Na 15516); (ii) same, stn CP 1626, $23^{\circ} 20^{\prime} \mathrm{S}$, $176^{\circ} 14^{\prime} \mathrm{W}, 220-249 \mathrm{~m}, 19$ June 2000,2 ovig. ㅇํ (MNHN-Na 15517). Vanuatu: (iii) MUSORSTOM 8, stn CP1135, $15^{\circ} 40.50^{\prime} \mathrm{S}, 167^{\circ} 02.43^{\prime} \mathrm{W}, 282-375 \mathrm{~m}, 11$ October 1994, 1 ovig. ㅇ (MNHN-Na 15871).

Remarks

Not previously recorded from Tonga. The spelling of the specific name is now corrected according to the ICZN rules. 


\section{Distribution}

Type locality: Coral Sea. Also reported from South China Sea, New Caledonia, and Tonga.

\section{Paranchistus nobilii Holthuis, 1952}

Anchistus Miersi Nobili 1906b, p 48 (non Harpilius Miersi De Man 1888).

Paranchistus nobilii Holthuis 1952a, p 100, Figures 41, 42; Bruce 1983b, p 890, Figures 6E, 8I, J; Li 2000, p 111, Figure 120.

Material examined

New Caledonia: lagoon, Five Mile Chenal, scuba, 15-20 m, coll. C. Vadon, 20 September 1978, 1ิึ, 2 ovig. ơ? (MNHN-Na 15886).

\section{Remarks}

Not previously recorded from New Caledonia.

\section{Distribution}

Type locality: Persian Gulf. Also known from Indonesia, New Caledonia, and Kiribati Islands (Gilbert Islands).

\section{Paranchistus ornatus Holthuis, 1952}

Paranchistus ornatus Holthuis 1952a, p 97-100, Figures 39, 40; Hipeau-Jacquotte 1974, p 403; Bruce 1975b, p 162; Fransen 1994, p 117, Plate 2D; Li 2000, p 111, Figure 121.

Material examined

Madagascar: Toliara (Tuléar), Grand Récif, coll. A. Crosnier, October 1958, 1ठิ (MNHN-Na 14844).

Host

Pinna sp. [Pinnidae, Mollusca].

\section{Remarks}

Well known from Madagascar, where it has been studied in detail by Hipeau-Jacquotte (1974).

\section{Distribution}

Type locality: Mozambique. Also known from Kenya, Zanzibar, Comoro Islands, Madagascar, and Seychelles. 
Periclimenella petitthouarsi (Audouin, 1825)

Palaemon Petitthouarsii Audouin 1825, p 91.

Periclimenes Petitthouarsi: Borradaile 1898, p 381.

Periclimenella petitthouarsii: Duris and Bruce 1995, p 645-655, Figures 13-18; Li 2000, p 143, Figure 177.

Material examined

Madagascar: Ambalatoaka, Nosy Be, coll. A. Crosnier, September 1958, $1 \hat{\jmath}(\mathrm{MNHN}-\mathrm{Na}$ 14846).

Remarks

Previously recorded from Madagascar, at Nosy Be by Bruce (1977c, 1978a). The specimen has a rostral dentition of $1+6 / 4$, and possesses both second pereiopods.

\section{Distribution}

Type locality: Egypt. Also known from Red Sea, Egypt, Israel, Saudi Arabia, Sudan, Eritrea, Yemen, Djibouti, Kenya, Zanzibar, Tanzania, Comoro Islands, Madagascar, and Persian Gulf.

Periclimenella spinifera (De Man, 1902)

Periclimenes Petithouarsi var. spinifera De Man 1902, p 824-826.

Periclimenes (Ancylocaris) spiniferus: Kemp 1922, p 195-196.

Periclimenes (Harpilius) spiniferus: Holthuis 1952a, p 76-78, Figure 30.

Periclimenes spiniferus: Chace and Bruce 1993, p 122.

Periclimenella spinifera: Duris and Bruce 1995, p 656-661, Figures 19, 20; Bruce 1996, p 227; Li 2000, p 144, Figure 178; Davie 2002, p 321; Li and Liu 2003, p 163, Figure 8; Li et al. 2004, p 541.

\section{Material examined}

New Caledonia: (i) MONTROUZIER, Toumo Bay, coll. B. Richer de Forges,

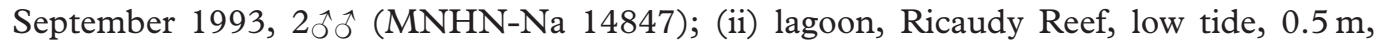
coll. B. Richer de Forges, 30 June 1996, 1 ( (MNHN-Na 15852); (iii) lagoon, Ricaudy reef flat, low tide, coll. B. Richer de Forges, 22 June 1997, 1o (with hemiarthrinid bopyrid), 1 ovig. @ (MNHN-Na 15822). Loyalty Islands: ATELIER LIFOU, Lifou, Santal Bay, (iv) near Huca Hutighé Islet, stn $1434,20^{\circ} 52.5^{\prime} \mathrm{S}, 167^{\circ} 08.1^{\prime} \mathrm{E}, 5-20 \mathrm{~m}$, hard bottom, 6 November 2000, 4ọ (3 ovig.) (MNHN-Na 15518); (v) Easo, near wharf, stn 1406, $20^{\circ} 46.85^{\prime} \mathrm{S}, 167^{\circ} 07.75^{\prime} \mathrm{E}$, intertidal, hard bottom, 10, 13, 14, 16, and 18 November 2000,

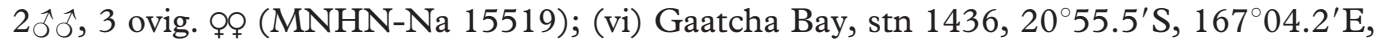

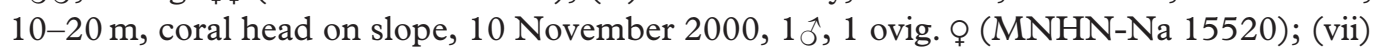
east of Easo Point, stn $1418,20^{\circ} 46.9^{\prime} \mathrm{S}, 167^{\circ} 07.9^{\prime} \mathrm{E}, 1-5 \mathrm{~m}$, sand and sea grasses around yacht wharf, 21 November 2000, 1 ( $(\mathrm{MNHN}-\mathrm{Na} 15521)$. 


\section{Remarks}

Previously reported from New Caledonia, from Senez Reef (Bruce 1996). Not previously recorded from Loyalty Islands.

\section{Distribution}

Type locality: Ternate, Ambon, Indonesia. Also known from Kenya, Tanzania, Madagascar, Seychelles, La Réunion, Maldives, Chagos Islands, Gulf of Mannar, Andaman Islands, Nicobar Islands, Burma, Malaya, Singapore, Vietnam, South China Sea, Japan, Philippines, Indonesia, Papua New Guinea, Australia (Western Australia, Northern Territory, Queensland), Mariannas Islands, New Caledonia, Loyalty Islands, Marshall Islands, Fiji, Samoan Islands, and French Polynesia (Society Islands).

Periclimenes affinis (Zehntner, 1894)

Palaemonella affinis Zehntner 1894, p 208.

Periclimenes (Harpilius) affinis: Holthuis 1958, p 6-8, Figure 2.

Periclimenes affinis: Bruce 1980b, p 2-8, Figures 1-3; Chace and Bruce 1993, p 99; Li 2000, p 149, Figure 180; Davie 2002, p 323; Li and Liu 2004, p 89, Figure 1a-f.

\section{Material examined}

Philippines: (i) Maribago, Mactan Island, Cebu, $10^{\circ} 17^{\prime} \mathrm{N}, 124^{\circ} 00^{\prime} \mathrm{E}, 2-3 \mathrm{~m}$, crinoid washings, coll. P. Bouchet, 9 June 1985, 1) , 10??, 3 juveniles (MNHN-Na 14849); (ii) same, 1o, 2 juveniles (MNHN-Na 14850); (iii) Dumaran Channel, NE Palawan Islands, 2-3 m, crinoid washings, coll. P. Bouchet, May 1985, 3ㅊㅎ, 15фo (9 ovig.), 3 juveniles (MNHN-Na 14848). New Caledonia: (iv) Touho Bank, on crinoids, 28 August 1993,

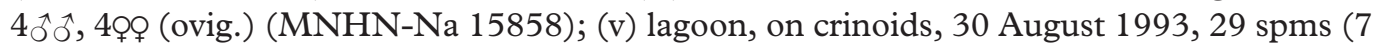
ovig. o̊) (MNHN-Na 15865); (vi) Touho, Kohe, 8 September 1993, $2 \widehat{o}^{\widehat{o}}$ (MNHN-Na 15901).

Hosts

(i) (iii) Comanthina schlegeli (P. H. Carpenter, 1882); (ii) Comatella ?stelligera (P. H. Carpenter, 1880), det. A. M. Clark. (vi) Comatella sp. [Crinoidea, Echinoderma].

Remarks

Previously reported from the Philippines, with 3 ovig. ọ collected in 1908, from Siasi, Sulu Islands (Chace and Bruce 1993).

\section{Distribution}

Type locality: Ambon, Indonesia. Also known from South China Sea, Japan, Philippines, Indonesia, Australia (Northern Territory, Queensland), and New Caledonia. 
Periclimenes alcocki Kemp, 1922

Palaemon (Brachcarpus) laccadivensis Alcock 1901, p 138-139 (partim).

Periclimenes (Periclimenes) alcocki Kemp 1922, p 154-156, Figures 21-24.

Periclimenes alcocki: Bruce 1978a, p 227-228, Figure 10; Bruce 1991a, p 302-308, Figures 2-5; Chace and Bruce 1993, p 102; Bruce 1996, p 228, Figure 11b-d; Li 2000, p 151, Figure 184; Davie 2002, p 323.

\section{Material examined}

Philippines: MUSORSTOM 3, (i) stn CP105, $13^{\circ} 52^{\prime} \mathrm{N}, 120^{\circ} 30^{\prime} \mathrm{E}, 398-417 \mathrm{~m}$, 1 June 1985, 1 ovig. $\bigcirc(\mathrm{MNHN}-\mathrm{Na} 14853)$; (ii) stn $\mathrm{CP} 125,11^{\circ} 57^{\prime} \mathrm{N}, 121^{\circ} 28^{\prime} \mathrm{E}, 388-404 \mathrm{~m}, 4$ June 1985, 1 ovig. @ (MNHN-Na 14851); (iii) same, 1 ovig. @ (MNHN-Na 14852). Indonesia: KARUBAR, Tanimbar Islands, (iv) stn CC21, $5^{\circ} 14^{\prime} \mathrm{S}, 133^{\circ} 00^{\prime} \mathrm{E}, 688-694 \mathrm{~m}$, 25 October 1991, 10َ (MNHN-Na 14860); (v) stn CP59, $8^{\circ} 20^{\prime} \mathrm{S}, 132^{\circ} 11^{\prime} \mathrm{E}, 405-399 \mathrm{~m}$, 31 October 1991, 2 ovig. ọ (MNHN-Na 14856); (vi) stn CP69, 842'S, $131^{\circ} 53^{\prime} \mathrm{E}, 356-$ 368 m, 2 November 1991, 1o (MNHN-Na 14857); (vii) same, 2ọ (MNHN-Na 14858); (viii) stn CP75, $8^{\circ} 46^{\prime} \mathrm{S}, 131^{\circ} 36^{\prime} \mathrm{E}, 451-452 \mathrm{~m}, 3$ November 1991,1 ovig. $\$$ (MNHN-Na 14862); (ix) same, 1 ( (MNHN-Na 14859); (x) stn CP76, $8^{\circ} 50^{\prime \prime} \mathrm{S}, 131^{\circ} 33^{\prime} \mathrm{E}, 401-400 \mathrm{~m}$, 3 November 1991, 2 ovig. ㅇํ (MNHN-Na 14854); (xi) stn CP83, 9²3'S, $131^{\circ} 00^{\prime} \mathrm{E}, 285-$ 292 m, 4 November 1991, 1 ovig. $\&$ (MNHN-Na 14861). New Caledonia: BIOCAL, (xii) stn CP78, $22^{\circ} 16.25^{\prime} \mathrm{S}, 167^{\circ} 15.53^{\prime} \mathrm{E}, 445-450 \mathrm{~m}$, 5 September 1985 , 1 \% (MNHN-Na 14867). MUSORSTOM 4, (xiii) stn $202,18^{\circ} 58.0^{\prime} \mathrm{S}, 169^{\circ} 59.3^{\prime} \mathrm{E}, 560 \mathrm{~m}, 20$ September $1985,1{ }^{\top}$ (MNHN-Na 14864); (xiv) stn $236,22^{\circ} 11.3^{\prime} \mathrm{S}, 167^{\circ} 15.0^{\prime} \mathrm{E}, 495-550 \mathrm{~m}, 2$ October 1985, 10َ (MNHN-Na 14866). MUSORSTOM 5, (xv) stn 384, $19^{\circ} 42.4^{\prime} \mathrm{S}$, $158^{\circ} 50.8^{\prime} \mathrm{E}, 772-756 \mathrm{~m}, 21$ October 1986, 1 ( ) (MNHN-Na 14863). BATHUS 4, (xvi) stn $\mathrm{CP} 911,18^{\circ} 57.80^{\prime} \mathrm{S}, 163^{\circ} 08.47^{\prime} \mathrm{E}, 566-558 \mathrm{~m}, 5$ August $1994,2{ }^{\circ}$ (MNHN-Na 15846); (xvii) stn CP921, $18^{\circ} 46.72^{\prime} \mathrm{S}, 163^{\circ} 17.01^{\prime} \mathrm{E}, 613-610 \mathrm{~m}, 6$ August $1994,1 \widehat{o}^{\wedge}$ (MNHN-Na 15631). NORFOLK 2, (xviii) Île des Pins, stn DW $2147,22^{\circ} 50^{\prime} \mathrm{S}, 167^{\circ} 16^{\prime} \mathrm{W}, 496 \mathrm{~m}, 4$ November 2003, 1ð̄, 6 ovig. OQ (MNHN-Na 15523). Tonga: (xix) BORDAU 2,

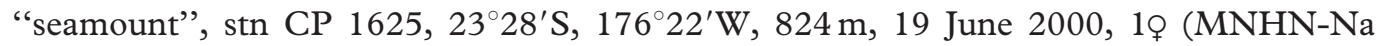
15522). Fiji: BORDAU 1, (xx) stn CP 1446, $17^{\circ} 11^{\prime} \mathrm{S}, 178^{\circ} 42^{\prime} \mathrm{W}, 350-367 \mathrm{~m}$, 3 March 1999, 1 $\jmath^{\jmath}, 1$ ovig. ㅇ (MNHN-Na 15524); (xxi) stn DW 1497, $18^{\circ} 44^{\prime} \mathrm{S}, 178^{\circ} 25^{\prime} \mathrm{W}, 335-$ 350 m, 12 March 1999, 1 ovig. @ (MNHN-Na 15527). Solomon Islands: SALOMON 1, (xxii) stn CP 1804, 9 $32.0^{\prime} \mathrm{S}, 160^{\circ} 37.4^{\prime} \mathrm{E}, 609-328 \mathrm{~m}, 2$ October 2001, 1 ô, 1 ovig. ㅇ (MNHN-Na 15529); (xxiii) stn CP 1860, $9^{\circ} 22^{\prime} \mathrm{S}, 160^{\circ} 31^{\prime} \mathrm{E}, 620 \mathrm{~m}, 7$ October 2001,1 ovig. ㅇ (MNHN-Na 15528).

\section{Remarks}

Previously recorded from Philippines, from $14^{\circ} 00^{\prime} \mathrm{N}, 120^{\circ} 16^{\prime} \mathrm{E}$ (Bruce 1981a), Indonesia, from the Tanimbar Islands (Bruce 1996), and Loyalty Islands and New Caledonia (Bruce 1991a).

\section{Distribution}

Type locality: Laccadive Sea, $9^{\circ} 34^{\prime} 57^{\prime \prime} \mathrm{N}, 70^{\circ} 36^{\prime} 30^{\prime \prime} \mathrm{E}, 930 \mathrm{~m}$ (erroneously given as $90^{\circ} \mathrm{N}$ in Bruce 1996). Also previously reported from Philippines, Indonesia, Australia (New South Wales), and New Caledonia. 
Periclimenes aleator Bruce, 1991

(Figure 14)

Periclimenes aleator Bruce 1991a, p 315-322, Figures 10-14; Li 2000, p 152, Figure 185.

Material examined

Indonesia: KARUBAR, (i) Kai Islands, stn $\mathrm{CP} 16,5^{\circ} 17^{\prime} \mathrm{S}, 132^{\circ} 50^{\prime} \mathrm{E}, 315-349 \mathrm{~m}, 24$ October 1991, 1 ovig. O (MNHN-Na 14869); (ii) Tanimbar Islands, stn CP38, $7^{\circ} 40^{\prime} \mathrm{S}$, $132^{\circ} 27^{\prime} \mathrm{E}, 620-666 \mathrm{~m}, 28$ October 1991, 19 (MNHN-Na 14868). Solomon Islands: (iii) SALOMON 1, stn CP 1786, $9^{\circ} 21.3^{\prime} \mathrm{S}, 160^{\circ} 24.6^{\prime} \mathrm{E}, 387 \mathrm{~m}, 30$ September $2001,1 \delta^{\hat{\gamma}}$ (MNHN-Na 15532). SALOMON 2, (iv) Vella Gulf, stn CP2260, 8 $03.5^{\prime} \mathrm{S}, 156^{\circ} 54.5^{\prime} \mathrm{E}$, 399-427 m, November 2004, 2 ovig. oᄋ (MNHN-Na 15946). Vanuatu: (v) MUSORSTOM 8, stn CP1136, $15^{\circ} 40.62^{\prime} \mathrm{S}, 167^{\circ} 01.60^{\prime} \mathrm{W}, 398-400 \mathrm{~m}, 11$ October 1994, 1 ovig. + (MNHN-Na 15873). New Caledonia: SMIB 8, (vi) stn DW146, $24^{\circ} 55.20^{\prime} \mathrm{S}, 1^{\circ} 8^{\circ} 21.73^{\prime} \mathrm{E}$, Banc Éponge (Mont B), 514-522 m, 27 January 1993, 1 ovig. ㅇ (MNHN-Na 14946). BATHUS 4, (vii) stn DW899, $20^{\circ} 16.68^{\prime} \mathrm{S}, 163^{\circ} 50.26^{\prime} \mathrm{W}, 500$ $600 \mathrm{~m}, 3$ August 1994, 1 ovig. \& (MNHN-Na 15870); (viii) stn DW912, $18^{\circ} 55.61^{\prime} \mathrm{S}$, $163^{\circ} 07.68^{\prime} \mathrm{W}, 702-690 \mathrm{~m}, 5$ August 1994, 1 ( (MNHN-Na 15867); (ix) stn DW923, $18^{\circ} 51.51^{\prime} \mathrm{S}, 163^{\circ} 24.17^{\prime} \mathrm{W}, 502-470 \mathrm{~m}, 6$ August 1994,1 ovig. @ (MNHN-Na 15868). LITHIST, (x) stn CP09, $24^{\circ} 52.8^{\prime} \mathrm{S}, 168^{\circ} 21.8^{\prime} \mathrm{E}, 518-540 \mathrm{~m}$, Banc Éponge, 11 August 1999, 1 ovig. o (MNHN-Na 15891). NORFOLK 2, (xi) Norfolk Ridge, Kaimon Maru Bank, stn DW 2098, 24 $42^{\prime} \mathrm{S}, 168^{\circ} 06^{\prime} \mathrm{W}, 550-668 \mathrm{~m}, 29$ October 2003, 1 ovig. 우 (MNHN-Na 15934); (xii) Norfolk Ridge, Antigonia Bank, stn CP 2122, $23^{\circ} 22^{\prime} \mathrm{S}$, $168^{\circ} 00^{\prime} \mathrm{W}, 560-577 \mathrm{~m}, 1$ November 2003, 1 ovig. $\%$ (MNHN-Na 15935). Loyalty
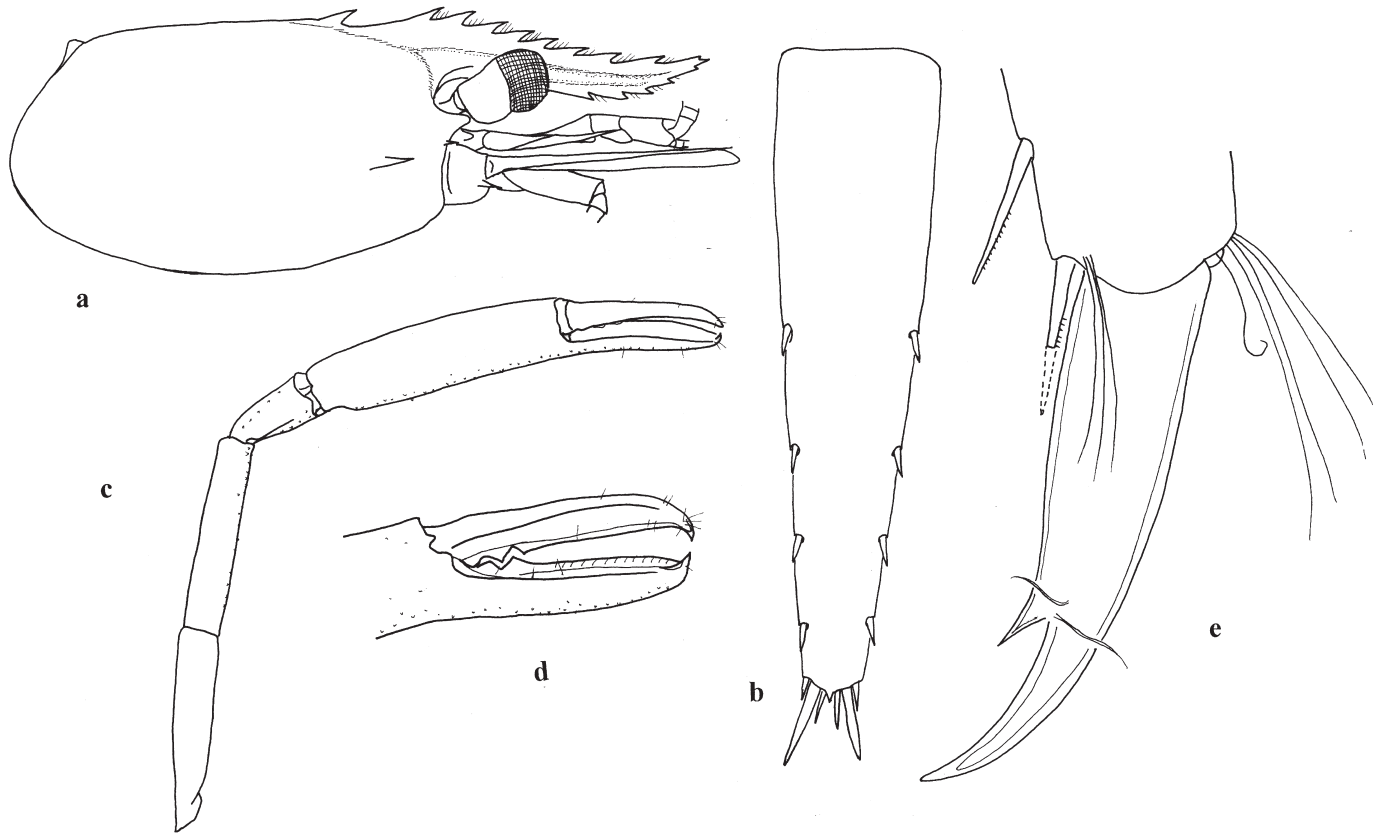

Figure 14. Periclimenes aleator Bruce, 1991, ovigerous female (MNHN-Na 14946). (a) Carapace and anterior appendages; (b) telson; (c) right (major) second pereiopod; (d) same, fingers; (e) third pereiopod, distal propod and dactyl. 
Islands: (xiii) MUSORSTOM 6, stn CP467, 21 $05.13^{\prime} \mathrm{S}, 167^{\circ} 32.11^{\prime} \mathrm{E}, 575 \mathrm{~m}, 21$ February 1989, 1へ(MNHN-Na 14870). Fiji: BORDAU 1, (xiv) stn DW 1499, $18^{\circ} 40^{\prime}$ S, $178^{\circ} 27^{\prime} \mathrm{W}, 389-400 \mathrm{~m}, 12$ March 1999, 1 ovig. ㅇ (MNHN-Na 15525); (xv) stn CP 1504, $18^{\circ} 13^{\prime} \mathrm{S}, 178^{\circ} 34^{\prime} \mathrm{W}, 427-440 \mathrm{~m}, 13$ March 1999, 1 ovig. ㅇ (MNHN-Na 15526).

\section{Parasites}

The Loyalty Islands male (xiii) had a ventral abdominal hemiarthrinid parasite, Paraphrixus nigrocinctus (Chopra) (Isopoda: Bopyridae).

\section{Remarks}

Previously known only from the type material from the Loyalty Islands from 570-610 m. The record from 315-349 $\mathrm{m}$ depth from the Kai Islands (i) represents not only a new locality, but also a much shallower bathymetric range than that of type locality.

The ovigerous female from stn DW146 (vi) with the cornea large, about 0.18 of posterior orbital carapace length, pereiopod with the distoventral and subdistoventral spines of propod finely pectinate distodorsally, the second pereiopods similar and subequal.

\section{Distribution}

Type locality: Loyalty Islands. Now also known from Indonesia, Solomon Islands, Vanuatu, New Caledonia, and Fiji.

Periclimenes amboinensis (De Man, 1888)

Anchistia amboinensis De Man 1888, p 546-548, Plate 22a, Figure 2.

Periclimenes amboinensis: Borradaile 1898, p 385; Bruce 1991b, p 235; Chace and Bruce 1993, p 102; Bruce 1996, p 231, Figures 11h, i, 28f; Li 2000, p 153, Figure 187; Davie 2002, p 323.

\section{Material examined}

Phillipines: (i) Maribago, Mactan Island, Cebu, $10^{\circ} 17^{\prime} \mathrm{N}, 124^{\circ} 50^{\prime} \mathrm{E}, 3-5 \mathrm{~m}$, from mixed

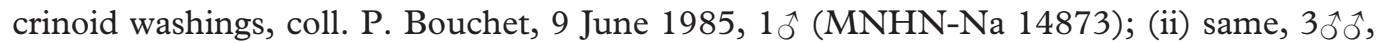
8ọ (4 ovig.) (MNHN-Na 14874); (iii) same, $10^{\circ} 17^{\prime} \mathrm{N}, 124^{\circ} 00 \mathrm{E}, 2-3 \mathrm{~m}, 3 \hat{\jmath} \mathrm{o}^{2}, 1$ ovig. ㅇ (MNHN-Na 14875); (iv) same, $1 \hat{\jmath}, 1$, (MNHN-Na 14876). New Caledonia: (v) Touho

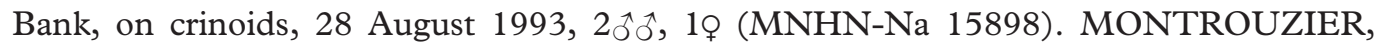
Touho, (vi) 5-7 m, coll. B. Richer de Forges, September 1993, 1 ovig. ㅇ (MNHN-Na 14872); (vii) $10 \mathrm{~m}$, scuba, from crinoids, 8 September 1993, $1 \widehat{0}$ (MNHN-Na 15809); (viii)

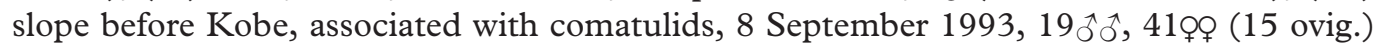
(MNHN-Na 15805). Loyalty Islands: ATELIER LIFOU, Lifou, Santal Bay, (ix) Chépenehe Bay, stn 1440, 20 47.2'S, $167^{\circ} 08.6^{\prime} \mathrm{E}, 15-35 \mathrm{~m}$, coral heads and pass

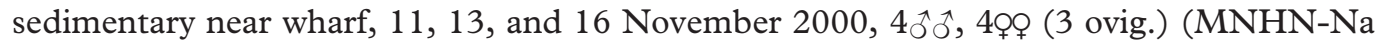
15872); (x) between Cap Mande and Cap Lefèvre (=Nem), stn 1452, 20 54.6'S, $167^{\circ} 02.1^{\prime} \mathrm{E}, 2-25 \mathrm{~m}$, scuba, 20 and 22 November 2000, 1 ovig. o (MNHN-Na 15533).

\section{Hosts}

(i) (ii) (iii) Comanthina schlegeli (P. H. Carpenter, 1882), Comatella nigra schlegeli (P. H. Carpenter, 1882), Comaster multibrachiata schlegeli (P. H. Carpenter, 1888), Comanthus 
bennetti (J. Müller, 1841); (iv) Comatella ?stelligera schlegeli (P. H. Carpenter, 1888), det. A. M. Clarke; (viii) comatulids; (ix) Tropiometra afra (Hartlaub, 1890) [Crinodea, Echinoderma].

\section{Parasites}

One male of (v) and one specimen of (x) have branchial bopyrid isopod parasites.

Remarks

Not previously reported from the Philippines. Recorded from Récif Amere, New Caledonia by Bruce (1991b). All the specimens have the telson with two pairs of dorsolateral spines located marginally, from barely discernible to very distinct, although all are very small. The wide range of morphological variation also present in rostral formula, hepatic spine and ambulatory propod. The rostral formula in the samples of (viii) varies from $0 / 0(3 \hat{\jmath} \hat{o}, 4$ oq),

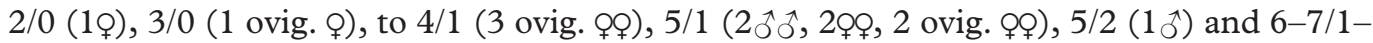
2 , most samples have the formula $7 / 1$. The hepatic spines vary from failing to reach the anterior carapace margin to reaching the margin (most samples), to exceeding the margin by distal one-quarter of the spine (most of the samples without or with fewer rostral teeth). Because of the series variation in the rostral formula and the hepatic spines, it is difficult to identify the samples of $(\mathrm{x})$ as $P$. amboinensis (De Man, 1888) or P. ceratophthalmus Borradaile, 1915. As most samples have a ventral rostral tooth, we treat the samples as $P$. amboinensis instead of $P$. ceratophthalmus temporarily until we check the type material of the two forms and more material. The wide range of variation and the diversity of host species suggest that a complex of closely related species exists possibly in association with the wide variety of host crinoids.

\section{Distribution}

Type locality: Ambon, Indonesia. Also known from Maldives, Indonesia, Australia (Western Australia, Queensland), New Caledonia, Loyalty Islands, and Marshall Islands.

Periclimenes attenuatus Bruce, 1971

Periclimenes attenuatus Bruce 1971b, p 533-543, Figures 1-5; Chace and Bruce 1993, p 103; Li 2000, p 159, Figure 196; Davie 2002, p 324; Li 2004a, p 68, Figures 1, 2.

\section{Material examined}

Philippines: Maribago, Mactan Island, Cebu, $10^{\circ} 17^{\prime} \mathrm{N}, 124^{\circ} 00^{\prime} \mathrm{E}, 2-3 \mathrm{~m}$, from mixed crinoid washings, coll. P. Bouchet, 9 June 1985, 1 ovig. ㅇ (MNHN-Na 14878).

Host

Comanthina schlegeli (P. H. Carpenter, 1881), det. A. M. Clark [Crinoides, Echinoderma].

\section{Remarks}

Not previously reported from the Philippines. The single specimen has a rostral dentition of $4 / 1$, with a very small ventral tooth. The first pereiopods have the carpus about three times longer than the chela, rather swollen distally; the fingers broad, densely setose laterally. Only the extremely slender minor second pereiopod is preserved. 


\section{Distribution}

Type locality: Duke of York Islands. Also known from Philippines, Indonesia, and Australia (Queensland).

Periclimenes brevicarpalis (Schenkel, 1902)

Ancylocaris brevicarpalis Schenkel 1902, p 563, Plate 13, Figure 21.

Periclimenes (Ancylocaris) brevicarpalis: Kemp 1922, p 185-191, Figures 40-42, Plate 67.

Periclimenes (Harpilius) brevicarpalis: Holthuis 1952a, p 69-73, Figure 27.

Periclimenes brevicarpalis: Bruce 1991b, p 236; Chace and Bruce 1993, p 104; Li 2000, p 161, Figure 199; Davie 2002, p 324; Li and Liu 2004, p 92, Figure 3.

\section{Material examined}

Madagascar: (i) northwest coast, Ambalatoaka, Nosy Be, coll. A. Crosnier, December 1958, 1 ô, 1o (MNHN-Na 14883); (ii) Nosy Be, intertidal, coll. A. Crosnier, September

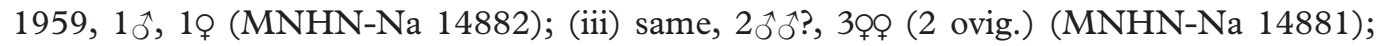
(iv) Tuléar, Grand Récif, with anemone Stoichactis sp., coll. R. Hipeau-Jacquotte, 1964, 2̧ิ龴⿵, 1 ovig. @ (MNHN-Na 15921); (v) Tuléar, Grand Récif, with anemone Stoichactis sp.,

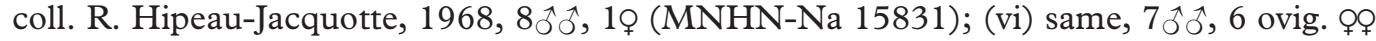

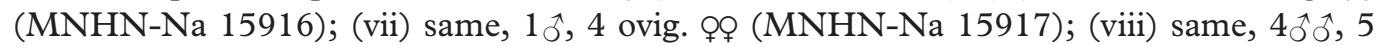
ovig. ọ (MNHN-Na 15919); (ix) Tuléar, Grand Récif, with anemone, coll. R. HipeauJacquotte, no date record, 1 (MNHN-Na 15924). New Caledonia: MONTROUZIER, (x) Ouanap, Koumac, $1 \mathrm{~m}$, on "choux-fleur (cabbage)" anemone, coll. S. Gofas, 19 October 1993, 1o (MNHN-Na 14879); (xi) Ouanap Bay, Koumac, intertidal, 22 October 1993, 10, 1@ (MNHN-Na 114880). Loyalty Islands: ATELIER LIFOU, Lifou, (xii) Santal Bay: Gaatcha Bay, stn 1463, 20 $55.05^{\prime} \mathrm{S}, 167^{\circ} 03.35^{\prime} \mathrm{E}, 20-30 \mathrm{~m}$, dredge, sand and corals, 10 November 2000, 1 ( (MNHN-Na 15534).

Host

(iv)-(viii) Stoichactis sp. (anemone) [Actinaria, Coelenterata].

\section{Remarks}

The specimens have a rostral dentition of either $5 / 1$ or $6 / 1$. The species has been previously recorded from Madagascar, from Toliara (Tuléar), by Hipeau-Jacquotte (1973) and Bruce (1978a), and from the Northwest Lagoon, New Caledonia, by Bruce (1991b).

\section{Distribution}

Type locality: “Makassar”' Indonesia. Also known from Gulf of Aqaba, Red Sea, Djibouti, Kenya, Zanzibar, Tanzania, Mozambique, Madagascar, Seychelles, Mauritius, Persian Gulf, Maldives, south India, Andaman Islands, Malaya, Singapore, Vietnam, South China Sea, Ryukyu Islands, Japan, Philippines, Indonesia, Papua New Guinea, Australia 
(Western Australia, Northern Territory, Queensland), Caroline Islands, Solomon Islands, New Caledonia, Loyalty Islands, and Marshall Islands.

Periclimenes brevirostris Bruce, 1991

Periclimenes brevirostris Bruce 1991a, p 321-330, Figures 15-20; Li 2000, p 163, Figure 200.

\section{Material examined}

Solomon Islands: (i) southwest Santa Isabel, stn CP2194, $8^{\circ} 24.8^{\prime} \mathrm{S}, 159^{\circ} 26.7^{\prime} \mathrm{E}, 440$ $521 \mathrm{~m}$, November 2004, 1 ovig. ㅇ (MNHN-Na 15951). Vanuatu: (ii) MUSORSTOM 8, stn CP1028, $17^{\circ} 54.01^{\prime} \mathrm{S}, 168^{\circ} 40.42^{\prime} \mathrm{W}, 624-668 \mathrm{~m}$, coll. B. Richer de Forges, 28 September 1994, 1 ( (MNHN-Na 15882). New Caledonia: (iii) BATHUS 1, stn CP709, $21^{\circ} 41.78^{\prime} \mathrm{S}, 166^{\circ} 37.88^{\prime} \mathrm{E}, 650-800 \mathrm{~m}, 19$ March 1993, 1 ovig. ㅇ (MNHN-Na 14884).

\section{Remarks}

Previously known only from the type material.

\section{Distribution}

Type locality: Île des Pins, New Caledonia, $500 \mathrm{~m}$. Known only from New Caledonia.

Periclimenes calcaratus Chace and Bruce, 1993

(Figure 15)

Periclimenes calcaratus Chace and Bruce 1993, p 104-105, Figure 21; Li 2000, p 165, Figure 203.

\section{Material examined}

Philippines: MUSORSTOM 3, stn CP103, $14^{\circ} 00^{\prime} \mathrm{N}, 120^{\circ} 18^{\prime} \mathrm{E}, 193-200 \mathrm{~m}$, 1 June 1985, 1 ๙ (MNHN-Na 14886).

\section{Remarks}

Previously known only from the type specimen from the Philippines.

\section{Distribution}

Type locality: Albay Gulf, Philippines, 267 m. Not known outside Philippines. 


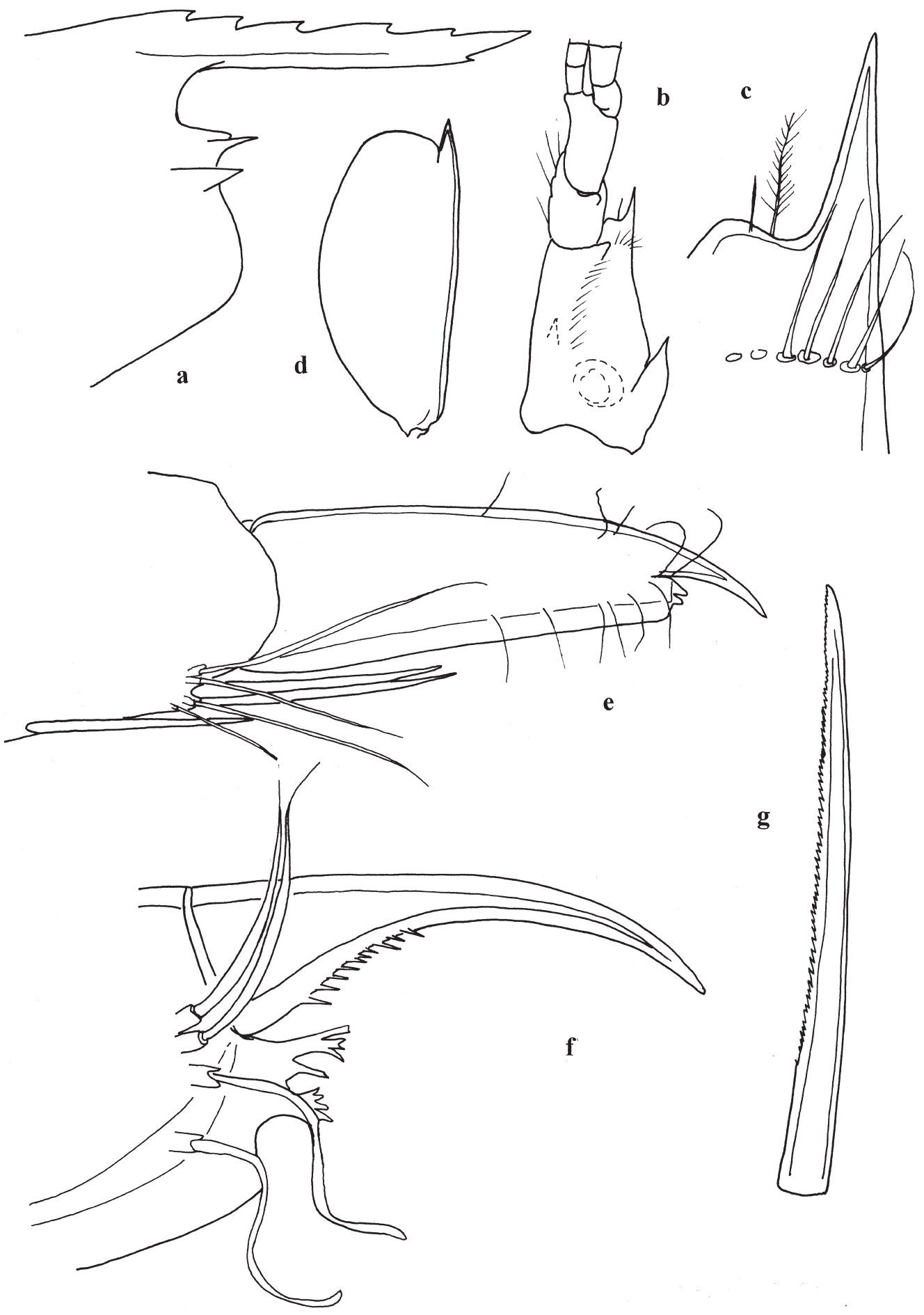

Figure 15. Periclimenes calcaratus Chace and Bruce, 1993, male (MNHN-Na 14886). (a) Anterior carapace; (b) antennule; (c) same, distolateral angle of proximal pedunclar segment; (d) antenna; (e) third pereiopod, distal propod and dactyl; (f) same, distal corpus and unguis; (g) distoventral propodal spine. 
Periclimenes ceratophthalmus Borradaile, 1915

Periclimenes (Corniger) ceratophthalmus Borradaile 1915, p 211.

Periclimenes (Ancylocaris) ceratophthalmus: Kemp 1922, p 172.

Periclimenes (Periclimenes) ceratophthalmus: Kemp 1925, p 324, Figure 18.

Periclimenes ceratophthalmus: Chace and Bruce 1993, p 106; Li 2000, p 167, Figure 206; Davie 2002, p 325.

\section{Material examined}

New Caledonia: (i) MONTROUZIER, 1993, Touho-Kohe, $15 \mathrm{~m}$, scuba, on comatulid crinoid, coll. B. Richer de Forge, 7 September 1993, 1 ovig. \& (MNHN-Na 14887). Loyalty Islands: (ii) ATELIER LIFOU, Lifou, Santal Bay: north of Cap Aimé Martin (=Acadro), stn $1447,20^{\circ} 45.8^{\prime} \mathrm{S}, 167^{\circ} 01.65^{\prime} \mathrm{E}, 17-31 \mathrm{~m}$, scuba, 17 and 22 November 2000, 1 ovig. $q$ (MNHN-Na 15535).

\section{Remarks}

Not previously recorded from New Caledonia and Loyalty Islands. The single sample of (i) has a rostral dentition of $4 / 1$ and has a single detached second pereiopod only. The cornea has an elongated terminal papilla and the dorsal telson spines are minute.

\section{Distribution}

Type locality: Hulule, Malé Atoll, Maldives. Also reported from Kenya, Zanzibar, Seychelles, Maldives, Indonesia, Australia (Queensland), Caroline Islands, Solomon Islands, New Caledonia, and Loyalty Islands.

\section{Periclimenes commensalis Borradaile, 1915}

Periclimenes (Cristiger) commensalis Borradaile 1915, p 211 ; Borradaile 1917, p 364. Periclimenes commensalis: Chace and Bruce 1993, p 107; Bruce 1996, p 232, Figure 12a-g; Li 2000, p 169, Figure 209; Davie 2002, p 325.

\section{Material examined}

Philippines: (i) Dumaran Channel, NE Palawan Islands, 2-3 m, washings from crinoids, coll. P. Bouchet, May 1985, 1 ô, 4ọ (2 ovig.) (MNHN-Na 14888); (ii) Maribago, Mactan Island, Cebu, $10^{\circ} 17^{\prime} \mathrm{N}, 124^{\circ} 00^{\prime} \mathrm{E}, 3-5 \mathrm{~m}$, washings from crinoids, coll. P. Bouchet, 9 June

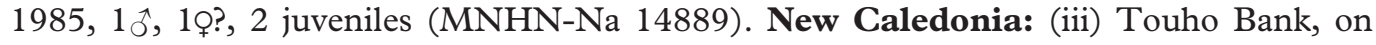

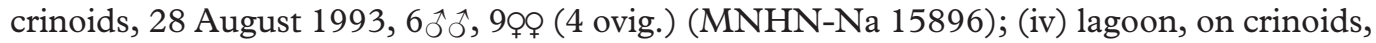
30 August 1993, 8ọ (2 ovig.) (MNHN-Na 15847); (v) Touho, Kohe, 8 September 1993, 3ิึิ, 2Q̣̊ (MNHN-Na 15888).

\section{Hosts}

(i) (ii) Comanthina schlegeli (P. H. Carpenter, 1881); (ii) also Comatella nigra (P. H. Carpenter, 1888), Comanter multibrachiata (P. H. Carpenter, 1888), Comanthus bennetti (J. Müller, 1841); det. A. M. Clark. (v) Comatella sp. [Crinodea, Echinoderma].

\section{Parasites}

A branchial bopyrid is present on one of the specimens from Maribago. A bopyrid is also present beneath the abdomen of one male (iii). A couple of bopyrids are present beneath the abdomen of one female (v). 
Remarks

Not previously recorded from the Philippines. Previously reported from Nouméa, New Caledonia, by Monod (1976). The Dumaran Channel specimens were collected in association with Palaemonella pottsi and Periclimenes affinis. The Touho specimens were found with Periclimenes amboinensis.

The majority of specimens still have both second pereiopods attached. The chelae are subequal and similar, short and stout, about 1.2 times the carapace length, with a wellmarked "ball and socket" articulation with the similarly stout carpus. The distal cutting edges of the fingers are minutely serrate. The ambulatory dactyl of the third pereiopod is biunguiculate with a clearly demarkated unguis, the proximal dorsal aspect of which bears a strong central non-articulated spiniform tooth, flanked medially and laterally by smaller similar teeth, not always readily visible. The propod is sparsely setose and the spines are distally dentate as reported in Bruce (1980a, 1982, 1996). Borradaile (1915, 1917) did not provide any illustrations with his description of the type material of this species. The second specimen discovered unfortunately lacked the second pereiopods (Holthuis 1952a). Miyake and Fujino (1968), reporting on specimens from the Palau Islands, were the first to describe and illustrate the second pereiopods but they did not comment on the carpopropodal articulation. Monod (1976) described and illustrated a specimen from New Caledonia but did not provide information on the second pereiopods. Bruce (1980a) similarly omitted reference to these appendages in reporting on a juvenile associated with a holothurian host in the Solomon Islands. These descriptions also illustrate the ambulatory dactyls, but show or describe only a single simple dorsal spine and not a trifid spine as in the present specimens.

\section{Distribution}

Type locality: Murray Island, Torres Strait. Also known from Kenya, Zanzibar, Mozambique, China (Hong Kong), Japan, Philippines, Indonesia, Australia (Northern Territory, Queensland, Elizabeth and Middleton Reefs), Tasman Sea, Caroline Islands, Solomon Islands, New Caledonia, Marshall Islands, and Fiji.

Periclimenes cristimanus Bruce, 1965

Periclimenes cristimanus Bruce 1965, p 487-493, Figures 1, 2; Chace and Bruce 1993, p 108; Li 2000, p 173, Figure 215; Davie 2002, p 326.

\section{Material examined}

Philippines: Maribago, Mactan Island, Cebu, $10^{\circ} 17^{\prime} \mathrm{N}, 124^{\circ} 00^{\prime} \mathrm{E}, 0.5-2 \mathrm{~m}$, washings from crinoids, coll. P. Bouchet, 10 June 1985, 1 ovig. o, 2 juveniles (MNHN-Na 14890).

Host

Echinothrix calamaris (Pallas, 1774) [Echinoidea, Echinoderma].

\section{Remarks}

Not previously recorded from the Philippines.

\section{Distribution}

Type locality: Pulau Sudong, Singapore. Also known from Malaya, China (Hong Kong), Philippines, Australia (Queensland), and the Marshall Islands. 
Periclimenes crosnieri sp. nov.

(Figures 16-18)

\section{Material examined}

Indonesia: KARUBAR, Tanimbar Islands, stn CP45, 7 $54^{\prime} \mathrm{S}, 132^{\circ} 47^{\prime} \mathrm{E}, 302-305 \mathrm{~m}, 29$ October 1991, o holotype (cl $5.81 \mathrm{~mm})$; $\propto$ paratype (cl $5.68 \mathrm{~mm})(\mathrm{MNHN}-\mathrm{Na} 14943)$.

\section{Description}

Holotype. A medium body size pontoniine shrimp of subcylindrical body form.

Carapace smooth, glabrous. Rostrum well developed, moderately deep, compressed, extending beyond antennular peduncle, about 0.67 of carapace length, not reaching distal margin of scaphocerite, anteroventrad proximally, upcurved distally; dorsal carina deep, with seven subequal, evenly distributed along whole length, teeth acute, first tooth situated just above posterior orbital margin; lateral carinae feebly developed, slightly upcurved distally; ventral carina deep distal half, with two low acute teeth on distal third, smaller than dorsal teeth; interdental spaces and proximal ventral carina feebly setose. Supraorbital spine absent, epigastric spine situated at anterior 0.25 of the carapace length; orbit feebly developed, inferior orbital angle strongly produced, bluntly round in dorsal view; antennal spine small slender marginal, distinctly below inferior orbital angle, not exceeding inferior orbital angle; hepatic spine larger than antennal spine, slender, below level of antennal spine, below and between epigastric spine and first dorsal rostral tooth in lateral view; anterolateral angle of carapace not produced, bluntly rounded.

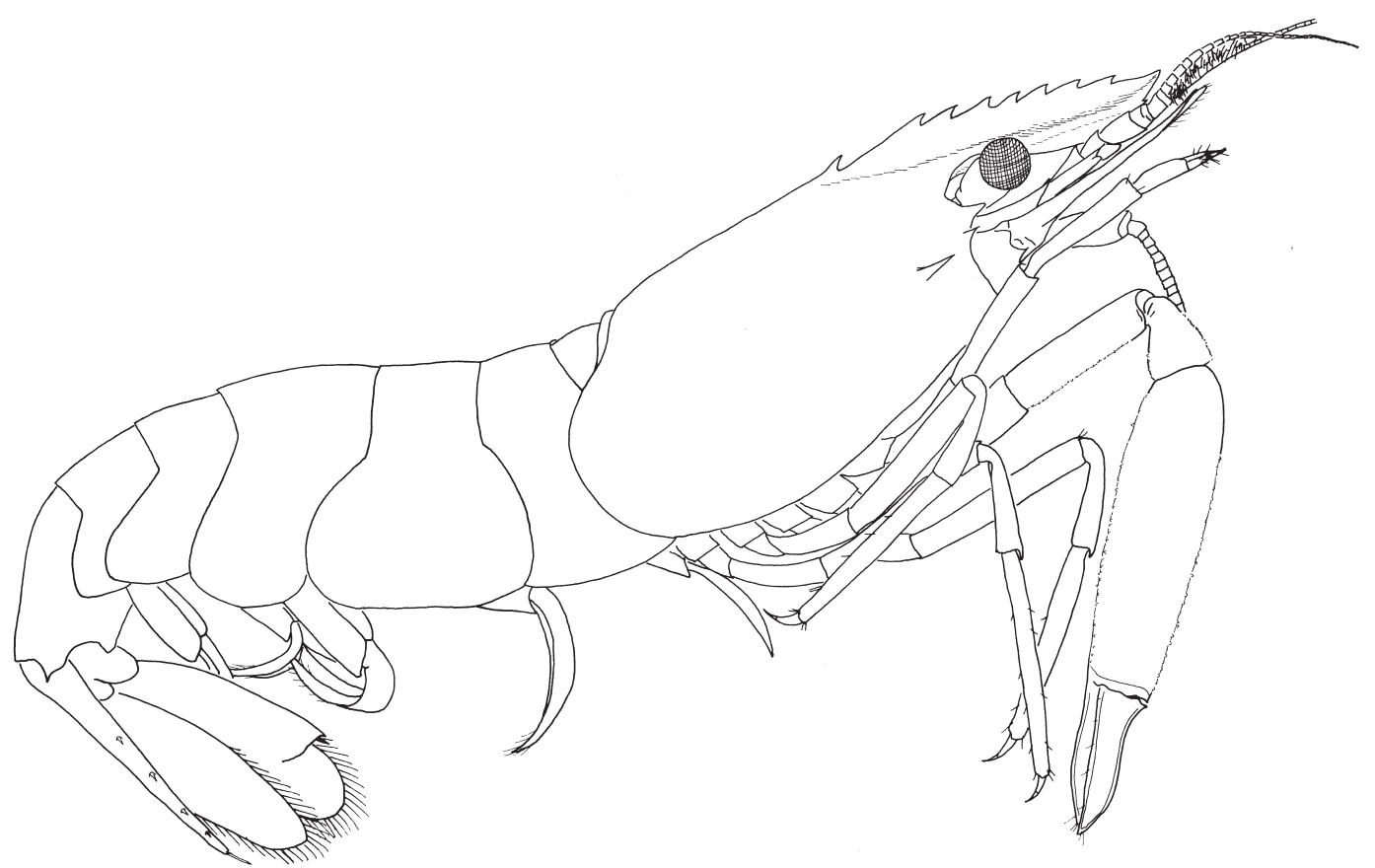

Figure 16. Periclimenes crosnieri, new species, holotype female (MNHN-Na 14943), body, lateral view. 


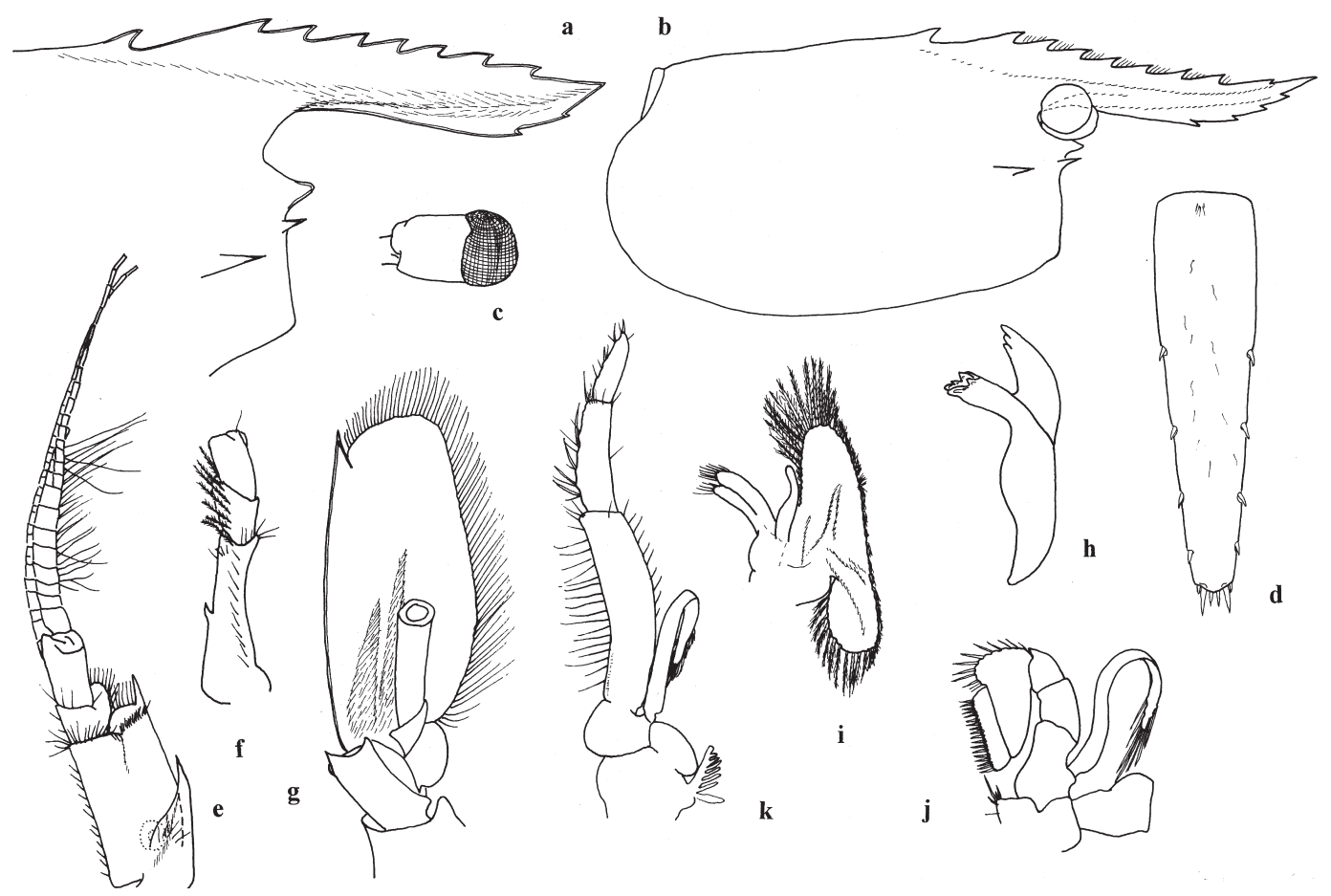

Figure 17. Periclimenes crosnieri, new species. (a, c-k) Holotype female; (b) paratype female (MNHN-Na 14943). (a) Anterior carapace; (b) carapace; (c) right eye, lateral view; (d) telson; (e) right antennule; (f) same, peduncle, medial view; (g) right antenna; (h) mandible; (i) maxilla; (j) second maxilliped; $(\mathrm{k})$ third maxilliped.

Abdominal segments smooth, glabrous; sixth segment about 1.57 times length of fifth, subcylindrical, about 1.53 times longer than deep, subuniform, posterolateral angle acute, posteroventral angle rounded; pleura of first three segments small, broadly rounded, fourth and fifth posteriorly produced, bluntly rounded. Telson about 1.64 times sixth segment length, about 3.6 times longer than anterior width, lateral margins with anterior third curved ventrally, posterior two-thirds straight, convergent, posterior margin about 0.36 of anterior margin width, rounded, without posterior median point; dorsal surface with sparse long setae, with four pairs of small but well-developed dorsolateral spines at $0.41,0.59$, 0.76 , and 0.88 of telson length; three pairs of posterior spines, lateral spines short, similar to dorsal spines, about 0.02 of telson length, intermediate spines long, robust, about 0.08 of telson length, submedian spines robust, about 0.43 of intermediate spine length.

Eye small, with feebly pigmented globular cornea, diameter of cornea 0.14 of posterior orbital carapace length, without accessory pigment spot; stalk subequal to corneal diameter, subequal to its width.

Antennular peduncle overreaching to seventh dorsal rostral tooth; proximal segment about 2.0 times longer than central width, with slender acute stylocerite laterally, reaching to about 0.7 of segment length, anterolateral margin feebly produced, setose, with long slender acute lateral tooth reaching to the end of dorsal margin of intermediate segment; statocyst small; medial margin setose, with ventromedial tooth at about 0.5 of length; intermediate segment obliquely articulated with distal segment, dorsal length about 0.25 of proximal segment length, 0.7 of width, lateral margin expanded, setose; distal segment 


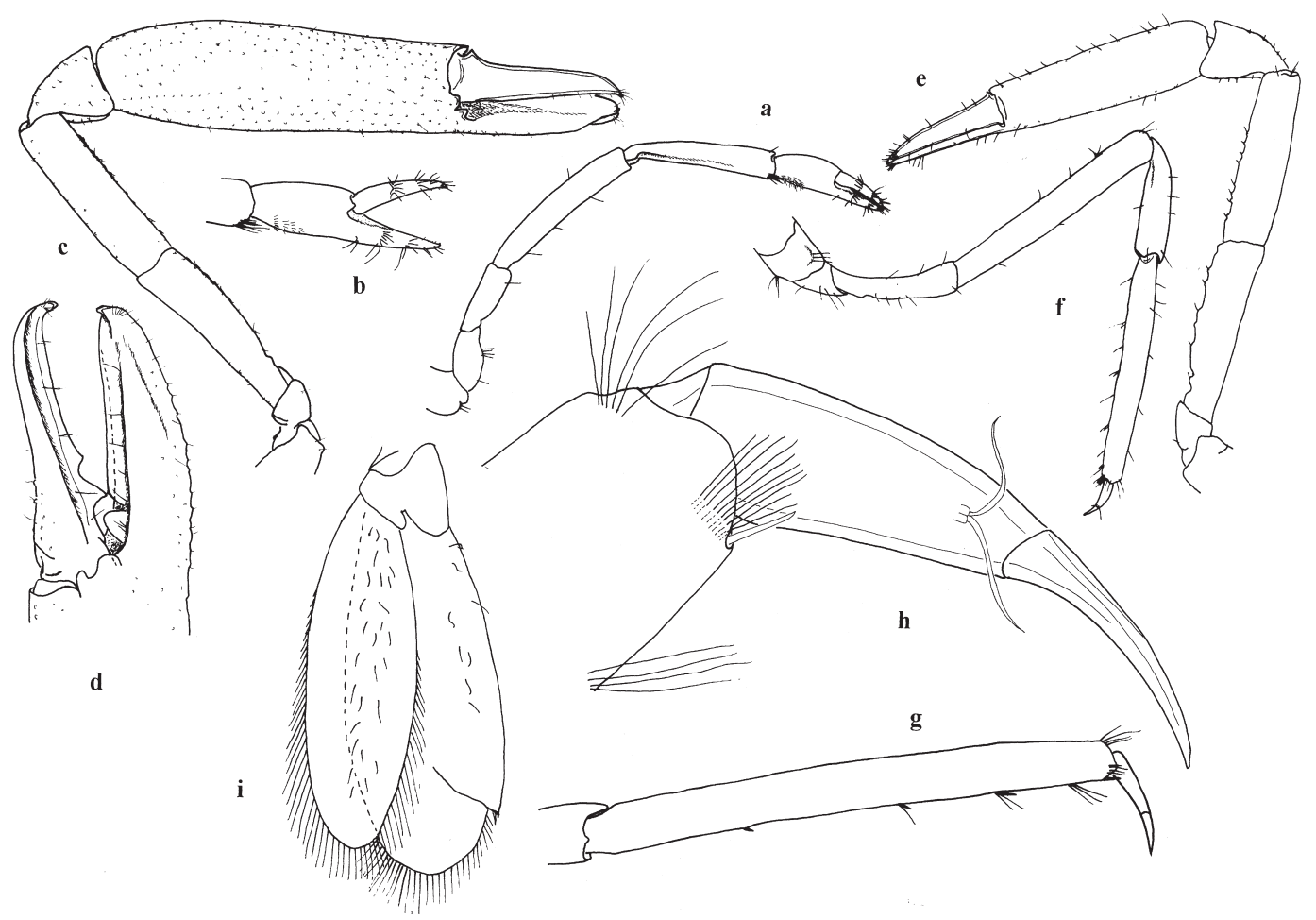

Figure 18. Periclimenes crosnieri, new species. (a-f, i) Holotype female; (g, h) paratype female (MNHN-Na 14943). (a) First pereiopod; (b) same, chela; (c) major second pereiopod; (d) same, fingers; (e) minor second pereiopod; (f) third pereiopod; (g) same, propod and dactyl; (h) same, distal propod and dactyl; (i) uropod.

about 2.1 times intermediate segment length, 0.46 of proximal segment length, slender, about 1.9 times longer than distal width; upper flagellum biramous, with eight proximal segments of rami fused, shorter free ramus with five segments, length about 0.46 of fused portion, total length about 0.38 of carapace length, with about 17 groups of aesthetascs; longer ramus, slender, filiform, about 0.45 times carapace length; lower flagellum slender, filiform, about 0.73 times carapace length.

Antennal basicerite robust, with acute lateral tooth; carpocerite about 0.45 of length of lateral margin of scaphocerite, about 3.8 times longer than width, subcylindrical, reaching about 0.42 of total length of scaphocerite; flagellum well developed, slender, about 2.6 times postorbital carapace length; scaphocerite well developed, distinctly exceeding tip of rostrum, broad, about 2.1 times longer than wide, greatest width at about 0.4 of length, distal margin bluntly rounded, lateral margin feebly convex, with strong acute distolateral tooth, reaching near to distal lamella.

Epistome unarmed. Fourth thoracic sternite without slender median process, with low transverse ridge with shallow median notch; posterior sternites narrow.

Mouthparts typical of the genus. Mandible with corpus moderately robust, without palp; molar process normal, with four strong blunt teeth, lower inner tooth bilobed; incisor process robust, obliquely truncate distally with three stout acute teeth, central tooth smaller than outer teeth. Maxilla with short simple non-setose palp; basal endite deeply bilobed, upper lobe stouter than lower, with simple setae distally; coxal endite obsolete, medial 
margin convex; scaphognathite well developed, about 3.2 times longer than central width, posterior lobe about 0.34 of scaphocerite length, 1.5 times longer than wide, anterior lobe with median margin concave, about 1.7 times longer than wide. Second maxilliped with normal endopod, dactylar segment about 4.0 times longer than broad, with numerous serrulate spines medially; propodal segment broad, with distal margin with numerous long finely serrulate spiniform setae; carpus, ischiomerus and basis without special features; coxa angularly produced medially, with four to five simple setae; exopod with slender flagellum with eight to nine plumose setae distally; epipod simple, without podobrach. Third maxilliped with slender endopod, extending distally to the middle of the carpocerite, ischiomerus and basis fused incompletely, basal portion medially expanded, convex, combined segment length about 5.0 times central width, compressed, setose medially, with submarginal row of 15-17 very short small spines on proximal medial ischial portion; intermediate segment about 0.45 of combined proximal segment length, 3.2 times longer than central width, with several groups of long finely serrulate spiniform setae medially; terminal segment about 0.3 of combined proximal segment length, distally tapering, about 3.2 times longer than proximal width, with sparse spiniform setae medially, with long distal spines; exopod with slender flagellum with 12-14 plumose setae distally; coxa feebly produced medially, with oval lateral plate; arthrobranch distinct.

First pereiopods moderately slender, exceeding tip of rostrum by length of chela; chela with palm subcylindrical, slightly compressed, about 2.0 times longer than maximal depth, at about proximal 0.4 of length with several tranverse rows of short cleaning setae proximoventrally; finger subequal to palm length, slender, tapering, cutting edges sharp, entire, tips hooked, base slightly expanded, surrounded by palisade of short curved setae medially and laterally, carpus about 1.3 of chela length, 5.0 times longer than distal width, tapering proximally, with seven to eight serrulate cleaning setae distoventrally; merus about 1.4 times chela length, 5.4 times longer than central width; ichium 1.1 of palm length, 2.75 times longer than distal width, not strongly carinate distoventrally, obliquely articulated with basis; basis about 0.34 of carpus length; coxa without ventromedial process.

Second pereiopods well developed, generally similar, unequal. Major (right) second pereiopod exceeding carpocerite by chela and carpus; chela about 1.33 times carapace length, palm subcylindrical, subuniform, with small tubercles, some of the tubercles with short and fine setae on tip, about 3.4 times longer than maximal depth, fingers about 0.45 of palm length, with stout hooked tips and both with well-developed lateral flanges, lateral surfaces with small tubercles similar to those of palm; dactyl about 3.8 times longer than proximal depth, with developed lateral flange, 0.6 distal cutting edge entire, large triangular acute tooth at proximal quarter, notch present distal to and proximal to tooth, respectively; fixed finger stouter than dactyl, with well-developed lateral flange, cutting edge with large pit at base, large tooth with rounded tip present in pit, distal three-quarters cutting edge entire; carpus about 0.22 of palm length, 1.1 times longer than distal width, cup-like, feebly excavate distally, proximally tapered, armed with small tubercles similar to palm; merus about 0.5 of palm length, subuniform, about 3.65 times longer than distal depth, armed with sparse small tubercles, without distoventral tooth; ischium about 0.5 of palm length, subequal to merus length, 3.66 times longer than distal width, slightly dorsoventrally compressed, slightly proximally tapered, armed with sparse small tubercles; basis and coxa normal. Minor (left) pereiopod exceeding carpocerite by chela and distal two-thirds of carpus; chela about 0.81 times postorbital carapace length, 0.62 times length of major chela; palm about 3.5 times longer than maximal depth, with very sparse small tubercles; fingers about 0.5 of palm length, with strongly hooked tips, cutting edges entire, sharp, with 
feebly dentition proximally; dactyl about 4.8 times longer than proximal depth, with feebly developed lateral flange; carpus cup-like, about 0.33 of palm length, 1.2 times the distal width, with scattered small tubercles; merus about 0.84 of palm length, subequal to ischium, with tubercles ventrally; basis and coxa normal.

Ambulatory pereiopods robust. Third pereiopod exceeds carpocerite by dactyl, propod, and distal quarter of carpus; dactyl compressed, curved, about 0.22 of propod length, unguis distinct, about 0.75 of dorsal length of corpus, corpus about 2.5 times longer than proximal depth, ventral margin unarmed, without distal accessory tooth, with two distolateral sensory setae; propod about 0.51 of carapace length, 6.8 times longer than maximum wide, slightly tapered distally, with pair of short slender simple distoventral spines, three single spines distributed on ventral margin, and transverse rows of long setae distolaterally; carpus about 0.52 of propod length, 3.65 times longer than distal width, unarmed; merus 1.08 of propod length, 6.5 times longer than wide, uniform, unarmed; ischium subequal to carpus length, 0.5 of merus length, 3.45 times longer than distal width, slightly tapered proximally; basis and coxa without special features. Fourth and fifth pereiopods similar to third, fourth propod subequal, fifth propod 1.1 times third propod length, less strongly spinose distoventrally; fifth exceeds carpocerite by dactyl and distal three-fifths propod, with propod with transverse rows of cleaning setae distolaterally.

Uropod distinctly exceeding telson; protopodite with posterolateral angle short, rounded; exopod 2.4 times longer than central width, lateral border distinctly convex, with small acute distal tooth, with large mobile spine medially, diaeresis distinct; endopod about 0.9 of exopod length, 3.0 times longer than wide.

Paratype. Similar to holotype. Rostrum longer than that of the holotype, 0.77 of carapace length, but not reaching the distal end of scaphocerite, lower than that of holotype, dorsal margin slightly concave, with eight dorsal and four ventral teeth, interdental spaces and with distinct short setas. Telson regenerated and soft except the extreme base, the four dorsolateral spines distinct along right margin, obscure along left margin.

\section{Measurements (mm)}

Holotype. Female, carapace length, 5.81; carapace and rostrum, 10.19; second pereiopod, major chela, 7.74 ; minor chela, 4.80 .

Paratype. Female, carapace length, 5.68; carapace and rostrum, 10.03; second pereiopod, major chela, 8.47; minor chela, 5.57 .

\section{Systematic position}

In its general morphology, particularly the telson with four pairs of dorsolateral spines, major second pereiopods with lateral flange on the fingers and palms covered with fine tubercles, and shape of the rostrum, Periclimenes crosnieri sp. n. shows a close resemblance to $P$. aleator Bruce, 1991 and other species of the " $P$. alcocki species group". It can immediately be distinguished from these species by the presence of a simple nonbiunguiculate dactyl on the ambulatory pereiopods. It is similar to P. uniunguiculatus Bruce, 1990, P. granuloides Hayashi, 1986, P. foresti Bruce, 1981, or other deep-water species with a simple dactyl on the ambulatory pereiopods. It can easily be distinguished from those species by the telson with four pairs of dorsolateral spines, and also the well-developed lateral flange on the major second pereiopod. 
Etymology

The specific name is given in honour of the French carcinologist, Alain Crosnier.

\section{Remarks}

Telson with four pairs of dorsolateral spines may show that Periclimenes crosnieri n. sp. belongs to the "Periclimenes alcocki species group", but the simple dactyl on the ambulatory pereiopods indicates that it is separated from the other members of the group. Captured at a depth of 302-305 m, occurs in shallower depth than $P$. alcocki and $P$. aleator, but at similar depth with $P$. albatrossae Chace and Bruce, 1993, which has seven pairs of dorsolateral spines on telson.

Periclimenes forcipulatus Bruce, 1991

Periclimenes forcipulatus Bruce 1991a, p 330, Figures 21-25; Li 2000, p 181, Figure 22.

\section{Material examined}

Solomon Islands: SALOMON 1, stn DW 1854, $9^{\circ} 46.4^{\prime} \mathrm{S}, 160^{\circ} 52.9^{\prime} \mathrm{E}, 229-260 \mathrm{~m}, 7$ October 2001, 1Q (MNHN-Na 15536).

\section{Remarks}

Not previously recorded from Solomon Islands. The present record extends the bathymetric range to the shallower depth of $229 \mathrm{~m}$.

\section{Distribution}

Type locality: Loyalty Islands, New Caledonia, $460 \mathrm{~m}$. Now also known from Solomon Islands.

\section{Periclimenes forgesi sp. nov.}

(Figures 19, 20)

\section{Material examined}

New Caledonia: (i) BATHUS 3, stn CP846, 230 02.90'S, $166^{\circ} 57.97^{\prime} \mathrm{E}, 500-514 \mathrm{~m}, 1$ December 1993, 1 ovig. O holotype (MNHN-Na 14928); (ii) NORFOLK 1, Norfolk Ridge, stn CP1670, 2339'S, $167^{\circ} 59^{\prime} \mathrm{E}, 382-386$ m, Banc Jumeau-ouest, 21 June 2001, 1 ovig. o paratype (MNHN-Na 15869).

\section{Description}

A medium to large body size pontoniine shrimp of subcylindrical body form. Holotype with right scaphocerite, first, second, fourth and fifth pereiopods, most of telson except proximal part anterior to anterior pair of dorsolateral spines, uropod with distal part posterior to diaeresis lost; right third pereiopod and left fourth merus to dactyl detached; both hepatic spines and first three dorsal rostral teeth broken basally. Paratype with the tip of rostrum broken, right fourth, left fourth and fifth pereiopods lost; dactyl of left (major) second pereiopod lacking. 


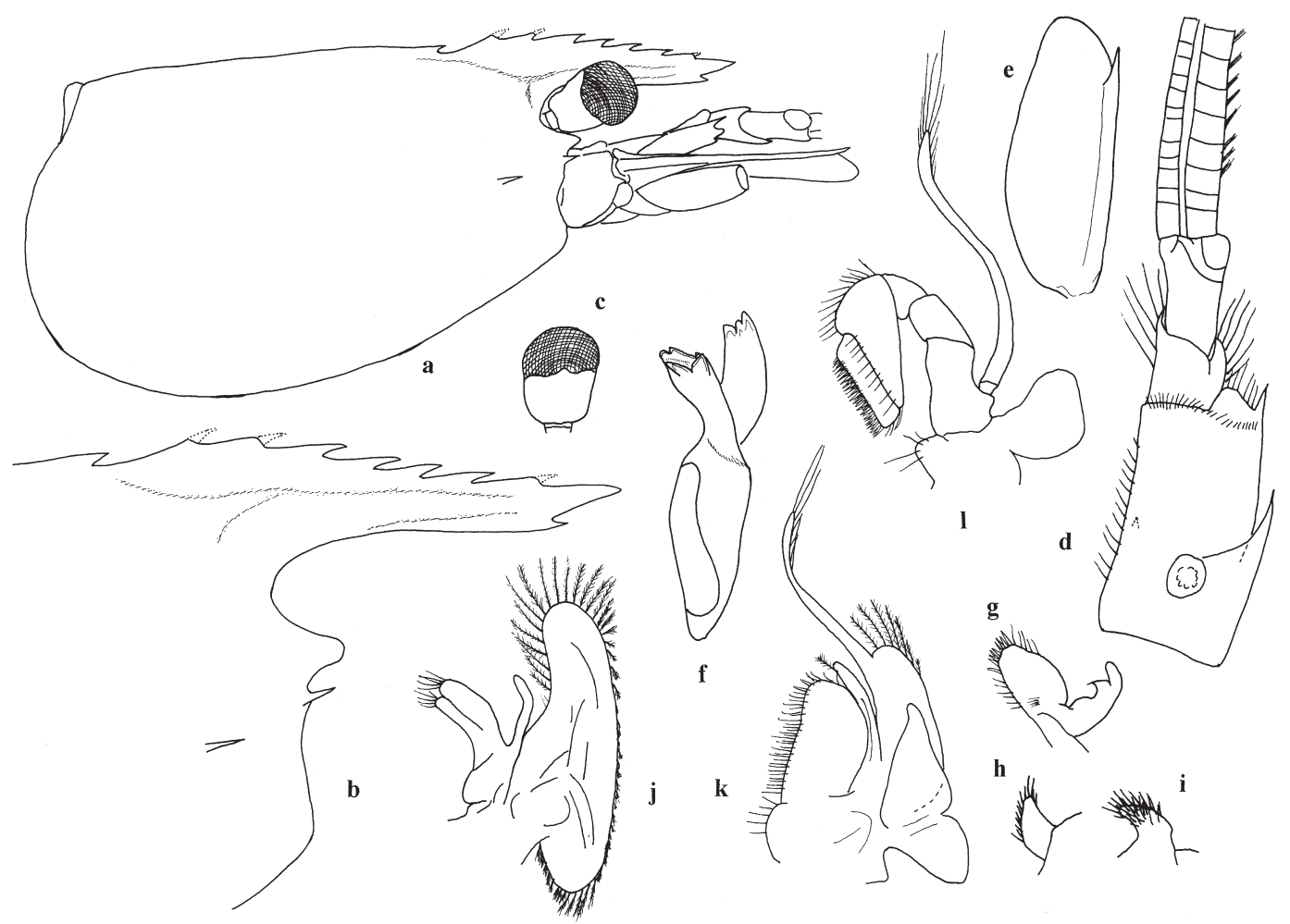

Figure 19. Periclimenes forgesi, new species, holotype ovigerous female (MNHN-Na 14928). (a) Carapace and anterior appendages; (b) anterior carapace; (c) eye; (d) antennule; (e) antenna; (f) mandible; (g) maxillula, upper lacinia and palp; (h, i) same, lower lacinia; (j) maxilla; (k) first maxilliped; (l) second maxilliped.

Holotype. Carapace smooth, glabrous. Rostrum short, slender, compressed, reaching to distodorsal end of second segment of antennular peduncle, about 0.42 of carapace length, feebly expanded laterally proximally, with feeble crest on proximal part and tapering distally; dorsal margin with seven small subequal acute teeth, more or less evenly distributed along whole length, second tooth situated just above posterior orbital margin; lateral carinae feebly developed; ventral margin straight, with one small acute tooth at distal 0.18 of rostral length, anterior to the distal dorsal tooth. Supraorbital spine absent, epigastric spine situated at anterior 0.21 of carapace length, distinctly smaller than dorsal rostral teeth; orbit feebly developed, inferior orbital angle produced, bluntly round; antennal spine small, slender, marginal, distinct below inferior orbital angle, not exceeding inferior orbital angle; hepatic spine feebly larger than antennal spine, small, slender, slightly below level of antennal spine, at level of first dorsal rostral tooth in lateral view; anterolateral angle of carapace not produced, bluntly rounded.

Abdominal segments smooth, glabrous; pleura of first three segments broadly rounded, fourth and fifth posteriorly produced, bluntly rounded; third segment without dorsal prominence; sixth segment about 1.7 times length of fifth, subcylindrical, about 1.75 times longer than deep, subuniform, posterolateral and posteroventral angles bluntly angulate.

Eye normally developed, cornea globular, well pigmented, diameter 0.16 of postorbital carapace length, without accessory pigment spot; stalk feebly compressed, feebly tapered proximally, 0.63 of corneal diameter and 0.74 of central width. 


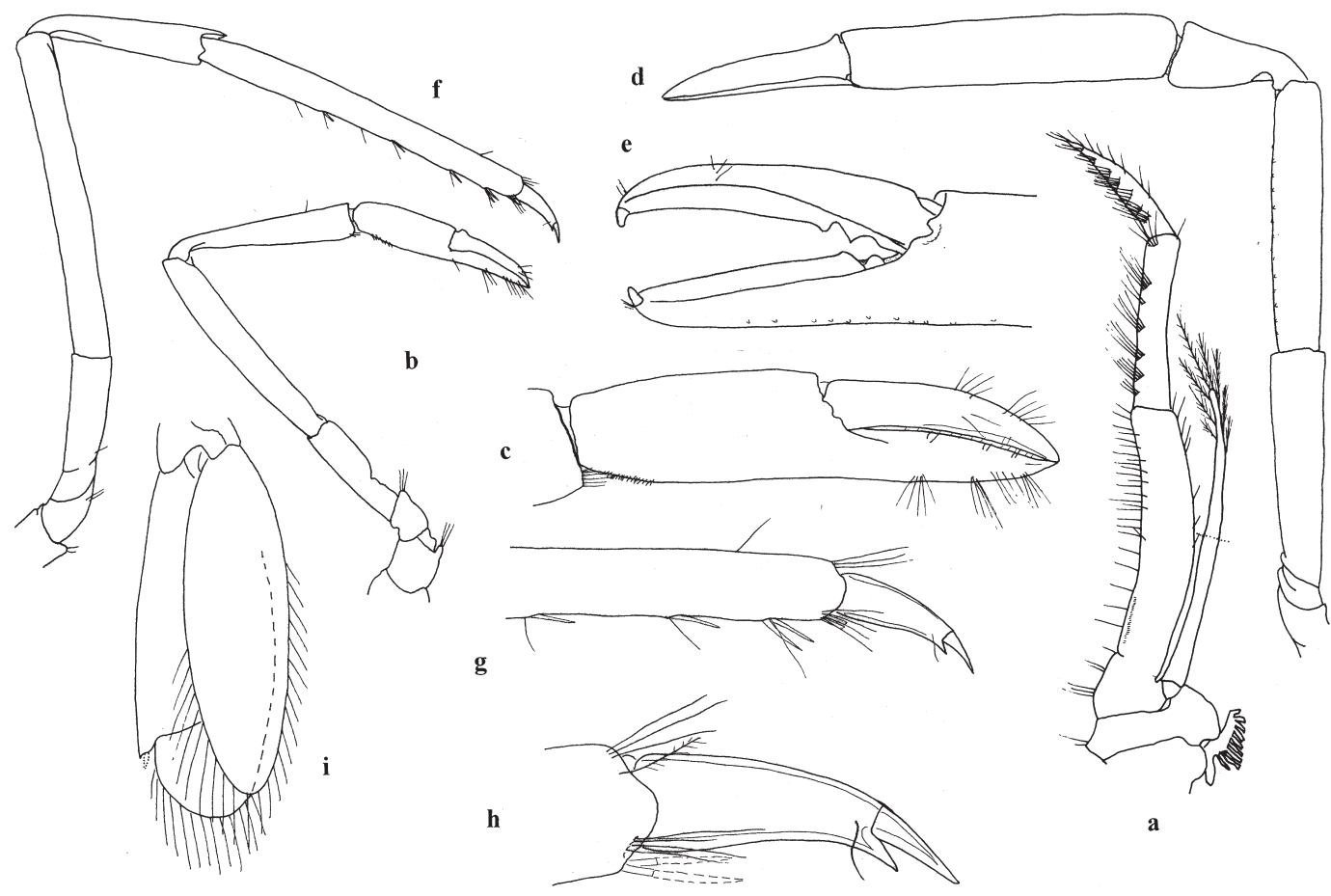

Figure 20. Periclimenes forgesi, new species, holotype ovigerous female (MNHN-Na 14928). (a) Third maxilliped; (b) first pereiopod; (c) same, chela; (d) second pereiopod; (e) same, fingers; (f) third pereiopod; (g, h) same, distal propod and dactyl; (i) uropod.

Antennular peduncle overreaching rostrum by third segment; proximal segment 1.85 times longer than central width, with slender acute stylocerite laterally, reaching to about 0.7 of segment length, anterolateral margin produced, setose, with long slender acute lateral tooth overreaching middle dorsal length of intermediate segment; statocyst small; medial margin straight, with plumose setose, ventromedial tooth minute, at about 0.5 of length. Intermediate segment obliquely articulated with distal segment, dorsal margin oblique proximolaterally, middle dorsal length about 0.26 of proximal segment length, 1.1 times width (not including lateral lobe), lateral margin expanded, with long robust plumose setae, medial margin similarly setose to lateral margin. Distal segment with mid-dorsal length 0.42 of proximal segment length, 1.4 times longer than distal width; upper flagellum biramous, with 10 proximal segments of rami fused, shorter free ramus with six segments, length about 0.64 of fused portion, total length about 0.53 of carapace length, with 22 groups of aesthetascs; longer ramus (free portion) slender, filiform, about 0.83 times carapace length; lower flagellum slender, filiform, subequal to carapace length.

Antennal basicerite robust, with acute distolateral tooth; carpocerite robust, 2.7 times longer than width, subcylindrical, reaching about 0.46 of total length of scaphocerite; scaphocerite well developed, exceeding antennular peduncle by distal third of lamella, broad, 2.5 times longer than wide, greatest width at about 0.4 of length, distal margin produced, bluntly rounded, distinctly overreaching distolateral tooth, lateral margin straight, with strong acute distolateral tooth. 
Epistome unarmed. Fourth thoracic sternite without slender median process, with low transverse ridge with a median notch posteriorly; fifth thoracic sternite with similar ridge, posterior sternites unarmed.

Mouthparts typical of the genus. Mandible without palp; molar process normal, with four strong blunt teeth, lower inner tooth bilobed; incisor process robust, obliquely truncate distally with three (left) or four (right) stout teeth, central tooth smaller than outer teeth. Maxillula with palp bilobed, lower lobe shorter, acute tip with very short seta, upper lobe longer, with rounded tip; upper lacinia oval, with 10 spines distally and scattered setae; lower lacinia slender, tapered with numerous spiniform setae distally and simple setae on outer surface. Maxilla with short simple non-setose palp; basal endite deeply bilobed, upper lobe stouter than lower, with simple setae distally; coxal endite obsolete, medial margin convex; scaphognathite well developed, about 2.9 times longer than central width. First maxilliped with elongate slender palp, with short setulose preterminal seta; basal endite large, broad, setose medially; coxal endite distinct, convex; exopod with normal flagellum with four plumose distal setae and simple setae on distal half laterally; caridean lobe well developed, broad; epipod large, triangular, bilobed. Second maxilliped with normal endopod, dactylar segment about 3.5 times longer than broad, with numerous serrulate spines medially; propodal segment broad, with distal margin with long spiniform setae; carpus, ischiomerus and basis without special features; coxa angularly produced medially, with four to five simple setae; exopod with slender flagellum with eight to nine plumose setae distally; epipod simple, without podobrach. Third maxilliped with slender endopod, exceeding carpocerite by distal quarter of terminal segment; ischiomerus and basis incompletely fused, border indicated only by medial notch, basal portion feebly expanded medially, combined segment length about 6.0 times central width, compressed, setose medially, with submarginal row of very short small spines on proximal medial ischial portion; intermediate segment about 0.58 of combined proximal segment length, 6.0 times longer than central width, with six groups of long finely serrulate spiniform setae medially; terminal segment about 0.44 of combined proximal segment length, distally tapering, about 4.8 times longer than proximal width, with seven groups of spiniform setae medially, and long spiniform distal setae; exopod with slender flagellum with about 10 plumose setae distally; coxa feebly produced medially, with oval lateral plate; arthrobranch distinct.

First pereiopods moderately slender, exceeding carpocerite by chela and distal five-sixths carpus; chela with palm subcylindrical, slightly compressed, about 2.25 times longer than depth, with six tranverse rows of short cleaning setae proximoventrally; finger subequal to palm length, slender, tapering, cutting edges sharp, entire, tips hooked, surrounded by four groups of palisade setae medially and laterally on distal half, setae shorter distally; carpus about 0.93 of chela length, 5.45 times longer than distal width, tapering proximally, with one row two groups serrulate cleaning setae distoventrally, outer group with eight long setae, inner group with six short setae, about half as long as the long setae; merus about 1.2 times chela length, 7.0 times longer than central width; ichium 0.6 of chela length, 3.3 times longer than distal width, not strongly carinate distoventrally, obliquely articulated with basis; basis and coxa without special features.

Left (minor) second pereiopod well developed, exceeding carpocerite by chela, carpus and distal third of merus, rostrum by chela and carpus; chela about 0.95 times carapace length, palm subcylindrical, subuniform, with sparse small tubercles on medial (fixed finger side) surface, about 4.8 times longer than maximal depth, fingers about 0.6 of palm length, with stout hooked tips and feebly developed lateral flanges, fixed finger stouter than dactyl, with few scattered small tubercles on lateral surfaces similar to those of palm, cutting edge 
with distal 0.72 entire, small tooth on proximal 0.23 and small blunt rounded tooth in proximal pit; dactyl about 3.6 times longer than proximal depth, cutting edge with distal 0.64 entire, two small teeth and two notches on proximal 0.36 , proximal tooth larger and triangular; carpus cup-like, about 0.34 of palm length, 1.76 times longer than distal width, feebly excavate distally, proximally tapered; merus about 0.83 of palm length, subuniform, about 5.5 times longer than distal depth, armed with sparse small tubercles on flexor margin, without distoventral tooth; ischium about 0.8 of palm length, subequal to merus length, 4.7 times longer than distal width, feebly compressed, slightly proximally tapered; basis and coxa normal.

Ambulatory pereiopods robust. Third pereiopod exceeds carpocerite by dactyl, propod, and distal three-quarters of carpus; dactyl compressed, about 0.19 of propod length, unguis distinct, about 0.4 of dorsal length of corpus, corpus about 2.5 times longer than proximal depth, with one distolateral sensory seta, ventral margin feebly concave, with acute distal accessory tooth, distal accessory tooth reaching at about proximal 0.4 of unguis; propod about 0.64 of carapace length, 10.5 times longer than maximum wide, slightly tapered distally, with one pair of slender simple distoventral spines, one pair of similar subdistoventral spines, three single spines distributed on ventral margin, one small transverse row of long setae distolaterally and scattered setae on distodorsal and ventral margin; carpus about 0.47 of propod length, 4.2 times longer than distal width, unarmed; merus 0.94 of propod length, 8.85 times longer than wide, uniform, unarmed; ischium 0.42 of propod length, 3.62 times longer than distal width, slightly proximally tapered; basis and coxa without special features. Fourth and fifth pereiopods similar to third, fourth propod subequal, fifth propod 1.1 times third propod length, fifth exceeds carpocerite by dactyl and distal $9 / 10$ propod.

Uropod with protopodite with posterolateral angle short, rounded; exopod 2.5 times longer than central width, lateral border feebly convex, with small acute distal tooth, mobile spine medially lost, diaeresis distinct; endopod subequal to exopod length, 3.3 times longer than wide.

Paratype. Similar to holotype. Rostrum with six dorsal teeth. Telson slender, 1.69 times sixth abdominal somite, 4.1 times proximal width, with four pairs of dorsolateral spines at $0.41,0.58,0.72$ and 0.88 of telson length, right side with one additional spine at 0.95 of telson length, the spines about 0.056 of telson length; lateral margins straight, tapered distally, posterior margin 0.4 of proximal width, with three pairs of spines, lateral spines similar to dorsolatal spines, intermediate spines long and robust, about 0.12 of telson length, submedian spines slender, non-setae, about 0.36 of intermediate spine length. Uropod exceeding telson tip.

\section{Measurements (mm)}

Holotype. Carapace length, 7.3; carapace and rostrum, 10.3; total animal length (proximally), 29.5; left (minor) second pereiopod chela, 7.4; ovum length, 0.73.

Paratype. Carapace length, 6.8; total animal length (proximally), 28.6; left (major) second pereiopod chela, 10.4; right (minor) second pereiopod chela, 6.1. 


\section{Systematic position}

In its general morphology, especially the raised proximal dorsal rostral carina, Periclimenes forgesi $\mathrm{sp}$. n. shows a close resemblance to P. vaubani Bruce, 1990a. Periclimenes forgesi may be distinguished from that species easily by the four pairs of dorsolateral telson spines, and also the following features: (1) rostrum with deeper lamina; (2) carapace without epigastric tubercle; (3) hepatic spine on carapace subequal to antennal spine; (4) ambulatory propods lacking transverse rows of setae ventrally except the small row distoventrally; (5) scaphocerite with distal lamella distinctly exceeding distolateral tooth; and (6) first pereiopod with carpus shorter than chela. Periclimenes forgesi differs from the other deepwater Periclimenes species with four pairs of dorsolateral telson spines by the short and slender rostrum with a distinct proximal elevated dorsal margin over orbital region, ventral margin straight, with one tooth, cornea well developed, about 0.16 of the postorbital margin carapace length, hepatic not noticably larger than antennal spine, ambulatory propods lacking transverse rows of setae on ventral margin.

\section{Etymology}

The specific name is given in honour of the specimen collector, Dr Bertrand Richer de Forges.

\section{Remarks}

The small hepatic spines on both sides of the holotype are broken basally, appearing as if articulated on the carapace, making the species appear similar to Allopontonia iaini Bruce, 1972. But, the armature of ambulatory pereiopods is not as in Allopontonia iaini, in which the ventral border of ambulatory propods are strongly spinulate, the ventral border of dactyl is denticulate, not armed with only one accessory tooth. In addition, Allopontonia is an echinoid-associated genus in shallow water.

\section{Periclimenes foveolatus Bruce, 1981}

Periclimenes foveolatus Bruce 1981a, p 196-201, Figures 6-9, 17a, b, 18b, e; Bruce 1991a, p 312, Figures 8, 72; Chace and Bruce 1993, p 111; Li 2000, p 182, Figure 22.

\section{Material examined}

Philippines: MUSORSTOM 3, stn CP91, $14^{\circ} 00^{\prime} \mathrm{N}, 120^{\circ} 18^{\prime} \mathrm{E}, 190-203 \mathrm{~m}, 31$ May 1985, 1ðึ (MNHN-Na 14892).

\section{Remarks}

Previously known only from the type material. The single specimen has a rostral dentition of $9 / 4$ and lacks any trace of an epigastric spine or tubercle. The cornea is moderately large. The minor second pereiopod only is preserved, the palm of the chela is feebly, minutely tuberculate ventrally. The third pereiopod has the dactyl with a small, slender accessory tooth and the telson has two pairs of medium-sized dorsal spines. 


\section{Distribution}

Type locality: SW of Manila Bay, Philippines, 191-188 m. Also recorded from Loyalty Islands.

\section{Periclimenes hertwigi Balss, 1913}

(Figure 21)

Periclimenes hertwigi Balss 1913, p 235; Bruce 1990a, p 151, Figures 1-2, 39c; Chace and Bruce 1993, p 113; Li 2000, p 189, Figure 239; Davie 2002, p 327.

Periclimenes Hertwigi: Balss 1914, p 49-51, Figures 28-30.

Periclimenes (Ancylocaris) gracilirostris Kubo 1940b, p 41-44, Figures 8-10.

Periclimenes (Periclimenes) hertwigi: Holthuis 1952a, p 43-47, Figures 11, 12.

\section{Material examined}

Philippines: MUSORSTOM 3, (i) stn CP90, $14^{\circ} 00^{\prime} \mathrm{N}, 120^{\circ} 19^{\prime} \mathrm{E}, 195 \mathrm{~m}, 31$ May 1985, 1 ovig. @ (MNHN-Na 14898). Indonesia: KARUBAR, (ii) Tanimbar Islands, stn CP45, $7^{\circ} 54^{\prime} \mathrm{S}, 132^{\circ} 47^{\prime} \mathrm{E}, 302-305 \mathrm{~m}, 29$ October 1991, $1 \delta^{\hat{\sigma}}$ (MNHN-Na 14895); (iii) Kai Islands, stn CP27, 5 $33^{\prime} \mathrm{S}, 132^{\circ} 51^{\prime} \mathrm{E}, 304-314 \mathrm{~m}, 26$ October $1991,1{ }^{\hat{\jmath}}$ (MNHN-Na 15879). Solomon Islands: SALOMON 1, (iv) stn CP1792, $9^{\circ} 15.4^{\prime} \mathrm{S}, 160^{\circ} 08.9^{\prime} \mathrm{E}, 477-$ $505 \mathrm{~m}, 30$ September 2001, 1o (MNHN-Na 15538); (v) stn CP1831, 10 12.1'S, $161^{\circ} 19.2^{\prime} \mathrm{E}, 135-325 \mathrm{~m}, 5$ October 2001,1 ovig. ㅇ (MNHN-Na 15537). SALOMON 2, (vi) Rendova, stn CP2284, $8^{\circ} 38.4^{\prime}$ 'S, $157^{\circ} 21.5^{\prime} \mathrm{E}, 195-197 \mathrm{~m}$, November 2004, 1 ovig. 우 (MNHN-Na 15947); (vii) northwest Isabel, stn CP2210, $7^{\circ} 34.2^{\prime} \mathrm{S}, 157^{\circ} 41.8^{\prime} \mathrm{E}, 240$ $305 \mathrm{~m}$, November 2004, 1 ovig. @ (MNHN-Na 15948); (viii) northwest Isabel, stn CP2199, $7^{\circ} 43.1^{\prime} \mathrm{S}, 158^{\circ} 29.6^{\prime} \mathrm{E}, 296-304 \mathrm{~m}$, November 2004, 2 ovig. 우 (MNHN-Na 15957); (ix) Vella Gulf, stn CP2260, 8 $03.5^{\prime} \mathrm{S}, 156^{\circ} 54.5^{\prime} \mathrm{E}, 399-427 \mathrm{~m}$, November 2004,

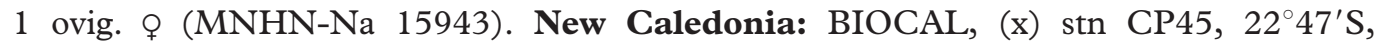
$167^{\circ} 15^{\prime} \mathrm{E}, \quad 430-465 \mathrm{~m}, 30$ August 1985, 1), 1 ovig. \& (MNHN-Na 14901). MUSORSTOM 4, (xi) stn 156, $18^{\circ} 54.0^{\prime} \mathrm{S}, 163^{\circ} 18.8^{\prime} \mathrm{E}, 525 \mathrm{~m}, 15$ September 1985,1 ovig. ㅇ (MNHN-Na 14904); (xii) stn 169, 18 $54.3^{\prime} \mathrm{S}, 163^{\circ} 11.2^{\prime} \mathrm{E}, 390 \mathrm{~m}, 17$ September 1985, 1 juvenile $\widehat{\jmath}$ (MNHN-Na 14903); (xiii) stn $194,18^{\circ} 52.8^{\prime} \mathrm{S}, 163^{\circ} 21.7^{\prime} \mathrm{E}, 545 \mathrm{~m}, 19$ September 1985, 1수 1 ovig. ㅇ (MNHN-Na 14899); (xiv) stn $221,22^{\circ} 58.6^{\prime} \mathrm{S}, 167^{\circ} 36.8^{\prime} \mathrm{E}$,

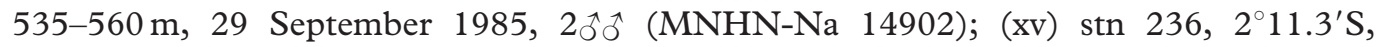
$163^{\circ} 15.0^{\prime} \mathrm{E}, 495-550 \mathrm{~m}, 2$ October 1985, 1 \% (MNHN-Na 14900). HALIPRO 1, (xvi) stn $\mathrm{CP} 866,21^{\circ} 26.91^{\prime} \mathrm{S}, 166^{\circ} 17.23^{\prime} \mathrm{E}, 550-600 \mathrm{~m}, 22$ March 1993, $1{ }^{\wedge}$ (MNHN-Na 14897). BATHUS 2, (xvii) stn CP770, 22 09.56'S, $166^{\circ} 04.09^{\prime} \mathrm{E}, 400-402 \mathrm{~m}, 18$ May 1993, 1

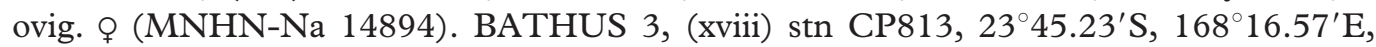
410-415 m, 28 November 1993, 1 ovig. o (MNHN-Na 14896). NORFOLK 1, (xix) Norfolk Ridge, stn CP1708, 23 $43^{\prime}$ S, $168^{\circ} 16^{\prime} \mathrm{E}$, 381-384 m, Banc Jumeau-est, 25 June 2001, 1 ๙ै (MNHN-Na 15866).

\section{Parasites}

Specimen (xv) had a branchial parasite, Bopyrinina paucimaculata Markham [Isopoda: Bopyridae]. 


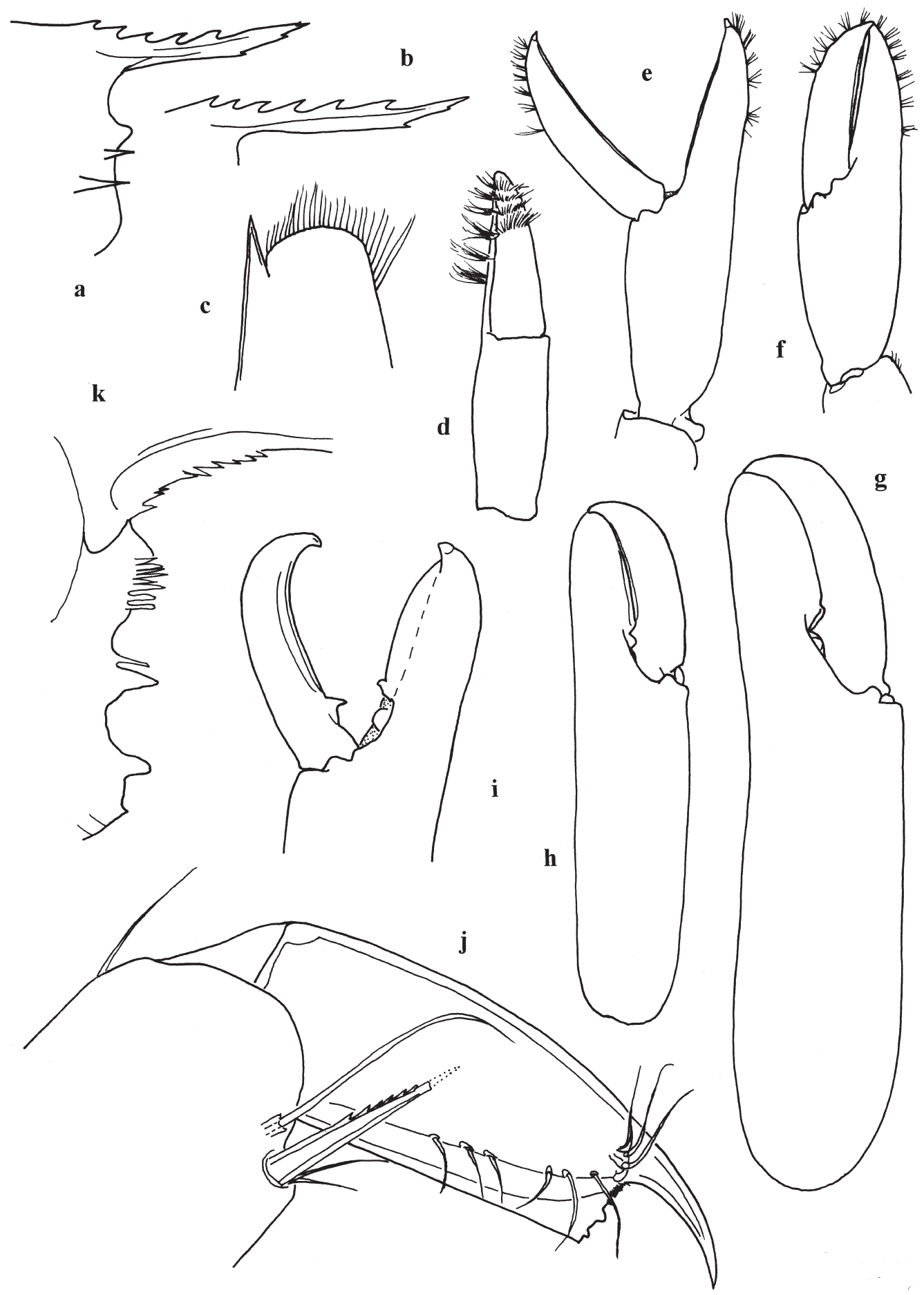

Figure 21. Periclimenes hertwigi Balss, 1913. ( $\mathrm{a}, \mathrm{h}$ ) Ovigerous female (MNHN-Na 14899); (b, e, g, i) male (MNHN-Na 14899); (c, d, f) ovigerous female (MNHN-Na 14896); j, k, male (MNHN-Na 14901). (a) Anterior carapace; (b) rostrum; (c) distal antennal scale; (d-f) first pereiopod, chela, lateral view; $(\mathrm{g}, \mathrm{h}$ ) second pereiopod, chela; (i) same, fingers; (j) third pereiopod, distal propod and dactyl; (k) same, distoventral angle of corpus. 
Remarks

Not previously reported from the Philippines or Indonesia. The Philippines specimen (i) has the rostrum with three ventral rostral teeth.

\section{Distribution}

Type locality: Sagami Bay, Japan, $120 \mathrm{~m}$. Now known from East China Sea, Japan, Philippines, Indonesia, Australia (Queensland), and New Caledonia.

Periclimenes imperator Bruce, 1967

Periclimenes imperator Bruce 1967a, p 53-62, Figures 23-25; Bruce 1991b, p 237; Bruce 1996, p 234; Li 2000, p 192, Figure 243; Davie 2002, p 327; Li and Liu 2004, p 95, Figure 6.

\section{Material examined}

Madagascar: (i) Pracel Bank, west coast, 55 m, sand, trawl, coll. A. Crosnier, June 1959, 1 ๙ै (MNHN-Na 14909); (ii) Nosy Be, stn 10, 26 m, coll. P. Laboute, 9 September 1992, phot. CD03, 1 今ิ, 1 ovig. @ (MNHN-Na 14939). New Caledonia: (iii) scuba stn 535, coll. J.-L. Menou, no date record, 1ô, 1ọ (MNHN-Na 14907); (iv) MONTROUZIER, Koumac: Ilot Tangdion, dredge, coll. B. Richer de Forges, 8 October 1993, 1 ovig. $q$ (MNHN-Na 14908).

Hosts

(ii) Melibe sp.; (iii) Thelonota ananas (Jaeger) [Holothuroidea, Echinoderma].v

\section{Remarks}

First reported from Nouméa (New Caledonia) by Bruce (1967b) and subsequently also in New Caledonia from Nouméa, Île Ouen, Baie du Prony, Île des Pins, and Lagoon Nord Ouest by Bruce (1991b). Previously reported from Madagascar, from Baie d'Ambaro (Bruce 1977c) and also from Mitsio Island, by Bruce (1978a). The specimen from Pracel Bank at the depth of $55 \mathrm{~m}$ represents a new bathymetric record for this species, previously known only to $30 \mathrm{~m}$ (Bruce 1991b). Unfortunately this identification cannot be considered absolutely certain as the specimen lacks a rostrum.

\section{Distribution}

Type locality: Chumbe Island, Zanzibar. Also known from Egypt, Israel, Jordan, Kenya, Zanzibar, Mozambique, Comoro Islands, Madagascar, Seychelles, Japan, Indonesia, Australia (Western Australia, Queensland), Caroline Islands, New Caledonia, and Hawaii. 
Periclimenes incertus Borradaile, 1915

Periclimenes (Cristiger) incertus Borradaile 1915, p 210; Borradaile 1917, p 364, Plate 53, Figure 7.

Periclimenes (Periclimenes) impar Kemp 1922, p 147-149, Figures 16, 17, Plate 3, Figure 1. Periclimenes (Periclimenes) incertus: Holthuis 1959, p 193-194.

Periclimenes incertus: Chace and Bruce 1993, p 114; Bruce 1996, p 234; Li 2000, p 193, Figure 244; Davie 2002, p 327.

\section{Material examined}

Madagascar: (i) northwest coast, S. W. Îles Mitsio, $30 \mathrm{~m}$, sand, trawl, coll. A. Crosnier, February 1960, 3 ovig. 우 (MNHN-Na 14910); (ii) northwest coast, Tany Kely, Nosy Be' $20 \mathrm{~m}$, on sponge, coll. P. Laboute, 19 July 1970, 41 spms (8 ovig. oㅇ) (MNHN-Na 14911). Solomon Islands: (iii) SALOMON 1, stn CP $1810,9^{\circ} 47.7^{\prime} \mathrm{S}, 160^{\circ} 50.5^{\prime} \mathrm{E}, 53 \mathrm{~m}, 3$ October 2001, 1 ovig. \& (MNHN-Na 15586). New Caledonia: (iv) lagoon, Îlot Maitre, scuba, $25 \mathrm{~m}$, with sponge, coll. C. Vadon, 5 September 1978, 3oᄋ (2 ovig.) (MNHN-Na

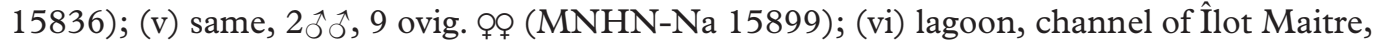
scuba, $25 \mathrm{~m}$, with sponge, coll. C. Vadon, 5 September 1978, 1ิ^, 8 ovig. o̊ (MNHN-Na 15861); (vii) lagoon, Five Mile Channel, scuba, 15-20 m, associated with alcyonarian

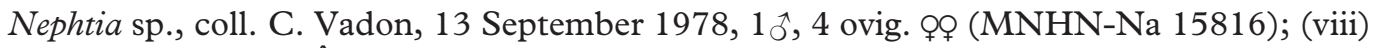
lagoon, channel of Îlot Maitre, stn 21, scuba, $25 \mathrm{~m}$, with sponge, coll. C. Vadon, 19

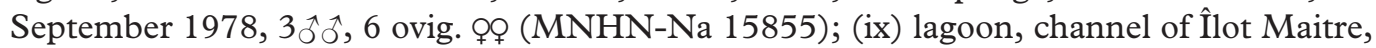
scuba, $25 \mathrm{~m}$, with sponge, coll. C. Vadon, 19 September 1978, 1 ovig. \& (MNHN-Na

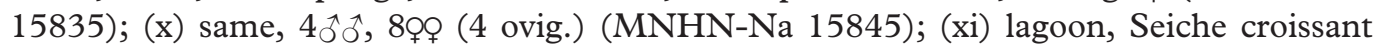
Reef, scuba, 9 m, with coral, coll. C. Vadon, 29 September 1978, 10, 1 ovig. \& (MNHNNa 15900); (xii) lagoon, coll. C. Vadon, 4 October 1978, 6 ovig. @o (MNHN-Na 15844); (xiii) lagoon, southwest, $22^{\circ} 19.41^{\prime} \mathrm{S}, 166^{\circ} 20.89^{\prime} \mathrm{E}, 20 \mathrm{~m}$, scuba, with sponge, coll. I. Takeuchi, 9 November 1995, 1o, 1 spm (abdomen lost) (MNHN-Na 15907); (xiv) Îlot Maitre, $22^{\circ} 19.35^{\prime} \mathrm{S}, 166^{\circ} 25.85^{\prime} \mathrm{E}, 20 \mathrm{~m}$, scuba, with sponge, coll. I. Takeuchi, 10

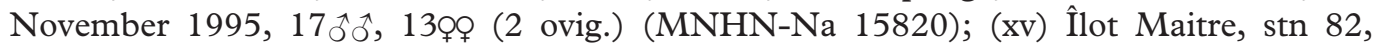
$22^{\circ} 19.61^{\prime} \mathrm{S}, 166^{\circ} 24.07^{\prime} \mathrm{E}, 10 \mathrm{~m}$, coll. I. Takeuchi, 14 November $1995,33 \mathrm{spms}$ (13 ovig. ○ᄋ) (MNHN-Na 15877); (xvi) lagoon (Seiche Croissant), seagrass, small trawl, coll. Richer

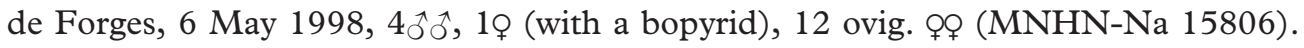

\section{Hosts}

(ii) Rhizochalina sp.; (viii) ?Siphonochalina sp.; (xii) Clathrya astroderma [Porifera]. (vii) Nephtia sp. [Alcyonaria].

\section{Remarks}

Previously reported from Madagascar, from Baie d'Ambaro (Bruce 1977c) and from Tany Kely (Bruce 1978a). The Solomon Islands record represents the greatest depth from which this species has so far been reported. The Tany Kely specimens are largely juveniles: the second pereiopods, in those specimens in which they are still both attached, are distinctly unequal. The Ampombilava specimen lacks both second pereiopods but can be safely identified by the characteristic ambulatory dactyl. The association with Rhizochalina 
represents a new host record. Periclimenes incertus has been frequently noted as an associate of sponges. Previously reported hosts include species of the genera Acarnus, Clathria, Desmopsamma, Dysidea, Oceanapta, Petrosia, Siphonochalina, and Spirastrella (Bruce 1976b); Arenochalina and Leucetta (Bruce 1983d); and Callyspongia (Bruce 1988c).

\section{Distribution}

Type locality: South Nilandu Atoll, Maldives. Also known from Yemen, Kenya, Zanzibar, Tanzania, Madagascar, Sri Lanka, Andaman Islands, Singapore, Philippines, Indonesia, Australia (Western Australia, Northern Territory, Queensland), and New Caledonia.

\section{Periclimenes involens Bruce, 1996}

(Figure 22)

Periclimenes involens Bruce 1996, p 234, Figures 13, 28h; Li 2000, p 198, Figure 251.

\section{Material examined}

La Réunion: $\mathrm{MD} 32$, stn $\mathrm{CP} 55,21^{\circ} 05.3^{\prime} \mathrm{S}, 55^{\circ} 12.5^{\prime} \mathrm{E}, 97-110 \mathrm{~m}, 22$ August 1982, 1 ovig. ㅇ (MNHN-Na 14912).

\section{Remarks}

Previously known only from the type specimens from the Philippines. The present specimen agrees closely with the original description and is in good condition with intact rostrum and both second pereiopods. The specimen has a carapace length of $2.3 \mathrm{~mm}$, the rostrum reaching the end of the antennular peduncle, with a dentition of $1+7 / 2$, the first tooth situated slightly posterior to the level of the orbital margin. The specimen lacks the elevated posterior dorsal rostral carina found in $P$. vaubani and the ventral teeth are distinctly larger. The ventral border of the rostrum is straight, and not convex as in $P$. richeri. The second pereiopods are similar, unequal, both dactyls with a dorsal flange, the major carpus is about 0.3 of the palm length and the minor about 0.5 . This new record indicates a large increase in the range of this small species. The only previous record was from a similar depth, 92-97 $\mathrm{m}$.

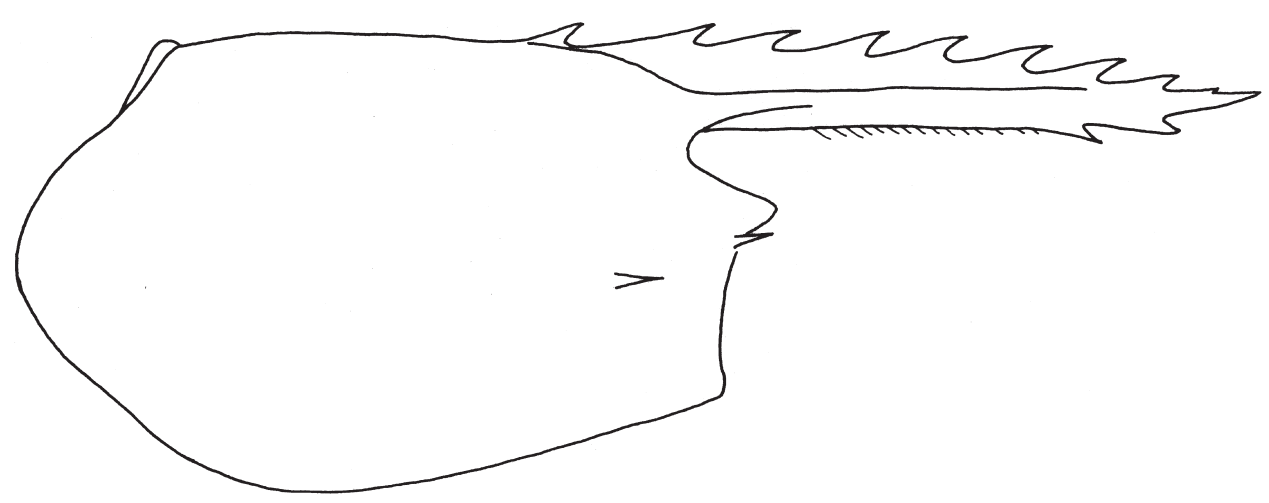

Figure 22. Periclimenes involens Bruce, 1996, ovigerous female (MNHN-Na 14912), carapace. 


\section{Distribution}

Type locality: $12^{\circ} 31^{\prime} \mathrm{N}, 120^{\circ} 39^{\prime} \mathrm{E}$, off Mindoro, Philippines. Now also known from La Réunion.

Periclimenes kempi Bruce, 1969

Periclimenes kempi Bruce 1969b, p 260; Bruce 1981b, p 80, Figure 2; Fransen 1994, p 125; Bruce and Coombes 1995, p 131; De Grave 2000, p 136; Li 2000, p 200, Figure 256.

\section{Material examined}

New Caledonia: lagoon, Five Mile Channel, scuba, 15-20 m, associated with alcyonarian Nephthya sp., coll. C. Vadon, 13 September 1978, 20ิ ô, 1ㅇ (MNHN-Na 15823).

Host

Nephthya sp. [Alcyonacea].

\section{Distribution}

Type locality: Red Sea coast of Egypt, $1 \mathrm{~m}$. Known also from Kenya, Zanzibar, Seychelles, Andaman Islands, Singapore, Papua New Guinea, Australia (Cobourg Peninsula, Great Barrier Reef), New Caledonia, and Fiji.

Periclimenes laccadivensis (Alcock and Anderson, 1884)

Palaemonella laccadiversis Alcock and Anderson 1894, p 157.

Periclimenes laccadivensis: Kemp 1922, p 152, Figure 19; Bruce 1979a, p 225; Bruce 1991a, p 301, Figure 1; Bruce 1992, p 69, Figure 20; Li 2000, p 202, Figure 259.

\section{Material examined}

New Caledonia: (i) LITHIST, stn DW05, 2338.2'S, $167^{\circ} 42.9^{\prime} \mathrm{E}, 433-500 \mathrm{~m}$, Stylaster Bank, 10 August 1999, 1 ovig. o (MNHN-Na 15881); (ii) NORFOLK 1, Norfolk Ridge,

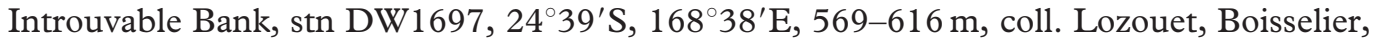
Richer-IRD, 24 June 2001, 1 ovig. \& (MNHN-Na 15930).

\section{Remarks}

Previously recorded from New Caledonia by Bruce (1991a).

\section{Distribution}

Type locality: Laccadive Sea, 770-1353 m. Known also from western Indian Ocean, South China Sea, New Caledonia, and off Australia (Tasmania). 
Periclimenes lanipes Kemp, 1922

(Figure 23)

Periclimenes (Periclimenes) lanipes Kemp 1922, p 156-158, Plate 4, Figure 4.

Periclimenes lanipes: Bruce 1991b, p 237; Chace and Bruce 1993, p 116; Li 2000, p 203, Figure 261; Davie 2002, p 329.

Material examined

Philippines: (i) Maribago, Mactan Island, Cebu, washings, coll. P. Bouchet, 9 June 1985,

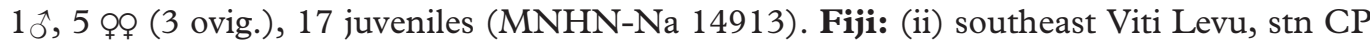
$1358,17^{\circ} 48.5^{\prime} \mathrm{S}, 178^{\circ} 46.7^{\prime} \mathrm{E}, 80-120 \mathrm{~m}$, coll. P. Bouchet, B. Richer de Forges, 13 August 1998, 1 ๙ (MNHN-Na 15587).

Hosts

(i) Euryale aspera Lamarck, 1816 and Astrboa nuda (Lyman, 1874), det. A. Gilles [Ophiuroidea, Echinoderma].
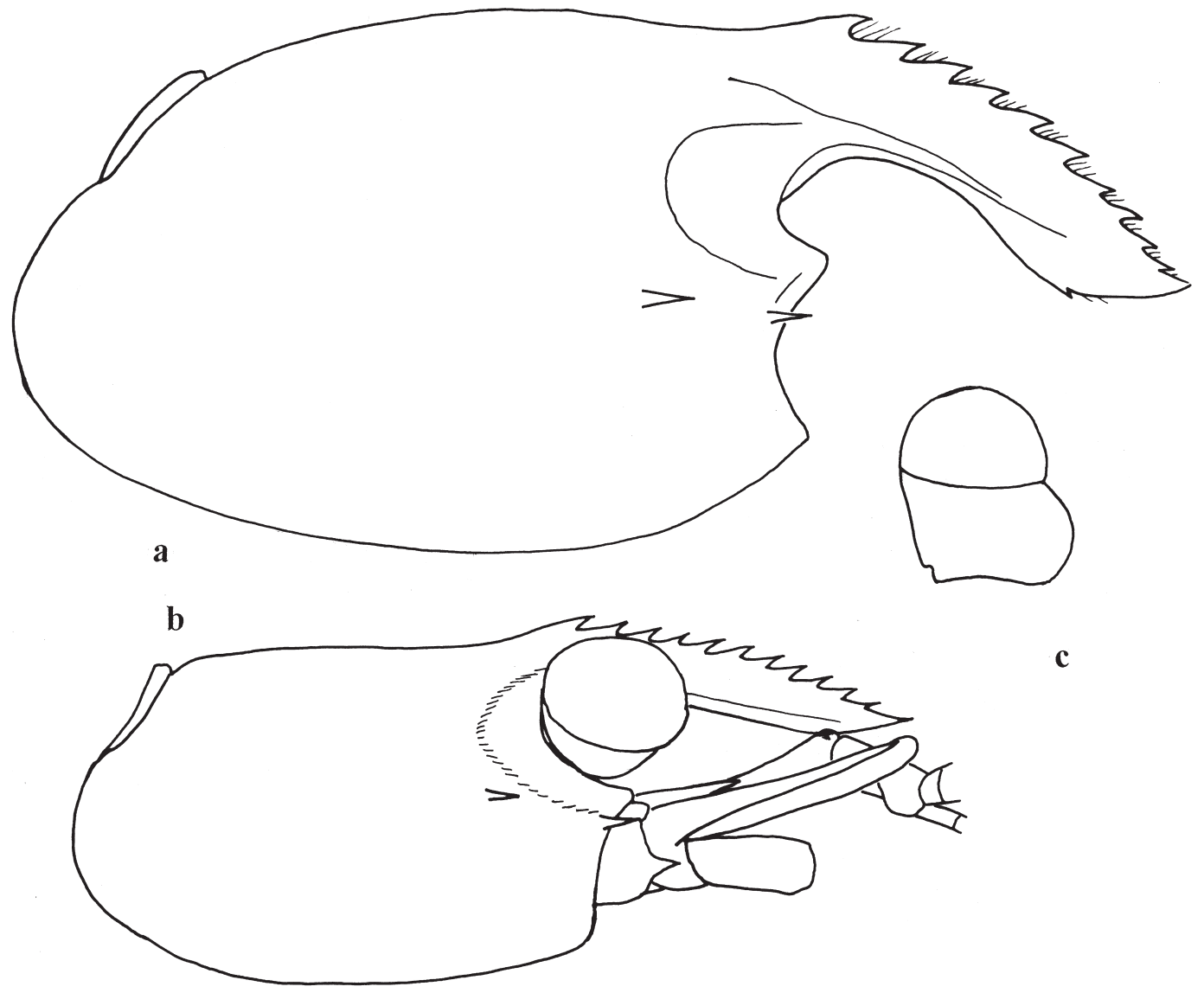

c

Figure 23. Periclimenes lanipes Kemp, 1922. a, c, ovigerous female; (b) male (MNHN-Na 14913). (a, b) Carapace; (c) eye. 
Remarks

Previously reported from Jolo Island and Siasi, Sulu Islands from Philippines (Chace and Bruce 1993). Not previously reported from Fiji.

\section{Distribution}

Type locality: $12^{\circ} 48^{\prime} \mathrm{N}, 98^{\circ} 16^{\prime} 10^{\prime \prime} \mathrm{E}$, Mergui Islands, Burma, $44 \mathrm{~m}$. Also known from Somalia, Kenya, Zanzibar, Mozambique, Madagascar, Singapore, South China Sea, Philippines, Australia (Queensland), New Caledonia, and Fiji.

Periclimenes latipollex Kemp, 1922

Periclimenes (Periclimenes) latipollex Kemp 1922, p 150, Figure 18, Plate 4, Figure 3; Holthuis 1952a, p 47-48, Figures 13, 14.

Periclimenes latipollex: Bruce 1971a, p 8; Bruce 1981a, p 195, Figure 3; Bruce 1991a, p 309, Figure 6; Li 2000, p 204, Figure 262.

\section{Material examined}

New Caledonia: NORFOLK 2, Norfolk Ridge, Jumeau Est Bank, stn DW 2108, 234' S, $168^{\circ} 17^{\prime} \mathrm{W}, 403-440 \mathrm{~m}, 31$ October 2003, 1 ovig. 우 (MNHN-Na 15937).

Remarks

The dactyl of ambulatory pereiopods with accessory spine is minute, as shown by Bruce (1991a, p 309, Figure 6f), but the rostrum is very slender, rod-like as shown by Kemp (1922) and Holthuis (1952a), with rostral formula 2+6/2. Previously recorded from New Caledonia by Bruce (1991a). The present record extends its bathymetric range from 73$304 \mathrm{~m}$ to $440 \mathrm{~m}$.

\section{Distribution}

Type locality: Mergui Archipelago. Also known from Somalia, Kenya, Philippines, Indonesia, and New Caledonia.

Periclimenes lepidus Bruce, 1978

Periclimenes lepidus Bruce 1978a, p 244-252, Figures 20-24; Li 2000, p 205, Figure 264.

Material examined

Comoro Islands: (i) BENTHEDI, north Pamanzi Island, stn $32 \mathrm{R}, 12^{\circ} 45.1^{\prime} \mathrm{S}, 45^{\circ} 17.9^{\prime} \mathrm{E}$, 15-20 m, slope with corals going to a sandy area with Heterocongridae, 1 ovig. \& (MNHNNa 15942). Madagascar: (ii) northwest coast, near Nosy Be, Entrée Bank of SE slope, 40 m, coll. P. Laboute, 10 September 1970, 1 ô, 6ọ (3 ovig.) (MNHN-Na 14915). New Caledonia: (iii) MONTROUZIER, Touho Channel, $35 \mathrm{~m}$, from antipatharians, coll. B. Richer de Forges, 31 August 1993, 9 spms (7 ovig. ơ) (MNHN-Na 14914).

\section{Remarks}

Not previously recorded from Comoro Islands and New Caledonia. Previously recorded from Madagascar, from Nosy Be (Bruce 1978a), so the Madagascar specimens are topotypic. 


\section{Distribution}

Type locality: Nosy Be, Madagascar, $40 \mathrm{~m}$. Also known from Kenya, Seychelles, and Maldives.

Periclimenes loyautensis sp. nov.

(Figure 24)

\section{Material examined}

Loyalty Islands: MUSORSTOM 6, stn CP464, $21^{\circ} 02.30^{\prime} \mathrm{S}, 167^{\circ} 31.60^{\prime} \mathrm{E}, 430 \mathrm{~m}$, coll. B. Richer de Forges, 21 February 1989, 1 ovig. ㅇ holotype (MNHN-Na 14947).

\section{Description}

A medium size, robust pontoniine shrimp of subcylindrical body form; lacking right second (major ?), fifth and left third pereiopods, left second (minor ?) pereiopod detached.

Carapace smooth, glabrous. Rostrum well developed, moderately deep, compressed, extending well beyond antennular peduncle, about 0.66 of carapace length, not reaching distal scaphocerite, anteroventrad except the anterad tip; dorsal carina deep, with seven

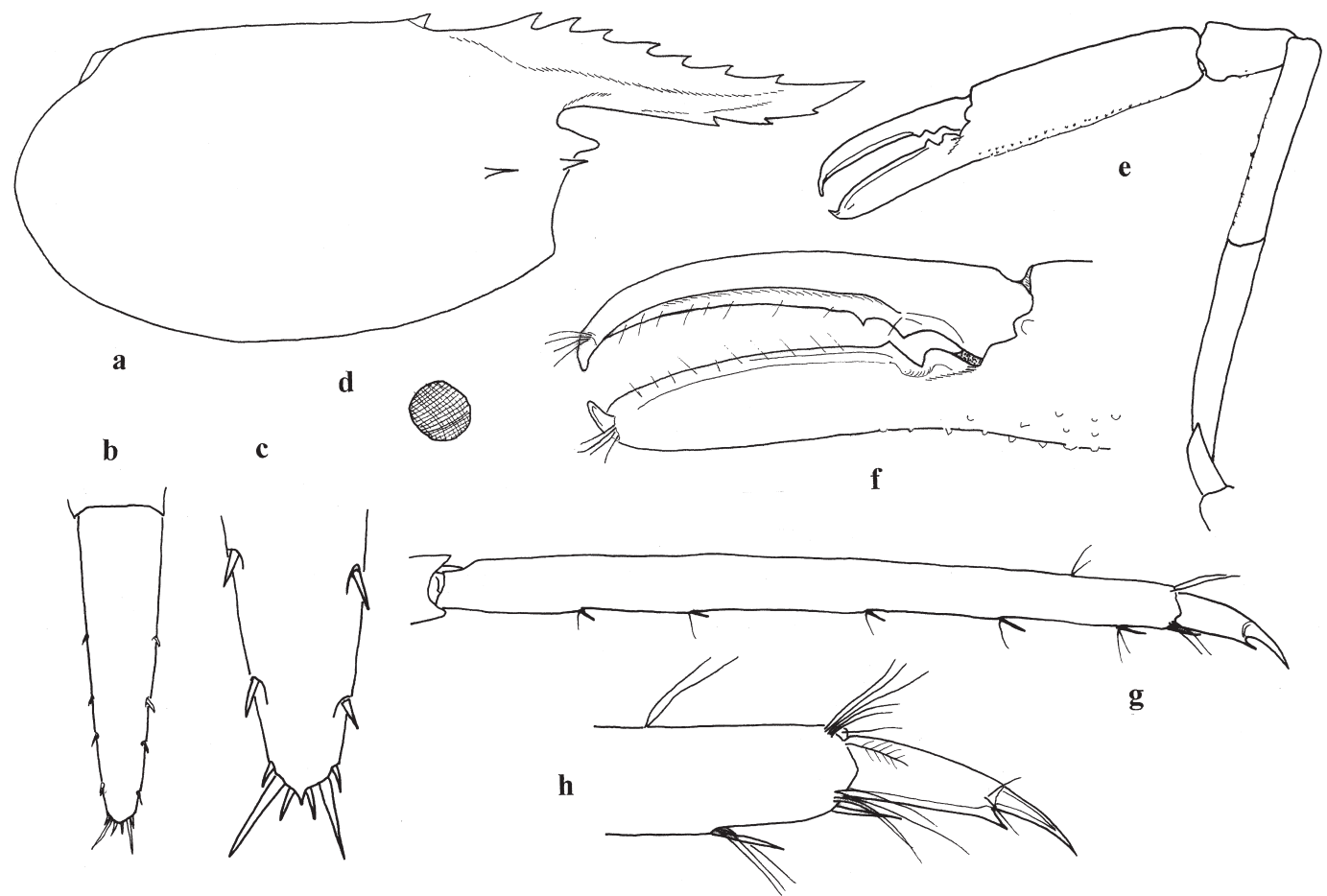

Figure 24. Periclimenes loyautensis, new species, holotype ovigerous female (MNHN-Na 14947). (a) Carapace; (b) telson; (c) same, distal part; (d) eye, distal view; (e) minor second pereiopod; (f) same, fingers; (g) third pereiopod, propod and dactyl; (h) same, distal propod and dactyl. 
subequal acute teeth along all length, proximal three more closely grouped than distal teeth, first tooth situated just posterior to posterior orbital margin; lateral carinae feebly developed, slightly upcurved distally and extending posteriorly on carapace posterodorsally; ventral carina feebly developed, with three low acute teeth on distal half margin, smaller than dorsal teeth; interdental spaces and proximal ventral carina feebly setose. Supraorbital spine absent; epigastric spine situated at anterior 0.3 of the carapace length, with basal suture; orbit feebly developed, inferior orbital angle strongly produced, round; antennal spine small slender marginal, distinct below the inferior orbital angle, not exceeding inferior orbital angle; hepatic spine larger than antennal one, slender, very slightly lower than, almost at same level of antennal spine, below between the epigastric spine and the first dorsal rostral tooth and closer to first dorsal rostral spine in lateral view; anterolateral angle of carapace not produced, bluntly rounded.

Abdominal segments smooth, glabrous; third abdominal segment not produced, noncarinate; pleura of first three segments broadly rounded, fourth and fifth posteriorly produced rounded, sixth segment about 1.8 times length of fifth, subcylindrical, about 1.73 times longer than deep, subuniform, posterolateral angle acute, posteroventral angle rounded. Telson about 1.53 times sixth segment length, about 3.7 times longer than anterior width, lateral margins with posterior two-thirds straight, convergent, posterior margin about 0.32 of anterior margin width, rounded, without posterior median point; dorsal surface with four pairs of small but well-developed dorsolateral spines at $0.4,0.6$, 0.75 , and 0.9 of telson length, spines about 0.044 of telson length; posterior margin with three pairs of spines, lateral spines short, similar to dorsolateral spines, intermediate spines long, robust, about 0.12 of telson length, submedian spines slender, about 0.41 of intermediate spine length.

Eye small, with globular cornea, corneal diameter 0.13 of posterior orbital carapace length, without accessory pigment spot; stalk subequal to corneal diameter, subequal to corneal width, feebly compressed.

Antennular peduncle overreaching distal ventral rostral tooth; proximal segment about 2.0 times longer than central width, with slender acute stylocerite laterally, reaching to about 0.7 of segment length, anterolateral margin feebly produced, setose, with long slender acute lateral tooth reaching near to the end of dorsal margin of intermediate segment; statocyst small; medial margin setose, with ventromedial tooth at about 0.5 of length; intermediate segment with dorsal length about 0.3 of proximal segment length, 1.1 of width, lateral margin expanded, setose; distal segment about 0.43 times proximal segment length, slender, about 2.0 times longer than distal width; upper flagellum biramous, with 10 proximal segments of rami fused, shorter free ramus with five segments, length about 0.5 of fused portion, total length about 0.54 of carapace length, with about 23 groups of aesthetascs; longer ramus, slender, filiform, distal segments lost; lower flagellum slender, filiform, about 0.87 times carapace length.

Antennal basicerite robust, with acute distolateral tooth; carpocerite about 0.49 of length of lateral margin of scaphocerite, about 3.2 times longer than width, subcylindrical, reaching about 0.41 of total length of scaphocerite; flagellum well developed, slender, about 2.2 times postorbital carapace length; scaphocerite well developed, distinctly exceeding tip of rostrum, broad, about 2.5 times longer than wide, greatest width at about 0.4 of length, distal margin bluntly rounded, distinctly exceeding distolateral tooth, lateral margin nearly straight, with strong acute distolateral tooth.

Epistome unarmed. Fourth thoracic sternite without slender median process; posterior sternites unarmed. 
Mouthparts mainly undissected. Mandible without palp; incisor process distally with three (right) or four (left) stout acute teeth, central teeth smaller than outer teeth. Third maxilliped with slender endopod, extending distally to three-quarters length of carpocerite, ischiomerus and basis incompletely fused, basal portion medially expanded, convex, combined segment compressed, setose medially; intermediate segment about 0.43 of combined proximal segment length, with several groups of long finely serrulate spiniform setae medially; terminal segment about 0.33 of combined proximal segment length, distally tapering, with seven transverse groups of spiniform setae ventromedially, with long distal spiniform setae; exopod with slender flagellum extending to the distal end of ischiomerus, with eight to nine plumose setae distally; arthrobranch distinct.

First pereiopods moderately slender, exceeding tip of rostrum by length of chela; chela with palm subcylindrical, slightly compressed, about 2.33 times longer than maximal depth, at about proximal 0.3 of length with several tranverse rows of short cleaning setae proximoventrally; fingers 0.83 of palm length, slender, tapering, cutting edges sharp, entire, tips hooked, base slightly expanded, surrounded by palisade of long setae medially and laterally at about $0.3,0.7$ and subterminally of fingers; carpus about 1.22 of chela length, 5.4 times longer than distal width, subuniform, with seven to eight serrulate cleaning subdistal setae ventrally; merus about 1.4 times chela length, 7.0 times longer than distal width; ichium 0.78 of chela length, 4.5 times longer than distal width, not strongly carinate distoventrally, obliquely articulated with basis.

Left (minor) second pereiopod well developed, exceeding carpocerite by carpus and chela; chela about 0.93 times postorbital carapace length; palm about 4.0 times longer than maximal depth, with very small tubercles; fingers about 0.7 of palm length, with strongly hooked tips, cutting edges entire, sharp, proximal 0.3 of fixed finger cutting edge with two teeth, proximal one larger and round, distal one smaller and acute, proximal 0.4 of dactyl cutting edge with two acute teeth, proximal one larger than distal; dactyl about 5.3 times longer than proximal depth, with feebly developed lateral flange; carpus cup-like, about 0.43 of palm length, 1.87 times distal width, with scattered small tubercles; merus about 0.9 of palm length, subequal to ischium, with tubercles ventrally; basis and coxa normal.

Ambulatory pereiopods slender. Third pereiopod exceeds carpocerite by dactyl, propod, and distal two-thirds of carpus; dactyl compressed, curved, about 0.18 of propod length, unguis distinct, about 0.61 of dorsal length of corpus, 3.7 times longer than proximal width; corpus about 2.5 times longer than proximal depth, dorsal margin feebly convex, non-setate, ventral margin straight, with acute distal accessory tooth, about 0.29 of unguis length, with two distolateral sensory setae; propod about 0.58 of carapace length, 13 times longer than maximum width, subuniform, with slender simple distoventral spine and five single spines distributed along ventral margin, and scattered long simple setae distally; carpus about 0.53 of propod length, 6.1 times longer than distal width, with distodorsal lobe, unarmed; merus subequal to propod length, 9.2 times longer than central width, uniform, unarmed; ischium subequal to carpus length, 0.52 of propod length, 4.9 times longer than distal width, slightly tapered proximally; basis and coxa without special features. Fourth and fifth pereiopods similar to third, fourth propod subequal, fifth propod 1.1 times third propod length; fifth exceeds carpocerite by dactyl and almost all propod.

Pleopods without special features.

Uropod distinctly exceeding distal end of intermediate posterior spine of telson; protopodite with posterolateral angle short, rounded; exopod 2.7 times longer than central width, lateral border distinctly convex, with small acute distal tooth, with large mobile spine 
medially, diaeresis distinct; endopod about 0.97 of exopod length, 3.6 times longer than wide.

Ova small, numerous, more than 400.

\section{Measurements (mm)}

Carapace length, 5.81; carapace and rostrum, 9.86; total body length (approximately), 26.6; second pereiopod chela, 5.46; length of ovum, 0.45 .

\section{Systematic position}

Periclimenes loyautensis is very close to $P$. aleator Bruce, 1991 and other species of " $P$. alcocki species group" which have more than two (usually four) pairs of dorsolateral telson spines, second pereiopods with lateral flange and covered with fine tubercles. It can be distinguished from $P$. aleator by the hepatic spine very slightly below the level of the antennal spine, at almost the same level, also the relatively more slender ambulatory pereiopods and longer uropods which overreach the distal end of intermediate posterior spine of telson. In $P$. aleator, the hepatic spine is distinctly lower than antennal spine, the ambulatory pereiopods are relatively robust, uropods reach to about middle of intermediate posterior spine of telson. Periclimenes loyautensis differs from P. alcocki Kemp, 1992, by the larger cornea, the diameter is 0.13 of carapace length, and larger dorsolateral telson spines, about 0.044 of telson length, and the third pereiopod without transverse rows of setae distally, propod with well-developed spinulation, dactyl with longer and more slender accessory tooth. In latter species, the corneal diameter is about 0.1 or less of carapace length, the dorsolateral telson spines minute, and the posterior telson spines are also much shorter. Periclimenes loyautensis is also similar to P. crosnieri $\mathrm{n}$. sp., the biunguiculate dactyl of ambulatory pereiopods easily distinguish it from that species, in which the ambulatory dactyl is simple.

\section{Etymology}

The specific name is given from its type locality, the Loyalty Islands.

Periclimenes macrophthalmus Fujino and Miyake, 1970

(Figure 25)

Periclimenes (Harpilius) macrophthalmus Fujino and Miyake 1970, p 250, Figures 3-5.

Periclimenes macrophthalmus: Li 2000, p 211, Figure 272.

\section{Material examined}

Fiji: BORDAU 1, stn CP 1445, 350-365 m, 17 ${ }^{\circ} 10^{\prime} \mathrm{S}, 178^{\circ} 42^{\prime} \mathrm{W}, 3$ March 1999, 1 ovig. ㅇ (MNHN-Na 15620).

\section{Remarks}

The single female accords well with the original description, although it is different in the following aspects: the proximal part of rostrum looks deeper than that of the holotype; the first tooth (epigastric spine) of the dorsal rostral series teeth is similar to others in size, not 


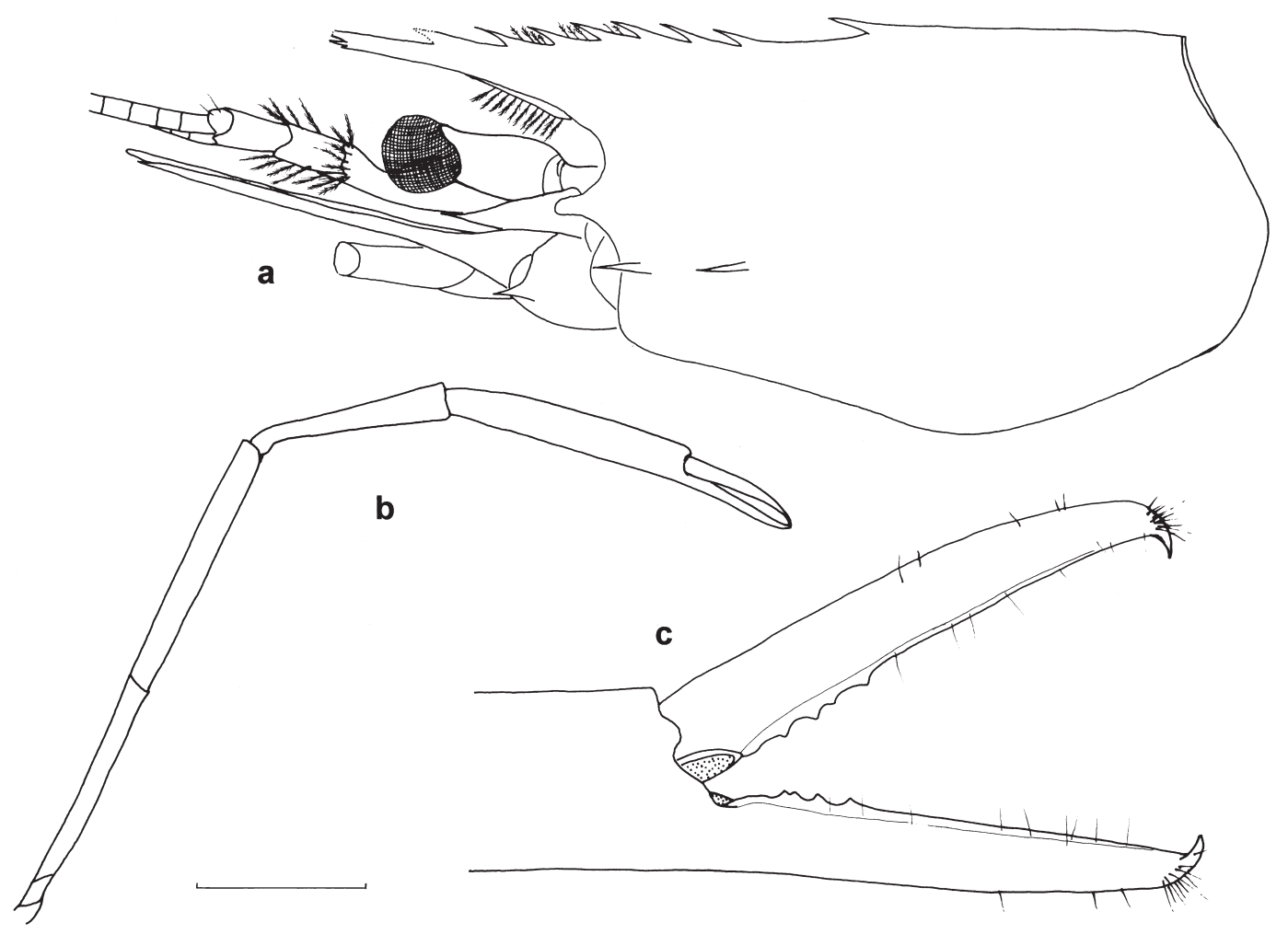

Figure 25. Periclimenes macrophthalmus Fujino and Miyake, 1970, ovigerous female (MNHN-Na 14620). (a) Carapace and anterior appendages; (b) right second pereiopod; (c) fingers of left pereiopod pereiopod. Scale bars: $1.41 \mathrm{~mm}$ (a); $2.24 \mathrm{~mm}$ (b); $0.5 \mathrm{~mm}$ (c).

distinctly stronger than others; the rostrum is armed with at least two ventral teeth, the first minute; the upper flagellum of the antennule is fused for six basal segments. The present specimen is larger than the holotype, with the postorbital carapace length $4.90 \mathrm{~mm}$, telson $3.45 \mathrm{~mm}$. Both second pereiopods and most of the ambulatory pereiopods are lost in the holotype. The present specimen has both the second pereiopods and the ambulatory pereiopods on right side. Second pereiopods are similar and equal, overreaching the end of the scaphocerite by carpus and chela; the chela is subequal to the postorbital carapace length; the palm elongate, about 6.7 times longer than the maximal depth, with very sparse small tubercles; the fingers about 0.46 of the palm length, with strongly hooked tips, proximal 0.3 of the cutting edges of both fingers armed with four to five minute teeth, distal 0.7 of cutting edges entire, sharp; the dactyl about 5.5 times longer than the proximal depth; the carpus distintly swollen distally, about 0.77 of the palm length, 6.07 times the distal width, smooth; the merus unarmed distoventrally, subequal to palm length; ischium 0.95 of palm length; basis and coxa normal. The ambulatory pereiopods are slender. The third pereiopod overreaching the end of the scaphocerite by the dactyl and distal threefifths of the propod; the propod 0.65 of the postorbital carapace length, armed with three 
pairs of long spines and long setae distoventrally; the dactyl 0.17 of the propod length, slender and hooked, the flexor margin concave, unarmed, the unguis distinct; the carpus, merus and ischium $0.62,1.05$ and 0.45 times the palm length, respectively The fourth and fifth pereiopods similar to the third pereiopod. The diameter of egg is 0.45 and length $0.57 \mathrm{~mm}$.

Previously only known from its type locality. The present record extends the range far eastward to Fiji, and the bathymetric range to $350-365 \mathrm{~m}$.

\section{Distribution}

Type locality: East China Sea west of Goto Retto, Kyushu, Japan, 145 m. Now also known from Fiji, 350-365 m.

Periclimenes magnificus Bruce, 1979

Periclimenes magnificus Bruce 1979b, p 195, Figures 1-5; Bruce 1996, p 237; Fransen 1989, p 143, Figures 4b, c, 5e, 6i-m, 7i-p; Li 2000, p 212, Figure 274; Li et al. 2004, p 545, Figure 30; Marin et al. 2004, p 209, Figure 11.

\section{Material examined}

New Caledonia: (i) Vie Bay, scuba, $10 \mathrm{~m}$, coll. P. Laboute, 8 June 1990, 1 ovig. $q$ (MNHN-Na 15841); (ii) Îlot Sainte Marie, cf. antenne radio, scuba, $11 \mathrm{~m}$, coll. P. Laboute, 8 June 1990, 1 ovig. o; (iii) Îlot Maitre, stn $64,22^{\circ} 19.35^{\prime} \mathrm{S}, 166^{\circ} 25.85^{\prime} \mathrm{W}$, $21 \mathrm{~m}$, coll. Alan Myers, 10 November 1995, 1ર̂, 1 ovig. ㅇ (MNHN-Na 15864); (iv) Îlot Crouy, 3 m, coll. Berthault, 15 June 1996, 1 ovig. ㅇ (MNHN-Na 15878).

Hosts

(ii) Goniopora sp.; (iii) sea anemone [Scleractinia; Actinaria, Coelenterata].

\section{Remarks}

Previously recorded from New Caledonia by Bruce (1996).

\section{Distribution}

Type locality: Heron Island, Queensland, 26-29 m. Also known from Vietnam, South China Sea, Japan, Philippines, Indonesia, Australia (Northern Territory, Queensland), and New Caledonia. 
Periclimenes novaecaledoniae Bruce, 1967

(Figure 26)

Periclimenes novaecaledoniae Bruce 1967b, p 1157-1165, Figures 6-9; Bruce 1991b, p 237;

Bruce 1996, p 237; Li 2000, p 215, Figure 279; Davie 2002, p 330.

\section{Material examined}

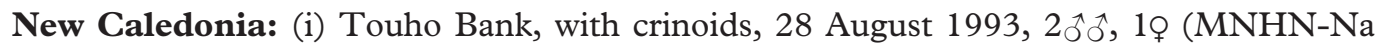
15895); (ii) MONTROUZIER, Koumac, Chenal Infernet, associated with crinoids, coll. B. Richer de Forges, photo. B. Rudman, 5 October 1993, 1 ovig. o (MNHN-Na 14919).
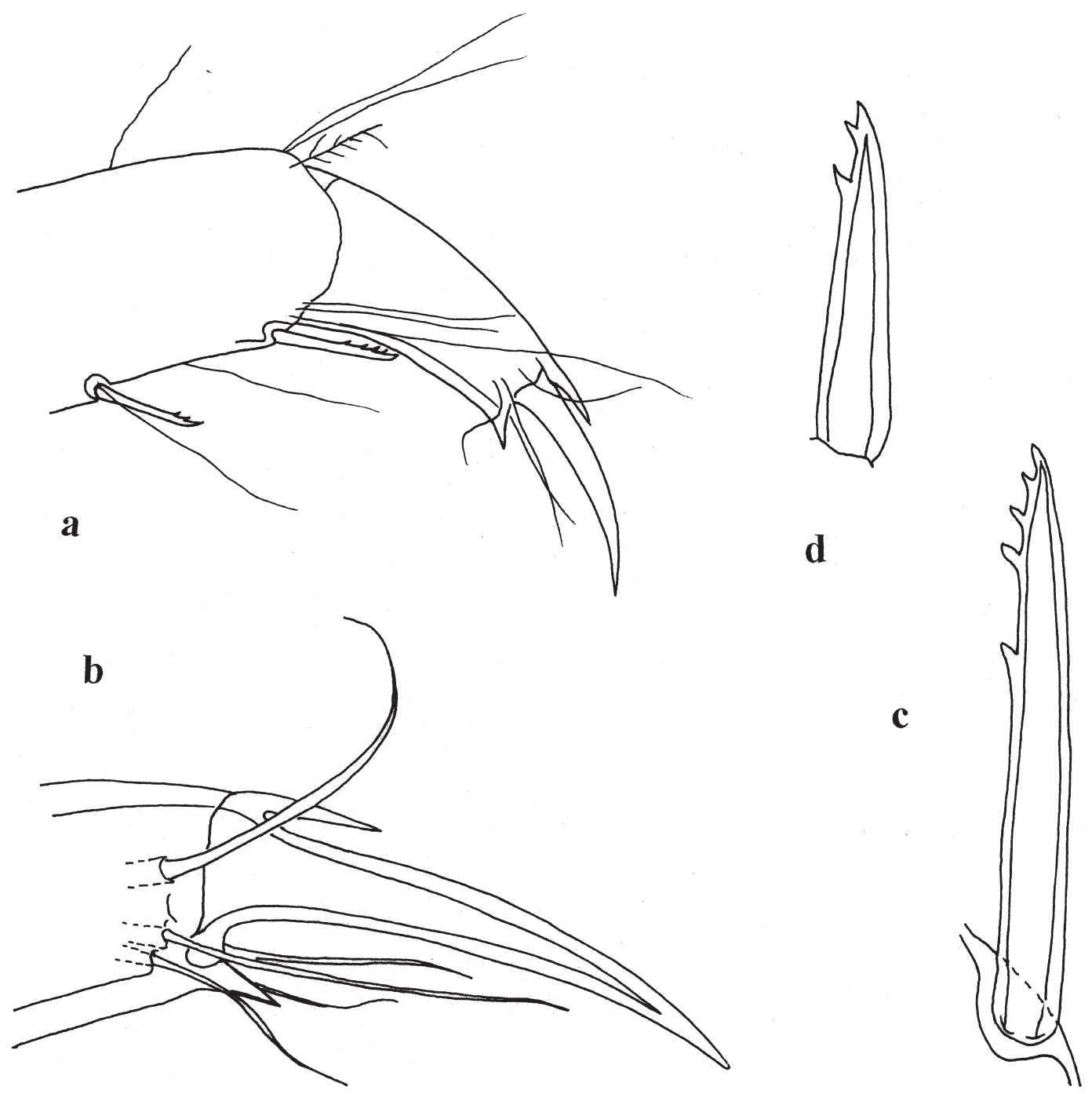

Figure 26. Periclimenes novaecaledoniae Bruce, 1967, ovigerous female (MNHN-Na 14919), third pereiopod. (a) Distal propod and dactyl; (b) distal corpus and unguis, dactyl; (c) distoventral propodal spine; (d) distal second ventral spine. 


\section{Remarks}

Originally described from New Caledonia. The specimen has a rostral dentition of 6/1 and has both second pereiopods, which are subequal, with the fingers strongly concave, subequal to the palm length, tridentate proximally, distally finely serrulate. Third pereiopod with dactyl biunguiculate with a dorsal spinule; propod spinulate, sparsely setose. The proximal segment of the antennular peduncle is strongly bidentate distolaterally.

\section{Distribution}

Type locality: Îlot Maitre, New Caledonia. Otherwise known only from Australia (Northern Territory), and possibly from Madagascar.

Periclimenes paralcocki sp. nov.

(Figure 27)

\section{Material examined}

Tuvalu: MUSORSTOM 7, Banc Bayonnaise, stn CP631, $11^{\circ} 54^{\prime} \mathrm{S}, 179^{\circ} 32^{\prime} \mathrm{W}, 600 \mathrm{~m}$, coll. 29 May 1992, 1o holotype (MNHN-Na 14865).

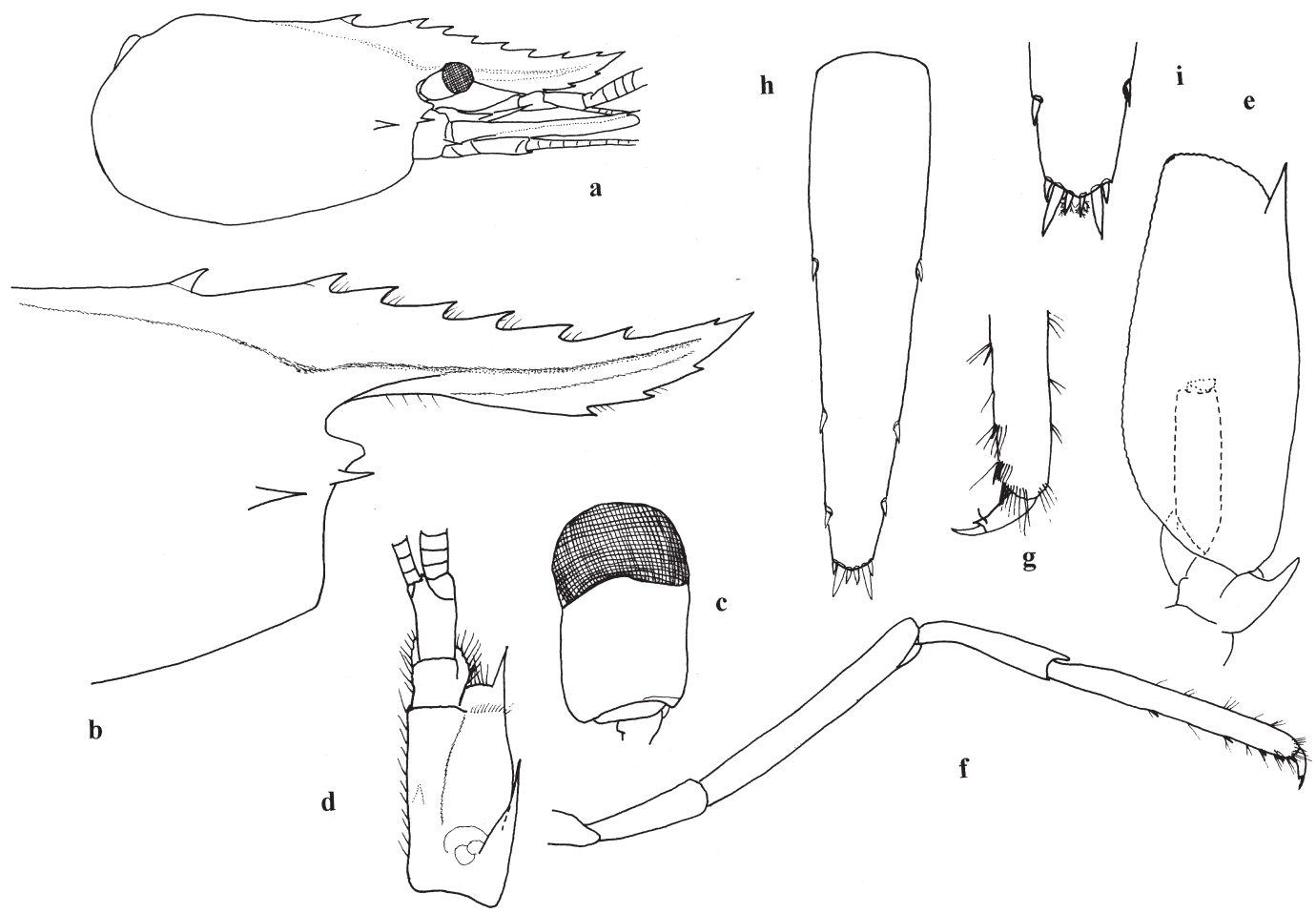

Figure 27. Periclimenes paralcocki, new species, holotype ovigerous female (MNHN-Na 14865). (a) Carapace and anterior appendages; (b) anterior carapace; (c) eye, dorsal view; (d) antennular peduncle; (e) antenna; (f) left third pereiopod; (g) same, distal propod and dactyl; (h) telson; (i) same, distal part. 


\section{Description}

A large pontoniine shrimp of subcylindrical body form, very similar to Periclimenes alcocki Kemp, 1922; lacking right (major?) second pereiopod.

Carapace smooth, glabrous, with feeble dorsal hump on posterior two-fifths. Rostrum well developed, compressed, moderately deep, anteroventrad mostly and slightly upcurved apically, with feeble dorsal curvature, distinctly overreaching antennular peduncle, extending near to tip of scaphocerite, about 0.7 of carapace length; dorsal carina distinct, with seven large, acute teeth evenly distributed along dorsal margin, distal tooth much smaller than proximal teeth, first tooth situated on carapace just behind level of posterior orbital margin, with feeble basal suture; lateral carinae well developed, horizontal except up-curved distal part; ventral margin with three teeth on distal half between fifth and seventh dorsal teeth; interdental spaces and proximal ventral carina feebly setose. Supraorbital spine absent; epigastric spine situated at anterior 0.25 of carapace length, with basal suture; orbit feebly developed, inferior orbital angle produced, oval rounded; antennal spine small slender marginal, distinctly below inferior orbital angle, not exceeding inferior orbital angle; hepatic spine larger than antennal spine, slender, slightly lower than antennal spine, below the level between epigastric spine and first dorsal rostral tooth, remote from anterior carapace margin; anterolateral angle of carapace not produced, bluntly rounded.

Abdominal segments smooth, glabrous; third abdominal segment not produced, noncarinate; pleura of first three segments broadly rounded, fourth and fifth posteriorly produced rounded, sixth segment about 1.75 times length of fifth, subcylindrical, about 1.54 times longer than central depth, posterolateral angle acute, posteroventral angle rounded. Telson about 1.9 times sixth segment length, slender, about 4.3 times longer than anterior width, lateral margins sublinear, convergent, dorsal surface with three pairs of dorsolateral spines at $0.41,0.73$, and 0.87 of telson length, spines about 0.034 of telson length; posterior margin about 0.34 of anterior margin width, rounded, without acute posterior median point; posterior margin with normal three pairs of spines, lateral spines short, similar to dorsolateral spines, intermediate spines long, robust, about 0.067 of telson length, submedian spines about 0.45 of intermediate spine length, with sparse plumose setose.

Eye moderately reduced, with globular cornea, corneal diameter 0.125 of postorbital carapace length, without accessory pigment spot; stalk feebly compressed, subuniform, diameter subequal to cornea, length subequal to corneal diameter, subequal to dorsal width.

Antennular peduncle overreaching second ventral rostral tooth; proximal segment about 1.75 times longer than central width, with slender acute stylocerite laterally, reaching to about 0.7 of segment length, anterolateral margin feebly produced, setose, with long slender acute lateral tooth overreaching distodorsal end of intermediate segment; statocyst small; medial margin near straight, setose, with ventromedial tooth at about 0.5 of length; intermediate segment with dorsal length about 0.26 of proximal segment length, subequal to width, lateral margin expanded, setose; distal segment about 0.43 times proximal segment length, slender, about 1.77 times longer than distal width; upper flagellum biramous, with 11 proximal segments of rami fused, shorter free ramus with five segments, length about 0.4 of fused portion, total length about 0.48 of carapace length, with about 26 groups of aesthetascs; longer ramus slender, filiform, about 0.93 of carapace length; lower flagellum slender, filiform, about 0.93 times carapace length.

Antennal basicerite robust, with acute distolateral tooth; carpocerite subcylindrical, about 0.39 of scaphocerite length, 3.25 times longer than width; flagellum well developed, 
slender, about 3.5 times postorbital carapace length; scaphocerite well developed, distinctly exceeding distal end of antennular peduncle, slightly overreaching rostral tip, broad, about 2.37 times longer than wide, greatest width at about 0.3 of length, distal margin bluntly rounded, slightly exceeding the distolateral tooth, lateral margin feebly convex, with strong acute distolateral tooth.

Epistome unarmed. Fourth thoracic sternite without slender median process, with broad triangular plates, separated by deep median fissure, fifth sternite similar, subequal to those of fourth; posterior sternites unarmed.

Mouthparts mainly undissected. Mandible without palp; incisor process distally with three (right) or four (left) stout acute teeth, central teeth smaller than outer teeth. Third maxilliped with slender endopod, extending distally to about 0.6 of carpocerite length, ischiomerus and basis fused incompletely, combined segment compressed, subuniform in ischiomerus portion and feebly produced medially in basal portion, setose medially, 5.4 times longer than central width; penultimate segment slightly compressed, about 0.53 of combined proximal segment length, with six groups of long finely spiniform setae medially; terminal segment about 0.37 of combined proximal segment length, 3.6 times longer than proximal width, distally tapering, with seven transverse groups of spiniform setae ventromedially, with long distal spiniform setae; exopod with slender flagellum just overreaching distal end of combined proximal segment, with nine plumose setae distally; coxa with small subacute setose medial process, rounded lateral plate, arthrobranch distinct.

First pereiopods moderately slender, extending slightly beyond distal margin of scaphocerite, exceeding carpocerite by chela and distal half carpus; chela with palm subcylindrical, slightly compressed, about 2.25 times longer than maximal depth, at about proximal 0.3 of length with six tranverse rows of short cleaning setae proximoventrally; fingers 0.86 of palm length, robust, tapering, subspatulate, surrounded by five groups of long setae medially and laterally along the fingers length, distal group shorter, cutting edges sharp, entire; carpus about 1.27 of chela length, 5.4 times longer than distal width, tapering proximally, with transverse row of serulate setae distoventrally; merus about 1.42 times chela length, 6.6 times longer than distal width, subuniform; ichium 0.64 of chela length, 2.7 times longer than distal width, feebly carinate distoventrally, obliquely articulated with basis; basis and coxa normal, no special feature.

Left (? minor) second pereiopod well developed, exceeding carpocerite by chela, carpus and distal sixth merus, scaphocerite by fingers and distal two-thirds of palm; chela subequal to postorbital carapace length; palm about 4.2 times longer than maximal depth, with very small tubercles; fingers about 0.6 of palm length, with strongly hooked tips, cutting edges entire, sharp, proximal 0.3 of fixed finger cutting edge with two small teeth, proximal one smaller, rounded, distal one larger, acute, proximal 0.4 of dactyl cutting edge with two small acute teeth, proximal tooth larger than distal; dactyl about 4.3 times longer than proximal depth, with feebly developed lateral flange; carpus cup-like, about 0.37 of palm length, 1.67 times distal width, with scattered small tubercles; merus about 0.8 of palm length, covered with scattered small tubercles; ischium 0.66 of palm length; basis and coxa normal.

Ambulatory pereiopods robust. Third pereiopod exceeds carpocerite by dactyl and propod, scaphocerite by dactyl; dactyl compressed, curved, about 0.15 of propod length, unguis distinct, about 0.54 of dorsal length of corpus, 4.2 times longer than proximal width; corpus about 2.38 times longer than proximal depth, dorsal margin feebly convex, non-setose, ventral margin largely straight, with acute distal accessory tooth, about 0.31 of 
unguis length, with short distolateral sensory setae; propod about 0.56 of carapace length, 9.3 times longer than maximum wide, subuniform, with pair of distovental spines and one pair of sub-distoventral spines, and three spines distributed along distal 0.6 of ventral margin, with row of long simple setae distolaterally, and group of long simple setae distodorsally, small groups of long simple setae along ventral and dorsal margins; carpus about 0.51 of propod length, 4.3 times longer than distal width, with long produced distodorsal lobe, unarmed; merus subequal to propod, 7.9 times longer than central width, uniform, unarmed; ischium 0.49 of propod length, 3.4 times longer than distal width, feebly tapered proximally; basis and coxa without special features. Fourth and fifth pereiopods similar to third, fourth propod subequal, fifth 1.09 times third propod length; fifth exceeds carpocerite by dactyl and distal one-third propod.

Pleopods without special features.

Uropod distinctly exceeding distal end of extended intermediate posterior spine of telson; protopodite with posterolateral angle short, rounded; exopod 2.59 times longer than central width, lateral border distinctly convex, with small acute distal tooth, and small mobile spine medially, diaeresis distinct; endopod about 0.93 of exopod length, 3.3 times longer than central width.

\section{Measurements (mm)}

Carapace length, 8.38; carapace and rostrum, 14.4; total body length (approximately), 40.0; left (? minor) second pereiopod chela, 8.23.

\section{Systematic position}

Periclimenes paralcocki n. sp. is very close to P. alcocki Kemp, 1922. The telson with three pairs of dorsolateral spines distinguishes the new species from $P$. alcocki and other related species immediately. Most of the other $P$. alcocki allied species, which are distributed in deep water and with more than two pairs of dorsolateral telson spines, have four pairs of dorsolateral telson spines except $P$. albatrossae Chace and Bruce, 1993, which has seven pairs of those spines. Periclimenes paralcocki can be distinguished from $P$. alcocki also by the relatively larger cornea, telson spines and accessory tooth of ambulatory pereiopod dactyl, and the rostrum distinctly reaching beyond the antennular peduncle, the flexor margin of ambulatory pereiopod propod is armed with spines and setae along the whole length. In $P$. alcocki, the rostrum does not exceed the antennular peduncle, the flexor margin of ambulatory pereiopod propod is unarmed except for the distal part. The number of dorsal telson spines of $P$. alcocki may show considerable variation (Bruce 1996, p 230), so the corneal diameter, length of rostrum, length of dorsolateral telson spines, and armature of ambulatory propod should be used to distinguish the allied species in the Periclimenes alcocki species group as well as the number of dorsolateral telson spines.

\section{Etymology}

Para (Greek), near, and the specific name alcocki, referring to the close relationship between the two species. 
Periclimenes paraleator sp. nov.

(Figure 28)

\section{Material examined}

New Caledonia: MUSORSTOM 4, stn 178, $18^{\circ} 56.3^{\prime} \mathrm{S}, 163^{\circ} 12.9^{\prime} \mathrm{E}, 520 \mathrm{~m}, 18$ September 1985, 1 ovig. ㅇ holotype (MNHN-Na 14945).

\section{Description}

A medium-sized pontoniine shrimp of subcylindrical body form, very similar to Periclimenes aleator Bruce, 1991; both second pereiopods lost.

Carapace smooth, glabrous. Rostrum well developed, compressed, shallow, horizontal, with distinct dorsal curvature, slightly extending antennal scale, about 0.86 of carapace length; dorsal carina distinct, with seven long, acute subequal teeth along proximal 0.6 rostral length and anterior dorsal carapace, and minute subapical tooth, first tooth situated on carapace, second just above posterior orbital margin; lateral carinae feebly developed; ventral margin with four teeth on distal 0.6 ventral rostral length, first two long, similar to dorsal teeth, third tooth much smaller than first two, distal tooth subapical, minute, smaller than subapical dorsal tooth; interdental spaces and proximal ventral carina feebly setose. Supraorbital spine absent; epigastric spine situated at anterior 0.3 of the carapace length, with basal suture; orbit feebly developed, inferior orbital angle acutely produced, oval; antennal spine small, slender, marginal, distinctly below inferior orbital angle, not exceeding inferior orbital angle; hepatic spine larger than antennal spine, slender, slightly lower than antennal spine, below first dorsal rostral tooth, remote from anterior carapace margin; anterolateral angle of carapace not produced, bluntly rounded.

Abdominal segments smooth, glabrous; third abdominal segment not produced, noncarinate; pleura of first three segments broadly rounded, fourth and fifth posteriorly produced rounded, sixth segment about 1.6 times length of fifth, subcylindrical, about 1.8 times longer than deep, subuniform, posterolateral angle acute, posteroventral angle rounded. Telson about 1.62 times sixth segment length, slender, about 4.4 times longer than anterior width, lateral margins sublinear, with anterior third curved ventrally, subparallel, posterior two-thirds straight, convergent, dorsal surface with four pairs of welldeveloped dorsolateral spines at $0.39,0.54,0.67$, and 0.84 of telson length, spines about 0.044 of telson length; posterior margin about 0.39 of anterior margin width, rounded, without acute posterior median point; posterior margin with normal three pairs of spines, lateral spines short, similar to dorsolateral spines, intermediate spines long, robust, about 0.09 of telson length, submedian spines about 0.47 of intermediate spine length.

Eye moderate large, with globular cornea, corneal diameter 0.16 of posterior orbital carapace length, without accessory pigment spot; stalk compressed, distinctly narrower than cornea in lateral view, 0.8 of corneal diameter, 1.22 times lateral width and 0.93 of dorsal maximum width.

Antennular peduncle overreaching second ventral rostral tooth; proximal segment about 2.0 times longer than central width, with slender acute stylocerite laterally, reaching to about 0.7 of segment length, anterolateral margin feebly produced, setose, with long slender acute lateral tooth reaching to about 0.6 of intermediate segment length; statocyst small; medial margin near straight, setose, with ventromedial tooth at about 0.5 of length; intermediate segment with dorsal length about 0.26 of proximal segment length, subequal to width, lateral margin expanded, setose; distal segment about 0.41 times proximal 


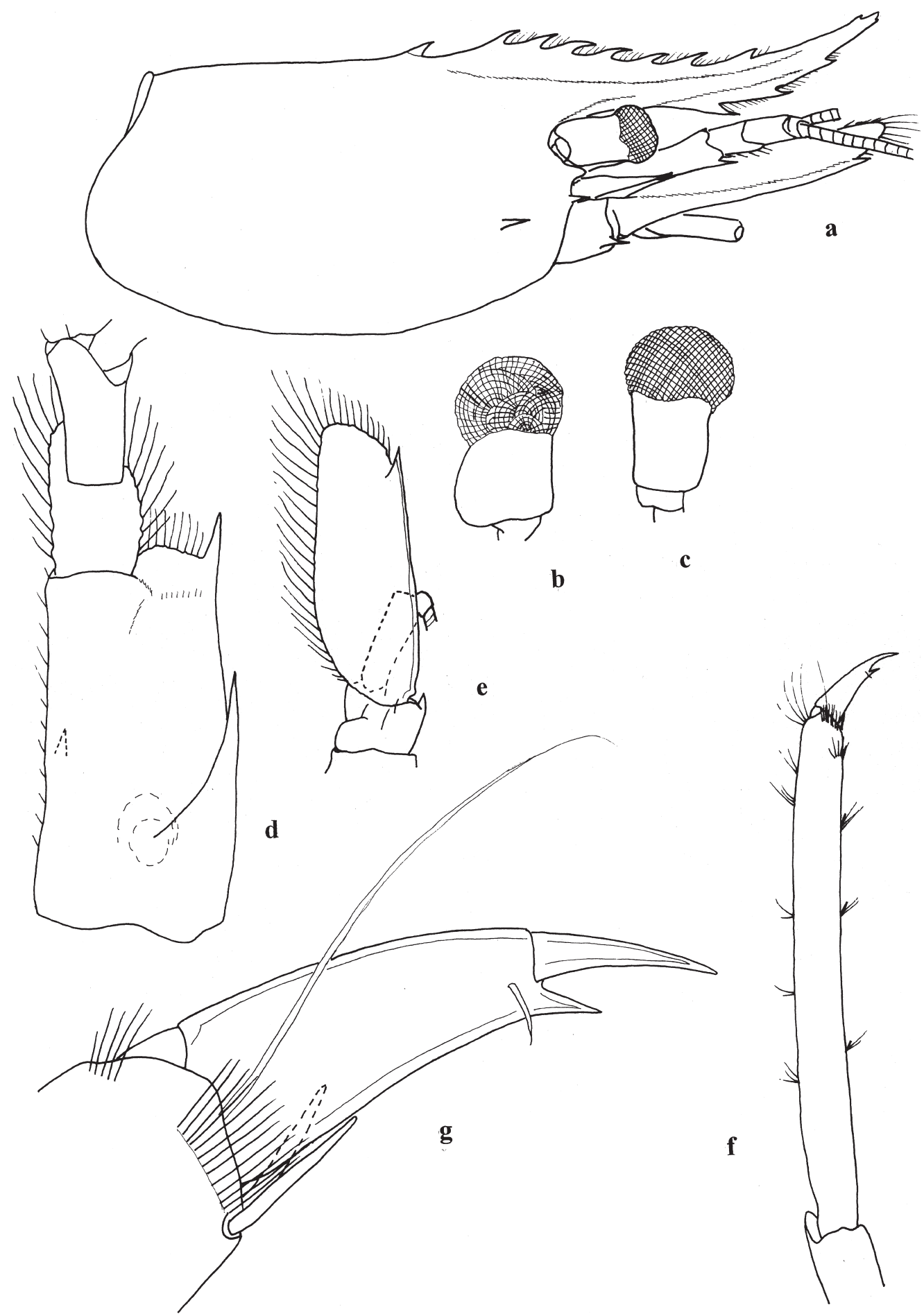

Figure 28. Periclimenes paraleator, new species, holotype ovigerous female (MNHN-Na 14945). (a) Carapace and anterior appendages; (b) eye, dorsal view; (c) same, lateral view; (d) antennular peduncle; (e) antenna; (f) third pereiopod, propod and dactyl; (g) same, distal propod and dactyl. 
segment length, slender, about 1.75 times longer than distal width; upper flagellum biramous, with 11 proximal segments of rami fused, shorter free ramus with five segments, length about 0.42 of fused portion, total length about 0.54 of carapace length, with about 25 groups of aesthetascs; longer ramus slender, filiform, about 0.7 of carapace length; lower flagellum slender, filiform, about 0.95 times carapace length.

Antennal basicerite robust, with acute distolateral tooth; carpocerite subcylindrical, about 0.35 of scaphocerite length, 3.0 times longer than width; flagellum well developed, slender, more than 2.4 times postorbital carapace length; scaphocerite well developed, distinctly exceeding distal end of antennular peduncle, reaching beyond third ventral rostral tooth, broad, about 2.85 times longer than wide, greatest width at about 0.35 of length, distal margin bluntly rounded, distinctly exceeding distolateral tooth, lateral margin nearly straight, with strong acute distolateral tooth.

Epistome unarmed. Fourth thoracic sternite without slender median process, with broad triangular plates, separated by deep median fissure, fifth sternite similar, lateral plates smaller; posterior sternites unarmed.

Mouthparts mainly undissected. Mandible without palp; incisor process distally with three (right) or four (left) stout acute teeth, central teeth smaller than outer teeth. Third maxilliped with slender endopod, extending distally to middle of carpocerite, ischiomerus and basis fused completely, combined segment compressed, subuniform, setose medially, 6.1 times longer than central width; penultimate segment slightly compressed, about 0.57 of combined proximal segment length, with five groups of long finely spiniform setae medially; terminal segment about 0.45 of combined proximal segment length, 4.7 times longer than proximal width, distally tapering, with six transverse groups of spiniform setae ventromedially, with long distal spiniform setae; exopod with slender flagellum extending to distal end of combined proximal segment, with seven plumose setae distally; coxa with small subacute setose medial process, rounded lateral plate, arthrobranch distinct.

First pereiopods moderately slender, extending to tip of rostrum, exceeding carpocerite by chela and distal two-thirds carpus; chela with palm subcylindrical, slightly compressed, about 2.0 times longer than maximal depth, at about proximal 0.3 of length with six tranverse rows of short cleaning setae proximoventrally; fingers 0.93 of palm length, robust, tapering, surrounded by three groups of long setae medially and laterally, distally with shorter setae, cutting edges sharp, entire; carpus about 1.28 of chela length, 5.0 times longer than distal width, tapering proximally, with transverse row of serrulate setae distoventrally; merus about 1.5 times chela length, 7.4 times longer than distal width, subuniform; ichium 0.68 of chela length, 3.6 times longer than distal width, feebly carinate distoventrally, obliquely articulated with basis; basis 0.47 of chela length; coxa normal, with small, non-setose distoventral process.

Ambulatory pereiopods slender. Third pereiopod exceeds carpocerite by dactyl and propod, scaphocerite by dactyl; dactyl compressed, curved, about 0.19 of propod length, unguis distinct, about 0.51 of dorsal length of corpus, 3.64 times longer than proximal width; corpus about 2.2 times longer than proximal depth, dorsal margin feebly convex, non-setose, ventral margin largely straight, with acute distal accessory tooth, about 0.35 of unguis length, with short distolateral sensory setae; propod about 0.48 of carapace length, 10.5 times longer than maximum wide, subuniform, with pair of distoventral spines and four spines distributed along distal three-quarters ventral margin, with row of long simple setae distolaterally, and group of long simple setae distodorsally, small groups of long simple setae along ventral and dorsal margins; carpus about 0.56 of propod length, 5.1 times longer than distal width, with long produced distodorsal lobe, unarmed; merus 1.16 
of propod length, 10.0 times longer than central width, uniform, unarmed; ischium 0.64 of propod length, 4.9 times longer than distal width, feebly proximally tapered; basis and coxa without special features. Fourth and fifth pereiopods similar to third, fourth propod 1.08, fifth propod 1.14 times third propod length; fifth exceeds carpocerite by dactyl and half propod.

Pleopods without special features.

Uropod distinctly exceeding distal end of extending intermediate posterior spine of telson; protopodite with posterolateral angle short, rounded; exopod 2.76 times longer than central width, lateral border distinctly convex, with small acute distal tooth, with large mobile spine medially, diaeresis distinct; endopod about 0.97 of exopod length, 3.5 times longer than wide.

Ova small, numerous, more than 300 .

Measurements ( $\mathrm{mm}$ )

Carapace length, 6.03; carapace and rostrum, 11.06; total body length (approximately), 30.1 ; length of ovum, 0.65 .

\section{Systematic position}

Periclimenes paraleator $\mathrm{n}$. sp. is very close to P. aleator Bruce, 1991. It can be distinguished from the latter by the longer rostrum which distinctly exceeds the scaphocerite. In $P$. aleator, the rostrum also reaches slightly beyond the antennular peduncle. Also, the new species has a more robust body and relatively shorter ambulatory pereiopods than $P$. aleator. Periclimenes paraleator is also similar to $P$. alcocki Kemp, 1922. It can be distinguished from the latter by the longer rostrum, larger cornea and more developed dorsolateral telson spines and the propods of ambulatory pereiopods with spinules along most ventral margin.

\section{Etymology}

Para (Greek), near, and the specific name aleator, referring to the close relationship between the two species.

\section{Remarks}

In the deep-water Periclimenes species with more than two pairs of dorsolateral telson spines, only $P$. albatrossae Chace and Bruce, 1993 has the rostrum exceeding the scaphocerite. Periclimenes paraleator can be distinguished immediately from that species by having only four pairs of dorsolateral telson spines. In P. albatrossae, seven pairs of those spines are present. In addition, the propod of ambulatory pereiopods in $P$. albatrossae is unarmed on the flexor margin. 
Periclimenes pilipes Bruce and Zmarzley, 1983

(Figure 29)

Periclimenes pilipes Bruce and Zmarzly 1983, p 644-654, Figures 1-6; Chace and Bruce 1993, p 119; Li 2000, p 226, Figure 297.

\section{Material examined}

Philippines: Maribago, Mactan Island, Cebu, $10^{\circ} 17^{\prime} \mathrm{N}, 124^{\circ} 00^{\prime} \mathrm{E}, 3-5 \mathrm{~m}$, washings from mixed crinoids, coll. P. Bouchet, 9 June 1985, 1ิึ, 1 juvenile $q$ (MNHN-Na 14920).

Hosts

Comanthina schlegeli (P. H. Carpenter, 1881), Comatella nigra (P. H. Carpenter, 1888), Comanter multibrachiata (P. H. Carpenter, 1888), Comanthus bennetti (J. Müller, 1841), det. A. M. Clark [Crinoidea, Echinoderma].

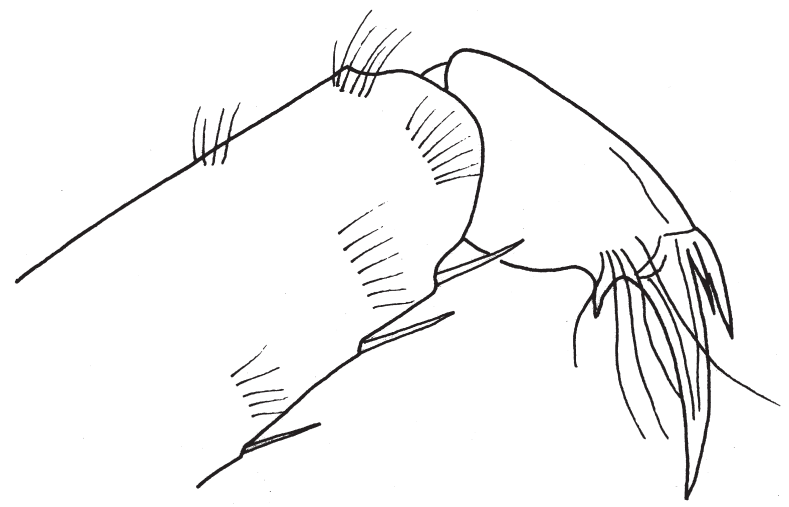

a

b

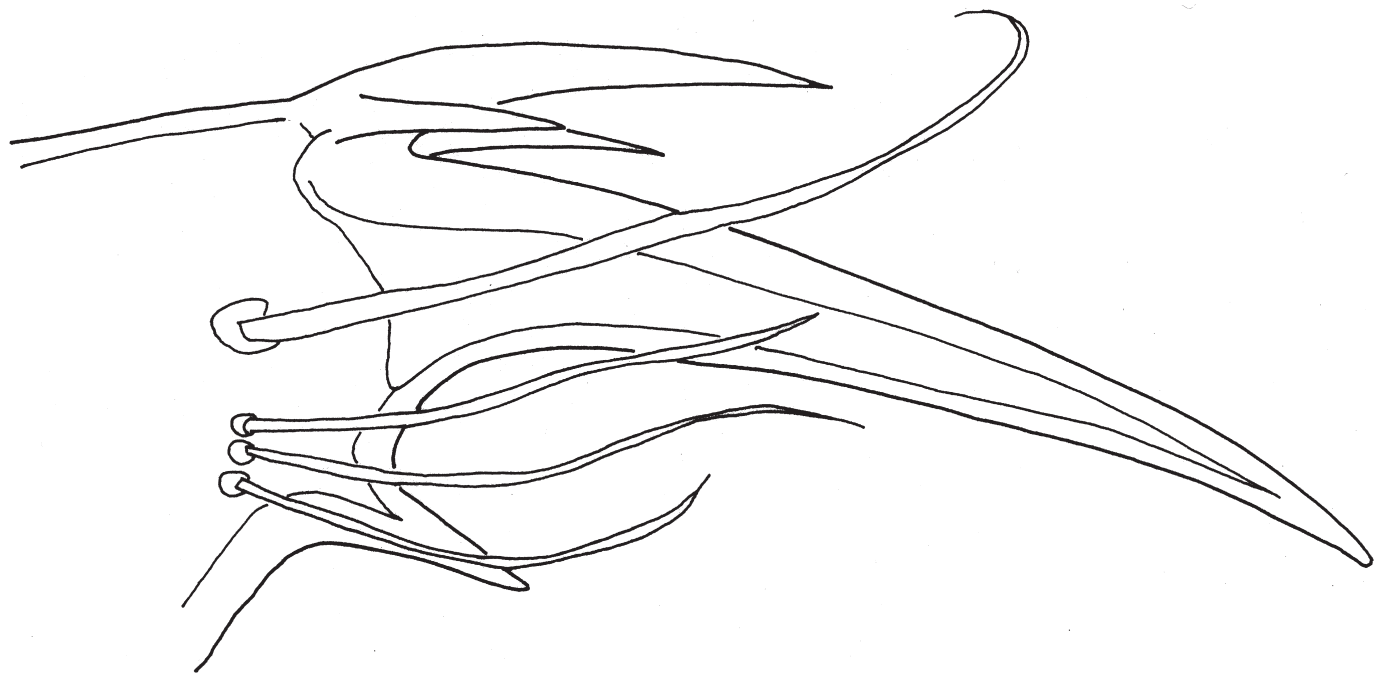

Figure 29. Periclimenes pilipes Bruce and Zmarzley, 1983 (MNHN-Na 14920). (a) Third pereiopod, distal propod and dactyl; (b) same, distal corpus and unguis. 
Remarks

Previously reported from Moalboal Island in the Philippines by Bruce (1989a). The male specimen, cl $2.5 \mathrm{~mm}$, has a rostral dentition of $6 / 2$ and the female, $5 / 1$. The first pereiopod has the fingers feebly subspatulate; second pereiopods stout, carpus short, merus unarmed; third pereiopod with dactyl biunguiculate, with conspicuous trifid dorsal spine on proximal unguis, propod with long straight stiff setae. Proximal segment of antennular peduncle strongly bidentate distolaterally.

\section{Distribution}

Type locality: Eniwetak Atoll, Marshall Islands. So far, known only from Marshall Islands and Philippines.

Periclimenes platyrhynchus Bruce, 1991

Periclimenes platyrhynchus Bruce 1991a, p 358, Figures 41-44; Li 2000, p 227, Figure 300.

\section{Material examined}

New Caledonia: BATHUS 4, stn DW942, $19^{\circ} 04.26^{\prime} \mathrm{S}, 163^{\circ} 27.36^{\prime} \mathrm{E}, 270-264 \mathrm{~m}, 8$ August 1994, 2રิô, 3 ovig. 우 (MNHN-Na 15922).

\section{Remarks}

Previously known only from the type locality New Caledonia.

\section{Distribution}

Type locality: only, New Caledonia.

Periclimenes pseudalcocki sp. nov.

(Figure 30)

\section{Material examined}

Indonesia: KARUBAR, Kai Islands, stn CP16, 517'S, $132^{\circ} 50^{\prime} \mathrm{E}, 315-349 \mathrm{~m}, 24$ October 1991, 1o holotype (MNHN-Na 14855).

\section{Description}

A large pontoniine shrimp of subcylindrical body form, very similar to Periclimenes alcocki Kemp, 1922.

Carapace smooth, glabrous. Rostrum well developed, compressed, deep, especially anteroventrally and distinctly upcurved distally, distinctly overreaching antennular peduncle, extending near to tip of scaphocerite, about 0.68 of carapace length; dorsal margin with seven low acute teeth, first tooth situated on carapace just behind level of posterior orbital margin; lateral carinae well developed, except upcurved distal part; ventral margin with two small acute teeth on distal third and subapical small tubercle, first tooth at level of last dorsal tooth. Supraorbital spine absent; epigastric spine similar to dorsal rostral 


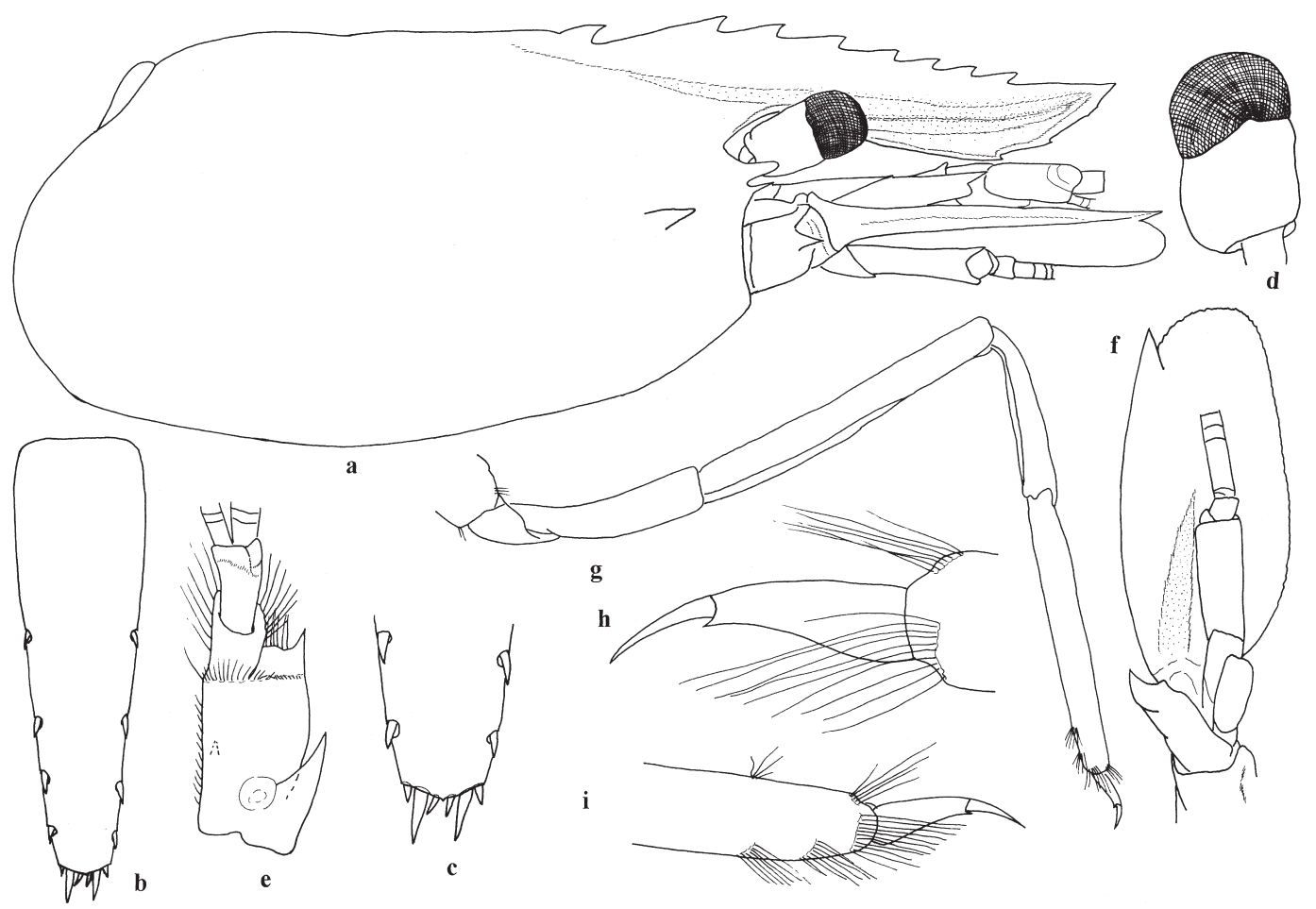

Figure 30. Periclimenes pseudalcocki, new species, holotype female (MNHN-Na 14855). (a) Carapace and anterior appendages; (b) telson; (c) same, distal part; (d) eye, dorsal view; (e) antennular peduncle; (f) antenna; (g) third pereiopod; (h) same, distal propod and dactyl, lateral view; (i) same, medial view.

tooth, situated at anterior 0.23 of carapace length; orbit feebly developed, inferior orbital angle produced, oval rounded; antennal spine small slender marginal, distinctly below the inferior orbital angle, not exceeding inferior orbital angle; hepatic spine larger than antennal spine, stout, slightly lower than antennal spine, below level between epigastric spine and first dorsal rostral tooth, remote from anterior carapace margin; anterolateral angle of carapace not produced, bluntly rounded.

Abdominal segments smooth, glabrous; third abdominal segment not produced, noncarinate; pleura of first three segments broadly rounded, fourth and fifth posteriorly produced rounded, sixth segment about 2.0 times length of fifth, subcylindrical, about 1.52 times longer than central depth, posterolateral angle acute, posteroventral angle rounded. Telson about 1.64 times sixth segment length, slender, about 3.35 times longer than anterior width, lateral margins sublinear, convergent, dorsal surface with four pairs of dorsolateral spines at $0.45,0.64,0.78$ (average), and 0.90 (average) of telson length, dorsal spines about 0.045 of telson length; posterior margin about 0.40 of anterior margin width, rounded, with minute sharp posterior median point; posterior margin with normal three pairs of spines, lateral spines short and robust, similar to dorsolateral spines, intermediate spines long, robust, about 0.075 of telson length, submedian spines about 0.41 of intermediate spine length, non-setulose. 
Eye reduced, with globular cornea, corneal diameter 0.11 of posterior orbital carapace length, without accessory pigment spot; stalk feebly compressed, subuniform, dorsal width subequal to corneal diameter, length 0.95 of corneal diameter.

Antennular peduncle overreaching second ventral rostral tooth; proximal segment about 1.43 times longer than central width, with slender acute stylocerite laterally, reaching to about 0.7 of segment length, anterolateral margin feebly produced, setose, with long slender acute lateral tooth overreaching distodorsal end of intermediate segment; statocyst small; medial margin near straight, setose, with ventromedial tooth at about 0.54 of length; intermediate segment with dorsal length about 0.3 of proximal segment length, subequal to width, lateral margin expanded, setose, medial margin strongly setose; distal segment about 0.54 times proximal segment length, slender, about 1.7 times longer than distal width; upper flagellum well developed, biramous, with proximal 12 segments fused, shorter free ramus with four segments, length about 0.28 of fused portion, total length about 0.49 of carapace length, with about 28 groups of aesthetascs; longer ramus slender, filiform, about 0.55 of carapace length; lower flagellum slender, filiform, about 0.83 times carapace length.

Antennal basicerite robust, with strong acute distolateral tooth; carpocerite subcylindrical, about 0.39 of scaphocerite length, 2.67 times longer than width; flagellum well developed, slender, about 2.0 times postorbital carapace length; scaphocerite well developed, distinctly exceeding rostral tip, broad, about 2.16 times longer than wide, greatest width at about 0.3 of length, distal margin bluntly rounded, slightly exceeding the distolateral tooth, lateral margin feebly convex, with strong acute distolateral tooth.

Epistome unarmed. Fourth thoracic sternite without slender median process, with broad triangular plates, separated by deep median notch, fifth sternite similar, subequal to those of fourth; posterior sternites unarmed.

Mouthparts mainly undissected. Mandible without palp; incisor process distally with three (right) or four (left) stout acute teeth, central teeth smaller than outer teeth. Third maxilliped reaching to distal end of carpocerite, similar to that of $P$. alcocki, coxa with arthrobranch distinct.

First pereiopods moderately slender, exceeding distal margin of antennal scale by chela, exceeding carpocerite by chela and five-sixths carpus; similar to that of $P$. alcocki.

Second pereiopods well developed, subsimilar except the fingers, chelae covered with small tubercles. Major (right) pereiopod exceeding distal end of antennal scale by chela, carpocerite by chela, carpus and distal third merus; minor (left) pereiopod also exceeding distal end of antennal scale by chela, carpocerite by chela, carpus and distal third merus. Other features very similar to those of $P$. alcocki.

Ambulatory pereiopods slender. Third pereiopod exceeds carpocerite by dactyl, propod and distal two-fifths carpus, scaphocerite by dactyl and half propod; dactyl compressed, slender, curved, about 0.18 of propod length, unguis distinct, about 0.62 of dorsal length of corpus, 5.5 times longer than proximal width; corpus about 2.57 times longer than proximal depth, dorsal margin feebly convex, non-setose, ventral margin largely feebly concave, except feebly convex proximal portion, distal accessory tooth acute, minute, about 0.11 of unguis length, with single short distolateral sensory seta; propod compressed, subuniform, about 0.52 of carapace length, 8.3 times longer than wide, with three transverse rows of long simple setae distoventrally and one row of similar setae distodorsally, without distoventral spines, major part of ventral border unarmed, nonsetose; carpus feebly compressed, tapering feebly proximally, about 0.59 of propod length, 4.9 times longer than distal width, with long produced distodorsal lobe, unarmed; merus 
compressed and feebly twisted, 1.16 of propod length, 7.9 times longer than central width, uniform, unarmed; ischium compressed, 0.64 of propod length, 4.0 times longer than distal width, feebly proximally tapered; basis and coxa without special features. Fourth and fifth pereiopods similar to third, fourth propod 1.1 of third propod length, fifth propod subequal to fourth; fourth and fifth dactyl with the accessory tooth very minute, like tubercle; fifth exceeds carpocerite by dactyl and distal two-thirds propod, scaphocerite by dactyl.

Pleopods without special features.

Uropod distinctly exceeding distal end of telson, exopod reaching the distal tip of extended intermediate posterior spines; protopodite with distolateral lobe broadly rounded; exopod 2.17 times longer than central width, lateral border feebly convex, with small distal tooth, and larger mobile spine medially, diaeresis distinct, at 0.75 of length; endopod subequal to exopod length, 2.7 times longer than central width.

\section{Measurements ( $\mathrm{mm}$ )}

Carapace length, 8.64; carapace and rostrum, 14.2; total body length (approximately), 40.0; right (major) second pereiopod chela, 10.32; left (minor) second pereiopod chela, 7.88 .

\section{Systematic position}

Periclimenes pseudalcocki n. sp. is very close to P. alcocki Kemp, 1922. It can be distinguished from the latter by the smaller accessory tooth of ambulatory dactyl which is at most 0.11 of unguis length (in third pereiopod, it is like a tubercle in the fourth and fifth pereiopod), and the propod has no distoventral or ventral spines. In $P$. alcocki, the accessory tooth of ambulatory dactyl is about 0.2 of unguis length, and propod has one distoventral spine and two ventral spines. In addition, the rostrum of $P$. pseudalcocki is deeper, and dorsal telson spines larger (about 0.045 of telson length, it is 0.03 in P. alcocki). Periclimenes pseudalcocki can be distinguished from other allied deep-water species with four pairs of dorsolateral telson spines by the markedly reduced cornea, the corneal diameter 0.11 of carapace length. Periclimenes pseudalcocki is also very similar to $P$. crosnieri $\mathrm{n}$. $\mathrm{sp}$. It can be distinguished from that species by the biunguiculate third pereiopod dactyl, non-spinules propod, reduced cornea, and other detailed features.

\section{Etymology}

Pseudos (Greek), fallacy, and the specific name alcocki, referring to the close relationship between the two species.

Key to the species of Periclimenes alcocki species group

1. Telson with seven pairs of dorsolateral spines; rostrum overreaching scaphocerite; third pereiopod with dactyl truncate subdistally, propod without spinules on flexor margin P. albatrossae Chace and Bruce, 1993 
- Telson with three to five pairs of dorsolateral spines .

2. Telson with three pairs of dorsolateral spines; rostrum not overreaching scaphocerite; corneal diameter about 0.125 of carapace length, eye stalk not distinctly narrower than cornea; dorsal rostral margin concave; third pereiopod with propod with spinules on flexor margin, and transverse setal rows distally and spines; R. $1+7 / 3$

P. paralcocki sp. n.

- Telson with four to five pairs of dorsolateral spines .

3. Rostrum overreaching scaphocerite; corneal diameter about 0.16 of carapace length, eye stalk distinctly narrower than cornea lateral view; dorsal rostral margin concave; third pereiopod with propod with spinules on flexor margin, and transverse setal rows distally and spines; R. 1+7+1/4 .

$P$. paraleator sp. n.

- Rostrum not overreaching scaphocerite.

4. Cornea markedly reduced, diameter about 0.1 of carapace length .

- Cornea not markedly reduced, diameter more than 0.13 of carapace length; dorsal telson spines not minute .

5. Ambulatory pereiopods with propod without distoventral or ventral spines, dactyl with accessory tooth minute, at most 0.11 of unguis length; rostrum relatively deep, distally with a strong upward curve; dorsal telson spines relatively large, 0.045 of telson length; R. 1+7/2 . . . . . . . . . P. pseudalcocki sp. n.

- Ambulatory pereiopods with propod with distoventral and ventral spines . . . 6

6. Corneal diameter about 0.075 of carapace length; hepatic spine at about same level of posterior rostral series (epigastric) tooth; third pereiopod dactyl 0.17 of propod length, accessory tooth about 0.2 of unguis length; dorsal telson spines minute, about 0.03 telson length; R. 2+6-8/2-4 (1+9/3) . P. alcocki Kemp, 1922

- Corneal diameter about 0.1 of carapace length; hepatic spine anterior to level of posterior rostral series (epigastric) tooth; third pereiopod dactyl about 0.28 of propod length, accessory tooth about 0.07 of unguis length; dorsal telson spines minute, about 0.04 telson length; R. 1+7/1 . . . . P. tangeroa Bruce, 2005

7. Ambulatory dactyl with accessory tooth almost as long as unguis, laterally twisted; R. $1+7-9 / 2-3$. . . . . . . . . . . . . P. poupini Bruce, 1990

- Ambulatory dactyl with accessory tooth not unusually long or twisted. . . $\quad 8$

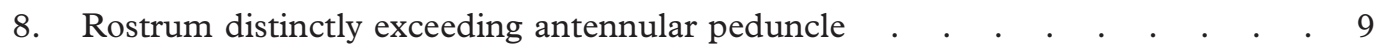

- Rostrum not reaching end of antennal peduncle; pigmented cornea large, diameter about $0.16-0.18$ of carapace length .

9. Hepatic spine distinctly lower than antennal spine; R. 1-2+5-9/3-4 .

P. aleator Bruce, 1991

- Hepatic spine very slightly lower than, almost at same level of antennal spine; R. $2+6 / 3$ P. loyautensis sp. n.

10. Rostrum deeper, proximally not elevated over orbital region, upturned in female, ventral margin convex, with two teeth; ambulatory dactyl with accessory tooth about 0.3 of unguis length; R. $1+5-6 / 2$. . . . . P. brevirostris Bruce, 1991

- Rostrum shallower, proximally elevated over orbital region, tapered distally, ventral margin straight, with one tooth; ambulatory dactyl with accessory tooth reaching about proximal 0.4 of unguis length; R. 1+6-7/1 . . . P. forgesi sp. n. 
Periclimenes soror Nobili, 1904

Periclimenes soror Nobili 1904, p 232.

Periclimenes (Periclimenes) soror: Holthuis 1952a, p 51-53, Figure 17.

Periclimenes soror Bruce 1976c, p 299-306, Figures 1-6; Wicksten and Hendrickx 1985, p 571; Chace and Bruce 1993, p 122; Li 2000, p 237, Figure 316; Davie 2002, p 332; Li and Liu 2004, p 95, Figure 7.

Material examined

New Caledonia: (i) MONTROUZIER, Koumac, $25 \mathrm{~m}, 26$ October 1993, $1 \hat{\jmath}, 1$ q (MNHN-Na 14924). Loyalty Islands: (ii) ATELIER LIFOU, Lifou, Santal Bay: westsouthwest of Easo Point, stn $1429,20^{\circ} 47.5^{\prime} \mathrm{S}, 167^{\circ} 07.1^{\prime} \mathrm{E}, 8-18 \mathrm{~m}$, coral heads,

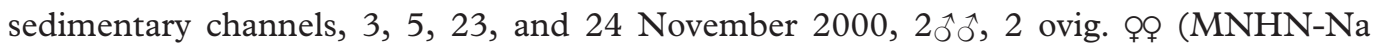
15540).

Host

Echinaster luzonicus (Grey, 1849) [Asteroidea, Echinoderma].

Remarks

The specimens had the accessory tooth on the ambulatory dactyls minute, virtually obsolete. The distolateral angle of the proximal segment of the antennular peduncle was strongly bidentate, but tridentate on the left side in the female.

\section{Distribution}

Type locality: Djibouti. Also known from the Red Sea, Kenya, Zanzibar, Tanzania, Madagascar, Comoro Islands, Seychelles, Chagos Islands, Malaysia (Sabah), China (Hong Kong), Japan, Philippines, Indonesia, Australia (Western Australia, Northern Territory, Queensland, New South Wales), Marianas Islands, Caroline Islands, Solomon Islands, New Caledonia, Loyalty Islands, Marshall Islands, Fiji, French Polynesia (Society Islands, Tuamotu Islands), and Hawaii. Also known from the East Pacific region, the Gulf of California, Mexico, Panama, and Columbia.

Periclimenes tosaensis Kubo, 1951

Periclimenes (Ancylocaris) tosaensis Kubo 1951, p 268, Figures 7, 8.

Periclimenes (Harpilius) tosaensis: Bruce 1966b, p 15, Figures 1, 2, 3a, 4a, b.

Periclimenes tosaensis: Bruce 1976a, p 106, Figure 12; Bruce 1981a, p 196, Figure 5; Li 2000, p 243, Figure 323; Li 2004b, p 821; Li et al. 2004, p 548, Figure 33.

Material examined

Fiji: MUSORSTOM 10, south Viti Levu, stn CP 1363, $18^{\circ} 12.4^{\prime} \mathrm{S}, 178^{\circ} 33.0^{\prime} \mathrm{E}, 1_{4}-$ $150 \mathrm{~m}, 15$ August 1998, 1 ovig. @ (MNHN-Na 15541).

Remarks

Not previously recorded from Fiji.

\section{Distribution}

Type locality: Tosa Bay, Shikoku, Japan. Also known from Seychelles, South China Sea, East China Sea, Philippines, and Fiji. 
Periclimenes uniunguiculatus Bruce, 1990

Periclimenes uniunguiculatus Bruce 1990a, p 167, Figures 12-15, 39e; Bruce 1996, p 239241, Figures 14d-f, 28g; Li 2000, p 244, Figure 324.

Periclimenes sp. A Bruce 1991a, p 371.

\section{Material examined}

New Caledonia: (i) BERYX 11, south New Caledonia, stn DW27, 233' $\mathrm{S}, 167^{\circ} 41^{\prime} \mathrm{E}$, 460-470 m, 18 October 1992, 1 ovig. ᄋ (MNHN-Na 14885); (ii) BATHUS 3, stn CP832, $23^{\circ} 03.07^{\prime} \mathrm{S}, 166^{\circ} 53.70^{\prime} \mathrm{E}, 650-669 \mathrm{~m}, 30$ November 1993, 1 ( $(\mathrm{MNHN}-\mathrm{Na} 14941$ ); (iii) HALIPRO 2, Norfolk Ridge, stn BT60, 24 ${ }^{\circ} 52^{\prime} \mathrm{S}, 1^{\circ} 8^{\circ} 44^{\prime} \mathrm{E}, 1133-1280 \mathrm{~m}, 18$ November 1996, 1ㅇ (MNHN-Na 15880).

\section{Remarks}

The specimens fit the original description and illustrations of the species very well, except for the larger body size with the postorbital carapace length $6.1 \mathrm{~mm}$. The smaller body size of the holotype male may be caused by the bopyrid parasites present.

One of the authors $(\mathrm{X} . \mathrm{Li})$ checked the ovigerous female (MNHN-Na 12870) reported by Bruce (1996, under the name of P. uniunguiculatus, from Comoro Islands, at a depth of $500 \mathrm{~m}$ ) and the adult female (MNHN-Na 12042) reported by Bruce (1991a, under the name of $P$. sp. A, from New Caledonia, at a depth of $825-860 \mathrm{~m}$ ), during his visit to the museum (MNHN, Paris, 2004), and found that they are conspecific. Unfortunately, the holotype male was absent then. Anyway, both specimens mostly fit Bruce's (1990a) description. We are now sure the specimen of Bruce's (1991a) P. sp. A is identical to the present species. The present records extend the bathymetric range of the species from 460 to $1280 \mathrm{~m}$.

\section{Distribution}

Type locality: New Caledonia. Also known from Comoro Islands (Bruce, 1996).

Periclimenes vaubani Bruce, 1990

Periclimenes vaubani Bruce 1990a, p 174, Figures 16-19, 38a-d; Bruce 1991a, p 315; Bruce 2005, p 4, Figure 1; Li 2000, p 245, Figure 325.

\section{Material examined}

New Caledonia: (1) NORFOLK 1, Norfolk Ridge, Introuvable Bank, stn DW1697, $24^{\circ} 39^{\prime} \mathrm{S}, 168^{\circ} 38^{\prime} \mathrm{E}, 569-616 \mathrm{~m}, 24$ June 2001, 1今, 1 ovig. ㅇ (MNHN-Na 15929); (ii) Norfolk Ridge, Antigonia Bank, stn CP 2122, $23^{\circ} 22^{\prime} \mathrm{S}, 168^{\circ} 00^{\prime} \mathrm{W}, 560-577 \mathrm{~m}, 1$ November 2003, 1o (MNHN-Na 15940).

\section{Distribution}

Type locality: New Caledonia. Previously recorded from Norfolk Ridge by Bruce (2005) from West Norfolk Ridge in the Tasman Sea. 
Periclimenes venustus Bruce, 1990

Periclimenes venustus Bruce 1990c, p 230-240, Figures 1-6, 7a, 8a; Chace and Bruce 1993, p 124; Li 2000, p 246, Figure 327; Davie 2002, p 333.

\section{Material examined}

New Caledonia: PLOUVEAL, stn DW1222, Loyalty Islands, Uvea Lagoon, $20^{\circ} 28^{\prime} \mathrm{S}$, $166^{\circ} 30^{\prime} \mathrm{E}, 15 \mathrm{~m}, 12$ September 1992, 1 \% (MNHN-Na 14871).

\section{Remarks}

Not previously reported from New Caledonia. The single specimen has both second pereiopods but lacks a rostrum, with an epigastric spine on the carapace.

\section{Distribution}

Type locality: Coral Bay, Port Essington, Northern Territory, Australia. Also known from Japan, Philippines, Indonesia, Papua New Guinea, Australia (Western Australia), and New Caledonia.

\section{Periclimenes sp.}

(Figure 31)

\section{Material examined}

La Réunion: $\mathrm{MD} 32$, stn $\mathrm{DS} 173,20^{\circ} 51.5^{\prime} \mathrm{S}, 55^{\circ} 36.8^{\prime} \mathrm{E}, 270 \mathrm{~m}, 8$ September 1982,1 q (MNHN-Na 14927).

\section{Description}

The single specimen, cl $2.7 \mathrm{~mm}$, unfortunately lacks both second pereiopods and the posterior part of the telson; right first pereiopod, third and fifth pereiopods detached. It is a small pontoniine shrimp with subcylindrical body form.

Carapace smooth, glabrous. The rostrum is long and slender, horizontal mostly and feebly upcurved distally, well exceeding the antennular peduncle and subequal to the postorbital carapace length, with a dentition of $1+6 / 5$, epigastric spine and dorsal rostral teeth are large, long, slender and acute, as are ventral teeth, except for minute distal tooth, epigastric spine with basal suture, situated at anterior 0.4 of carapace length, first dorsal tooth on carapace, second dorsal tooth at level of posterior orbital margin. Supraorbital spine absent; antennal spine long, slender, marginal, close to inferior orbital angle, distinctly exceeding inferior orbital angle; hepatic spine large, as long as antennal spine, more robust, at same level as antennal spine, below the level between epigastric spine and first dorsal rostral tooth.

Third abdominal segment with feebly dorsal prominence; sixth segment about 2.1 times length of fifth, subcylindrical, about 1.7 times longer than central depth, posterolateral angle acute, posteroventral angle rounded. 


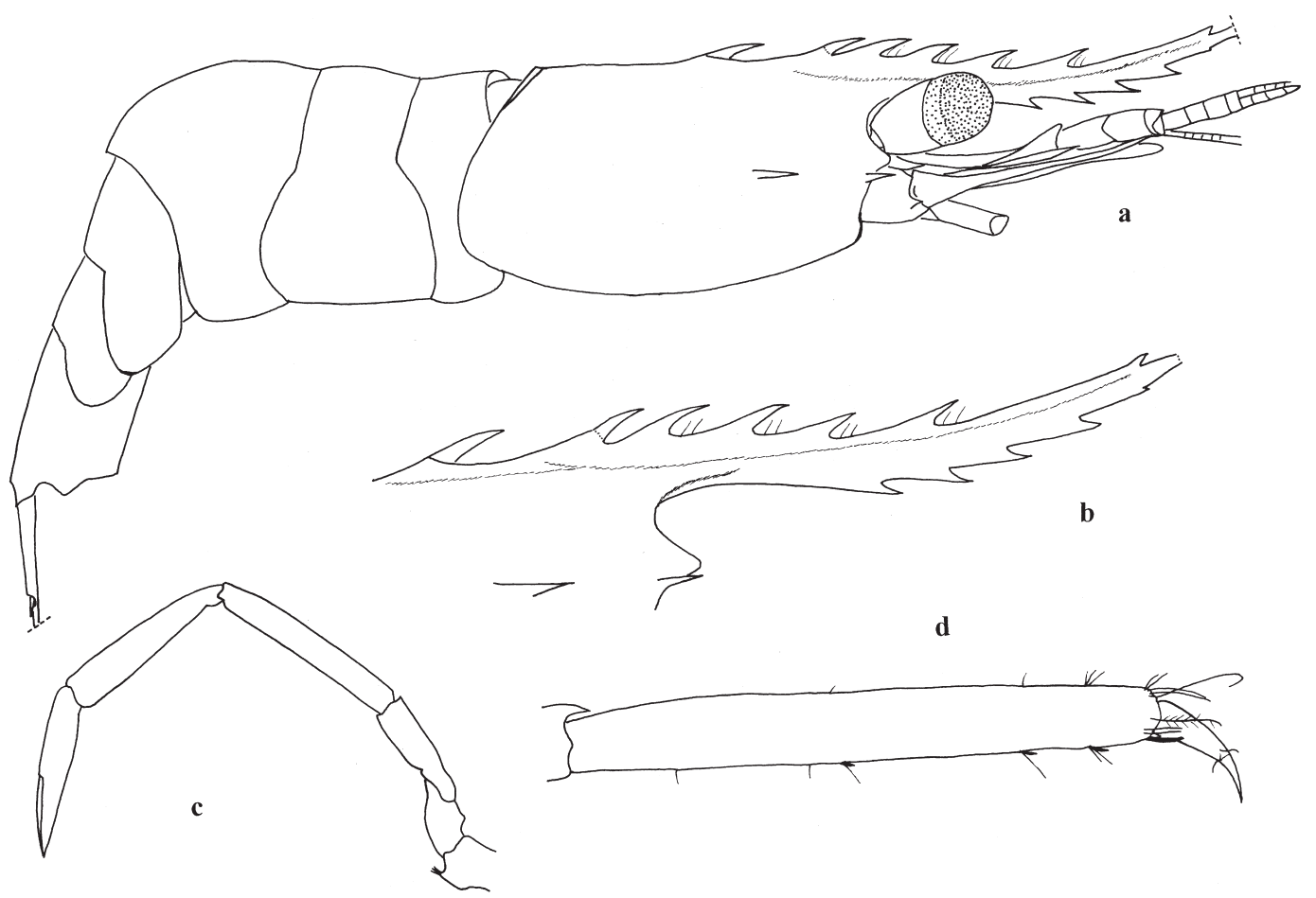

Figure 31. Periclimenes sp. 1, female (MNHN-Na 14927). (a) Body, lateral view; (b) rostrum; (c) first pereiopod; (d) same, propod and dactyl.

Eye well developed, with globular cornea, corneal diameter 0.18 of posterior orbital carapace length, feebly pigmented, without accessory pigment spot; stalk subcylindrical, slightly wider than cornea in dorsal view.

Antennular peduncle overreaching third ventral rostral tooth; upper flagellum biramous, with proximal four segments fused, shorter free ramus with four segments, with nine groups of aesthetascs. Antennal basicerite robust, with strong acute lateral tooth; scaphocerite exceeding antennular peduncle, reaching basal fourth ventral rostral tooth; lateral margin straight, distolateral tooth almost reaching distal end of lamella.

Epistome with well-developed rounded bosses.

Fourth thoracic sternite without slender median process, with broad shallow transverse plates, separated by deep median fissure, fifth sternite similar, transverse plates subequal to those of fourth; posterior sternites unarmed.

Mandible without palp; incisor process distally with three (right) or four (left) stout acute teeth, central teeth smaller than outer teeth. Third maxilliped reaching to basal carpocerite, coxa with arthrobranch distinct.

First pereiopods moderately slender, reaching distal end of scaphocerite, exceeding carpocerite by chela and half carpus. Ambulatory pereiopods robust, third pereiopod exceeds carpocerite by dactyl and distal two-thirds propod; dactyl compressed, long, slender, simple, unguis distinct; propods with long distoventral spine and three small 
ventral spinules. Uropod slender; protopodite with distolateral lobe broadly rounded; exopod with lateral border feebly convex, with small distal tooth, and larger mobile spine medially, diaeresis distinct.

\section{Remarks}

Although the peculiar rostrum, armature on carapace, epistome with well-developed rounded bosses, and the feebly dorsal prominence on third abdominal segment show that the present taxon is distinguishable from almost all of the members in the genus, it is difficult to present it as a new species as it lacks both second pereiopods and the posterior part of the telson. These deficiencies make its exact systematic position unclear. More material is necessary to decide its precise systematic position. The armature of rostrum and carapace, particularly the long and acute rostral teeth and the hepatic spine which is at same level as antennal spine, looks somewhat like that of P. latipollex Kemp, 1922. The present form can be easily distinguished from that species by the simple dactyls of ambulatory pereiopods and deeper rostrum (not rod-like, although shallow).

Philarius imperialis (Kubo, 1940)

Harpilius imperialis Kubo 1940a, p 1, Figures 1-3.

Philarius imperialis: Holthuis 1952a, p 15; Miyake and Fujino 1968, p 420, Figure 6; Bruce 1976b, p 482; Fransen 1994, p 132; Bruce and Coombes 1995, p 137; Li 1996, p 230, Figure 9; Li 1998, p 224; Li 2000, p 252, Figure 335; De Grave 2000, p 142.

\section{Material examined}

New Caledonia: (i) lagoon, Îlot Maitre, scuba, $5 \mathrm{~m}$, with coral, coll. C. Vadon, 13 September 1978, 1 ovig. 9 (abdomen damaged, tail-fan lost) (MNHN-Na 15848). Loyalty Islands: ATELIER LIFOU, Lifou, Santal Bay, (ii) opposite Ngoni beach, stn 1459, $20^{\circ} 47.0^{\prime} \mathrm{S}, 167^{\circ} 03.0^{\prime} \mathrm{E}, 55-80 \mathrm{~m}$, trawl, 5 and 13 November 2000,1 ovig. 9 (MNHN-Na 15542); (iii) in the region of Easo Point, stn $1465,20^{\circ} 47.7^{\prime} \mathrm{S}, 167^{\circ} 07.0^{\prime} \mathrm{E}, 35-45 \mathrm{~m}$, trawl, 16 November 2000, 1 ovig. ㅇ (MNHN-Na 15543).

Host

(i) Acropora sp. [Scleractinia].

Remarks

Not previously recorded from New Caledonia and Loyalty Islands.

\section{Distribution}

Type locality: Nankin-hama, Hahajima, Ogasawa Islands. Also known from Arabia, Israel, Kenya, Zanzibar, Tanzania, Seychelles, La Réunion, Singapore, Vietnam, China, Japan, Papua New Guinea, Australia (Western Australia, Northern Territory, Great Barrier Reef), Coral Sea, Caroline Islands, New Caledonia, Loyalty Islands, and Marshall Islands. 
Platycaris latirostris Holthuis, 1952

Platycaris latirostris Holthuis 1952a, p 173, Figures 85, 86; Barnard 1962, p 243; Bruce 1966c, p 1, Figures 1-5; Bruce 1976d, p 47, Figure 4; Bruce 1985b, p 5, Figures 4, 5; Li 2000, p 254, Figure 337.

Material examined

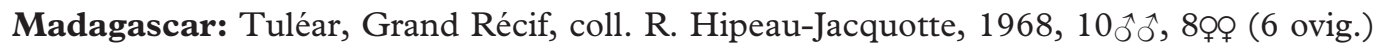
(MNHN-Na 15833).

Host

Galaxea sp. [Scleractinia].

Remarks

First recorded from Madagascar by Barnard (1962).

\section{Distribution}

Type locality: Indonesia. Also known from Zanzibar, Tanzania, Madagascar, Indonesia, Australia (Queensland), and Fiji.

Pliopontonia furtiva Bruce, 1973

Pliopontonia furtiva Bruce 1973a, p 99-108, Figures 1-5, Plate 1; Bruce 1991b, p 266; Chace and Bruce 1993, p 128; Li 2000, p 258, Figure 341; Davie 2002, p 336.

Material examined

New Caledonia: Canal Woodin, $15 \mathrm{~m}$, scuba, coll. Hamel, 19 November 1992, $1 \overbrace{}^{\lambda}$ (MNHN-Na 14929).

Host

Ricordia florida (Duchassaing and Michelotti, 1860) [Corallimorpharia, Anthozoa].

Remarks

Previously reported from New Caledonia in Atoll de Huon (Bruce, 1991b). The specimen has a rostral dentition of $7 / 0$ and has both second pereiopods: the ambulatory pereiopods are held in the dorsiflexed position as previously noted. The association with Ricordia represents a new host record.

\section{Distribution}

Type locality: Ras Iwatine, Kenya. Also known from the Seychelles, Japan, Philippines, Indonesia, Australia (Queensland, New South Wales), Solomon Islands, New Caledonia, and Marshall Islands. 
Pontoniopsis comanthi Borradaile, 1915

Pontoniopsis comanthi Borradaile 1915, p 213; Borradaile 1917, p 377, Plate 57, Figure 27; Holthuis 1952a, p 153-156, Figures 70, 71; Chace and Bruce 1993, p 130; Li 2000, p 276, Figure 369; Davie 2002, p 337.

Material examined

Philippines: (i) Maribago, Mactan Island, Cebu Province, $10^{\circ} 17^{\prime} \mathrm{N}, 124^{\circ} 00^{\prime} \mathrm{E}, 2-3 \mathrm{~m}$,

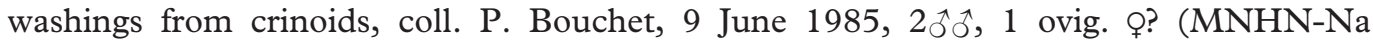
14930); (ii) same, 3-5 m, washings from mixed crinoids, $6 \hat{\jmath} \widehat{0}$, 5 ọ (3 ovig.) (MNHN-Na 14931). New Caledonia: (iii) Touho Bank, on crinoid, 1 ( $(M N H N-N a ~ 15843)$; (iv)

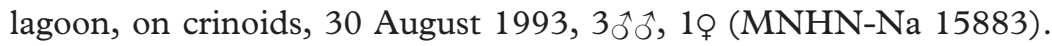

Hosts

(i) (ii) Comanthina schlegeli (P. H. Carpenter, 1881); (ii) also Comatella nigra (P. H. Carpenter, 1888), Comanter multibrachiata (P. H. Carpenter, 1888) Comanthus bennetti (J. Müller, 1841); det. A. M. Clark [Crinoides, Echinoderma].

\section{Parasites}

One specimen from (ii) has a hemiarthrinid parasite, Paraphrixus nigrocinctus (Chopra) [Bopyridae, Isopoda].

Remarks

Previously recorded from the Philippines, from Moalboal Island (Bruce 1989a). The specimens present no special features.

\section{Distribution}

Type locality: Mabuaig Island, Torres Strait. Also known from Israel, Red Sea, Kiribati, Kenya, Zanzibar, Seychelles, Japan, Philippines, Indonesia, Australia (Western Australia, Queensland), Coral Sea, Tasman Sea, Marianas Islands, Marshall Islands, and Fiji.

Thaumastocaris streptopus Kemp, 1922

Thaumastocaris streptopus Kemp 1922, p 244, Figures 78-80; Bruce 1991b, p 258, Figure 21; Bruce 1996, p 250-251, Figure 21; Li 2000, p 286, Figure 380.

\section{Material examined}

Chesterfield: (i) AMUSIUM 1, stn CC16, 2020' S, $160^{\circ} 48^{\prime} \mathrm{E}, 68-70 \mathrm{~m}, 6$ May 1998, 1 \% (MNHN-Na 15819). New Caledonia: Îlot Maitre, (ii) lagoon, scuba, $25 \mathrm{~m}$, with sponge, coll. C. Vadon, 5 September 1978, $1 \widehat{\jmath}$ (MNHN-Na 15837); (iii) Chenal of Îlot Maitre, scuba, $22 \mathrm{~m}$, with sponge, coll. C. Vadon, 3 October 1978, 1 ( (MNHN-Na 15859); (iv) $22^{\circ} 19.35^{\prime} \mathrm{S}, 166^{\circ} 25.85^{\prime} \mathrm{E}, 20 \mathrm{~m}$, scuba, with sponge, coll. I. Takeuchi, 10 November 1995 ,

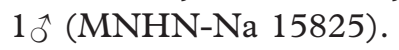

Remarks

The specimen of (i) has a carapace length $6.65 \mathrm{~mm}$, rostral formula is $9 / 3$, the first pereiopods are equal, the carpa six subsegmented; (ii) has a carapace length $3.59 \mathrm{~mm}$, rostral formula is $11 / 4$, the carpa of first pereiopods are equal but dissimilar, right with four subsegments, left with two subsegments, and right merus with two subsegments; (iii) has a 
carapace length $6.90 \mathrm{~mm}$, rostral formula is $9 / 3$, the first pereiopods are equal, with the carpa five-subsegmented and merus two-subsegmented; (iv) has a carapace length $7.43 \mathrm{~mm}$, rostral formula is $10 / 3$, the first pereiopods are equal, with the carpa fivesubsegmented.

\section{Distribution}

Type locality: New Caledonia. Also known from Jordan, Sudan, Somalia, Kenya, Zanzibar, Tanzania, Madagascar, Philippines, Indonesia, Australia (Queensland), Caroline Islands, Chesterfield Islands, New Caledonia, and Marshall Islands.

\section{Zenopontonia noverca (Kemp, 1922)}

Periclimenes (Periclimenes) noverca Kemp 1922, p 162-165, Figures 28-30.

Zenopontonia noverca: Bruce 1975a, p 277-280, Figure 1; Li 2000, p 307, Figure 408; Davie 2002, p 341.

\section{Material examined}

Madagascar: (i) Nosy Be' Tany Kely, $25 \mathrm{~m}$, photo, CD 25, coll. P. Laboute, 21

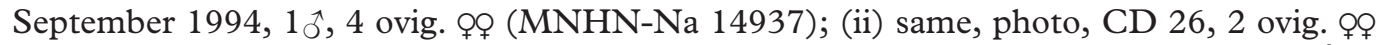
(MNHN-Na 14938). New Caledonia: (iii) lagoon, entre of Seiche croissant Reef and Îlot Maitre, scuba, $12 \mathrm{~m}$, with coral, coll. C. Vadon, 10 October 1978, 1 ovig. \& (MNHN-Na 15890); (iv) Nouméa (Anse Vata), 2 m, coll. Berthault, 1 May 2000, 1 ovig. @ (MNHN-Na 15892).

Hosts

(i) (ii) Pentaceraster sp. [Asteroides, Echinoderma]; (iii) Pocillopora sp. [Scleractinia].

\section{Remarks}

Previously reported from Madagascar, from Nosy Be, by Bruce (1975a, 1978a). (i) (ii) Five females have a rostral dentition of $8 / 0$, one has $10 / 0$, and the single male has $9 / 0$; (iii) rostral formula $7 / 1$. This species is usually associated with asteroids, so the association with Pocillopora is probably accidental.

\section{Distribution}

Type locality: New Caledonia. Also known from Zanzibar, Madagascar, Australia (Queensland), and New Caledonia.

\section{Summary}

By the studies of Bruce (1981a, 1983b, 1985a, 1990a, 1991a, 1991b, 1996) and the present paper, 48 genera 169 species of the superfamily Palaemonoidea have been reported based on the material deposited in the collections of the Muséum national d'Histoire naturelle, Paris, collected mainly from the Indo-Pacific areas. The appendix shows the geographical distribution of the 117 presently reported species. 


\section{Acknowledgements}

We are most grateful to Alain Crosnier for providing the opportunity to study the material and for the numerous improvements to the draft manuscript, and writing the French abstract. Special thanks are due to him from both authors for his kind assistance during their visits to Paris. Thanks are due to B. Richer de Forges, who was the main collector of the present research samples from the New Caledonia area. J. C. Markham kindly identified the bopyrid parasites, Régis Cleva helped to collect some references, both are also greatly appreciated. This study was partly supported by the National Natural Science Foundation of China (no. 40276044 (XL), and facilitated by support from the Australian Biological Resources Study (A.J.B.).

\section{References}

Alcock A. 1901. A descriptive catalogue of the Indian deep-sea Crustacea Decapoda Macrura and Anomala, in the Indian Museum. Being a revised account of the deep-sea species collected by the Royal Indian Marine Survey Ship Investigator. Calcutta: Trustees of the Indian Museum, 286 p, 3 plates.

Alcock A, Anderson AR. 1894. Natural history notes from H. M. Indian Marine Survey Steamer Investigator, Commander C. F. Oldham, R. N., commanding, Series II, 14: an account of a recent collection of deep sea Crustacea from the Bay of Bengal and Laccadive Sea. Journal of the Asiatic Society of Bengal 63:141-185. Plate 9.

Audouin V. 1825. Explication sommaire des planches de Crustacés de l'Égypte et de la Syrie, publiées par JulesCésar Savigny, membre de l'Institut: offrant un exposé des caractères naturels des genres avec la distinction des espèces. Description de l'Égypte ou recueil des observations et des recherches qui ont été faites en Égypte pendant l'expédition de l'armée francaise. Histoire Naturelle 1:77-98.

Balss H. 1913. Diagnosen neuer ostasiatischer Macruren. Zoologischer Anzeiger 42:234-239.

Balss H. 1914. Ostasiatische Decapoden II. Die Natantia und Reptantia. Abhandlunger der Bayerischen Akademie derWissenschaften Supplement 2:1-101. Figures 1-50, Plate 1.

Barnard KH. 1950. Descriptive catalogue of South African Decapoda Crustacea. Annals of the South African Museum 38:1-837. Figures 1-154.

Barnard KH. 1962. New records of marine Crustacea from the East African Region. Crustaceana 3:239-245. Figures 1-3.

Borradaile LA. 1898. A revision of the Pontoniidae. Annals and Magazine of Natural History, Series 7 2:376-391.

Borradaile LA. 1899. On the Stomatopoda and Macrura brought by Dr. Willey from the South Seas. In: Willey A, editor. Zoological results based on materials from New Britain, New Guinea, Loyalty Islands and elsewhere, collected during the years 1895, 1896 and 1897, part 4. Cambridge: Cambridge University Press. p 395-428. Plates 36-39.

Borradaile LA. 1915. Notes on Carides. Annals and Magazine of Natural History, Series 8 15:205-213.

Borradaile LA. 1917. The Percy Sladen Trust Expedition to the Indian Ocean in 1905, under the leadership of Mr. J. Stanley Gardiner, M. A., Vol. 6, VIII: On the Pontoniinae. The Transactions of the Linnean Society of London, (2)17:323-396, pls. 52-57.

Bray DM. 1976. A review of two Western Australian shrimps of the genus Palaemonetes, P. australis Dakin, 1915 and $P$. atrinubes sp. nov. (Decapoda, Palaemonidae). Record of the Western Australian Museum 4:65-84. Figures 1-42.

Bruce AJ. 1965. Notes on some Indo-Pacific Pontoniinae, X. Periclimenes cristimanus sp. nov., a new pontoniinid shrimp from Singapore. Annals and Magazine of Natural History, Series 13 8:487-493. Figures 1, 2.

Bruce AJ. 1966a. Notes on some Indo-Pacific Pontoniinae. XI. A re-examination of Philarius lophos Barnard, with the designation of a new genus Ischnopontonia. Bulletin of Marine Science 16:584-598. Figures 1-5.

Bruce AJ. 1966b. Periclimenes tosaensis Kubo. Notes on some Indo-Pacific Pontoniinae, I. Crustaceana 10:15-22. Figures $1-4$.

Bruce AJ. 1966c. Notes on some Indo-Pacific Pontoniinae, II. Platycaris latirostris Holthuis. Crustaceana 11:1-9. Figures 1-5.

Bruce AJ. 1967a. Notes on some Indo-Pacific Pontoniinae III-IX. Descriptions of some new genera and species from the Western Indian Ocean and the South China Sea. Zoologischen Verhandlingen, Leiden 87:1-73. Figures 1-29. 
Bruce AJ. 1967b. A report on some pontoniid shrimps from New Caledonia. (Crustacea Decapoda Natantia). Bulletin du Muséum National d'Histoire Naturelle, Paris, Série 2 39:1148-1171. Figures 1-10.

Bruce AJ. 1969a. Observations upon the host specificity and distribution of focaste japonica (Ortmann) and focaste lucina (Nobili) (Decapoda Natantia, Pontoniinae). Crustaceana 17:298-302. Figures 1, 2.

Bruce AJ. 1969b. Preliminary descriptions of sixteen new species of the genus Periclimenes Costa, 1844 (Crustacea, Decapoda Natantia, Pontoniinae). Zoologische Mededelingen, Leiden 43:253-278.

Bruce AJ. 1970a. Report on some commensal pontoniinid shrimps (Crustacea: Palaemonidae) associated with an Indo-Pacific gorgonian host (Coelenterata: Gorgonacea) Journal of Zoology, London 160:537-544. Figures 1-3.

Bruce AJ. 1970b. Notes on some Indo-Pacific Pontoniinae, XV. Hamopontonia corallicola gen. nov., sp. nov., a new pontoniinid shrimp from Hong Kong. Crustaceana 18:37-48. Figures 1-4.

Bruce AJ. 1970c. Observations on the Indo-West Pacific species of the genus Palaemonella Dana, 1852 (Decapoda, Pontoniinae). Crustaceana 19:273-287. Figures 1-7, Plate 1.

Bruce AJ. 1970d. On the identity of Periclimenes pusillus Rathbun, 1906 (Decapoda, Pontoniinae). Crustaceana 19:306-310. Figure 1.

Bruce AJ. 1971a. Palaemonella Dana and Periclimenes Costa. Pontoniinid shrimps from the ninth cruise of R/V Anton Bruun, IIOE, 1964, I. Smithsonian Contributions to Zoology 82:1-13. Figure 1.

Bruce AJ. 1971b. Periclimenes attenuatus sp. nov. (Crustacea, Decapoda, Natantia, Pontoniinae), a new commensal shrimp from the Duke of York Islands. Pacific Science 25:533-544. Figures 1-5.

Bruce AJ. 1972. Notes on Indo-Pacific Pontoniinae. XIX. Allopontonia iaini gen. nov., sp. nov., a new echinoid associate from Zanzibar (Decapoda, Caridea). Crustaceana 22:1-12. Figures 1-5.

Bruce AJ. 1973a. Notes on some Indo-Pacific Pontoniinae. XXII. Pliopontonia furtiva gen. nov., sp. nov., a new shrimp associated with a coralliomorph zooantharian. Crustaceana 24:97-109. Figures 1-5, Plate 1.

Bruce AJ. 1973b. Notes on some Indo-Pacific Pontoniinae. XXIV. Dasycaris zanzibarica sp. nov., from the western Indian Ocean, with remarks on other species of Dasycaris Kemp, 1922 (Decapoda, Natantia). Crustaceana 24:247-260. Figures 1-7.

Bruce AJ. 1974a. Coralliocaris viridis sp. nov., a preliminary note (Decapoda Natantia, Pontoniinae). Crustaceana 26:222-224.

Bruce AJ. 1974b. A report on a small collection of pontoniinid shrimps from the Island of Farquhar. Crustaceana 27:189-203. Figures 1-8.

Bruce AJ. 1975a. Notes on some Indo-Pacific Pontoniinae. XXV. Further observations upon Periclimenes noverca Kemp, with the designation of a new genus Zenopontonia, and some remarks upon Periclimenes parasiticus Borradaile. Crustaceana 28:275-285. Figures 1-3.

Bruce AJ. 1975b. Notes on some Indo-Pacific Pontoniinae. XXVI. Neoanchistus cardiodytes gen. nov., sp. nov., a new mollusc-associated shrimp from Madagascar (Decapoda, Palaemonidae) Crustaceana 29:149-165. Figures 1-7.

Bruce AJ. 1975c. Further observations on the Indo-West Pacific species of the genus Palaemonella Dana, 1852 (Decapoda Natantia, Pontoniinae). Crustaceana 29:169-185. Figures 1-7.

Bruce AJ. 1976a. A report on some pontoniinid shrimps collected from the Seychelles Islands by the F. R. V. Manihine, 1972, with a review of the Seychelles pontoniinid shrimp fauna. Zoological Journal of the Linnean Society 59:89-153. Figures 1-30.

Bruce AJ. 1976b. A synopsis of the pontoniinid shrimp fauna of Central East Africa. Journal of the Marine Biological Association of India 16:462-490.

Bruce AJ. 1976c. Periclimenes soror Nobili, a pontoniinid shrimp new to the American fauna, with observations on its Indo-West Pacific distribution. Téthys 8:299-306. Figures 1-6.

Bruce AJ. 1976d. Shrimps and prawns of coral reefs, with special reference to commensalism. In: Jones O, Endean R, editors. Biology and geology of coral. New York: Academic Press, Inc. Volume 3, Biology 2, 37-94. Figures 1-21, Table 1.

Bruce AJ. 1977a. The possible identity of Coralliocaris macrophthalma (H. Milne-Edwards, 1837) Decapoda Natantia, Pontoniinae. Crustaceana 32:203-205. Figure 1.

Bruce AJ. 1977b. A report on a small collection of pontoniinid shrimps from Queensland, Australia. Crustaceana 33:167-181. Figures 1-10.

Bruce AJ. 1977c. Notes on some Indo-Pacific Pontoniinae, XXX. Some Periclimenes species from Madagascar (Decapoda Caridea). Crustaceana 33:265-274. Figures 1-5.

Bruce AJ. 1977d. Periclimenes kororensis sp. nov., an unusual shrimp associate of the fungiid coral Heliofungia actiniformis. Micronesica 13:33-43. Figures 1-4.

Bruce AJ. 1978a. A report on a collection of pontoniine shrimps from Madagascar and adjacent seas. Zoological Journal of the Linnean Society 62:205-290. Figures 1-44. 
Bruce AJ. 1978b. The re-examination of some pontoniine shrimp types first described by L. A. Borradaile. Crustaceana 34:251-268. Figures 1-9.

Bruce AJ. 1979a. Records of some pontoniine shrimps from the South China Sea. Cahiers de l'Indo-Pacifique $1: 215-248$.

Bruce AJ. 1979b. Periclimenes magnificus sp. nov., a coelenterate associate from the Capricorn Islands (Decapoda, Palaemonidae). Notes on some Indo-Pacific Pontoniinae, XXXI. Crustaceana Supplement 5:195-208. Figures 1-6, Plate 1.

Bruce AJ. 1980a. Some pontoniine shrimps from the Solomon Islands. Micronesica 16:261-269. Figures 1, 2.

Bruce AJ. 1980b. On some pontoniine shrimps from Nounéa, New Caledonia. Cahiers de l'Indo-Paficique 2:1-39. Figures 1-14.

Bruce AJ. 1981a. Decapod Crustacea: Pontoniinae. In: Résultats des Campagnes MUSORSTOM, I: Philippines (18-28 Mars 1976). Mémoires ORSTOM 91:189-215. Figures 1-18.

Bruce AJ. 1981b. Pontoniine shrimps from Viti Levu, Fijian Islands. Micronesica 17:77-95. Figures 1-11.

Bruce AJ. 1982. The pontoniine shrimp fauna of Hong Kong. In: Morton BS, Tseng CK, editors, Proceedings of the First International Marine Biological Workshop: The Marine Flora and Fauna of Hong Kong and Southern China, Hong Kong, 1980. Hong Kong: Hong Kong University Press. p 233-284. Figures 1-26.

Bruce AJ. 1983a. Additions to the marine fauna of the Northern Territory. 1. Decapod Crustacea: Caridea and Stenopodidea. The Beagle, Occasional Papers of the Northern Territory, Museum of Arts and Sciences $1: 41-49$.

Bruce AJ. 1983b. Expédition Rumphius II (1975). Crustacés parasites, commensaux, etc. IX: Crustacés Décapodes (1ére partie: Natantia Pontoniinae). Bulletin du Muséum National d'Histoire Naturelle, Paris, Série 4 5A:871-902. Figures 1-10.

Bruce AJ. 1983c. A note on the pontoniine shrimp fauna of La Réunion. Bulletin of Marine Science 33:165-166.

Bruce AJ. 1983d. The pontoniine shrimps fauna of Australia. Memoirs of the Australian Museum 18:195-218.

Bruce AJ. 1985a. Decapod Crustacea: Pontoniinae (MUSORSTOM II). In: Résultats des Campagnes MUSORSTOM, I et II. Philippines, Tome 2. Mémoires du Muséum National d'Histoire Naturelle 133:229-260. Figures 1-17.

Bruce AJ. 1985b. Some caridean associates of scleractinian corals in the Ryukyu Islands. Galaxea 4:1-21. Figures 1-12, Plate 1.

Bruce AJ. 1987. Notes on some Indo-Pacific Pontoniinae, XLIV. Periclimenes darwiniensis sp. nov., from the Northern Territory, Australia (Decapoda, Caridea) Crustaceana 52:29-39. Figures 1-5.

Bruce AJ. 1988a. A new palaemonid shrimp from the Zostera-beds of Moreton Bay, Queensland, Australia (Decapoda: Palaemonidae). The Beagle, Records of the Northern Territory Museum of Arts and Sciences 5:105-114. Figures 1-5.

Bruce AJ. 1988b. The occurrence of Palaemonetes atrinubes Bray (Crustacea: Decapoda: Palaemonidae) on the Australian east coast. The Beagle, Records of the Northern Territory Museum of Arts and Sciences 5:115-117. Figure 1.

Bruce AJ. 1988c. The shrimp fauna of a small tropical reef, the East Point Fish Reserve, Darwin. In: Larson HK, Michie MG, Hanley JR, editors. Darwin Harbour, proceedings of the workshop on Research and Management held in Darwin, 2-3 September, 1987, ANU North Australia Research Unit, Mangrove Monograph 4:226-245. Figure 1.

Bruce AJ. 1989a. A report on some coral reef shrimps from the Philippine Islands. Asian Marine Biology 6:173-192. Figures 1-6.

Bruce AJ. 1989b. Notes on some Indo-Pacific Pontoniinae, XLV. Conchodytes maculatus sp. nov., a new bivalve associate from the Australian Northwest Shelf. Crustaceana 56:182-192. Figures 1-6.

Bruce AJ. 1990a. Crustacea Decapoda: deep-sea palaemonoid shrimps from New Caledonian waters. In: Crosnier A, editor. Résultats des Campagnes MUSORSTOM. Volume 6, Mémoires du Muséum National d'Histoire Naturelle, A, Zoologie 145:149-215. Figures 1-39.

Bruce AJ. 1990b. Periclimenes franklini sp. nov., a new deep-sea shrimp from the Coral Sea. The Beagle, Occasional Papers of the Northern Territory Museum of Arts and Sciences 7:55-64.

Bruce AJ. 1990c. A new cnidarian-associated palaemonid shrimp from Port Essington, Cobourg Peninsula, Australia. Indo-Malayan Zoology 6(1989):229-243. Figures 1-8.

Bruce AJ. 1991a. Crustacea Decapoda: further deep-sea palaemonid shrimps from New Caledonian waters. In: Crosnier A, editor. Résultats des Campagnes MUSORSTOM. Volume 9, Mémoires du Muséum National d'Histoire Naturelle, Série A, Zoologie 152:299-411. Figures 1-75.

Bruce AJ. 1991b. Shallow-water palaemonoid shrimps from New Caledonia (Crustacea: Decapoda). In: Richer de Forges B, editor. Le benthos des fonds meubles des lagons de Nouvelle-Calédonie, 1. Études et Thèses. Paris: ORSTOM. 211-279. Figures 1-31. 
Bruce AJ. 1992. Two new species of Periclimenes (Crustacea: Decapoda: Palaemonidae) from Lizard Island, Queensland, with notes on some related taxa. Records of the Australian Museum 44:45-84. Figures 1-27.

Bruce AJ. 1994. A synopsis of the Indo-West Pacific genera of the Pontoniinae (Crustacea: Decapoda: Palaemonidae). Königstein: Koeltz Scientific Books. 172 p.

Bruce AJ. 1995. A re-examination of Palaemonetes sinensis (Sollaud, 1911) (Crustacea: Decapoda: Palaemonidae). The Beagle, Records of the Museums and Art Galleries of the Northern Territories 11:1-7. Figures 1-3.

Bruce AJ. 1996. Crustacea Decapoda: palaemonid shrimps from the Indo-West Pacific region, mainly from New Caledonia. In: Crosnier A, editor. Résultats des Campagnes MUSORSTOM, 15. Mémoires du Muséum National d'Histoire Naturelle 168:197-267. Figures 1-31.

Bruce AJ. 1998. New keys for the identification of Indo-West Pacific coral associated pontoniine shrimps, with observations on their ecology [Crustacea: Decapoda: Palaemonidae]. Ophelia 49:29-46.

Bruce AJ. 2002a. Leander manningi, a new palaemonine shrimp from Western Australia (Crustacea, Decapoda, Palaemonidae), with a review of the Indo-West Pacific species of the genus Leander E. Desmarest, 1849. Records of the Western Australian Museum 21:71-81. Figures 1-6.

Bruce AJ. 2002b. Notes on some Indo-Pacific Pontoniinae, XLVI. Palaemonella foresti sp. nov., a new pontoniine shrimp from Western Australia (Decapoda, Palaemonidae), with a review of the Indo-West Pacific species of the genus Palaemonella Dana, 1852. Crustaceana 75:277-298. Figures 1-4.

Bruce AJ. 2003. The pontoniine shrimp fauna of Hong Kong and the South China Sea (Crustacea: Decapoda: Palaemonidae). In: Morton B, editor. Perspectives on marine environment change in Hong Kong and southern China, 1977-2001. Proceedings of an international workshop reunion conference, Hong Kong, 2126 October 2001, Hong Kong: Hong Kong University Press. p 209-257. Table 1.

Bruce AJ. 2004. A partial revision of the genus Periclimenes Costa, 1884 (Crustacea: Decapoda: Palaemonidae). Zootaxa 582:1-26.

Bruce AJ. 2005. Pontoniine shrimps from the 2003 NORFANZ Expedition, 10 May-16 June [Crustacea: Decapoda: Palaemonidae]. Zootaxa 981:1-20. Figures 1-8.

Bruce AJ, Coombes KE. 1995. The palaemonoid shrimp fauna (Crustacea: Decapoda: Caridea) of the Cobourg Peninsula, Northern Territory. The Beagle, Occasional Papers of the Northern Territory, Museum of Arts and Sciences 12:101-144. Figures 1-12.

Bruce AJ, Okuno J, Li X. 2005. Manipontonia gen. nov., a new pontoniine shrimp genus for Periclimenes psamathe (De Man) [Crustacea: Decapoda: Palaemonidae]. Zootaxa 926:1-11. Figures 1-3.

Bruce AJ, Svoboda A. 1984. A report on a small collection of coelenterate associated pontoniine shrimps from Cebu, Philippine Islands. Asian Marine Biology 1:87-99. Figures 1-7.

Bruce AJ, Zmarzly DL. 1983. Periclimenes pilipes, new species, a crinoid associate from Eniwetak Atoll, Marshall Islands [Crustacea: Decapoda: Pontoniinae]. Journal of Crustacean Biology 3:644-654. Figures 1-6.

Chace FA Jr, Bruce AJ. 1993. The caridean shrimps (Crustacea: Decapoda) of the Albatross Philippine Expedition 1907-1910, part 6: Superfamily Palaemonoidea. Smithsonian Contributions to Zoology 543:1-152. Figures 1-23.

Dana JD. 1852. Conspectus of the Crustacea of the exploring expedition under Capt. C. Wilkes U. S. N. Proceedings of the Academy of Natural Sciences of Philadelphia 1852:10-28.

Davie PJF. 2002. Crustacea: Malacostraca: Phyllocarida, Hoplocarida, Eucarida (part 1). In: Wells A, Houston WWK, editors. Zoological catalogue of Australia. Volume 19.3A. Melbourne: CRIRO Publishing. 551 p.

De Grave S. 2000. Caridean shrimps (Crustacea, Decapoda) from Hansa Bay, Papua New Guinea: Palaemonidae and Gnathophyllidae. Bulletin de l'Institut Royal des Sciences Naturelles de Belgique, Biologie 70:119-148.

De Man JG. 1888. Report on the podophthalmous Crustacea of the Mergui Archipelago collected for the Trustees of Indian Museum Calcutta by John Anderson F. R. S. Superintendent of the Museum. Journal of the Linnean Society of London 22:1-312. Plates 1-19.

De Man JG. 1902. Die von Herrn Professor Kükenthal in Indischen Archipel gesammelten Dekapoden und Stomatopoden. In: Kükenthal W, editor. Ergebnisse einer zoologischen Forschungsreise in den Molukken un Borneo, Abhandlungen der Senckenbergischen und Naturforschenden Gesellschaft 25:467-929. Plates 19-27.

Debelius H. 1999. Crustacea, guide of the world. Frankfurt: IKAN-Unterwasserarchiv. $321 \mathrm{p}$.

Duris Z, Bruce AJ. 1995. A revision of the "petitthouarsii" species-group of the genus Periclimenes Costa, 1844 (Crustacea: Decapoda: Palaemondae). Journal of Natural History 29:619-671. Figures 1-22.

Forskål P. 1775. Descriptiones Animalium, Avium, Amphibiorum, Piscium, Insectorum, Vermium; quae in Itinere Orientali Observavit. Haunia: Heineck et Faber. 164 p.

Fransen CHJM. 1987. Notes on caridean shrimps of Easter Island with descriptions of three new species. Zoologische Mededelingen, Leiden 61:501-531. Figures 1-16. 
Fransen CHJM. 1989. Notes on caridean shrimps collected during the Snellius-II Expedition, I: associates of Anthozoa. Netherlands Journal of Sea Research 23:131-147. Figure 1-9.

Fransen CHJM. 1994. Marine palaemonoid shrimps of the Netherlands Seychelles Expedition 1992-1993. Zoologische Verhandelingen, Leiden 297:85-152. Figures 1-112, Plates 1-4.

Fujino T, Miyake S. 1969. On two new species of Palaemonid shrimps from Tanabe Bay, Kii Peninsula, Japan (Crustacea, Decapoda, Palaemonidae). Publications of the Seto Marine Biological Laboratory 17:143-154. Figures 1-5.

Fujino T, Miyake S. 1970. Caridean and stenopodidean shrimps from the East China and the Yellow Seas (Crustacea, Decapoda, Natantia). Journal of the Faculty of Agriculture, Kyushu University 16:237-312. Figures 1-25.

Gordon I. 1935. On new and imperfectly known species of Crustacea Macrura. Journal of the Linnean Society of London 39:307-351. Figures 1-27.

Guérin-Méneville FE. 1838. Crustacés, Arachnides et Insectes. In: Duperrey LJ, Voyage ahthor du monde, exécuté par Ordre du Roi, sur la Corvette de Sa Majesté, La Coquille, pendant les années 1822, 1823, 1824 et 1825. Zoologie 2 (no. 2, sect. 1): 1-47 (Crustacés), 48-319 (Arachnides et Insectes); plates (1-5 (Crustacés), 1-21 (Insectes). Paris: Arthus Bertrand.

Guérin-Méneville FE. 1855. Crustaceos. In: La Sagra: Historia Fisica Politica y Natural de la Isla de Cuba, Historia Natural. Volume 7 (atlas). Paris: Arthus Bertrand. 88 p, 3 plates.

Hayashi K. 1986. Shrimps. In: Baba K, Hayashi K, Toriyama M, editors. Decapod crustaceans from continental shelf and slope around Japan. Tokyo: Tosho Printing Co. Ltd.. p 335. 22 text-figures, 176 photographs.

Heller C. 1861. Synopsis der in rothen Meere vorkommenden Crustaceen. Verhandlungen des Kaiserlichköniglichen Zoologisch-Botanischen Gesellschaft in Wien 11:3-32.

Henderson JR. 1893. A contribution to Indian carcinology. Transactions of the Linnean Society of London, Series 2 5:325-458. Plates 36-40.

Hipeau-Jacquotte R. 1973. Étude des crevettes Pontoniinae (Palaemonidae) associées aux mollusques Pinnidae à Tuléar (Madagascar). 3. Morphologie externe et morphologie des piéces buccales. Téthys Supplément 1973:95-116.

Hipeau-Jacquotte R. 1974. Étude des crevettes Pontoniinae (Palaemonidae) associées aux molluscs Pinnidae à Tuléar (Madagascar). 6. Comportement sexuel. Téthys 5:403-408. Figure 1.

Holthuis LB. 1950. The Decapoda of the Siboga Expedition, part X: the Palaemonidae collected by the Siboga and Snellius Expeditions, with remarks on other species, part I: Subfamily Palaemoninae. Siboga-Expeditie 39a:1-268. Figures 1-52.

Holthuis LB. 1951. The Subfamilies Euryrhynchinae and Pontoniinae. A general revision of the Palaemonidae (Crustacea Decapoda Natantia) of the Americas. II. Allan Hancock Foundation Publication, Occasional Paper 11:1-332. Plates 1-63.

Holthuis LB. 1952a. The Decapoda of the Siboga Expedition, part XI: the Palaemonidae collected by the Siboga and Snellius Expeditions, with remarks on other species, part II: Subfamily Pontoniinae. Siboga-Expeditie 39a:1-254. Figures 1-110.

Holthuis LB. 1952b. The subfamily Palaemoninae, part II. A general revision of the Palaemonidae (Crustacea Decapoda Natantia) of the Americas. Allan Hancock Foundation Occasional Papers 12:1-396. Figure 1, Plates 1-55.

Holthuis LB. 1958. Contributions to the knowledge of the Red Sea, 8. Crustacea Decapoda from the northern Red Sea (Gulf of Aqaba and Sinai Peninsula). I. Macrura. Bulletin of the Sea Fisheries Research Station (Haifa, Israel) $17: 1-40$. Figures 1-15.

Holthuis LB. 1959. Results of the re-examination of the type specimens of some species belonging to the subfamilies Pontoniinae and Palaemoninae (Crustacea Decapoda Macrura). Zoologische Mededelingen, Leiden 36:193-200. Figure 1.

Holthuis LB. 1980. Shrimps and prawns of the world. An annotated catalogue of species of interest to fisheries. FAO Fisheries Synopsis 125:i-xvii, 1-231.

Jacquotte R. 1963. Habitat electif des Pontoniinae commensales des Pinnidae de Tulear (Madagascar). Recueil des Travaux de la Station Marine d'Endoume 29:60-62. Figure 1.

Kemp S. 1922. Notes on Crustacea Decapoda in the Indian Museum, XV: Pontoniinae. Records of the Indian Museum 24:113-288. Figures 1-105, Plates 3-9.

Kemp S. 1925. Notes on Crustacea Decapoda in the Indian Museum, XVII: on various Caridea. Records of the Indian Museum 27:249-343. Figures 1-24.

Kingsley JS. 1878. List of the North American Crustacea belonging to the sub-order Caridea. Bulletin of the Essex Institute 10:53-71.

Kubo I. 1940a. A new shrimp, Harpilius imperialis. Journal of the Imperial Fisheries Institute 34:1-4. Figures 1-3. 
Kubo I. 1940b. Studies on Japanese palaemonoid shrimps, II: Pontoniinae. Journal of the Imperial Fisheries Institute 34:31-75. Figures 1-36.

Kubo I. 1951. Some macrurous decapod Crustacea found in Japanese waters, with descriptions of four new species. Journal of the Tokyo University of Fisheries 38:259-289. Figures 1-16.

Ledoyer M. 1984. Les Caridea (Crustacea: Decapoda) des herbiers de Phanérogames marines de NouvelleCalédonie (Région de Nouméa). Zoologische Verhandelingen, Leiden 211:1-58. Figures 1-21, Tables 1-5.

Li X. 1996. The pontoniine shrimps from Nansha Islands, China. I. Marine Fauna and Flora and Biogeography of the Nansha Islands and Neighbouring Waters 2:222-233. Figures 1-9.

Li X. 1997. Report on Gnathophyllidae and Pontoniinae (Decapoda, Palaemonoidea) shrimps from the Xisha Islands and adjacent waters, South China Sea. Studia Marina Sinica (Qingdao) 38:223-251. Figures 1-12.

Li X. 1998. The pontoniine shrimps (Crustacea: Caridea: Palaemonoidea) from Nansha Islands, South China Sea. II. Studies on Marine Fauna and Flora and Biogeography of the Nansha Islands and Neighbouring Waters 3:218-226. Figures 1-9.

Li X. 2000. Catalog of the genera and species of Pontoniinae Kingsley, 1878. Beijing: Xueyuan Press. 319.408 figures.

Li X. 2001. On some pontoniine shrimps (Crustacea: Caridea) from Hainan Island, South China Sea. In: Matsuura K, editor. Marine fauna of the shallow waters around Hainan Island, South China Sea. National Science Museum Monographs 21:75-86.

Li X. 2004a. The pontoniine shrimps (Crustacea, Decapoda, Palaemonidae) from Anambas and Natuna Islands, Indonesia, collected by Anambas Expedition, 2002. The Raffles Bulletin of Zoology Supplement 11:67-72. Figures 1, 2 .

Li X. 2004b. Report on some pandalid and pontoniine shrimps from the Chinese Seas (Crustacea, Decapoda, Caridea). Acta Zootaxonomica Sinica 29:820-826. Figures 1-9.

Li X, Bruce AJ, Manning RB. 2004. Some palaemonid shrimps (Crustacea: Decapoda) from Northern South China Sea, with descriptions of two new species. The Raffles Bulletin of Zoology 52:513-553. Figures 1-33.

Li X, Liu JY. 2002. Report of pontoniine shrimps (Crustacea: Decapoda) collected by the joint Chinese-German marine biology expeditions to Hainan Island, South China Sea. I. Anchistus, Conchodytes, Coralliocaris. Chinese Journal of Oceanology and Limnology 20:371-377. Figures 1-4.

Li X, Liu JY. 2003. Report of pontoniine shrimps (Crustacea: Decapoda) collected by the joint Chinese-German marine biology expeditions to Hainan Island, South China Sea. II. Harpiliopsis, Ischnopontonia, focaste, Palaemonella, Periclimenaeus, Periclimenella. Chinese Journal of Oceanology and Limnology 21:154-165. Figures 1-8.

Li X, Liu JY. 2004. Report of pontoniine shrimps (Crustacea: Decapoda) collected by the joint Chinese-German marine biology expeditions to Hainan Island, South China Sea. III. Periclimenes. Chinese Journal of Oceanology and Limnology 22:89-100. Figures 1-8.

Lucas H. 1846. Crustacés, Arachnides, Myriapodes et Hexapodes. Exploration Scientifique de l'Algérie pendant les années 1840, 1841, 1842. Sciences physiques. Zoologie I, Histoire Naturelle des Animaux Articulés 1:1-403. Plates 1-8.

Marin IN, Britayev TA, Anker A. 2004. Pontoniine shrimps associated with cnidarians: new records and list of species from coastal waters of Viet Nam. Arthropoda Selecta 13:199-218. Figures 1-13.

Markham JC. 1989. Three species of Isopoda Bopyridae new to the fauna of the Philippines. The Beagle, Records of the Northern Territory Museum of Arts and Sciences 6:141-148.

Miers EJ. 1884. Crustacea. In: Report of the zoological collections made in the Indo-Pacific Ocean during the voyage of H.M.S. “Alert” 1881-2. London: British Museum (Natural History). p 178-322, 513-575. Plates $18-35,46-52$.

Milne Edwards H. 1837. Histoire naturelle des Crustacés, comprenant l'anatomie, la physiologie et la classification de ces animaux. Volume 2. Paris: Roret. 532 p.

Minemizu R, Okuno J, Takeda M. 2000. Marine decapod and stomatopod crustaceans mainly from Japan. Tokyo: Bun-Ichi Sogo Shuppan Co.. 344 p.

Mitsuhashi M. 2000. A revision of the genus Coralliocaris Stimpson, 1860 (Crustacea: Decapoda: Palaemonidae) from Japan. IOP Diving News 11:2-7. Figures 1-11.

Miyake S, Fujino T. 1968. Pontoniinid shrimps from the Palau Islands (Crustacea, Decapoda, Palaemonidae). Journal of the Faculty of Agriculture, Kyushu University 14:399-431. Figures 1-8.

Monod T. 1976. Sur une nouvelle collection de Crustracés Décapodes de Nouméa (Nouvelle-Calédonie). Cahiers du Pacifique 19:133-152. Figures 1-82.

Nobili G. 1901. Decapodi e Stomatopodi Eritrei del Museo Zoologico dell’Universita di Napoli. Annuario del Museo Zoologico della R. Universita di Napoli, New Series 1:1-20. 
Nobili G. 1904. Diagnoses préliminaires de vingt-huit espèces nouvelles de Stomatopodes et Décapodes Macroures de la mer Rouge. Bulletin de Muséum d'Histoire Naturelle, Paris 10:228-238.

Nobili G. 1906a. Diagnoses préliminaires de Crustacés. Décapodes et Isopodes nouveaux recueillis par M. le Dr. G. Seurat aux Îles Touamotou. Bulletin du Muséum d'Histoire Naturelle 12:256-270.

Nobili G. 1906b. Crustacés Décapodes et Stomatopodes: Mission J. Bonnier et Ch. Perez (Golfe Persique 1901). Bulletin Scientifique de la France et de la Belgique 40:13-159. Figures 1-3, Plates 2-7.

Nobili G. 1907. Ricerche sui Crostacei della Polinesia. Decapodi, Stomatopodi, Anisopodi e Isopodi. Memorie della Reale Accademia della Scienze di Torino, Serie 2 57:351-430. Plates 1-3.

Okuno J. 1999. Palaemonella hachijo, a new species of shrimp (Crustacea: Decapoda: Palaemonidae) from a submarine cave in southern Japan. Proceedings of the Biological Society of Washington 112:739-745. Figures 1-3.

Okuno J. 2000. Additional specimens of Palaemonella hachijo Okuno, 1999 (Decapoda, Caridea, Palaemonidae). Crustaceana 73:1297-1299. Figure 1.

Ortmann AE. 1890. Die Unterordnung Natantia Boas. Die Decapoden-Krebse des Strassburger Museums, mit besonderer Berucksichtigung der von Herrn Dr. Döderlein bei Japan und bei der Liu-Kiu-Inseln gesammelten und z. Z. in Strassburger Museum aufbewahrten Formen, I. Zoologische Jahrbucher Abteilung für Systematik, Geographie und Biologie der Thiere 5:437-542. Plates 36, 37.

Patton WK. 1966. Decapod Crustacea commensal with Queensland branching corals. Crustaceana 10:271-295. Figures 1-3.

Paulson O. 1875. Investigations on the Crustacea of the Red Sea with notes on Crustacea of the adjacent seas. Part I. Podophthalmata and Edriophthalmata (Cumacea). Kiev: SV Kul'zhenko, 144 p. 21 plates.

Peters W. 1852. Conchodytes, eine neue in Muscheln lebende Gattung von Garneelen. Berichte über die zur Bekanntmachung geeigneten Verhandlungen der K. Preuss. Akademie der Wissenschaften zu Berlin 1852:588-595.

Rathbun MJ. 1906. The Brachyura and Macrura of the Hawaiian Islands. Bulletin of the United States Fish Commission (1903) 23:827-930. Plates 1-24.

Say T. 1817-18. An account of the Crustacea of the United States. Journal of the Academy of Natural Sciences of Philadelphia 1(1817):57-80, 97-101, 151-169, Plate 4; (1818):235-253, 313-319, 374-401, 423, 441, 445-458.

Schenkel E. 1902. Beitrag zur Kenntnis der Dekapondenfauna von Celebes. Verhhandlungen der Naturforschenden Gesellschaft in Basel 13:485-585. Plates 7-13.

Stimpson W. 1860. Prodromus descriptionis animalium evertebratorum, quae in expeditione ad Oceanum Pacificum septentrionalem, a Republica Federata missa Cadwaladaro Ringgold et Johanne Rodgers Ducibus, observavit et descripsit. Proceedings of the Academy of Natural Sciences of Philadelphia 1860:22-48.

Wicksten MK, Hendrickx ME. 1985. New records of caridean shrimps in the Gulf of California, Mexico. Proceedings of the Biological Society of Washington 98:571-573.

Yokoya Y. 1936. Some rare and new species of decapod crustaceans found in the vicinity of the Misaki Marine Biological Station. Japanese Journal of Zoology 7:129-146. Figures 1-4.

Zehntner L. 1894. Crustacés de l'Archipel Malais. Voyage de MM. M. Bedot et C. Pictet dans l'Archipel Malais. Revue Suisse de Zoologie et Annales du Musée d'Histoire Naturelle de Genève 2:135-214. Plates 7-9. 
Appendix. Geographical distribution of presently reported species

\begin{tabular}{|c|c|c|c|c|c|c|c|c|c|c|c|c|c|}
\hline & 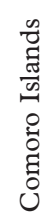 & 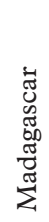 & 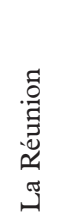 & 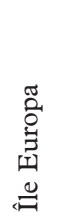 & 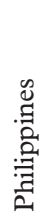 & 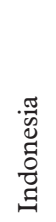 & 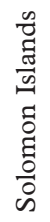 & $\begin{array}{l}\vec{Z} \\
\stackrel{\sigma}{\Xi} \\
\vec{\Xi} \\
\stackrel{\sigma}{\nu}\end{array}$ & 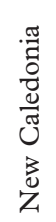 & 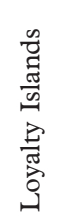 & 涪 & $\begin{array}{l}\vec{z} \\
\frac{\vec{\pi}}{5} \\
\vec{E}\end{array}$ & 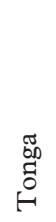 \\
\hline \multicolumn{14}{|l|}{ ANCHISTIOIDIDAE } \\
\hline Anchistioides willeyi & + & + & & & + & & & & + & & + & & \\
\hline \multicolumn{14}{|l|}{ GNATHOPHYLLIDAE } \\
\hline Gnathophyllum americanum & & & & & & & & & + & + & & & \\
\hline \multicolumn{14}{|l|}{ PALAEMONIDAE } \\
\hline \multicolumn{14}{|l|}{ PALAEMONINAE } \\
\hline Brachycarpus biunguiculatus & & & + & & & & & & + & & & & \\
\hline Leander tenuicornis & & & & & & & & & + & + & & & \\
\hline Macrobrachium australe & & & & & & & & & + & & & & \\
\hline Macrobrachium equidens & & & & & & & & & + & & & & \\
\hline Nematopalaemon tenuipes & & + & & & & + & & & & & & & \\
\hline Palaemon debilis & & & & + & & & & & + & & & & \\
\hline Palaemonetes atrinubes & & & & & & & & & + & & & & \\
\hline Urocaridella antonbruunii & & & + & & & & & & + & & & & \\
\hline Urocaridella urocaridella & & & & & + & & + & & + & & & & \\
\hline \multicolumn{14}{|l|}{ PONTONIINAE } \\
\hline Allopontonia iaini & & & & & & & & & + & & & & \\
\hline Altopontonia disparostris & & & & & & & & & & & + & & \\
\hline Amphipontonia kanak & & & & & & & & & + & & & & \\
\hline Anchistus custos & & & & & & & & & + & & & & \\
\hline Anchistus miersi & & + & & & & & & & & & & & \\
\hline Anchistus pectinis & & & & & & & & & + & & & & \\
\hline Climeniperaeus truncoideus & & & & & + & & & & & & & & \\
\hline Conchodytes biunguiculatus & & + & & & & & & & & & & & \\
\hline Conchodytes maculates & & & & & & & & & + & & & & \\
\hline Conchodytes meleagrinae & & & & + & & & & & + & + & & & \\
\hline Coralliocaris sp. & & & & & & & & & & + & & & \\
\hline Coralliocaris macrophthalma & & & & & & & & & + & & & & \\
\hline Coralliocaris superba & & + & & & & & & & + & & & & \\
\hline Coralliocaris viridis & & + & & & & & & & & & & & \\
\hline Dasycaris ceratops & & + & & & & & & & & & & & \\
\hline Dasycaris symbiotes & & & & & & & & & + & & & & \\
\hline Dasycaris zanzibarica & & + & & & & & & & & & & & \\
\hline Exoclimenella denticulate & & & & & & & & & & + & & & \\
\hline Exoclimenella cf. denticulate & & & & & & & & & & + & & & \\
\hline Exoclimenella maldivensis & & & & & & & & & & + & & & \\
\hline Hamodactylus boschmai & & & & & & & & & + & & & & \\
\hline Hamodactylus noumeae & & & & & & & & & + & & & & \\
\hline Hamopontonia corallicola & & & & & + & & & & & & & & \\
\hline Harpiliopsis beaupresii & & + & + & & & & & & & + & & & \\
\hline Harpiliopsis depressa & & & & & & & & & + & & & & \\
\hline Harpiliopsis spinigera & & & & & & & & & + & & & & \\
\hline Harpilius lutescens & & & & & & & & & & + & & & \\
\hline Ischnopontonia lophos & & + & & & & & & & & & & & \\
\hline focaste japonica & & & & & & & & & & + & & & \\
\hline focaste lucina & & & & & & & & & & + & & & \\
\hline Kemponia agag & & & & & & & & & + & & & & \\
\hline Kemponia amymone & & & & & & & & & + & & & & \\
\hline
\end{tabular}



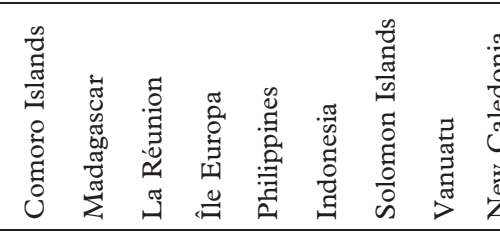

Kemponia anacanthus

Kemponia andamanensis

Kemponia darwiniensis

Kemponia elegans

Kemponia ensifrons

Kemponia grandis

Kemponia kororensis

Kemponia lacertae

Kemponia nilandensis

Kemponia seychellensis

Kemponia cf. suvadivensis

Kemponia tenuipes

Manipontonia psamathe

Mesopontonia brevicarpalis

Mesopontonia gracilicarpus

Metapontonia fungiacola

Palaemonella crosnieri

Palaemonella dolichodactylus

Palaemonella hachijo

Palaemonella komaii

Palaemonella pottsi

Palaemonella pusilla

Palaemonella rotumana

Palaemonella spinulata

Paraclimenes franklinae

Paranchistus nobilii

Paranchistus ornatus

Periclimenella petitthouarsi

Periclimenella spinifera

Periclimenes affinis

Periclimenes alcocki

Periclimenes aleator

Periclimenes amboinensis

Periclimenes attenuatus

Periclimenes brevicarpalis

Periclimenes brevirostris

Periclimenes calcaratus

Periclimenes ceratophthalmus

Periclimenes commensalis

Periclimenes cristimanus

Periclimenes crosnieri

Periclimenes forcipulatus

Periclimenes forgesi

Periclimenes foveolatus

Periclimenes hertwigi

Periclimenes imperator

Periclimenes incertus

Periclimenes involens

Periclimenes kempi Bruce, 1969

Periclimenes laccadivensis

Periclimenes lanipes

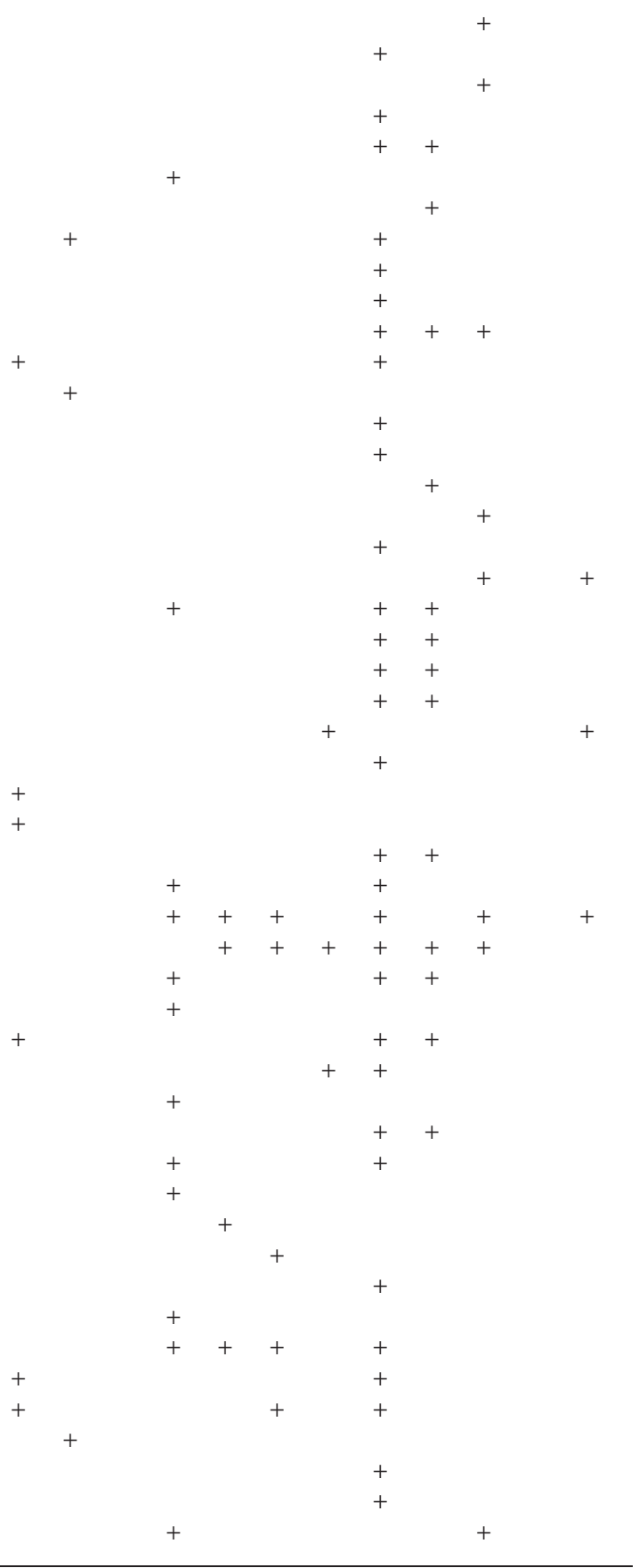




\begin{tabular}{|c|c|c|c|c|c|c|c|c|c|c|c|c|c|}
\hline & 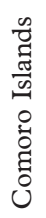 & 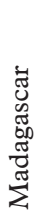 & 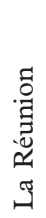 & 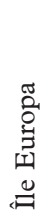 & 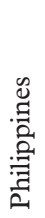 & 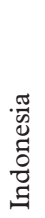 & 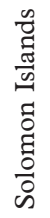 & $\begin{array}{c}\underset{J}{J} \\
\underset{\Xi}{\Xi} \\
\stackrel{\Xi}{J}\end{array}$ & 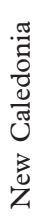 & 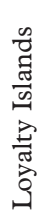 & 漓 & 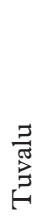 & 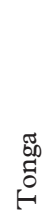 \\
\hline Periclimenes latipollex & & & & & & & & & + & & & & \\
\hline Periclimenes lepidus & & + & & & & & & & + & & & & \\
\hline Periclimenes loyautensis & & & & & & & & & & + & & & \\
\hline Periclimenes magnificus & & & & & & & & & + & & & & \\
\hline Periclimenes macrophthalmus & & & & & & & & & & & + & & \\
\hline Periclimenes novaecaledoniae & & & & & & & & & + & & & & \\
\hline Periclimenes paralcocki & & & & & & & & & & & & + & \\
\hline Periclimenes paraleator & & & & & & & & & + & & & & \\
\hline Periclimenes pilipes & & & & & + & & & & & & & & \\
\hline Periclimenes platyrhynchus & & & & & & & & & + & & & & \\
\hline Periclimenes pseudalcocki & & & & & & + & & & & & & & \\
\hline Periclimenes soror & & & & & & & & & + & + & & & \\
\hline Periclimenes tosaensis & & & & & & & & & & & + & & \\
\hline Periclimenes uniunguiculatus & + & & & & & & & & + & & & & \\
\hline Periclimenes vaubani & & & & & & & & & + & & & & \\
\hline Periclimenes venustus & & & & & & & & & + & & & & \\
\hline Periclimenes sp. & & & + & & & & & & & & & & \\
\hline Philarius imperialis & & & & & & & & & + & + & & & \\
\hline Platycaris latirostris & & + & & & & & & & & & & & \\
\hline Pliopontonia furtiva & & & & & & & & & + & & & & \\
\hline Pontoniopsis comanthi & & & & & + & & & & + & & & & \\
\hline Thaumastocaris streptopus & & & & & & & & & + & & & & \\
\hline Zenopontonia noverca & & + & & & & & & & + & & & & \\
\hline
\end{tabular}

